\title{
CHARACTERIZATION REPORT AREA 3 RADIOACTIVE WASTE MANAGEMENT SITE NEVADA TEST SITE, NEVADA
}

\author{
Prepared for \\ U.S. DEPARTMENT OF ENERGY \\ NATIONAL NUCLEAR SECURITY ADMINISTRATION \\ NEVADA SITE OFFICE

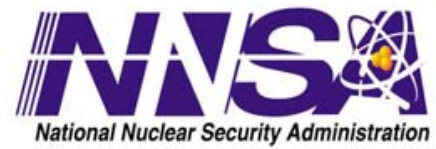 \\ Work Performed Under \\ Contract No. DE-AC52-06NA25946
}

Prepared By

National Security Technologies LLC

Las Vegas, Nevada

March 2007 


\section{DISCLAIMER}

Reference herein to any specific commercial product, process, or service by trade name, trade mark, manufacturer, or otherwise does not necessarily constitute or imply its endorsement, recommendation, or favoring by the United States Government or any agency thereof or its contractors or subcontractors.

Available for sale to the public, in paper, from:

U.S. Department of Commerce

National Technical Information Service

5285 Port Royal Road

Springfield, VA 22161

Phone: (800) 553-6847

Fax: (703) 605-6900

E-mail: orders@,ntis.gov

Online Ordering: http://www.ntis.gov/ordering.htm

Available electronically at http://www.osti.gov/bridge

Available for a processing fee to the U.S. Department of Energy and its contractors, in paper, from:

U.S. Department of Energy

Office of Scientific and Technical Information

P.O. Box 62

Oak Ridge, TN 37831-0062

Phone: (865) 576-8401

Fax: (865) 576-5728

E-mail: reports@adonis.osti.gov 


\title{
CHARACTERIZATION REPORT Area 3 Radioactive Waste Management Site Nevada Test Site, Nevada
}

\author{
Prepared for \\ U.S. DEPARTMENT OF ENERGY \\ NATIONAL NUCLEAR SECURITY ADMINISTRATION \\ NEVADA SITE OFFICE

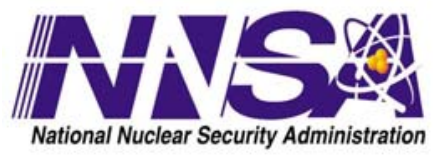 \\ Work Performed Under \\ Contract No. DE-AC52-06NA25946 \\ Prepared By \\ National Security Technologies LLC \\ Las Vegas, Nevada
}

March 2007 
This Page Intentionally Left Blank 
The U.S. Department of Energy (DOE), National Nuclear Security Administration Nevada Site Office (NNSA/NSO) operates the Area 3 Radioactive Waste Management Site (RWMS), a lowlevel waste disposal site located within Yucca Flat, on the Nevada Test Site, Nye County, Nevada. DOE developed the Area 3 RWMS in the middle of an active test area, within subsidence craters formed by underground nuclear experiments performed in the 1960s. The remote, restricted-access facility is located far from existing and anticipated development.

A portion of the Area 3 RWMS, the U-3ax/bl waste disposal cell, was closed in 2000 under a Resource Conservation and Recovery Act Interim Status permit. U-3ax/bl operated from 1968 to 1987 and may have received low-level mixed waste, as well as low-level waste. The open low-level waste disposal cells, U-3bh and U-3ah/at, are currently inactive. NNSA/NSO directed Bechtel Nevada to place the Area 3 RWMS on inactive status beginning July 1, 2006. The last shipment was received and buried in April 2006.

The Area 3 RWMS is scheduled to close in fiscal year 2008. The facility closure and post-closure maintenance and monitoring will be conducted in accordance with current DOE requirements.

This characterization report supports closure of the U-3bh and U-3ah/at waste disposal cells. The report identifies sources of site characterization, environmental monitoring, modeling studies and other information which describe the site setting, facility and waste characteristics, transport characteristics, and surrounding sources of contaminants. It includes pertinent information from the adjacent closed waste disposal cell, U-3ax/bl. This summary of the results of performance evaluations and other key characterization information supplements the 2005 Integrated Closure and Monitoring Plan for the Area 3 and Area 5 Radioactive Waste Management Sites at the Nevada Test Site; and the 2000 Performance Assessment/Composite Analysis for the Area 3 Radioactive Waste Management Site at the Nevada Test Site, Nye County, Nevada.

The data quality objectives required to define transport pathways and processes and to perform the Performance Assessment and Composite Analysis also effectively address the characterization data requirements for development of the closure plan. The data quality objectives are presented in referenced reports.

Although a few potential near-surface transport pathways were identified, they are not believed to affect the ability of the facility to meet DOE performance criteria. The nature of the waste; containers; physical and chemical properties of the thick, dry vadose zone; arid climate; and other factors mitigate potential downward transport of storm water and contaminants. Recharge is not likely to occur within the Area 3 RWMS during the 1,000-year compliance period. Adequate characterization data are available to design the final cover and develop the closure plan and post-closure monitoring plans. Experience gained from construction and management of the U-3ax/bl final closure cover can be applied to preparing the closure plan for the U-3bh and U-3ah/at waste disposal cells. 
This Page Intentionally Left Blank 
The U.S. Department of Energy (DOE), National Nuclear Security Administration Nevada Site Office (NNSA/NSO) manages two low-level radioactive waste management sites (RWMSs) at the Nevada Test Site (NTS). This report summarizes characterization and monitoring work pertinent to the Area 3 RWMS.

The Area 3 RWMS is located within Yucca Flat, a remote arid basin in the northeast part of the NTS. Researchers conducted hundreds of atmospheric and underground nuclear experiments at Yucca Flat between 1957 and 1992. DOE developed waste disposal cells within subsidence craters left by deep underground nuclear experiments performed in the 1960s. The Area 3 RWMS originally was created primarily to meet the bulk low-level waste (LLW) disposal needs of DOE facility demolition and soil remediation programs on and off the NTS. The Area 3 RWMS currently provides critical reserve LLW capacity and can accommodate bulky waste items. It is a fenced and bermed controlled-access facility.

DOE operated the oldest waste disposal cell, U-3ax/bl, from 1968 to 1987 and closed it in 2000 under a Resource Conservation and Recovery Act (RCRA) interim permit. U-3ax/bl primarily received bulk waste from the cleanup of experiment sites on the NTS. The closed waste disposal cell has a monolayer-ET cover of uncontaminated native soil, which has been revegetated with native plants to enhance evapotranspiration. The cover is instrumented with an automated vadose zone monitoring system to monitor infiltration and transport of moisture. Experience gained from construction and management of this final closure cover can be applied to closure plans for the active waste disposal cells.

Waste disposal cells U-3ah/at and U-3bh received unclassified LLW. Waste disposal records show that DOE developed U-3ah/at in 1987 and this waste disposal cell has received uncontained bulk soil, debris, and waste containers from NTS and off-site DOE generators. DOE developed U-3bh in 1997, primarily to dispose radiologically contaminated soil. Disposal records indicate that U-3bh has received both bulk LLW and packaged LLW. Both waste disposal cells are covered with monolayer operational covers of uncontaminated native soil.

Waste records for waste disposal cells U-3ah/at and U-3bh are relatively complete and detailed. These waste disposal cells began operation after the establishment of computerized database waste tracking systems. The waste records show that the waste disposal cells were developed after the promulgation of RCRA and received no low-level mixed waste (LLMW) or mixed waste. LLW operations and closure are regulated under DOE Orders. The projected inventory of the U-3ah/at and U-3bh waste disposal cells at closure will have an activity that is less than 3 percent of the maximum permitted under the performance objectives of DOE Order 435.1.

The Area 5 RWMS is currently the main LLW disposal site at the NTS and has adequate capacity to handle most of the anticipated LLW waste streams at the NTS in the near future. The Area 3 RWMS provides critical reserve capacity and can accommodate large bulk waste items. The most recent waste load delivered to the Area 3 RWMS was disposed on April 19, 2006. NNSA/NSO placed the Area 3 RWMS on inactive status beginning July 1, 2006.

Routine monitoring of the NTS and site-specific monitoring systems at the two RWMS facilities have provided abundant documentation of environmental site conditions and the performance of existing monolayer-ET soil landfill covers. The data fulfill requirements of DOE orders and U.S. 
Environmental Protection Agency regulations and provide early warning of potential containment problems. The meteorological, radiation, and vadose zone monitoring in particular, provide critical data required for performance assessments and contaminant transport models. After final closure of the facility, the monitoring needs and program will be updated and modified as needed through the maintenance of the Area 3 Performance Assessment (PA) and Composite Analysis (CA). These assessments and analyses demonstrate compliance with performance objectives defined by DOE orders.

The Area 3 RWMS site setting and physical characteristics are well documented. General studies of the NTS, investigations of the impacts of past nuclear experiments, and site-specific characterization work provide ample data for evaluation of the performance of the facility and for design and development of an appropriate closure plan. This report presents brief summaries of regional and site-specific characteristics by topic, and a very brief summary of some of the performance modeling results pertinent to the development of closure plans. The reader is referred to the original studies and data sources for the data quality objectives, methods, limitations, and detailed analysis of results. The data quality objectives for the data required to define transport pathways and processes and perform the PA/CA effectively address data requirements for development of a closure plan.

The Area 3 RWMS is within a nuclear test area. The facility is surrounded and underlain by residual radiological contaminants from historic atmospheric and underground experiments. Monitoring and conservative performance assessment analyses demonstrate that the landfill operations have not added to the ambient man-made and natural radiation, and are very unlikely to fail DOE performance criteria designed to protect the public and environment. The surrounding sources have been included in composite analysis evaluation of potential future exposures. The CA demonstrates that waste operations at the Area 3 RWMS are expected to meet the current DOE composite analysis performance criteria throughout the 1,000-year post-closure compliance period.

The remote and arid setting of the Area 3 RWMS is well-suited for the isolation and disposal of radioactive waste. The site is far from permanent residential areas. The nearest community is about 57 kilometers (km) (35 miles [mi]) to the southwest in Amargosa Valley. Population densities near the site are low. Although population growth in southern Nevada is rapid, the location of growth is constrained by the availability of land for development. All of the land immediately bordering the NTS is under federal control. Access to the Nevada Test and Training Range, which borders three sides of the NTS, is very limited. The Bureau of Land Management manages land bordering the south edge of the NTS. Future development is also constrained by the availability of potable water supplies, and the cost to tap deep groundwater aquifers.

Potential for significant transport or release of contaminants from the waste deposits are mitigated by waste characteristics, packaging, soil cover characteristics, depth of waste burial, shallow plant-rooting depths, great depth to groundwater, properties of the unsaturated zone, lack of significant surface runoff, flood mitigation berms, low precipitation rates, high evapotranspiration rates, alkaline soils, and low risk of damage from natural hazards.

The arid climate processes and the thick and dry vadose zone effectively provide a natural containment barrier. There is no permanent surface water near the site. The potential for storm 
water transport into and through the waste and for rapid transport of contaminants through the vadose zone is low. Groundwater is not a viable pathway for future exposure to contaminants from the landfill.

Yucca Flat is a closed sub-basin with no surface water outflows and is in one of the most arid regions of the United States. Average annual total rainfall based on the 1961 to 2004 period of record at the Air Resources Laboratory meteorology station Buster-Jangle Y, about $4.5 \mathrm{~km}$ (2.8 $\mathrm{mi}$ ) from the Area $3 \mathrm{RWMS}$, is only 163.8 millimeters (6.45 inches). Annual total potential evapotranspiration (PET) far exceeds precipitation. Even in 2004, a wet year with aboveaverage total precipitation, PET was approximately six times greater than total annual precipitation at the Area 3 RWMS. On a seasonal and daily basis, there are significant variations in the factors affecting the near-surface alluvium water balance, but most of the precipitation that infiltrates the alluvium is evapotranspired back to the atmosphere. In the current climate, water rarely reaches downward past the rooting depth of native plants. Analyses of samples from soil borings indicate the matric potential gradient of the uppermost 50 meters $(\mathrm{m})(160 \mathrm{feet}[\mathrm{ft}])$ of undisturbed alluvium is upward. The Area $3 \mathrm{RWMS}$ is underlain by about $300 \mathrm{~m}(1,000 \mathrm{ft})$ of dry alluvium, underlain by volcanic tuff. The uppermost aquifer is in the volcanic tuff. Depth to groundwater is at least $488 \mathrm{~m}(1,600 \mathrm{ft})$.

There is no regulatory groundwater monitoring requirement for LLW disposal cells. For the closed U-3ax/bl LLMW cell, the Nevada Division of Environmental Protection approved an exemption from Title 40 Code of Federal Regulations (CFR) 265.310, "Groundwater Monitoring." The approved RCRA permit application contains a detailed monitoring waiver petition meeting Title 40 CFR 265.90 (c). The basis for the exemption is the low potential for leachate to form and reach groundwater.

Hydrological transport modeling for the PA/CA shows that recharge to groundwater in the vicinity of the landfill is improbable, even if the climate were to become significantly less arid. The landfill cover is expected to subside in the distant future which would allow water to pond on the landfill cover after large precipitation events. Even if the resulting soil moisture levels become sufficient to permit gravitational movement of water downward through the soil cover and into the waste, potential radionuclide solute travel times through the thick vadose zone with ample potential storage would be slow. Consequently, it is unlikely that the water and contaminants will reach the groundwater within the 1,000-year compliance period.

There are no natural surface waters near the site and the flood-hazard potential is low. The site is outside of the 100-year flood zone as defined by the Federal Emergency Management Agency methods. The potential for future volcanic activity is very low. The youngest volcanic outcrop in the area is the Lathrop Wells basalt, which erupted about 80,000 years ago and is located southwest of the NTS. The potential for seismic activity is greater, but the likelihood of earthquakes impacting the structural integrity or drainage characteristics of the landfill facility is small. Some erosion and subsidence of the cover surface is expected over time as waste materials and the native soil cover compact. The use of a single layer cover helps mitigate potential failure and movements along cover layers. Current waste emplacement strategies take into consideration minimizing voids between containers and reducing future potential differential settling.

In the 1,000-year post-closure compliance period, the most likely routes of human and environmental exposure to radionuclides at the Area 3 RWMS include potential movement of 
solutes and vapor up through the cover, and inadvertent human intrusions. Inadvertent human intrusions may occur after active institutional control ends; administrative controls such as use restrictions fail; and on-site monuments and signs are damaged, removed, or obscured. Transport of soluble radionuclides by liquid advection, diffusion, and biotic activities are likely processes for movement of contaminants up through the cover. The biotic transport model and our understanding of the potential for biotic transport of contaminants through soil landfill cover at the NTS have been greatly enhanced by recent characterization studies of vegetal and animal communities, rooting characteristics, plant uptake, and animal burrowing habits. The new information has been incorporated in probabilistic models for analysis of facility performance, and will be considered in establishment of design criteria for the final closure covers for the active landfill cells.

The limited availability of private developable land; the scarcity of water supplies; the presence of residual contamination from past nuclear testing activities; and the anticipated ongoing use of the Yucca Flat part of the NTS for a wide variety of testing, training, and industrial activities reduces the likelihood of substantial residential and commercial development near the Area 3 RWMS. Conservative scenarios of future disturbance of the waste and habitation of the waste site are included in the PA/CA of the facility.

Review of site characterization data indicate that there may be potential preferred transport routes in the uppermost part of the vadose zone, including a few historically mapped lineaments representing surface fractures caused by underground tests, and potentially unplugged (but most likely capped) boreholes below waste disposal cells. The presence of these potential nearsurface transport pathways is unlikely to significantly change the conclusions of the PA/CA of the Area 3 RWMS waste operations because the site setting, site climate, characteristics of the waste, characteristics of the hydrostratigraphy, and other factors provide very significant barriers to the release and dispersion of radionuclides within the waste.

The surface fractures in unconsolidated alluvium are not expected to propagate to significant depths below ground surface. It is likely that these surface features have been obscured by fracture healing processes and over 40 years of surface erosion and deposition since these features were observed and mapped.

The condition and plugging status of some preexisting postshot nuclear test investigation boreholes (drilled in the upper vadose zone within the subsidence craters and subsequently buried with waste) are unknown. However, further site assessments are not warranted because the nature of the waste, containers, arid climate, alkaline soils, and other factors constrain potential mobilization of contaminants.

Currently, NNSA/NSO anticipates completing closure of the Area 3 RWMS in fiscal year 2008. Closure schedule plans may change to accommodate changes in funding and federal program needs.

Closure will be conducted in accordance with DOE Order 435.1. Ample existing characterization and performance analysis documentation are available for the development of a closure plan, the design of the final landfill cover, and the post-closure monitoring plan. Ongoing monitoring programs and studies will support updated performance evaluations. 


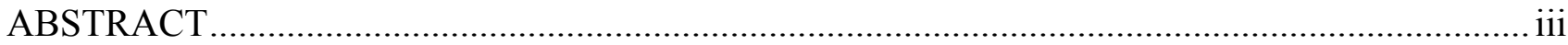

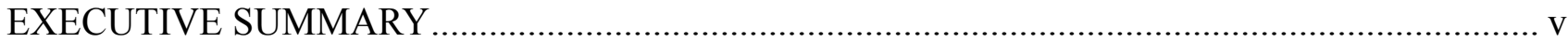

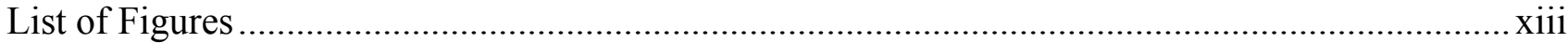

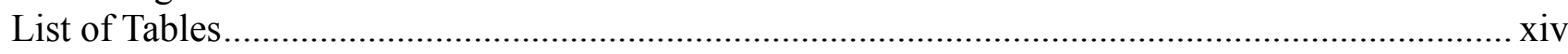

ACRONYMS and ABBREVIATIONS ............................................................................

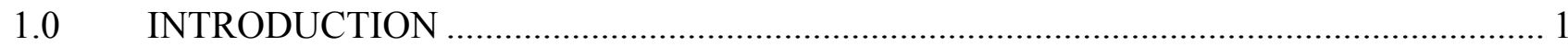

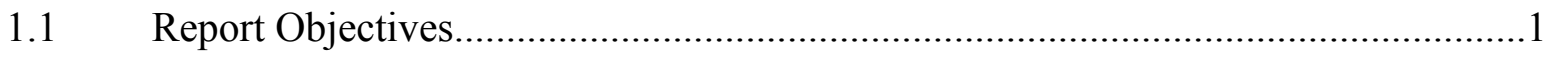

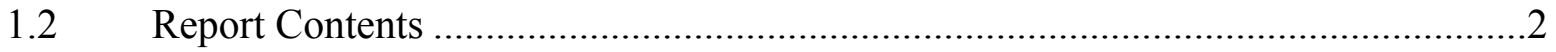

2.0 SITE LOCATION AND SETTING ................................................................... 3

2.1 Geography, Land Use, and Demographics ................................................. 3

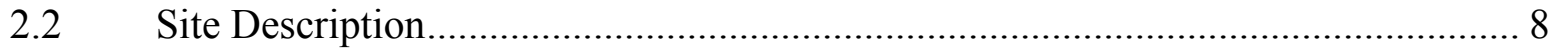

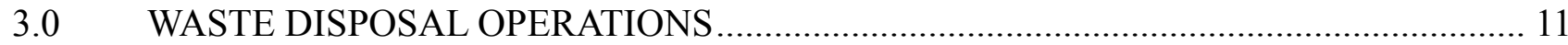

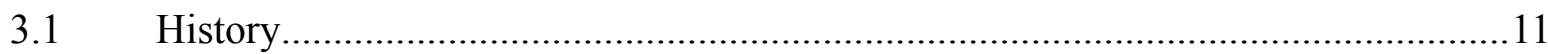

W.2 Waste Types and Acceptance Criteria ...........................................................12

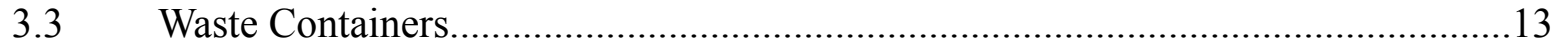

W.4 Waste Placement and Operational Covers .....................................................13

W.5 Waste Tracking....................................................................................... 13

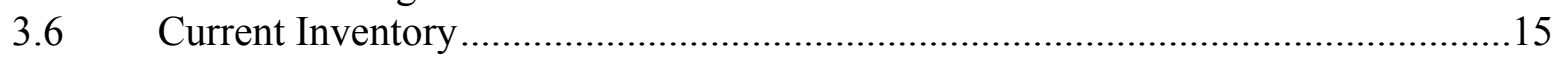

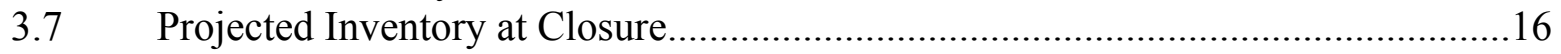

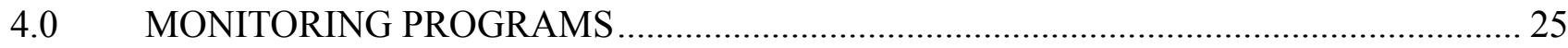

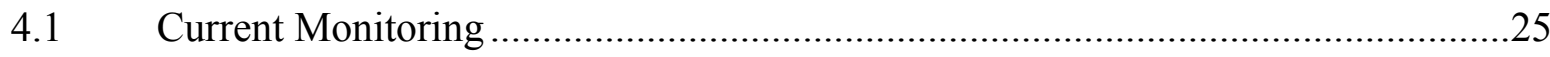

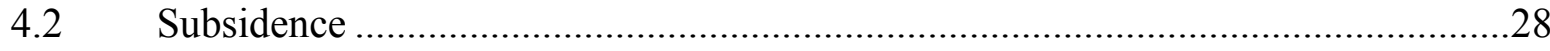

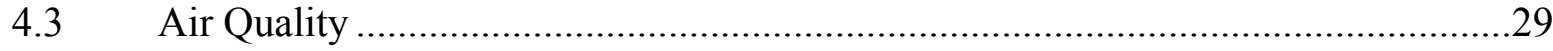

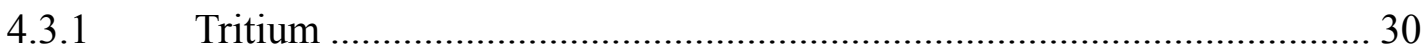

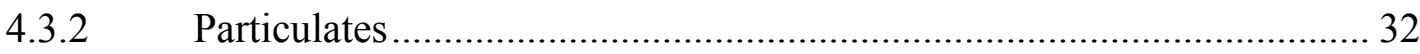

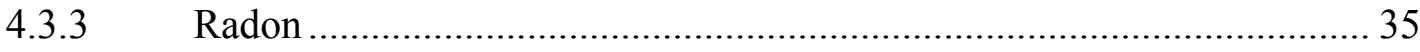

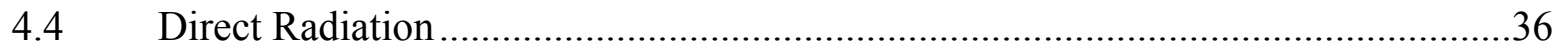

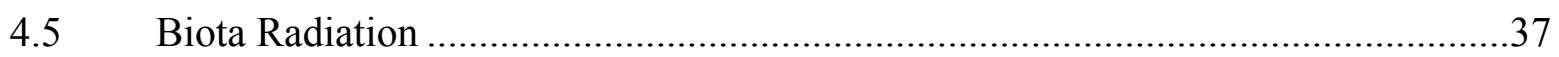

$5.0 \quad$ NEARBY RADIOLOGICALLY IMPACTED SITES .............................................41 
6.1 Hydrologic Conceptual Model for the Area 3 RWMS...............................................47

6.2 Performance Assessment and Composite Analysis..................................................51

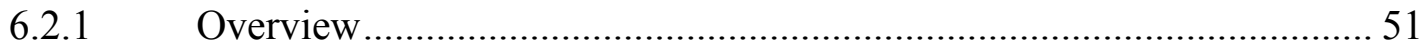

6.2.2 General Assumptions and Performance Objectives................................ 52

6.2.3 General Results ................................................................................. 53

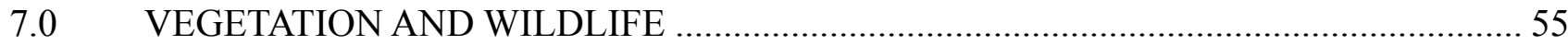

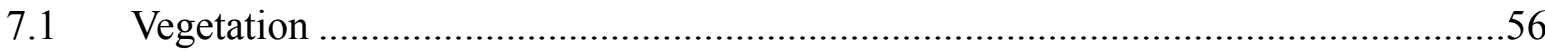

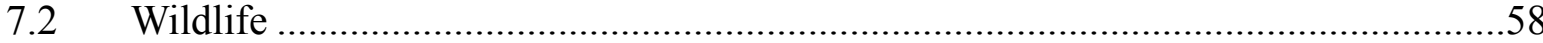

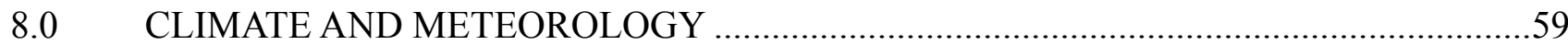

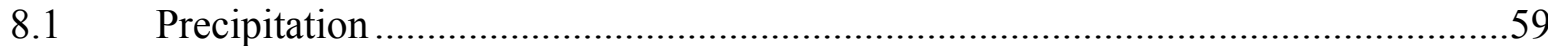

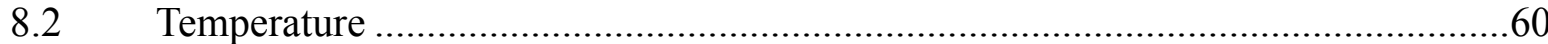

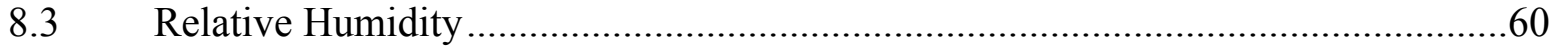

$8.4 \quad$ Potential Evapotranspiration..........................................................................60

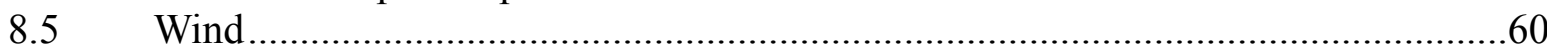

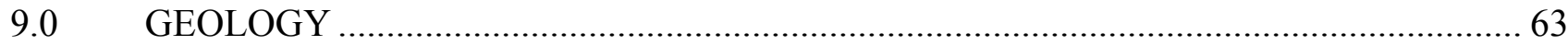

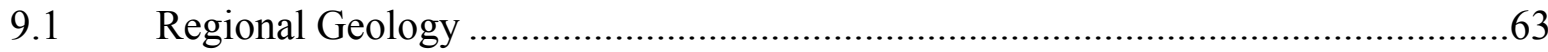

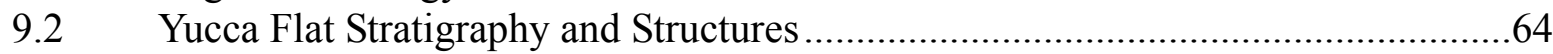

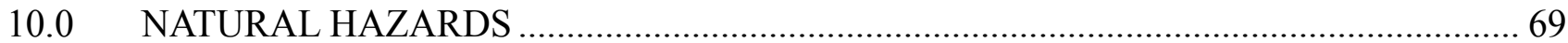

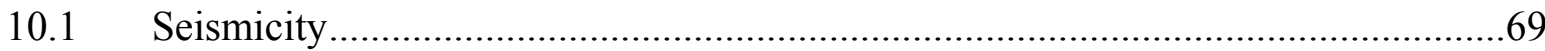

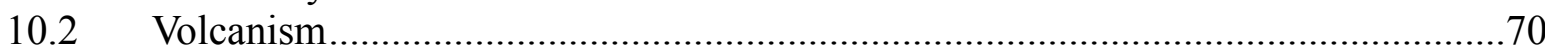

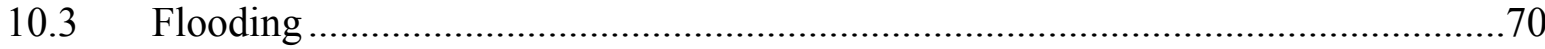

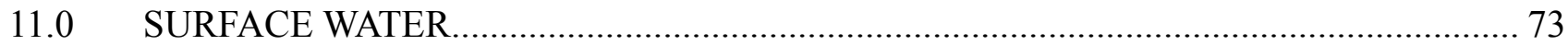

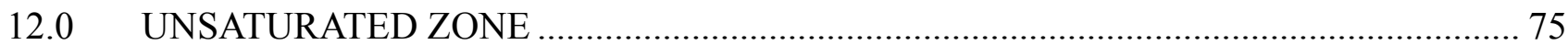

12.1 Hydrogeologic Characterization Study ………….............................................

12.1.1 Particle Size Distribution and Soil Classification................................... 80

12.1.2 Mineral Composition, Geochemistry, and Cation Exchange

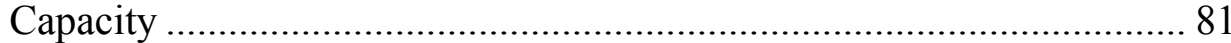

12.1.3 Water Content (Soil Moisture) ..................................................... 82

12.1.4 Water Potential, Water Characteristic Curves, and Unsaturated

Hydraulic Conductivity ...................................................................... 82 


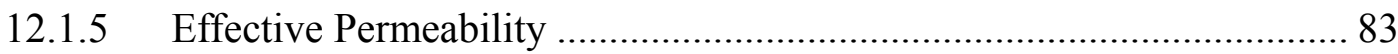

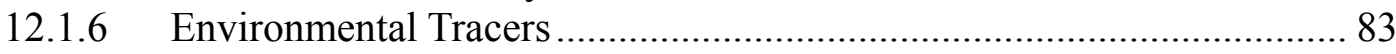

12.1.7 Chemical and Radiological Contaminants ............................................. 84

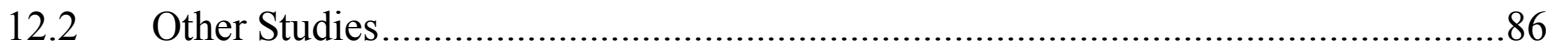

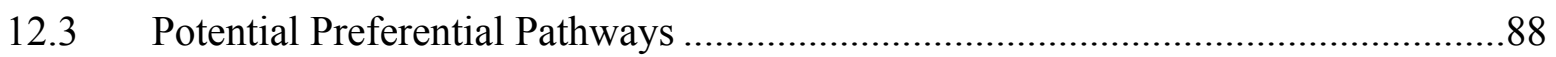

12.4 Water Balance Monitoring and Cover Performance ................................................91

12.4.1 Automated Waste Cover Monitoring System ..................................... 91

12.4.2 Lysimeter Facilities ........................................................................... 92

12.4.3 Conclusions ................................................................................... 93

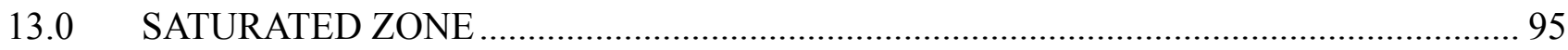

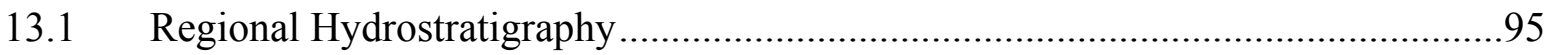

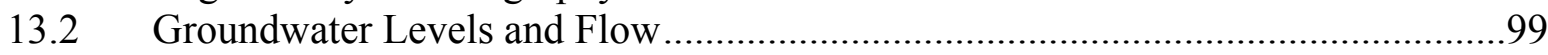

13.3 Groundwater Chemistry ...............................................................................103

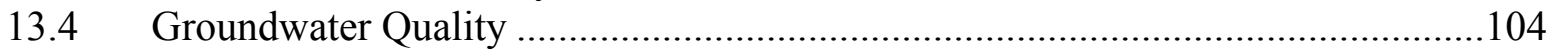

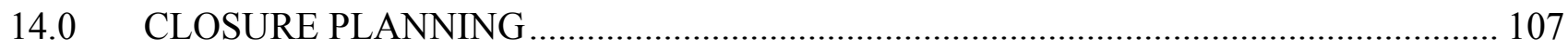

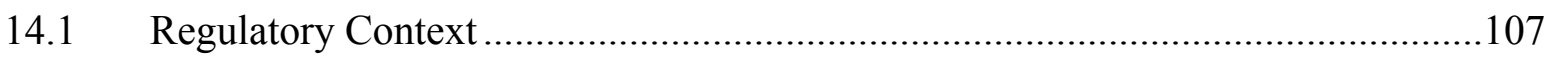

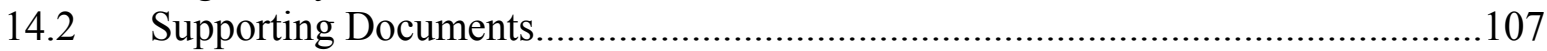

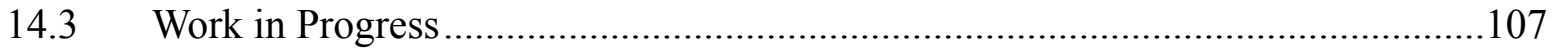

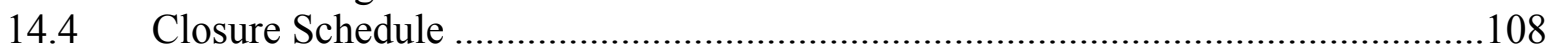

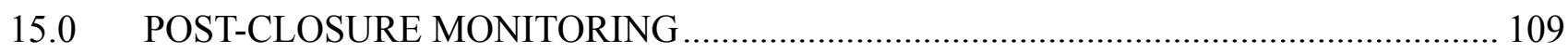

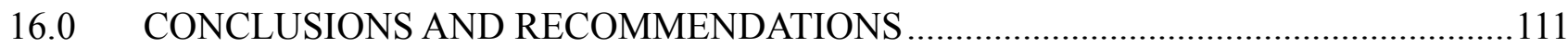

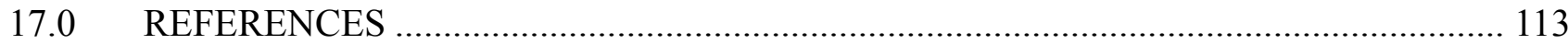

Appendix A Annotated Bibliography of Selected References Relevant to the Area 3

Radioactive Waste Management Site ................................................................... A-1

Appendix B Groundwater Quality Data ............................................................................... B-1

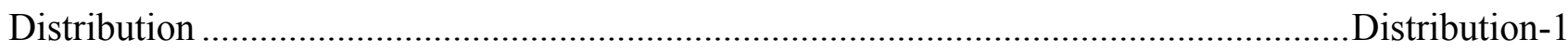


This Page Intentionally Left Blank 


\section{List of Figures}

Figure $1 \quad$ Location Map ......................................................................................... 4

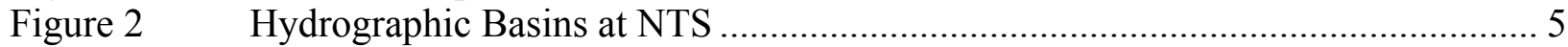

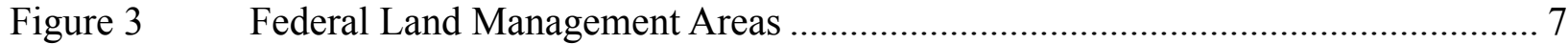

Figure 4 Area 3 Radioactive Waste Management Site ................................................... 9

Figure $5 \quad$ Monitoring Stations at the Area 3 RWMS ................................................... 26

Figure 6 Time-Domain Reflectometry Nests and Subsidence Monitoring

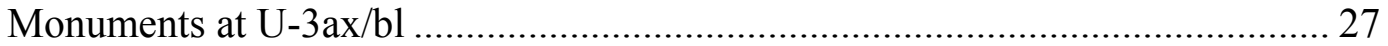

Figure $8 \quad$ Highest Annual Mean Plutonium in Air Samples ............................................. 33

Figure 9 Average Trends Plutonium in Air Samples..................................................... 34

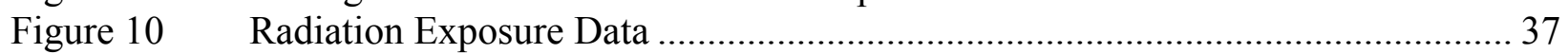

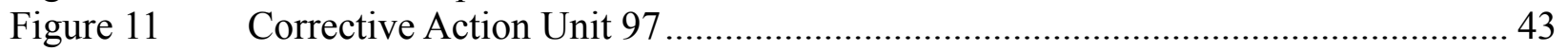

Figure 12 Simplified Cross-Section of the Area 3 RWMS ............................................. 45

Figure 13 Vadose Zone Hydrologic Conceptual Model of the Area 3 Radioactive

Waste Management Site............................................................................... 49

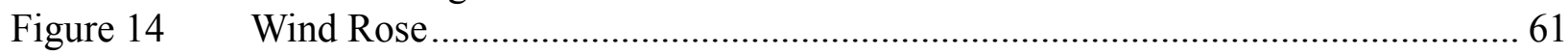

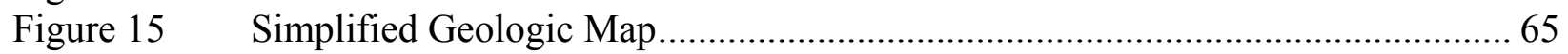

Figure $16 \quad$ Simplified Stratigraphic Section of Yucca Flat ............................................. 67

Figure 17 Stratigraphic Cross-Section of Yucca Flat, West-East through

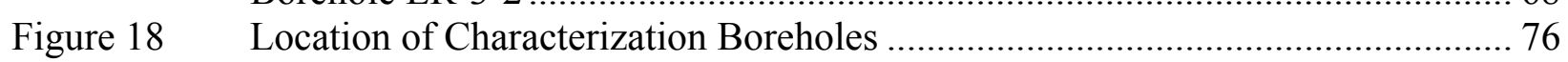

Figure 19 Location of U-3bl-D2 Borehole With Respect to Idealized Collapse

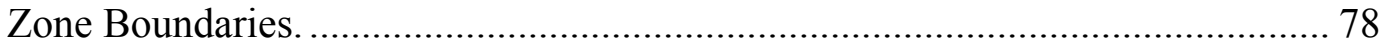

Figure $20 \quad$ Status of Boreholes in the Area 3 RWMS as of April 10, 2006....................... 90

Figure $21 \quad$ USGS Environmental Restoration Program Monitoring Well Locations ............ 96

Figure 22 West-East Cross-Section of Area 3 RWMS Showing Hydrostratigraphic Units and Faults ........................................................................................... 98

Figure 23 Regional Groundwater Flow and Discharge Areas..................................... 102 


\section{List of Tables}

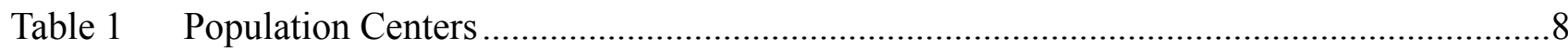

Table 2 Waste Disposal Records through July 2006................................................................16

Table 3 Closure Inventory Estimate for the U-3ax/bl Disposal Cell ..............................................17

Table 4 Closure Inventory Estimate for the U-3ah/at Disposal Cell Projected from Inventory Data through FY 2005 ............................................................19

Table 5 Closure Inventory Estimate for the U-3bh Disposal Cell Projected from Inventory Data through FY 2005 ............................................................22

Table 6 Tritium 2004 Mean Analytical Results .........................................................................

Table 7 Radioactive Particulates 2004 Mean Analytical Results ....................................................35

Table 8 Composite Biota Samples Collected from U-3ax/bl........................................................40

Table 9 FFACO CAU 97 Corrective Action Sites within the Area 3 RWMS .................................44

Table 10 Performance Objectives and Results of the Area 3 RWMS Performance

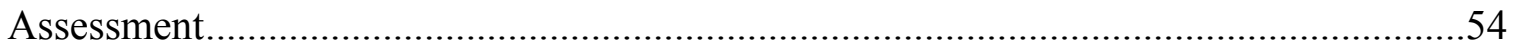

Table 11 Area 3 RWMS Characterization Boreholes ………………………………....................77

Table 12 Physical and Hydraulic Properties of Area 3 RWMS Characterization Samples ...............79

Table 13 Summary of Hydrologic Properties for Hydrogeologic Units in

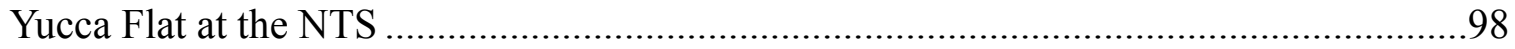

Table 14 Depth to Groundwater at Several Wells in Area 3 of the NTS .......................................100 


\section{ACRONYMS and ABBREVIATIONS}

\begin{tabular}{|c|c|}
\hline $\begin{array}{l}\text { ALARA } \\
\text { amsl }\end{array}$ & $\begin{array}{l}\text { as low as reasonably achievable } \\
\text { above mean sea level }\end{array}$ \\
\hline ARL/SORD & Air Resource Laboratory, Special Operations and Research Division \\
\hline ASER & Annual Site Environmental Report \\
\hline $\begin{array}{l}\text { BEIDMS } \\
\text { bgs } \\
\text { BJY } \\
\text { BN }\end{array}$ & $\begin{array}{l}\text { Bechtel Environmental Integrated Data Management System } \\
\text { below ground surface } \\
\text { Buster-Jangle Y } \\
\text { Bechtel Nevada }\end{array}$ \\
\hline${ }^{\circ} \mathrm{C}$ & degrees Celsius \\
\hline CA & Composite Analysis \\
\hline CADD & Corrective Action Decision Document \\
\hline CAIP & Corrective Action Investigation Plan \\
\hline CAS & Corrective Action Site \\
\hline CAU & Corrective Action Unit \\
\hline $\mathrm{CEC}$ & cation exchange capacity \\
\hline CFR & Code of Federal Regulations \\
\hline $\mathrm{Ci}$ & curie(s) \\
\hline $\mathrm{CL}$ & concentration level \\
\hline $\mathrm{cm}$ & centimeter(s) \\
\hline DAS & Disposal Authorization Statement \\
\hline DOE & U.S. Department of Energy \\
\hline DRI & Desert Research Institute \\
\hline EPA & U.S. Environmental Protection Agency \\
\hline ET & evapotranspirative; evapotranspiration \\
\hline${ }^{\circ} \mathrm{F}$ & degrees Fahrenheit \\
\hline FEMA & Federal Emergency Management Agency \\
\hline FFACO & Federal Facility Agreement and Consent Order \\
\hline $\mathrm{ft}$ & feet \\
\hline $\mathrm{ft}^{3}$ & cubic feet \\
\hline FY & fiscal year \\
\hline HRMP & Hydrologic Resources Management Program \\
\hline HQ & headquarters \\
\hline $\begin{array}{l}\text { ICMP } \\
\text { in. }\end{array}$ & $\begin{array}{l}\text { Integrated Closure and Monitoring Plan } \\
\text { inch }(s)\end{array}$ \\
\hline $\mathrm{km}$ & kilometers \\
\hline $\mathrm{km} / \mathrm{hr}$ & kilometers per hour \\
\hline $\mathrm{km}^{2}$ & square kilometers \\
\hline
\end{tabular}




\begin{tabular}{|c|c|}
\hline LANL & Los Alamos National Laboratory \\
\hline LCA & Lower Carbonate Aquifer \\
\hline $\mathrm{LCCU}$ & Lower Clastic Confining Unit \\
\hline LLMW & low-level mixed waste \\
\hline LLNL & Lawrence Livermore National Laboratory \\
\hline LLW & Low-Level Waste \\
\hline LWIS & Low-Level Waste Information System \\
\hline $\mathrm{m}$ & meter(s) \\
\hline $\mathrm{m}^{3}$ & cubic meter(s) \\
\hline Мa & million years ago \\
\hline MEDA & Meteorological Data Acquisition Stations \\
\hline & mile(s) \\
\hline $\mathrm{mi}^{2}$ & square miles \\
\hline $\mathrm{m}^{3} / \mathrm{m}^{3}$ & cubic meter per cubic meter \\
\hline $\mathrm{mm}$ & millimeter \\
\hline $\mathrm{M} \& \mathrm{O}$ & Management and Operations \\
\hline $\mathrm{mph}$ & miles per hour \\
\hline $\mathrm{mR} /$ day & milliroentgens per day \\
\hline $\mathrm{mrem} / \mathrm{yr}$ & milligrams per year \\
\hline $\mathrm{m} / \mathrm{s}$ & meters per second \\
\hline$\mu \mathrm{Ci} / \mathrm{ml}$ & microCuries per milliliter \\
\hline NESHAP & National Emissions Standards for Hazardous Air Pollutants \\
\hline NDEP & Nevada Division of Environmental Protection \\
\hline NNSA/NSO & $\begin{array}{l}\text { U.S. Department of Energy, National Nuclear Security Administration } \\
\text { Nevada Site Office }\end{array}$ \\
\hline NTS & Nevada Test Site \\
\hline NTSER & Nevada Test Site Environmental Report \\
\hline NTSWAC & Nevada Test Site Waste Acceptance Criteria \\
\hline $\mathrm{pCi} / \mathrm{m}^{2} / \mathrm{s}$ & picoCurie(s) per square meter per second \\
\hline $\mathrm{pCi} / \mathrm{L}$ & picoCurie(s) per liter \\
\hline PA & Performance Assessment \\
\hline PET & potential evapotranspiration \\
\hline REECo & Reynolds Electrical \& Engineering Co., Inc. \\
\hline RCRA & Resource Conservation and Recovery Act \\
\hline RREMP & Routine Radiological Environmental Monitoring Plan \\
\hline RWMS & Radioactive Waste Management Site \\
\hline SD & standard deviation \\
\hline TLD & thermoluminescent dosimeter \\
\hline TDR & time-domain reflectometry \\
\hline TEDE & total effective dose equivalent \\
\hline
\end{tabular}


ACRONYMS and ABBREVIATIONS (continued)

UGTA Underground Test Area

USGS U.S. Geological Survey

VOC volatile organic compound

WMMR Waste Management Monitoring Report 
This Page Intentionally Left Blank 


\section{$1.0 \quad$ INTRODUCTION}

The U.S. Department of Energy (DOE), National Nuclear Security Administration Nevada Site Office (NNSA/NSO) manages the Area 3 Radioactive Waste Management Site (RWMS). The Area 3 RWMS was originally created primarily to meet the bulk disposal needs of DOE facility demolition and soil remediation programs on and off the Nevada Test Site (NTS). The Area 3 RWMS now provides reserve low-level radioactive waste (LLW) capacity and can also accommodate large bulk LLW (Bechtel Nevada [BN], 2005i). The Area 3 RWMS is comprised of landfill cells established in a group of shallow collapse sinks in the Yucca Flat basin. The landfill cells are designated U-3ax/bl, U-3ah/at, and U-3bh. The collapse sinks, often referred to as subsidence "craters," were formed by the collapse of deep underground test cavities after nuclear experiment detonations in the early 1960s. The void space moved up to ground surface leaving a subsidence "crater" at ground surface.

A portion of the Area 3 RWMS facility, the U-3ax/bl waste disposal cell, was closed in 2000. The NNSA/NSO placed the other cells on inactive status effective July 1, 2006. NNSA/NSO anticipates closing the U-3bh and U-3ah/at cells of the Area 3 RWMS in 2008. This characterization report identifies sources of characterization, environmental monitoring and modeling data pertinent to closure planning for the Area 3 RWMS, and briefly summarizes key results. The focus is on U-3bh and U-3ah/at, but pertinent information from the characterization and closure of the adjacent, closed $\mathrm{U}-3 \mathrm{ax} / \mathrm{bl}$ cell is included.

Over the past several decades, the Area 3 RWMS and the vicinity have been well-studied. Environmental monitoring programs have been implemented to meet multiple DOE program needs. RWMS site-specific studies have been performed to characterize the upper vadose zone, assess the characteristics of the disturbed alluvium in the test collapse chimneys below the landfill cells, evaluate the potential for fault displacements, analyze allostratigraphic units and fractures, and investigate other features with suspected potential for providing pathways for water and contaminants through the vadose zone. Investigations of the underground test areas have improved the understanding of the region's complex hydrostratigraphy, which will help in the development of regional groundwater flow and contaminant transport models. The corrective action investigations and studies of transport processes being done to address residual contamination from decades of past nuclear testing in the Yucca Flat region also provide data relevant to evaluating the performance of the Area 3 RWMS facility. Numerous documents prepared by NNSA/NSO, the national laboratories, U.S. Geological Survey (USGS), U.S. Environmental Protection Agency (EPA), NNSA/NSO contractors, and other researchers present characteristics pertinent to potential contaminant transport and landfill containment performance. This information can be used to support development of a closure plan for the landfill cells.

\section{$1.1 \quad$ Report Objectives}

This Characterization Report has been prepared for NNSA/NSO to summarize characterization and monitoring data pertinent to the closure of the U-3ah/at and U-3bh waste disposal cells at the Area 3 RWMS. BN (1999b) addressed characterization of the closed U-3ax/bl waste disposal cell. 
This report summarizes data required to support the development of a conceptual model and closure strategy. Quality assurance and quality control data, more detailed analyses, and further discussion are presented in the cited reports.

\section{$1.2 \quad$ Report Contents}

The report is organized as follows:

1.0 Introduction (location of site and purpose of document)

2.0 Site Location and Setting

3.0 Waste Disposal Operations (history, general practices, and waste inventory)

4.0 Monitoring Programs

5.0 Nearby Radiologically Impacted Sites

6.0 Conceptual Models and Assessments (contaminant transport performance models and projections)

7.0 Vegetation and Wildlife

8.0 Climate and Meteorology

9.0 Geology

10.0 Natural Hazards

11.0 Surface Water

12.0 Unsaturated Zone

13.0 Saturated Zone

14.0 Closure Planning

15.0 Post-Closure Monitoring

16.0 Conclusions and Recommendations

17.0 References

Appendix A provides a brief bibliography of selected references.

Appendix B provides regional groundwater quality data. 


\subsection{SITE LOCATION AND SETTING}

The Area 3 RWMS is a bulk LLW disposal site located within the NTS, an approximately 3,560-square-kilometer $\left(\mathrm{km}^{2}\right)\left(1,375\right.$-square-mile [ $\left.\left.\mathrm{mi}^{2}\right]\right)$ federal research and training facility operated by the DOE (Figure 1). The Area 3 RWMS is in a remote rural area northwest of Las Vegas, Nevada. The Nevada Test and Training Range borders the north, east, and west edges of the NTS. Public access is restricted at both the NTS and the Nevada Test and Training Range.

\subsection{Geography, Land Use, and Demographics}

The remote and arid setting of the Area 3 RWMS at the NTS is well-suited for the isolation and disposal of radioactive waste. The NTS is in the Basin and Range Physiographic Province, which is characterized by fault block-bounded, alluvium-filled basins between north-southtrending mountain ranges. The Area 3 RWMS is within the Yucca Flat hydrographic basin, a sub-basin of the Great Basin (see Figure 2). The Yucca Flat basin extends approximately 27 kilometers $(\mathrm{km})(17 \mathrm{miles}$ [mi]) by $16 \mathrm{~km}$ (10 mi) and is bounded by Quartzite Ridge and Rainer Mesa on the north, the Halfpint Range on the east, the Massachusetts Mountains and CP Hills on the south, and by Mine Mountain and the Eleana Range on the west. The elevation of Yucca Flat ranges from about 1,402 meters $(\mathrm{m})(4,600$ feet [ft]) above mean sea level (amsl) at the north end of the basin to $1,189 \mathrm{~m}(3,900 \mathrm{ft})$ amsl at the playa at the lowest part of the basin. The Area 3 RWMS elevation is approximately 1,223 m (4,012 ft) (BN, 2005d).

The natural topography of the Area 3 RWMS has been altered by subsidence craters from nuclear testing and the use of these craters for waste disposal. Subsidence craters from underground tests, residual surface soil contamination from atmospheric tests, and the cost of obtaining a reliable water supply may limit future land use-options.

Restricted areas controlled by the U.S. Air Force bound the NTS to the north, east, and west. These contiguous federal restricted areas encompass approximately $14,200 \mathrm{~km}^{2}\left(5,483 \mathrm{mi}^{2}\right)$ of land. The Area 3 RWMS is within a zone of the NTS designated by the DOE for nuclear and high-explosive tests (DOE, 1996a). There are no permanent long-term residential areas at NTS facilities. The Mercury support complex is located in the southeast corner of the NTS, about 45 linear km (28 mi) from the Area 3 RWMS.

In 1951, when Yucca and Frenchman Flats were transferred to the Atomic Energy Commission from the Las Vegas Army Air Field for use as the primary continental site for nuclear testing, the southwestern United States was very sparsely populated. In 1950, Nevada ranked 50th in population size among the 50 existing and future states (Alaska and Hawaii became states in 1959) (U.S. Census Bureau, 2002b). Nevada is still relatively sparsely populated compared to most of the United States. In 2000, Nevada ranked 35th in total state population. Average population density in Nevada was 18.2 per square mile, compared to the national average of 79.6 per square mile (U.S. Census Bureau, 2002b). 


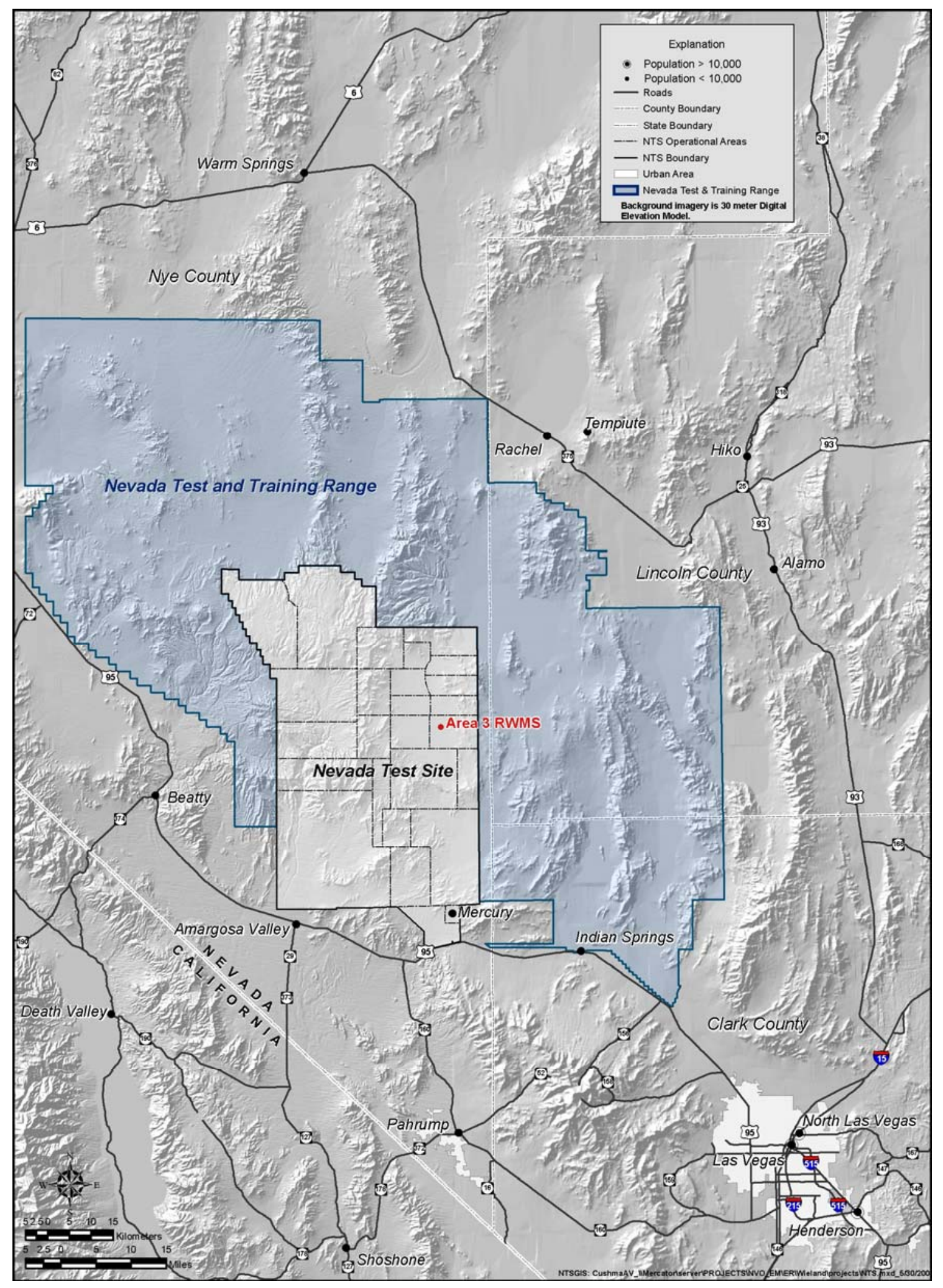

Figure 1

Location Map 


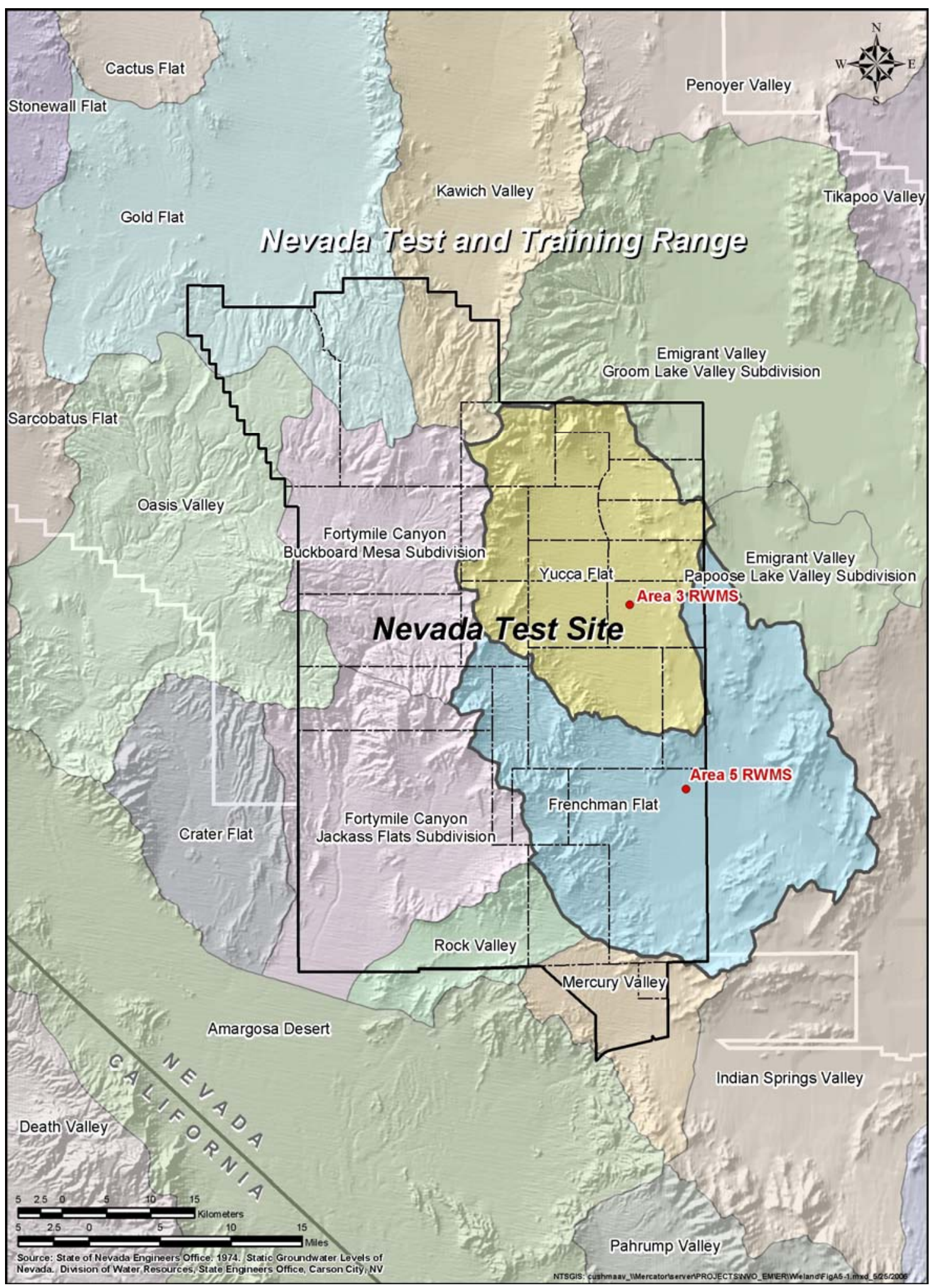

Figure 2

Hydrographic Basins at NTS 
Although Nevada's population is growing rapidly, the population continues to be concentrated in a few urban areas associated with readily available water supplies, and/or significant economic resources. The population distribution and potential for future residential growth is also significantly constrained by the limited availability of private land. In 2001, only about 11.5 percent of Nevada was private land. Approximately 86.1 percent of the state of Nevada was federally managed, 1.6 percent was Tribal Land held in trust by the federal government, 0.4 percent was held by the state of Nevada, and 0.4 percent was owned by local governments (Nevada Department of Conservation and Natural Resources, 2002). Figure 3 shows federal land management areas in the vicinity of the NTS. The white areas include state and local government holdings and private land.

The NTS is located within Nye County, which based on the 2000 Census, has an average population density of 1.8 persons per square mile, and is mostly rural. The census tracts within the immediate vicinity of the NTS have population densities of less than one person per square mile (U.S. Census Bureau, 2002a). However, the southern part of Nye County is developing rapidly. The entire population of Nye County was approximately 38,181 in July 2004, with most of the population spread out in the unincorporated Pahrump Valley area. The Nevada State Demographer's Office estimates that the population of the Pahrump area increased about 5.6 percent between July 2003 and July 2004 (Nevada State Demographer's Office, 2005). The Highway 160/Route 372 intersection in central Pahrump is about $92 \mathrm{~km}$ (57 mi) from the Area 3 RWMS (see Figure 1).

The nearest residential community to the Area 3 RWMS is about $57 \mathrm{~km}$ ( $35 \mathrm{mi})$ southwest in Amargosa Valley. This area is also growing, although not as fast as Pahrump. The July 1, 2004, population of Amargosa was estimated to be 1,211, a 3.6 percent increase over July 2003 (Nevada State Demographer's Office, 2005). Other nearby rural population centers include Beatty, which has had population declines over the past several years, and Indian Springs in Clark County. Indian Springs primarily supports Creech Air Force Base. Figure 3 shows locations and Table 1 summarizes 2004 population estimates.

The nearest major cities are in adjacent Clark County. Two of the United States' fastest growing cities are in the Las Vegas Metropolitan Area, which is about $105 \mathrm{~km}$ (65 mi) southeast of the NTS and $120 \mathrm{~km}(75 \mathrm{mi})$ southeast of the Area $3 \mathrm{RWMS}$. The North Las Vegas population grew 25 percent and the Henderson population grew 23 percent in the 39-month period between April 1, 2000, and July 1, 2003 (U.S. Census Bureau, 2004). The total population of Clark County was estimated to be 1,715,337 in July 2004. Although the Las Vegas area and Pahrump are growing rapidly, future population growth outward is expected to be limited by the availability of private land and water supplies. Land use in the immediate vicinity of the NTS is likely to remain rural. 


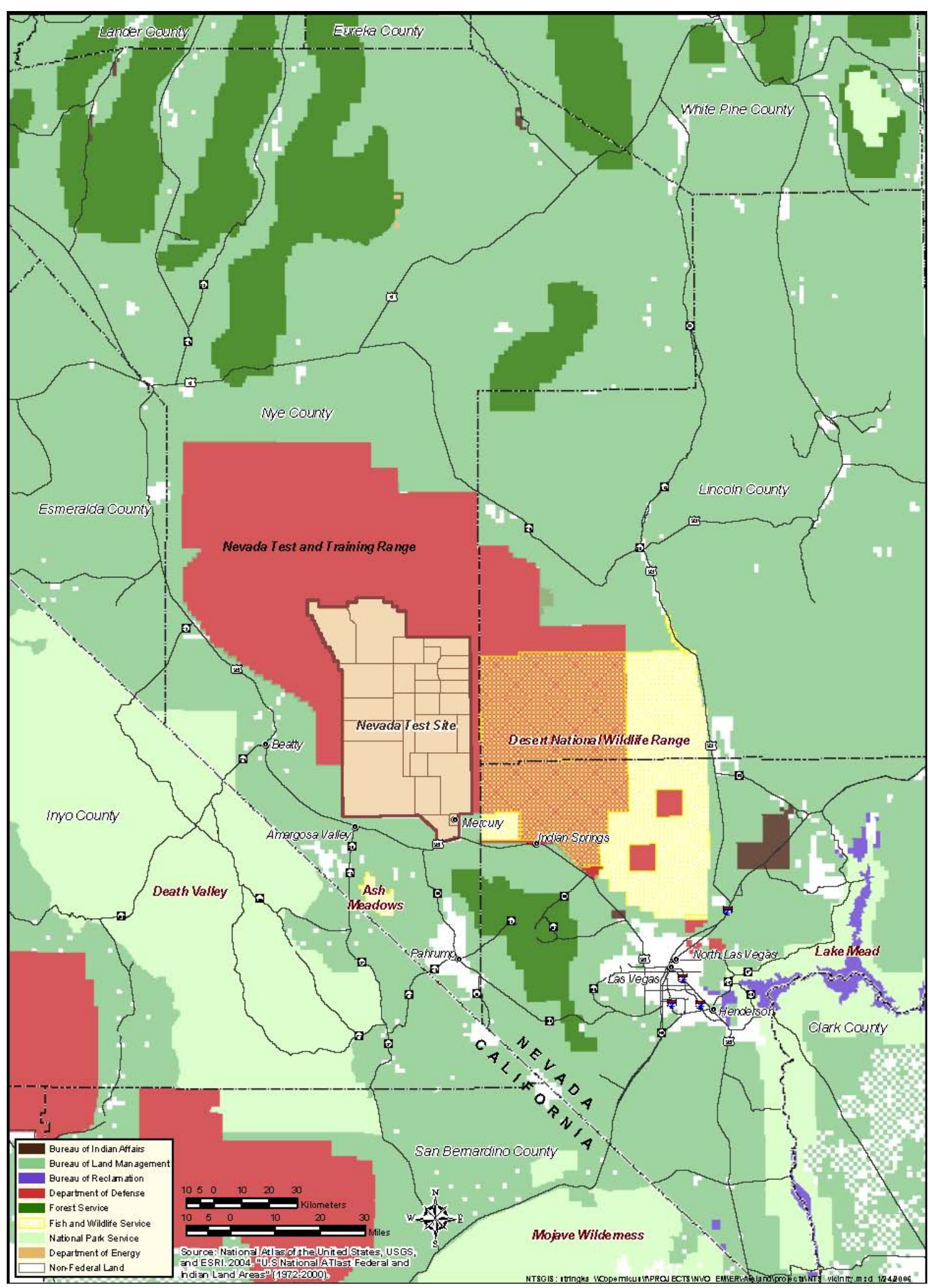

Figure 3

Federal Land Management Areas 
Table1

Population Centers

\begin{tabular}{|l|c|}
\hline \multicolumn{1}{|c|}{ City or Town } & $\begin{array}{c}\text { Population Estimate } \\
\text { July 1, 2004 }\end{array}$ \\
\hline Las Vegas & 549,571 \\
\hline North Las Vegas & 164,971 \\
\hline Henderson & 229,984 \\
\hline Summerlin & 17,841 \\
\hline Amargosa Valley & 1,211 \\
\hline Indian Springs & 1,661 \\
\hline Beatty & 981 \\
\hline $\begin{array}{l}\text { Pahrump Valley } \\
\text { (unincorporated) }\end{array}$ & 30,465 \\
\hline
\end{tabular}

${ }^{\mathrm{a}}$ Nevada State Demographer, 2005.

\subsection{Site Description}

The Area 3 RWMS site encompasses 48 hectares (120 acres) and seven collapse sinks south of the 3-03 Road. The collapse sinks are often referred to as "craters" in NTS literature, although not directly formed by an impact or ejection. The subsidence craters formed at the ground surface far above collapsed subsurface nuclear test cavities, after underground tests performed in the early 1960s. Characterization studies in the 1990s indicate that the characteristics of the disturbed alluvium in the collapse chimneys are very similar to the undisturbed alluvium away from the craters (see Section 12.0, Unsaturated Zone). Figure 4 shows the general site layout. At the time of formation, the seven craters within the Area 3 RWMS ranged from 121.9 to $178.8 \mathrm{~m}$ (400 to $580 \mathrm{ft}$ ) in diameter and from 14.0 to $32.0 \mathrm{~m}$ (46 to $105 \mathrm{ft}$ ) in depth (Planerer, 1996).

Five of the subsidence craters have been used for waste disposal: U-3ax, U-3bl, U-3ah, U-3at, and U-3bh. Two are undeveloped: U-3az and U-3bg. An eighth test site (U-3bm) at the south edge of the facility did not form a significant subsidence crater. Waste disposal records indicate that waste disposal in the craters began in 1968. DOE's contractor excavated the area between craters U-3ax and U-3bl to create the combined U-3ax/bl waste disposal cell. Similarly, the area between U-3ah and U-3at was excavated to create the U-3ah/at waste disposal cell. NNSA/NSO closed waste disposal cell U-3ax/bl with a final closure cover in 2000 under Resource Conservation and Recovery Act (RCRA) Interim Status. The "active" or "open" facility currently consists of the U-3ah/at and the U-3bh disposal cells and support infrastructure.

The facility is fenced with a controlled access gate on the north side and a rope gate at the west side. The Area 3 RWMS is protected from storm water run-on by earthen berms around the edges. Environmental monitoring infrastructure includes air particulate stations, a meteorological station, and thermoluminescent dosimeters. Time-domain reflectometry (TDR) sensors 


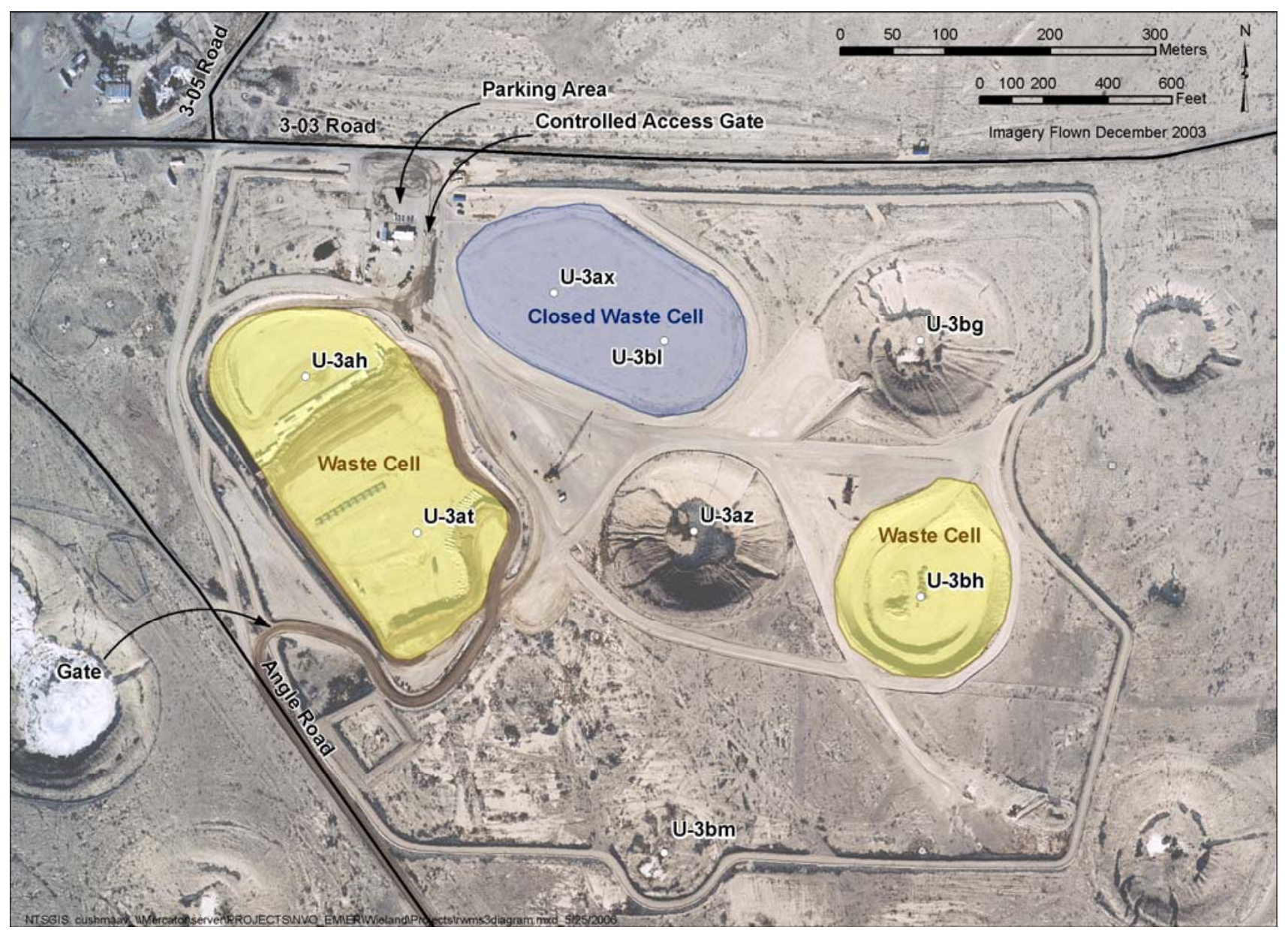

Figure 4

Area 3 Radioactive Waste Management Site

installed within the U-3ax/bl final cover and drainage lysimeters installed adjacent to the landfill cells provide near-surface infiltration data.

Waste disposal cells U-3ah/at and U-3bh were recently operationally closed with a cover of native soil. The operational covers have been placed with an average thickness of approximately $2.0 \mathrm{~m}(6.5 \mathrm{ft})$ and a minimum thickness of $1.2 \mathrm{~m}(4.0 \mathrm{ft})$. Each cell has about 14,148 cubic meters $\left(\mathrm{m}^{3}\right)\left(500,000\right.$ cubic feet $\left.\left[\mathrm{ft}^{3}\right]\right)$ of available space (personal communication, Clark to Wieland, 2006). The last expected delivery to the Area 3 RWMS for fiscal year (FY) 2006 was received and covered in April. DOE ordered that the Area 3 RWMS be placed in inactive status effective July 1, 2006.

The anticipated closure date for the U-3ah/at and U-3bh cells has changed over time due to changes in waste streams, availability of other LLW disposal sites, and other factors. BN (2005i) evaluated LLW capacity needs for a five-year strategic plan and concluded that there is adequate 
capacity at the Area 5 RWMS to handle the forecasted waste volume for the FY 2006 through FY 2010 period, and that significant capacity remained at the Area 3 RWMS to handle unexpected surges in the disposal volume. Final closure of the Area 3 RWMS U-3ah/at and U-3bh waste disposal cells is projected in FY 2008. 


\subsection{WASTE DISPOSAL OPERATIONS}

This section briefly describes waste disposal operations at the Area 3 RWMS including: waste disposal history; waste acceptance criteria; the containment, placement, covering, and tracking of waste; the volume and nature of the current inventory; and the latest published projection of the anticipated inventory at closure for waste disposal cells U-3ah/at and U-3bh. For more details, see the Integrated Closure and Monitoring Plan (ICMP) (BN, 2005c) and the Performance Assessment/Composite Analysis (PA/CA) (Shott et al., 2000). A report on the history of radioactive waste disposal in Areas 3 and 5 of the NTS is in preparation.

NNSA/NSO policies regarding the storage and disposal of radioactive waste are designed to achieve these goals:

- Ensure safe and compliant storage and disposal of radioactive waste, and be consistent with the current versions of all applicable federal, state, and local regulations.

- Protect the environment, personnel, and public from chemical and radiological hazards according to Title 40 Code of Federal Regulations (CFR); RCRA; Title 10 CFR 835, "Occupational Radiation Protection" (2001a); DOE Order 435.1, "Radioactive Waste Management" (2001c); and state of Nevada and applicable U. S. Department of Transportation regulations.

- Ensure that present and future radiation exposures are kept as low as reasonably achievable (ALARA) and do not exceed the radiation protection standards established in Title 10 CFR 835 (2001a).

- Maintain the Quality Assurance programs established and implemented to fulfill the requirements of DOE Order 435.1; Title 10 CFR 830.122, "Quality Assurance" (2001b); and DOE Order 414.1A, "Quality Assurance" (DOE, 2001b)

The implementation of waste acceptance, packaging, and other operational requirements has helped DOE achieve these goals at the Area 3 RWMS.

\subsection{History}

Historic waste disposal records indicate that the Area 3 RWMS began operations in July 1968. Five of the subsidence craters have been used for waste disposal. All of the material disposed to date at the Area 3 RWMS is unclassified. Various documents prepared by BN and DOE describe the history of Area 3 RWMS waste operations in detail: the ICMP (BN, 2005c); the PA/CA (Shott et al., 2000); the Characterization Reports for Corrective Action Unit [CAU] 110: Area 3 U-3ax/bl (BN, 1999b); and a written communication (BN Program Integration Data Management Support, 2004).

The U-3ax/bl disposal cell operated from 1968 to 1987 . About 80 percent of the waste volume in $\mathrm{U}-3 \mathrm{ax} / \mathrm{bl}$ is radiologically contaminated bulk soil and metal debris from the cleanup of atmospheric weapon test sites on the NTS. Low-level mixed waste (LLMW) also was disposed at this cell. 
The bottom of the U-3ax crater was filled first. In 1984, when the waste level reached the bottom of the adjacent U-3bl crater, the soil between these craters was removed to create one contiguous pit and waste disposal extended into the U-3bl side. In 1985, Sealand containers were placed in the excavated area between the two craters and, in 1987, various sized containers were disposed in the upper part of U-3bl. An operational cover of soil about $1.5 \mathrm{~m}(5 \mathrm{ft})$ thick was placed over the waste after disposal operations stopped. See BN (1999b) and Shott et al. (2000) for further details.

The U-3ax/bl cell was closed as a hazardous waste landfill under RCRA Interim Status, in accordance with the reissued RCRA Part B operational permit NEV HW009 (Nevada Division of Environmental Protection [NDEP], 2000) and the Federal Facility Agreement and Consent Order (FFACO) (NDEP et al., 1996). A vegetated monolayer-evapotranspirative (ET) closure cover was constructed on $\mathrm{U}-3 \mathrm{ax} / \mathrm{bl}$ in 2000 . The cover is a single layer of soil, representative of the surrounding native alluvium, measuring approximately $3 \mathrm{~m} \mathrm{(10} \mathrm{ft)} \mathrm{thick.} \mathrm{Because} \mathrm{disposal}$ ceased before September 1988, this cell is exempt from the requirements of DOE Order 435.1 (2001c), which superseded DOE Order 5820.2A (1988), including consideration in the PA calculations. However, the LLW in this disposal cell is covered by the CA for the Area 3 RWMS. Details of the closure were presented in NNSA/NSO (2001).

Disposal at the U-3ah/at cell began in 1987. After the U-3at crater received two tiers of uncontained soil and debris from the cleanup of atmospheric weapons test sites, soil between the U-3ah and U-3at craters was excavated to create one contiguous pit. The bulk of the waste in U-3ah/at is LLW generated by off-site DOE generators. From 1989 to 2000, four tiers of waste in cargo containers were disposed in U-3ah/at. Since 1997, soft-sided containers of plutoniumcontaminated soil from the cleanup of safety shots at the Tonopah Test Range were disposed (BN, 2005c). U-3ah/at is subject to the requirements of DOE Order 435.1 (2001c).

Disposal operation at U-3bh began in May 1997. DOE anticipated using U-3bh primarily to dispose plutonium-contaminated soil from the CLEAN SLATE 1, 2, and 3 sites. It has received unpackaged bulk LLW, plutonium-contaminated soil, and other waste in soft-sided packages. The waste is covered with uncontaminated soil (Shott et al., 2000). Waste operations at U-3bh are subject to the requirements of DOE Order 435.1 (2001c).

\subsection{Waste Types and Acceptance Criteria}

The Area 3 RWMS accepts contained and uncontained bulk LLW from NTS and off-site DOE generators. The material is unclassified.

For its radioactive waste disposal sites at the NTS, NNSA/NSO has established the Nevada Test Site Waste Acceptance Criteria (NTSWAC) (NNSA/NSO, 2005b). The NTSWAC provides the terms and conditions under which the NTS will accept waste for disposal. It includes requirements for the characterization, waste form, packaging, transfer of material, and the generator waste certification program. Radioactive Waste Acceptance Program personnel review each waste generator's program and documentation for compliance to the NTSWAC. Upon arrival at the NTS, waste shipments are inspected to verify placards, manifests, marking and labeling, and container integrity (if not bulk waste) (Becker et al., 2002).

There are detailed waste criteria requirements for acceptance at the NTS of transuranics (TRU), radionuclides, polychlorinated biphenyls, explosives, pyrophorics, asbestiform LLW, sealed 
sources, radioactive animal carcasses, low-level beryllium waste, and classified materials/waste. There are also requirements for minimization of free liquids, immobilization of particulates and gases, chemical and structural stability, chemical compatibility, and the use of chelating agents. The Area 3 RWMS accepts only LLW.

Commercial Greater-Than-Class C wastes (as defined by Title 10 CFR 61.55 [2001c]) generated by the U.S. Nuclear Regulatory Commission licensees and etiological agents are not accepted at the NTS.

Treatment, stabilization, and packaging requirements address specific hazards. Facility waste packaging acceptance criteria fulfill all applicable DOE orders and federal requirements. Package requirements address design, nuclear safety, radiation levels and activity limits, nuclear heating, strength, shielding, and sealing. For further information on waste acceptance criteria, see the NTSWAC (NNSA/NSO, 2005b).

\subsection{Waste Containers}

Early waste deposits were not contained; the waste included large bulky demolition debris. Most of the waste delivered to the Area 3 RWMS is now delivered in metal cargo containers such as Sealand boxes or soft-sided containers. The containers are off-loaded from the delivery trucks and disposed, as is, without opening them. For further information, see the ICMP (BN, 2005c).

\subsection{Waste Placement and Operational Covers}

Waste is transported to the Area 3 RWMS on trucks. On arrival, NSTec checks manifests and inspects trucks visually and with instrumentation to ensure that there is no leakage of contaminated material from the containers. The contractor offloads the cleared containers and emplaces the waste in the landfill cell. Unloaded trucks are released from the NTS only after they have been surveyed for contamination and found to be below release limits.

The bulk waste was placed in tiers approximately $3 \mathrm{~m}(10 \mathrm{ft})$ thick separated by about $0.9-\mathrm{m}$ (3-ft)-thick layers of clean backfill. Waste containers were arranged in layers and covered by an

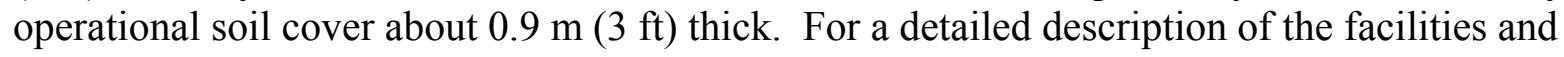
waste placement operations, refer to the PA/CA (Shott et al., 2000).

In 2006, thicker operational covers were placed on the active waste disposal cells U-3ah/at and U-3bh. According to the facility manager, the average thickness of the operational covers is about $2.0 \mathrm{~m}(6.5 \mathrm{ft})$ and a minimum thickness of $1.2 \mathrm{~m}(4.0 \mathrm{ft})$ (personal communication, Clark to Wieland, 2006). The operational covers are comprised of uncontaminated native alluvium from a borrow pit located south of the site in Area 3.

\subsection{Waste Tracking}

The Low-Level Waste Inventory System User's Guide (BN, 2005b) provides detailed information on the structure and history of LLW and LLMW tracking systems at the NTS, including field codes and limitations. The completeness, quality, and level of detail of inventory records have changed over time. A brief summary of the evolution of inventory tracking follows. This section was modified from a summary prepared for the Characterization Report for the 92-Acre Area of the Area 5 Radioactive Waste Management Site, Nevada Test Site, Nevada (BN, 2006c). 
The oldest NTS waste disposal records generally show load origin, a brief description of the material and containers, estimated radioactivity, date of disposal, and the disposal location (Area 3 or Area 5 RWMS). If not specified in the paper records, the specific disposal crater can be inferred from the burial date and history of the development of the disposal features.

Many years ago, the original paper records for the oldest Area 5 RWMS cells and Area 3 RWMS $\mathrm{U}-3 \mathrm{ax} / \mathrm{bl}$ cell were scanned into a digital format and archived. The quality of some of these scanned images is poor and some of the data are difficult to read. There is also uncertainty as to the completeness of the scanned waste records (personal communication, Dolenc to Wieland, 2005). There are no historic paper records for the U-3bh and U-3ah/at active disposal cells of the Area 3 RWMS because these disposal cells were developed later, when computerized database tracking was in place.

The Radioactive Waste Management System was developed in 1988 to meet requirements of DOE Order 5820.2A (1988) (subsequently replaced by DOE Order 435.1 [2001c]). The Radioactive Waste Management System tabulated basic information on a per-shipment level for waste received from August 13, 1974, through 1992. A container tracking system was also developed to store older data through FY 1992. The Radioactive Waste Management System had design flaws, typical of early databases and early programming capabilities, which permitted inconsistent entries, incomplete records, and the creation of orphan records due to poor interrelationships between the master tables and detail tables. Users of the system could modify, delete, and add data in sub-tables without changing, deleting, or adding records to the master table.

The draft FY 2005 review of historical data by Program Integration Data Management Support staff attempted to relate orphan nuclide and container data back to generator shipments. The Radioactive Waste Management System includes records for the closed U-3ax/bl waste disposal cell and the active U-3ah/at waste disposal cell. This database does not include records for the U-3bh waste disposal cell, because U-3bh was not developed until 1997.

After September 30, 1992, the Low-Level Waste Information System (LWIS) Oracle ${ }^{(}$ application was implemented. Data in this database are stored in a single record, indexed by package. The level of characterization detail and burial location detail also improved. Burial location is provided based on an alphanumeric grid. The tier and location within the cell were recorded. The Oracle relational database structure of the LWIS prevents some of the quality and orphan data problems that plagued the Radioactive Waste Management System. The Web applications used by generators and waste operations personnel to input data also have built-in validation features that help reduce errors in the database. Bar-coding and scanning systems were implemented to facilitate package tracking.

In May 1997, the NTSWAC system, an enhancement to LWIS, was implemented. The principal improvements are that it accepts multiple waste profiles and includes more detailed information on waste form and treatment. This is the waste tracking system currently in use. The Waste Management Infobank System combines data from source databases, intranet, and internet sites needed to support the Waste Management Program.

To document and improve the accuracy of the historic waste inventory for 1961 through 1978 and make the scattered information more useable, BN reviewed and cross-checked several historic tracking systems, including paper records and previously scanned records. BN then 
incorporated the waste disposal data into a searchable spreadsheet. Chemical hazards were not profiled routinely before landfill regulations and RCRA were implemented. The presence of known hazardous constituents and suspected hazardous constituents, and consequently the classification of some waste disposed at the NTS RWMSs as potential LLMW, was inferred from general waste descriptions, historic photographs, and other sources. The early Radioactive Waste Management System database covering waste disposal from the mid-1970s through 1992 was also checked and cross-checked with other documentation to attempt to verify the locations, volumes, and characteristics of the wastes disposed. A report documenting the review of these records is under development.

Waste accounting practices have changed significantly since the $1960 \mathrm{~s}$. The waste volume estimates are most accurate for the newest waste disposal cells at the NTS, such as waste disposal cell U-3bh. Inventory estimates for the active Area 3 RWMS waste cells are presented in the following sections.

\subsection{Current Inventory}

Waste inventory nuclide activity was summarized in the PA/CA by Shott et al. (2000). The Area 3 RWMS PA evaluated inventory at U-3ah/at and U-3bh. PA requirements under DOE Order 435.1 apply to LLW disposed after September 26, 1988. The CA evaluates potential dose from all potential sources, not just the active facility. The CA also estimated inventory at the closed U-3ax/bl cell, which received waste before 1988. Detailed inventory information relevant to closure of the U-3ax/bl disposal cell was presented in the characterization report for that cell (BN, 1999b).

A small fraction of the U-3ah/at inventory was deposited before 1988. Table 2 summarizes the disposal periods, total volumes, and total activity for U-3ah/at and U-3bh through July 2006 (personal communication, Denton to Wieland, 2006). The records for the U-3ah/at waste disposal cell are extracted from the historical Radioactive Waste Management System database and from the current database, which covers the period from September 1992 to present. The records for U-3bh, which was developed in 1997, are all in the current database.

The most recent published inventory update was presented in the Fiscal Year 2005 Annual Summary Report for the Area 3 and Area 5 Radioactive Waste Management Sites at the Nevada Test Site, Nye County, Nevada (BN, 2006a). The report notes that there was a spike in disposal rates between FY 2001 and FY 2004. FY 2005 and projected future disposal rates are expected to be more like earlier operations (BN, 2006a). The volume of the current inventory is greater than was projected in the initial PA and CA evaluations. Recent new inventory at U-3ah/at includes Melton Valley Tanks waste from Oak Ridge Operations and remaining thorium waste from the Fernald Environmental Management Project. Thorium waste was sent to the Area 3 RWMS after the lower level of P06U at the Area 5 RWMS was filled to capacity. The last shipment of LLW disposed at the Area 3 RWMS facility, as of the time of preparation of this report, was on April 19, 2006 (personal communication, Denton to Wieland, 2006). NNSA/NSO instructed BN to place the facility on inactive status effective July 1, 2006 (NNSA/NSO, 2005a). 
Table 2

Waste Disposal Records through July 2006

\begin{tabular}{|l|c|c|c|c|c|c|c|}
\hline Location & $\begin{array}{c}\text { Shipment } \\
\text { Count }\end{array}$ & $\begin{array}{c}\text { Package } \\
\text { Count }\end{array}$ & First Date & $\begin{array}{c}\text { Last } \\
\text { Date }\end{array}$ & $\begin{array}{c}\text { Volume } \\
\left(\mathbf{m}^{3}\right)\end{array}$ & Volume $\left(\mathbf{f t}^{3}\right)$ & $\begin{array}{c}\text { Total } \\
\text { Curies }\end{array}$ \\
\hline U-3ah/at & 5,993 & 27,166 & $11 / 12 / 1987$ & $4 / 19 / 2006$ & $271,482.77$ & $9,587,142.52$ & $543,001.376$ \\
\hline U-3bh & 1,616 & 2,737 & $5 / 20 / 1997$ & $12 / 6 / 2005$ & $43,962.89$ & $1,552,505.44$ & $342,432.842$ \\
\hline
\end{tabular}

Source:

Personal communications, R. Denton. Data extracted July 26, 2006, from databases maintained by National Security Technologies, LLC, for the Department of Energy. The databases are commonly known as the Historical and the Current databases.

\subsection{Projected Inventory at Closure}

The projections of inventory at closure have evolved since the original estimates in the PA/CA, due to the approval of new generators, changes in waste streams, and changes in rates of disposal.

Revised closure estimates projected from waste disposal records through FY 2005 are presented in Tables 3, 4, and 5. These closure inventory estimates are presented by waste disposal cell and by nuclide. The estimates are derived using the Area 3 Inventory GoldSim ${ }^{\circledR}$ probabilistic model. Multiple Monte Carlo simulations produce estimates of the inventory distribution; concentration values in the tables are the mean values of many model realizations. The standard deviation (SD) indicates the scatter around the mean for each nuclide data set from the multiple model realizations. These closure concentration projections assume that future mean concentrations of individual nuclides will be similar to the mean concentrations of waste disposed in the past. The future volumes are estimates from waste generators.

The last entry in the last column in the closure inventory table, geometric mean of the sum of fractions, is the sum over all radionuclides of the ratio of the closure inventory waste concentration to the waste concentration action limit from the NTSWAC (NNSA/NSO, 2005b). The action limit represents the maximum concentration that may be disposed. The total sum of fractions for $\mathrm{U}-3 \mathrm{ax} / \mathrm{bl}$ was $6.9 \mathrm{E}-02$; for $\mathrm{U}-3 \mathrm{ah} / \mathrm{at}$ was $2.0 \mathrm{E}-02$; and for $\mathrm{U}-3 \mathrm{bh}$ was $2.4 \mathrm{E}-02$. This means that the expected inventory activity at closure at U-3ax/bl would be about 6.9 percent of the maximum amount permitted under the performance objectives, 2.0 percent for U-3ah/at, and 2.4 percent for $\mathrm{U}-3 \mathrm{bh}(\mathrm{BN}, 2006 \mathrm{a})$. These percentages indicate that the projected inventory meets the inventory criteria. A sum of fractions greater than 1 (i.e., more than 100 percent of the maximum allowed based on the action limits) would mean that the inventory performance objectives had not been met. 
Table 3

Closure Inventory Estimate for the U-3ax/bl Disposal Cell

\begin{tabular}{|c|c|c|c|c|}
\hline Nuclide & $\begin{array}{l}\text { Geometric } \\
\text { Mean } \\
\text { (Ci) }\end{array}$ & $\begin{array}{c}\text { Geometric } \\
\text { Mean }\left(\mathrm{Ci} / \mathrm{m}^{3}\right)\end{array}$ & $\begin{array}{c}\text { Geometric } \\
\text { Standard } \\
\text { Deviation } \\
\text { (Ci) }\end{array}$ & $\begin{array}{c}\text { Geometric } \\
\text { Mean of the } \\
\text { Sum of } \\
\text { Fractions }\end{array}$ \\
\hline${ }^{3} \mathrm{H}$ & $6.1 \mathrm{E}+03$ & 2.7E-02 & 2.95 & 1.8E-07 \\
\hline${ }^{14} \mathrm{C}$ & $2.4 \mathrm{E}+00$ & 1.1E-05 & 3.10 & 1.7E-03 \\
\hline${ }^{26} \mathrm{Al}$ & $9.1 \mathrm{E}-05$ & $4.0 \mathrm{E}-10$ & 3.16 & $\mathrm{NL}$ \\
\hline${ }^{36} \mathrm{Cl}$ & 5.3E-01 & $2.3 \mathrm{E}-06$ & 3.15 & $7.8 \mathrm{E}-06$ \\
\hline${ }^{39} \mathrm{Ar}$ & $2.6 \mathrm{E}+00$ & 1.1E-05 & 3.17 & $\mathrm{NL}$ \\
\hline${ }^{40} \mathrm{~K}$ & 1.4E-01 & $6.2 \mathrm{E}-07$ & 3.05 & $\mathrm{NL}$ \\
\hline${ }^{41} \mathrm{Ca}$ & $3.8 \mathrm{E}+00$ & 1.7E-05 & 3.13 & $\mathrm{NL}$ \\
\hline${ }^{60} \mathrm{Co}$ & $1.9 \mathrm{E}+00$ & $8.2 \mathrm{E}-06$ & 2.41 & $\mathrm{NL}$ \\
\hline${ }^{59} \mathrm{Ni}$ & $9.8 \mathrm{E}-02$ & 4.3E-07 & 3.12 & 2.0E-09 \\
\hline${ }^{63} \mathrm{Ni}$ & $8.7 \mathrm{E}+00$ & $3.8 \mathrm{E}-05$ & 3.17 & 5.7E-08 \\
\hline${ }^{85} \mathrm{Kr}$ & $3.3 E+00$ & $1.5 \mathrm{E}-05$ & 3.06 & $\mathrm{NL}$ \\
\hline${ }^{90} \mathrm{Sr}$ & $1.6 \mathrm{E}+02$ & 7.2E-04 & 3.06 & 1.8E-05 \\
\hline${ }^{93} \mathrm{Zr}$ & 1.3E-02 & 5.9E-08 & 3.04 & $1.5 \mathrm{E}-10$ \\
\hline${ }^{93 \mathrm{~m}} \mathrm{Nb}$ & $3.1 E+00$ & 1.3E-05 & 3.25 & $\mathrm{NL}$ \\
\hline${ }^{94} \mathrm{Nb}$ & $3.2 \mathrm{E}+00$ & 1.4E-05 & 3.15 & $\mathrm{NL}$ \\
\hline${ }^{99} \mathrm{Tc}$ & 3.3E-01 & 1.5E-06 & 2.19 & 4.9E-07 \\
\hline${ }^{107} \mathrm{Pd}$ & $6.0 \mathrm{E}-04$ & 2.6E-09 & 3.07 & 7.4E-13 \\
\hline${ }^{113 m} \mathrm{Cd}$ & $2.7 E+00$ & $1.2 \mathrm{E}-05$ & 3.18 & $\mathrm{NL}$ \\
\hline${ }^{121 \mathrm{~m}} \mathrm{Sn}$ & $3.7 \mathrm{E}+01$ & 1.6E-04 & 3.10 & NL \\
\hline${ }^{126} \mathrm{Sn}$ & $5.8 \mathrm{E}-03$ & $2.5 \mathrm{E}-08$ & 3.05 & 1.6E-06 \\
\hline${ }^{129} I$ & $3.1 \mathrm{E}-04$ & 1.3E-09 & 3.06 & 1.7E-08 \\
\hline${ }^{135} \mathrm{Cs}$ & 1.0E-02 & 4.6E-08 & 3.05 & $6.1 \mathrm{E}-10$ \\
\hline${ }^{137} \mathrm{Cs}$ & $2.2 \mathrm{E}+02$ & 9.9E-04 & 3.02 & 1.1E-04 \\
\hline${ }^{151} \mathrm{Sm}$ & $1.4 \mathrm{E}+01$ & 6.3E-05 & 3.06 & 1.9E-09 \\
\hline${ }^{150} \mathrm{Eu}$ & $5.8 E+00$ & $2.5 \mathrm{E}-05$ & 3.37 & 1.0E-20 \\
\hline${ }^{152} \mathrm{Eu}$ & $2.2 \mathrm{E}+01$ & 9.8E-05 & 3.25 & 7.6E-08 \\
\hline${ }^{154} \mathrm{Eu}$ & $5.6 \mathrm{E}+00$ & 2.5E-05 & 3.19 & 7.6E-11 \\
\hline${ }^{152} \mathrm{Gd}$ & 3.75E-12 & 1.6E-17 & 3.22 & $\mathrm{NL}$ \\
\hline${ }^{166 \mathrm{~m}} \mathrm{Ho}$ & $1.2 \mathrm{E}-01$ & 5.4E-07 & 3.18 & $\mathrm{NL}$ \\
\hline${ }^{210} \mathrm{~Pb}$ & $8.8 E+00$ & 3.9E-05 & 3.74 & 1.1E-07 \\
\hline${ }^{226} \mathrm{Ra}$ & $1.5 E+01$ & $6.5 \mathrm{E}-05$ & 3.74 & 6.7E-02 \\
\hline${ }^{228} \mathrm{Ra}$ & $3.6 \mathrm{E}-02$ & 1.6E-07 & 2.54 & $\mathrm{NL}$ \\
\hline
\end{tabular}


Table 3

Closure Inventory Estimate for the U-3ax/bl Disposal Cell

(continued)

\begin{tabular}{|c|c|c|c|c|}
\hline Nuclide & $\begin{array}{l}\text { Geometric } \\
\text { Mean } \\
\text { (Ci) }\end{array}$ & $\begin{array}{c}\text { Geometric } \\
\text { Mean }\left(\mathrm{Ci} / \mathrm{m}^{3}\right)\end{array}$ & $\begin{array}{c}\text { Geometric } \\
\text { Standard } \\
\text { Deviation } \\
\text { (Ci) }\end{array}$ & $\begin{array}{l}\text { Geometric } \\
\text { Mean of the } \\
\text { Sum of } \\
\text { Fractions }\end{array}$ \\
\hline${ }^{227} \mathrm{Ac}$ & 1.7E-05 & $7.4 \mathrm{E}-11$ & 2.08 & $2.7 E-12$ \\
\hline${ }^{228} \mathrm{Th}$ & $2.2 \mathrm{E}-01$ & $9.5 \mathrm{E}-07$ & 2.78 & NL \\
\hline${ }^{229} \mathrm{Th}$ & 2.7E-04 & 1.2E-09 & 3.02 & 1.1E-08 \\
\hline${ }^{230} \mathrm{Th}$ & $6.4 \mathrm{E}-04$ & 2.8E-09 & 1.86 & 1.1E-06 \\
\hline${ }^{232} \mathrm{Th}$ & 3.7E-02 & 1.6E-07 & 2.54 & 7.4E-06 \\
\hline${ }^{231} \mathrm{~Pa}$ & 5.2E-05 & $2.3 E-10$ & 2.11 & 6.0E-09 \\
\hline${ }^{232} \mathrm{U}$ & 1.6E-01 & 6.9E-07 & 3.15 & 2.8E-06 \\
\hline${ }^{233} \mathrm{U}$ & 8.1E-02 & 3.6E-07 & 3.04 & 4.3E-07 \\
\hline${ }^{234} \mathrm{U}$ & $2.4 \mathrm{E}+00$ & 1.0E-05 & 1.99 & 2.0E-05 \\
\hline${ }^{235} \mathrm{U}$ & $9.2 \mathrm{E}-02$ & 4.1E-07 & 2.14 & 1.3E-06 \\
\hline${ }^{236} \mathrm{U}$ & $6.4 \mathrm{E}-02$ & 2.8E-07 & 2.85 & 8.7E-08 \\
\hline${ }^{238} \mathrm{U}$ & $1.2 E+00$ & 5.1E-06 & 2.06 & $3.2 \mathrm{E}-06$ \\
\hline${ }^{237} \mathrm{~Np}$ & 1.3E-02 & 5.8E-08 & 2.35 & $3.0 \mathrm{E}-06$ \\
\hline${ }^{238} \mathrm{Pu}$ & $5.2 E+00$ & 2.3E-05 & 3.05 & 7.1E-06 \\
\hline${ }^{239} \mathrm{Pu}$ & $2.8 \mathrm{E}+01$ & $1.2 \mathrm{E}-04$ & 3.00 & 2.0E-04 \\
\hline${ }^{240} \mathrm{Pu}$ & $7.4 \mathrm{E}+00$ & 3.3E-05 & 3.02 & 5.2E-05 \\
\hline${ }^{241} \mathrm{Pu}$ & $2.0 \mathrm{E}+01$ & 8.6E-05 & 3.05 & $6.2 E-06$ \\
\hline${ }^{242} \mathrm{Pu}$ & 2.8E-03 & $1.2 \mathrm{E}-08$ & 3.03 & 1.9E-08 \\
\hline${ }^{241} \mathrm{Am}$ & $9.0 \mathrm{E}+00$ & 4.0E-05 & 3.00 & 8.1E-05 \\
\hline${ }^{243} \mathrm{Am}$ & 1.2E-03 & 5.4E-09 & 3.01 & 2.8E-08 \\
\hline${ }^{244} \mathrm{Cm}$ & $3.5 E-01$ & $1.5 \mathrm{E}-06$ & 3.07 & 7.0E-09 \\
\hline Total & $6.7 E+03$ & $3.0 \mathrm{E}-02$ & & $6.9 \mathrm{E}-02$ \\
\hline
\end{tabular}

Notes:

NL No waste concentration limit.

The U-3ax/bl waste disposal cell was closed in 2000 .

Source:

Bechtel Nevada, 2006a. Fiscal Year 2005 Annual Summary Report for the Area 3 and Area 5

Radioactive Waste Management Sites at the Nevada Test Site, Nye County, Nevada. Las

Vegas, Nevada. January 24, 2006. Unbound letter report. 10 pages. 
Table 4

Closure Inventory Estimate for the U-3ah/at Disposal Cell Projected from Inventory Data through FY 2005

\begin{tabular}{|c|c|c|c|c|}
\hline Nuclide & $\begin{array}{l}\text { Geometric } \\
\text { Mean } \\
\text { (Ci) }\end{array}$ & $\begin{array}{c}\text { Geometric } \\
\text { Mean }\left(\mathrm{Ci} / \mathrm{m}^{3}\right)\end{array}$ & $\begin{array}{c}\text { Geometric } \\
\text { Standard } \\
\text { Deviation } \\
\text { (Ci) }\end{array}$ & $\begin{array}{l}\text { Geometric } \\
\text { Mean of the } \\
\text { Sum of } \\
\text { Fractions }\end{array}$ \\
\hline${ }^{3} \mathrm{H}$ & $4.0 \mathrm{E}+05$ & $1.2 \mathrm{E}+00$ & 1.91 & 7.7E-06 \\
\hline${ }^{14} \mathrm{C}$ & $2.9 E+00$ & 8.5E-06 & 1.64 & 1.4E-03 \\
\hline${ }^{26} \mathrm{Al}$ & 2.7E-06 & $7.8 \mathrm{E}-12$ & 2.41 & NL \\
\hline${ }^{36} \mathrm{Cl}$ & 1.7E-02 & 5.0E-08 & 2.22 & 1.7E-07 \\
\hline${ }^{39} \mathrm{Ar}$ & 7.4E-02 & 2.2E-07 & 2.28 & $\mathrm{NL}$ \\
\hline${ }^{42} \mathrm{Ar}$ & 1.7E-02 & 5.1E-08 & 1.82 & $\mathrm{NL}$ \\
\hline${ }^{40} \mathrm{~K}$ & 3.6E-02 & 1.1E-07 & 1.92 & $\mathrm{NL}$ \\
\hline${ }^{41} \mathrm{Ca}$ & $1.1 \mathrm{E}-01$ & $3.2 \mathrm{E}-07$ & 2.29 & NL \\
\hline${ }^{44} \mathrm{Ti}$ & 4.1E-01 & $1.2 \mathrm{E}-06$ & 1.85 & $\mathrm{NL}$ \\
\hline${ }^{60} \mathrm{Co}$ & 5.7E-01 & 1.7E-06 & 1.66 & NL \\
\hline${ }^{59} \mathrm{Ni}$ & 3.4E-03 & 9.9E-09 & 2.06 & $4.5 \mathrm{E}-11$ \\
\hline${ }^{63} \mathrm{Ni}$ & $6.4 \mathrm{E}+00$ & 1.9E-05 & 1.64 & $2.8 \mathrm{E}-08$ \\
\hline${ }^{79} \mathrm{Se}$ & 7.9E-04 & 2.3E-09 & 1.97 & $\mathrm{NL}$ \\
\hline${ }^{85} \mathrm{Kr}$ & $2.5 \mathrm{E}-01$ & 7.2E-07 & 1.96 & $\mathrm{NL}$ \\
\hline${ }^{90} \mathrm{Sr}$ & $1.1 \mathrm{E}+04$ & $3.4 \mathrm{E}-02$ & 2.52 & 8.3E-04 \\
\hline${ }^{93} \mathrm{Zr}$ & $3.9 \mathrm{E}-04$ & 1.1E-09 & 2.18 & 3.0E-12 \\
\hline${ }^{93 \mathrm{~m}} \mathrm{Nb}$ & 1.3E-01 & 3.9E-07 & 2.36 & $\mathrm{NL}$ \\
\hline${ }^{94} \mathrm{Nb}$ & 9.3E-02 & 2.7E-07 & 2.35 & $\mathrm{NL}$ \\
\hline${ }^{99} \mathrm{Tc}$ & $6.4 \mathrm{E}+01$ & 1.9E-04 & 1.73 & 6.3E-05 \\
\hline${ }^{107} \mathrm{Pd}$ & 1.7E-05 & 5.1E-11 & 2.19 & $1.4 \mathrm{E}-14$ \\
\hline${ }^{113 m} \mathrm{Cd}$ & 1.3E-01 & 4.0E-07 & 2.27 & $\mathrm{NL}$ \\
\hline${ }^{121 \mathrm{~m}} \mathrm{Sn}$ & $1.2 \mathrm{E}+00$ & 3.6E-06 & 2.39 & $\mathrm{NL}$ \\
\hline${ }^{126} \mathrm{Sn}$ & $1.8 \mathrm{E}-02$ & 5.3E-08 & 2.07 & 3.3E-06 \\
\hline${ }^{129} I$ & $1.4 \mathrm{E}-02$ & 4.1E-08 & 1.84 & 5.3E-07 \\
\hline${ }^{133} \mathrm{Ba}$ & 3.1E-01 & $9.1 \mathrm{E}-07$ & 1.80 & $\mathrm{NL}$ \\
\hline${ }^{135} \mathrm{Cs}$ & 3.0E-04 & $8.8 \mathrm{E}-10$ & 2.16 & $1.2 \mathrm{E}-11$ \\
\hline${ }^{137} \mathrm{Cs}$ & $6.9 E+03$ & $2.0 \mathrm{E}-02$ & 1.64 & $2.2 \mathrm{E}-03$ \\
\hline${ }^{151} \mathrm{Sm}$ & 4.5E-01 & 1.3E-06 & 2.18 & 4.1E-11 \\
\hline
\end{tabular}


Table 4

Closure Inventory Estimate for the U-3ah/at Disposal Cell Projected from Inventory Data through FY 2005

(continued)

\begin{tabular}{|c|c|c|c|c|}
\hline Nuclide & $\begin{array}{l}\text { Geometric } \\
\text { Mean } \\
\text { (Ci) }\end{array}$ & $\begin{array}{c}\text { Geometric } \\
\text { Mean }\left(\mathrm{Ci} / \mathrm{m}^{3}\right)\end{array}$ & $\begin{array}{c}\text { Geometric } \\
\text { Standard } \\
\text { Deviation } \\
\text { (Ci) }\end{array}$ & $\begin{array}{c}\text { Geometric } \\
\text { Mean of the } \\
\text { Sum of } \\
\text { Fractions }\end{array}$ \\
\hline${ }^{150} \mathrm{Eu}$ & 2.1E-01 & $6.0 \mathrm{E}-07$ & 2.64 & $\mathrm{NL}$ \\
\hline${ }^{152} \mathrm{Eu}$ & $2.1 \mathrm{E}+00$ & 6.1E-06 & 1.71 & 4.7E-09 \\
\hline${ }^{154} \mathrm{Eu}$ & 6.6E-01 & $1.9 \mathrm{E}-06$ & 1.86 & 5.9E-12 \\
\hline${ }^{152} \mathrm{Gd}$ & $1.1 \mathrm{E}-13$ & 3.36E-19 & 1.98 & $\mathrm{NL}$ \\
\hline${ }^{166 m} \mathrm{Ho}$ & 3.7E-03 & 1.1E-08 & 2.30 & $1.0 \mathrm{E}-20$ \\
\hline${ }^{207} \mathrm{Bi}$ & 1.6E-05 & 4.6E-11 & 2.18 & $1.5 \mathrm{E}-11$ \\
\hline${ }^{210} \mathrm{~Pb}$ & $2.7 \mathrm{E}+00$ & 7.9E-06 & 1.76 & 2.3E-08 \\
\hline${ }^{226} \mathrm{Ra}$ & $3.3 E+00$ & 9.6E-06 & 1.92 & $9.9 \mathrm{E}-03$ \\
\hline${ }^{228} \mathrm{Ra}$ & 3.3E-01 & 9.6E-07 & 1.51 & $\mathrm{NL}$ \\
\hline${ }^{227} \mathrm{Ac}$ & 1.1E-01 & $3.1 \mathrm{E}-07$ & 1.90 & $1.2 \mathrm{E}-08$ \\
\hline 228Th & $2.4 \mathrm{E}+00$ & 7.0E-06 & 1.83 & $\mathrm{NL}$ \\
\hline 229Th & 7.3E-04 & 2.1E-09 & 1.80 & $1.9 \mathrm{E}-08$ \\
\hline 230Th & $1.5 \mathrm{E}+00$ & 4.3E-06 & 1.74 & 1.7E-03 \\
\hline${ }^{232} \mathrm{Th}$ & 4.0E-01 & $1.2 \mathrm{E}-06$ & 1.54 & 5.3E-05 \\
\hline${ }^{231} \mathrm{~Pa}$ & $8.2 \mathrm{E}-03$ & $2.4 \mathrm{E}-08$ & 1.83 & $6.4 \mathrm{E}-07$ \\
\hline${ }^{232} \mathrm{U}$ & $2.0 \mathrm{E}+00$ & 5.9E-06 & 1.97 & $2.4 \mathrm{E}-05$ \\
\hline${ }^{233} \mathrm{U}$ & $6.0 \mathrm{E}-01$ & 1.7E-06 & 1.78 & 2.1E-06 \\
\hline${ }^{234} \mathrm{U}$ & $2.3 E+02$ & 6.7E-04 & 1.71 & 1.3E-03 \\
\hline${ }^{235} \mathrm{U}$ & 1.1E+01 & 3.1E-05 & 1.66 & 9.6E-05 \\
\hline${ }^{236} \mathrm{U}$ & $1.2 \mathrm{E}+01$ & $3.5 \mathrm{E}-05$ & 2.03 & 1.1E-05 \\
\hline${ }^{238} \mathrm{U}$ & $3.7 E+02$ & 1.1E-03 & 1.57 & $6.8 \mathrm{E}-04$ \\
\hline${ }^{237} \mathrm{~Np}$ & $8.9 \mathrm{E}+00$ & 2.6E-05 & 1.80 & $1.4 \mathrm{E}-03$ \\
\hline${ }^{238} \mathrm{Pu}$ & $1.9 \mathrm{E}+01$ & 5.7E-05 & 1.84 & 1.7E-05 \\
\hline${ }^{239} \mathrm{Pu}$ & $8.0 \mathrm{E}+01$ & 2.3E-04 & 1.56 & 3.8E-04 \\
\hline${ }^{240} \mathrm{Pu}$ & $1.6 \mathrm{E}+01$ & 4.7E-05 & 1.60 & 7.5E-05 \\
\hline
\end{tabular}


Table 4

Closure Inventory Estimate for the U-3ah/at Disposal Cell Projected from Inventory Data through FY 2005

(continued)

\begin{tabular}{|c|c|c|c|c|}
\hline Nuclide & $\begin{array}{c}\text { Geometric } \\
\text { Mean } \\
(\mathbf{C i})\end{array}$ & $\begin{array}{c}\text { Geometric } \\
\text { Mean (Ci/m }{ }^{3}\end{array}$ & $\begin{array}{c}\text { Geometric } \\
\text { Standard } \\
\text { Deviation } \\
(\text { Ci) }\end{array}$ & $\begin{array}{c}\text { Geometric } \\
\text { Mean of the } \\
\text { Sum of } \\
\text { Fractions }\end{array}$ \\
\hline${ }^{241} \mathrm{Pu}$ & $7.2 \mathrm{E}+01$ & $2.1 \mathrm{E}-04$ & 1.62 & $1.5 \mathrm{E}-05$ \\
\hline${ }^{242} \mathrm{Pu}$ & $2.8 \mathrm{E}-03$ & $8.2 \mathrm{E}-09$ & 1.65 & $1.3 \mathrm{E}-08$ \\
\hline${ }^{244} \mathrm{Pu}$ & $2.4 \mathrm{E}-11$ & $7.0 \mathrm{E}-17$ & 2.08 & NL \\
\hline${ }^{241} \mathrm{Am}$ & $1.4 \mathrm{E}+01$ & $4.1 \mathrm{E}-05$ & 1.55 & $8.5 \mathrm{E}-05$ \\
\hline${ }^{242 \mathrm{~m}} \mathrm{Am}$ & $7.6 \mathrm{E}-03$ & $2.2 \mathrm{E}-08$ & 1.86 & NL \\
\hline${ }^{243} \mathrm{Am}$ & $1.7 \mathrm{E}-02$ & $4.9 \mathrm{E}-08$ & 1.74 & $2.6 \mathrm{E}-07$ \\
\hline${ }^{243} \mathrm{Cm}$ & $1.1 \mathrm{E}-04$ & $3.3 \mathrm{E}-10$ & 1.83 & NL \\
\hline${ }^{244} \mathrm{Cm}$ & $4.0 \mathrm{E}-01$ & $1.2 \mathrm{E}-06$ & 1.55 & $5.4 \mathrm{E}-09$ \\
\hline${ }^{245} \mathrm{Cm}$ & $1.6 \mathrm{E}-02$ & $4.8 \mathrm{E}-08$ & 1.92 & NL \\
\hline${ }^{246} \mathrm{Cm}$ & $2.8 \mathrm{E}-03$ & $8.1 \mathrm{E}-09$ & 1.90 & NL \\
\hline${ }^{247} \mathrm{Cm}$ & $2.3 \mathrm{E}-09$ & $6.9 \mathrm{E}-15$ & 2.07 & NL \\
\hline${ }^{248} \mathrm{Cm}$ & $2.0 \mathrm{E}-22$ & $1.0 \mathrm{E}-20$ & 2.14 & NL \\
\hline${ }^{249} \mathrm{Cf}$ & $1.1 \mathrm{E}-07$ & $3.1 \mathrm{E}-13$ & 1.90 & NL \\
\hline${ }^{250} \mathrm{Cf}$ & $7.3 \mathrm{E}-08$ & $2.1 \mathrm{E}-13$ & 2.04 & $\mathrm{NL}$ \\
\hline${ }^{251} \mathrm{Cf}$ & $6.6 \mathrm{E}-03$ & $1.9 \mathrm{E}-08$ & 2.10 & $\mathrm{NL}$ \\
\hline $\mathrm{Total}$ & $4.2 \mathrm{E}+05$ & $1.2 \mathrm{E}+00$ & & $\mathbf{2 . 0 E}-02$ \\
\hline
\end{tabular}

Notes:

$\mathrm{NL}$ No waste concentration limit.

Source:

Bechtel Nevada, 2006a. Fiscal Year 2005 Annual Summary Report for the Area 3 and Area 5

Radioactive Waste Management Sites at the Nevada Test Site, Nye County, Nevada. Las

Vegas, Nevada. January 24, 2006. Unbound letter report. 10 pages. 
Table 5

Closure Inventory Estimate for the U-3bh Disposal Cell Projected from Inventory Data through FY 2005

\begin{tabular}{|c|c|c|c|c|}
\hline Nuclide & $\begin{array}{l}\text { Geometric } \\
\text { Mean } \\
\text { (Ci) }\end{array}$ & $\begin{array}{c}\text { Geometric } \\
\text { Mean }\left(\mathrm{Ci} / \mathrm{m}^{3}\right)\end{array}$ & $\begin{array}{c}\text { Geometric } \\
\text { Standard } \\
\text { Deviation } \\
\text { (Ci) }\end{array}$ & $\begin{array}{l}\text { Geometric } \\
\text { Mean of the } \\
\text { Sum of } \\
\text { Fractions }\end{array}$ \\
\hline${ }^{3} \mathrm{H}$ & $2.6 \mathrm{E}+05$ & $4.0 \mathrm{E}+00$ & 2.22 & 2.6E-05 \\
\hline${ }^{14} \mathrm{C}$ & $4.8 \mathrm{E}-02$ & 7.3E-07 & 4.49 & $1.2 \mathrm{E}-5$ \\
\hline${ }^{36} \mathrm{Cl}$ & 2.1E-06 & 5.7E-10 & 104.78 & 1.4E-09 \\
\hline${ }^{42} \mathrm{Ar}$ & $9.8 \mathrm{E}-03$ & 1.5E-07 & 2.16 & $\mathrm{NL}$ \\
\hline${ }^{40} \mathrm{~K}$ & 2.1E-02 & 3.2E-07 & 2.36 & $\mathrm{NL}$ \\
\hline${ }^{44} \mathrm{Ti}$ & 2.2E-01 & $3.4 \mathrm{E}-06$ & 2.06 & NL \\
\hline${ }^{60} \mathrm{Co}$ & 3.7E-01 & 5.7E-06 & 1.79 & $\mathrm{NL}$ \\
\hline${ }^{59} \mathrm{Ni}$ & 4.9E-03 & 7.6E-08 & 2.21 & $3.4 \mathrm{E}-10$ \\
\hline${ }^{63} \mathrm{Ni}$ & 3.7E-01 & $5.6 \mathrm{E}-06$ & 1.89 & 8.4E-09 \\
\hline${ }^{79} \mathrm{Se}$ & 3.7E-07 & 4.3E-10 & 172.31 & NL \\
\hline${ }^{85} \mathrm{Kr}$ & 5.7E-05 & 8.1E-09 & 768.92 & NL \\
\hline${ }^{90} \mathrm{Sr}$ & $2.3 E+01$ & $3.5 \mathrm{E}-04$ & 15.46 & 8.7E-06 \\
\hline${ }^{94} \mathrm{Nb}$ & 4.8E-03 & 7.4E-08 & 2.00 & NL \\
\hline${ }^{99} \mathrm{Tc}$ & $3.7 E+00$ & 5.6E-05 & 1.85 & 2.0E-05 \\
\hline${ }^{126} \mathrm{Sn}$ & 2.6E-06 & $5.9 \mathrm{E}-10$ & 1039.68 & 1.4E-08 \\
\hline${ }^{129} I$ & $7.2 \mathrm{E}-03$ & 1.1E-07 & 2.41 & 1.4E-06 \\
\hline${ }^{133} \mathrm{Ba}$ & 1.1E-01 & 1.7E-06 & 2.06 & $\mathrm{NL}$ \\
\hline${ }^{137} \mathrm{Cs}$ & $1.3 E+02$ & $2.0 \mathrm{E}-03$ & 3.53 & $2.2 \mathrm{E}-4$ \\
\hline${ }^{151} \mathrm{Sm}$ & 3.6E-05 & $5.5 \mathrm{E}-10$ & 2.08 & 1.7E-14 \\
\hline${ }^{152} \mathrm{Eu}$ & 1.2E-01 & $1.8 \mathrm{E}-06$ & 1.95 & 1.4E-09 \\
\hline${ }^{154} \mathrm{Eu}$ & $2.4 \mathrm{E}-02$ & 3.7E-07 & 2.57 & $1.1 \mathrm{E}-12$ \\
\hline${ }^{152} \mathrm{Gd}$ & $2.4 \mathrm{E}-15$ & $3.7 \mathrm{E}-20$ & $1.9 E+00$ & $\mathrm{NL}$ \\
\hline${ }^{207} \mathrm{Bi}$ & $6.1 \mathrm{E}-04$ & 9.3E-09 & 2.22 & 3.1E-09 \\
\hline${ }^{210} \mathrm{~Pb}$ & 3.5E-02 & 5.4E-07 & 4.48 & 1.5E-09 \\
\hline${ }^{226} \mathrm{Ra}$ & $9.4 \mathrm{E}-02$ & $1.4 \mathrm{E}-06$ & 4.36 & $1.4 \mathrm{E}-3$ \\
\hline${ }^{228} \mathrm{Ra}$ & $5.1 \mathrm{E}+00$ & 7.8E-05 & 2.17 & $\mathrm{NL}$ \\
\hline${ }^{227} \mathrm{Ac}$ & 7.7E-04 & $1.2 \mathrm{E}-08$ & 13.62 & 4.4E-10 \\
\hline${ }^{228} \mathrm{Th}$ & $4.2 \mathrm{E}+00$ & $6.4 \mathrm{E}-05$ & 2.15 & $\mathrm{NL}$ \\
\hline${ }^{229} \underline{\mathrm{Th}}$ & 7.2E-04 & 1.1E-08 & 2.03 & 1.0E-07 \\
\hline${ }^{230} \mathrm{Th}$ & $2.4 \mathrm{E}+00$ & 3.7E-05 & 2.11 & 1.4E-2 \\
\hline${ }^{232} \mathrm{Th}$ & $7.0 \mathrm{E}+00$ & 1.1E-04 & 2.18 & $4.9 \mathrm{E}-3$ \\
\hline
\end{tabular}


Table 5

Closure Inventory Estimate for the U-3bh Disposal Cell Projected from Inventory Data through FY 2005 (continued)

\begin{tabular}{|c|c|c|c|c|}
\hline Nuclide & $\begin{array}{l}\text { Geometric } \\
\text { Mean } \\
\text { (Ci) }\end{array}$ & $\begin{array}{c}\text { Geometric } \\
\text { Mean }\left(\mathrm{Ci} / \mathrm{m}^{3}\right)\end{array}$ & $\begin{array}{c}\text { Geometric } \\
\text { Standard } \\
\text { Deviation } \\
\text { (Ci) }\end{array}$ & $\begin{array}{l}\text { Geometric } \\
\text { Mean of the } \\
\text { Sum of } \\
\text { Fractions }\end{array}$ \\
\hline \multirow{2}{*}{${ }^{231} \mathrm{~Pa}$} & 1.7E-04 & 2.6E-09 & 2.42 & 6.8E-08 \\
\hline & $3.0 \mathrm{E}-03$ & $6.0 \mathrm{E}-08$ & 92.35 & 2.3E-07 \\
\hline${ }^{232} \mathrm{U}$ & 7.6E-01 & 1.2E-05 & 1.98 & $1.4 \mathrm{E}-05$ \\
\hline${ }^{234} U$ & $8.2 E+00$ & 1.3E-04 & 1.80 & 2.4E-4 \\
\hline${ }^{235} \mathrm{U}$ & 5.8E-01 & 9.0E-06 & 1.75 & 2.8E-05 \\
\hline${ }^{236} \mathrm{U}$ & 8.8E-02 & $1.4 \mathrm{E}-06$ & 4.37 & $4.2 \mathrm{E}-07$ \\
\hline${ }^{238} U$ & $2.8 E+01$ & 4.3E-04 & 2.03 & $2.7 E-4$ \\
\hline${ }^{237} \mathrm{~Np}$ & 1.3E-01 & 2.0E-06 & 11.07 & 1.0E-4 \\
\hline${ }^{238} \mathrm{Pu}$ & $6.3 E+00$ & 9.7E-05 & 2.07 & 3.0E-05 \\
\hline${ }^{239} \mathrm{Pu}$ & $1.8 E+01$ & $2.7 E-04$ & 1.73 & 4.3E-4 \\
\hline${ }^{240} \mathrm{Pu}$ & $2.9 E+00$ & 4.5E-05 & 1.80 & 7.2E-05 \\
\hline${ }^{241} \mathrm{Pu}$ & $1.0 \mathrm{E}+01$ & 1.6E-04 & 1.87 & 1.1E-05 \\
\hline${ }^{242} \mathrm{Pu}$ & 1.1E-03 & 1.7E-08 & 2.22 & 2.7E-08 \\
\hline${ }^{244} \mathrm{Pu}$ & 2.6E-15 & 4.0E-20 & 118.30 & $\mathrm{NL}$ \\
\hline${ }^{241} \mathrm{Am}$ & $2.5 E+00$ & 3.9E-05 & 1.72 & 8.0E-05 \\
\hline${ }^{242 m} \mathrm{Am}$ & 2.0E-04 & 3.1E-09 & 2.89 & $\mathrm{NL}$ \\
\hline${ }^{243} \mathrm{Am}$ & $2.2 \mathrm{E}-04$ & 3.3E-09 & 7.31 & 1.8E-08 \\
\hline${ }^{243} \mathrm{Cm}$ & 9.8E-07 & 3.1E-11 & 51.19 & $\mathrm{NL}$ \\
\hline${ }^{244} \mathrm{Cm}$ & 1.6E-02 & $2.5 E-07$ & 2.87 & 1.1E-09 \\
\hline${ }^{245} \mathrm{Cm}$ & 3.3E-05 & $7.1 \mathrm{E}-10$ & 245.89 & $\mathrm{NL}$ \\
\hline${ }^{246} \mathrm{Cm}$ & 7.6E-06 & $1.8 \mathrm{E}-10$ & 122.85 & $\mathrm{NL}$ \\
\hline${ }^{247} \mathrm{Cm}$ & $5.2 E-13$ & 1.3E-16 & 28298.96 & $\mathrm{NL}$ \\
\hline${ }^{249} \mathrm{Cf}$ & 1.6E-09 & $2.2 \mathrm{E}-12$ & 2.70 & $\mathrm{NL}$ \\
\hline${ }^{250} \mathrm{Cf}$ & 1.6E-09 & 2.1E-11 & 2.27 & NL \\
\hline${ }^{251} \mathrm{Cf}$ & $4.5 \mathrm{E}-07$ & 4.1E-10 & 736.27 & $\mathrm{NL}$ \\
\hline Total & $2.6 E+05$ & $4.0 \mathrm{E}+00$ & & $2.4 \mathrm{E}-02$ \\
\hline $\begin{array}{cc}\text { Notes: } & \\
\text { D } & \text { Dispos } \\
\text { P } & \text { Progen } \\
\text { NA } & \text { Not ava } \\
\text { NL } & \text { No was } \\
\text { Source: } \\
\text { Bechtel Neva } \\
\text { Radioactive } \\
\text { Vegas, Neva }\end{array}$ & $\begin{array}{l}\text { ce preparation } \\
\text { isposed radionu } \\
\text { nuclide not ev } \\
\text { icentration limit } \\
\text { Mana. Fiscal Ye } \\
\text { Management } \\
\text { anury } 24\end{array}$ & $\begin{array}{l}\text { A. } \\
\text { ated in the Area } 3\end{array}$ & $\begin{array}{l}\text { Report for } t \\
\text { e, Nye Cou } \\
0 \text { pages. }\end{array}$ & $\begin{array}{l}3 \text { and Area } 5 \\
\text { ada. Las }\end{array}$ \\
\hline
\end{tabular}


The Area 3 RWMS is currently inactive. The final inventory at closure may change if additional waste is disposed at the Area 3 RWMS. However, the PA/CA maintenance process ensures that inventory projections will be updated periodically and evaluated against the closure performance objectives throughout the operational life of the facility. 


\subsection{MONITORING PROGRAMS}

Routine monitoring data for the entire NTS and off-site areas are summarized annually in reports designed to meet requirements of DOE Order 231.1A, "Environment, Safety and Health Reporting" (DOE, 2003b), and other DOE program needs. The latest published report is Nevada Test Site Environmental Report 2004 (BN, 2005). Site-specific monitoring data for the two NTS RWMS facilities are also summarized in annual reports (e.g., BN, 2005d). Many types of monitoring data are entered in the Bechtel Environmental Integrated Data Management System (BEIDMS) Version 3.8 database (BN, 1999d). There are also investigative programs that provide nonroutine monitoring data, such as the groundwater sampling data collected from selected wells for the Hydrologic Resources Management Program (HRMP) and Underground Test Area (UGTA) Project. These studies provide data for development and validation of various transport models for contaminant sources related to past nuclear experiments.

\subsection{Current Monitoring}

Figures 5 and 6 show the locations of monitoring stations at and near to the Area 3 RWMS. Current monitoring at the RWMSs includes:

- Direct radiation monitoring to confirm that RWMS operations do not result in significant exposure above background levels. Thermoluminescent dosimeters (TLDs) are checked quarterly.

- Air monitoring to confirm that operations do not result in significant radionuclide activity levels above background and to confirm compliance with National Emissions Standards for Hazardous Air Pollutants (NESHAP). Alpha and beta concentrations are checked weekly; tritium is checked biweekly; and gamma, americium, and plutonium are checked monthly. Radon flux measurements are collected from selected operational waste covers at the Area 5 RWMS and the final cover of U-3ax/bl at the Area 3 RWMS as needed to characterize trends.

- Vadose zone monitoring to assess the water balance and evaluate performance of the waste covers. NSTec collects data from the drainage lysimeter and the TDR automated cover vadose zone monitoring system daily at the Area 3 RWMS. The TDR system has two data loggers (West TDR and East TDR) located near the edge of the cover. Each data logger is connected by cables to two strings of eight TDR sensors buried in the cover at approximately 30 -centimeter $(\mathrm{cm})(1-\mathrm{ft})$ intervals down to a depth of approximately $2.4 \mathrm{~m}(8 \mathrm{ft})$.

- Biota monitoring for tritium is conducted periodically as a potential indicator of whether tritium is moving into the near-surface alluvium and through the waste covers; however, movement of animals and the existence of other potential sources of radioactive contaminants in the vicinity of the Area 3 RWMS complicate interpretation.

- Subsidence monitoring at closed waste disposal cells to identify depressions and cracks in the covers early and repair them to prevent development of preferential pathways through the covers.

- Meteorological monitoring to provide data needed to assess the energy and water balance, and estimate potential evapotranspiration (PET) rates. Average, minimum, and maximum air temperatures, humidity, wind speeds, and barometric pressure; and total precipitation are 


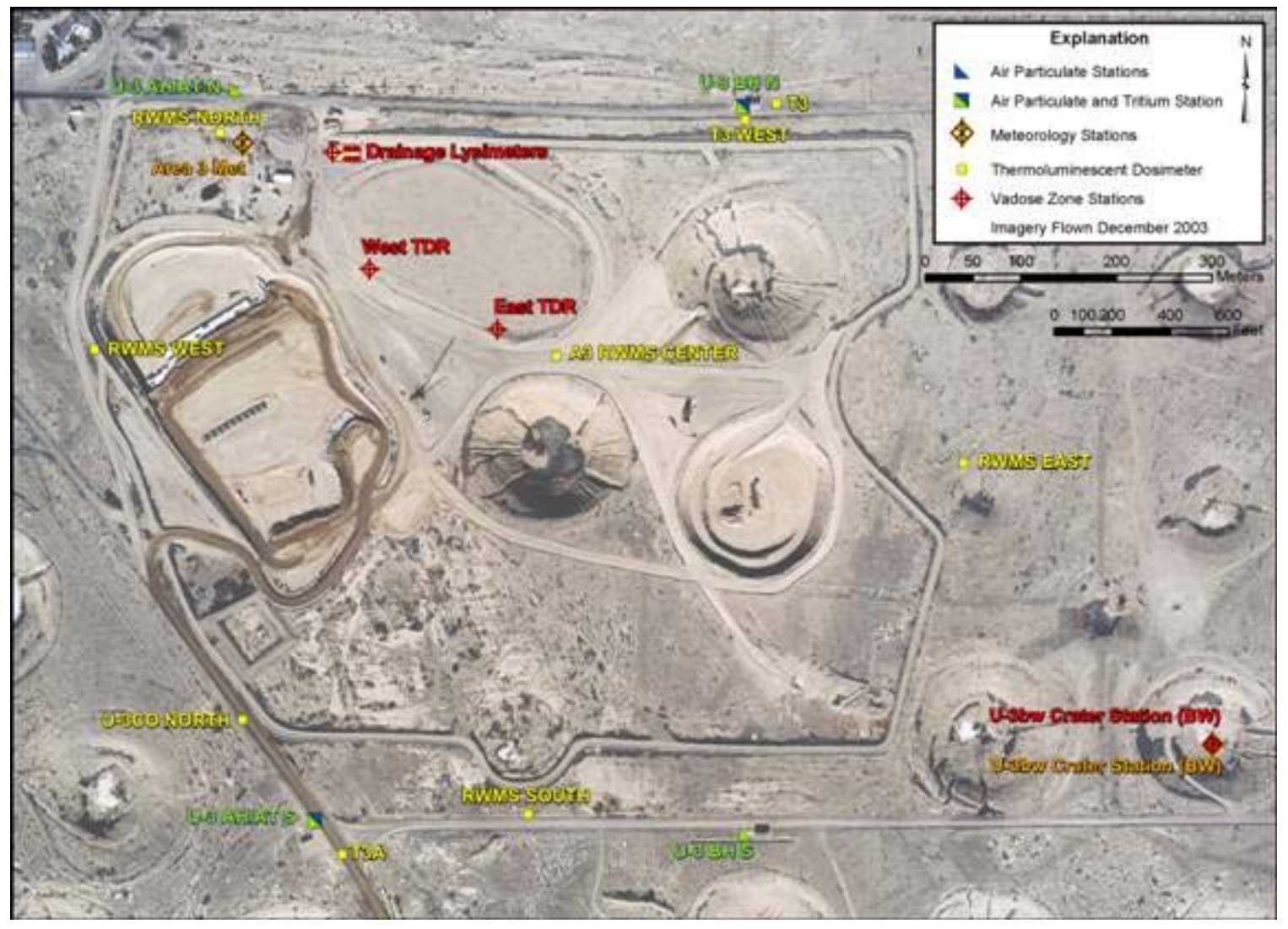

Figure 5

Monitoring Stations at the Area 3 RWMS 


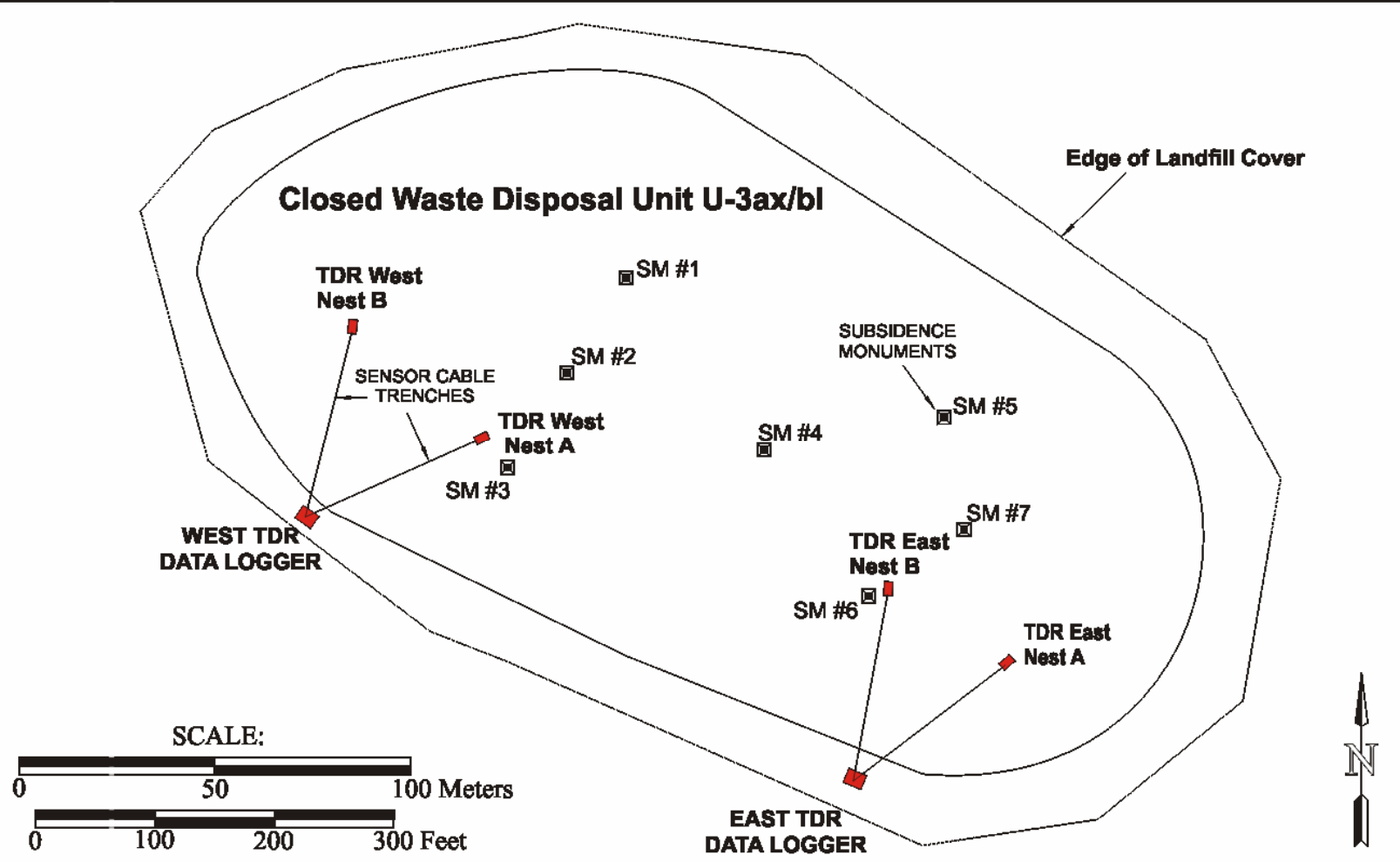

Modified from: NNSANSO, 2001. Closure Report for Corrective Action Unit 110: Areas (sic)3 RWMS U-3ax/bl Disposal Unit, Nevada Test Site, Nevada. DOE/NV-733. Las Vegas, Nevada.

Figure 6

Time-Domain Reflectometry Nests and Subsidence Monitoring Monuments at U-3ax/bl

collected daily. Average air temperature, relative humidity, wind speed, wind direction, barometric pressure, and solar radiation, and total precipitation data are collected hourly.

Site-specific groundwater monitoring is not required for operation of the LLW landfill cells at the Area 3 RWMS under existing regulations. The RCRA permit for the closed LLMW cell, U-3ax/bl, includes a waiver from RCRA groundwater monitoring requirements. Because any contamination from the Area 3 RWMS waste is unlikely to migrate to groundwater within the compliance period due to site conditions, groundwater is considered a highly unlikely exposure pathway. Depth to groundwater is at least $488 \mathrm{~m}(1,600 \mathrm{ft})(\mathrm{BN}, 2005 \mathrm{~d})$. Conservative models of potential vertical groundwater movement indicate that the potential for recharge in the next tens of thousands of years is extremely low (Shott et al., 2000).

Biennially, groundwater across the NTS is tested for gross alpha, gross beta, gamma spectroscopy, and plutonium under the NTS Routine Radiological Environmental Monitoring Plan (RREMP) (BN, 2003b). This annual monitoring includes wells within Yucca Flat, but none are close to the Area 3 RWMS. 
For detailed information on NTS monitoring programs and the relevant DOE orders, federal and state statutes, permits, and agreements, see the latest edition of the RREMP (BN, 2003b). The RREMP covers the specific radiological monitoring requirements and data quality objectives for the NTS. Sections 4.2 through 4.5 cover subsidence, air, direct radiation, and biota radiationexposure monitoring in more detail.

\subsection{Subsidence}

Subsidence evaluations have included a preliminary estimate of potential subsidence at the Area 3 RWMS (Obi et al., 1996) and an alternative evaluation study of methods to mitigate subsidence (Barker, 1997).

Potential subsidence of the landfill surface depends not only on the moisture content, physical properties, and degree of compaction of the soil cover, but also on the structural integrity of the containers, how the containers are layered, the weight of the containers and the soil cover above, and the amount of void space within and around the containers. Potential for subsidence across the Area 3 RWMS landfill cells may vary spatially, reflecting changes in waste types, waste packaging, waste emplacement, and landfill cover operations over time. Other factors related to surface erosion and soil structure, such as the distribution of vegetation and animal burrows, and the development of drainage patterns, could also eventually influence subsidence potential. Operation practices, such as minimizing void space during waste emplacement, are in place to mitigate potential future subsidence at active disposal cells as much as reasonably practicable (BN, 2006c).

The post-closure monitoring program for the closed U-3ax/bl landfill cell includes semiannual elevation surveys at seven monuments in the final landfill cover (Figure 6) and quarterly visual inspections of the site. This monitoring ensures that cracks and depressions, expected as buried waste settles, are identified and repaired in a timely manner to mitigate erosion and development of preferential pathways through the waste covers. Cracks or settling greater than $15 \mathrm{~cm}$

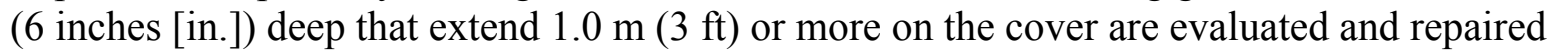
within 60 days of detection in accordance with the Hazardous Waste Permit HW0021 (NDEP, 2005). When such features are observed, their locations are recorded using a Global Positioning System unit and operations personnel are informed to take corrective action. Location of observed subsidence features and corrective actions are presented in post-closure monitoring reports, as well as in the annual waste management monitoring reports.

The latest published monitoring report is for the July 2004 to June 2005 period (BN, 2005f). The east edge of the $U-3 a x / b 1$ cover has been repaired several times since 2003. An area of cracks discovered on the southeast edge of the cover in March 2004 has been repaired twice. Minor cracks and depressions were expected at this waste cell as the material settled. The coverspecific monitoring plan is designed to ensure prompt maintenance of the cover at this site.

In 2005, biologists trapped small mammals and relocated them away from the U-3ax/bl cover area to reduce burrowing. The relocation appears to have been successful; biologists observed fewer animal burrows on a subsequent inspection. Eight semiannual re-surveys of the seven monuments in the final landfill cover indicate that there has been no significant change in land 
surface elevation since the baseline survey in December 2000 (BN, 2005f). The effectiveness of the subsidence monitoring at the Area 3 RWMS is evaluated periodically as part of the PA process.

Currently, there are no plans to implement subsidence monitoring of the operational covers at the active waste disposal cells U-3ah/at and U-3bh (personal communication, Clark to Wieland, 2006). However, when these waste disposal cells are closed in the future, subsidence monitoring may be included in the post-closure monitoring during the period of active institutional control.

U-3ah/at and U-3bh are newer cells with a different mix of waste types and container types than U-3ax/bl. Emplacement and stacking practices have changed over time, reducing potential void spaces. Although eventually the final covers on U-3bh and U-3ah/at are also likely to have some minor differential subsidence, the degree and patterns of subsidence may be different from $\mathrm{U}-3 \mathrm{ax} / \mathrm{bl}$. The proposed monolayer cover design will accommodate some subsidence, and the maintenance and monitoring plan may be tailored to cell-specific conditions.

\subsection{Air Quality}

There have never been any air quality regulatory compliance issues at the Area 3 RWMS or the NTS (personal communication, Grossman to Wieland, 2006). Air quality monitoring results to date indicate that Area 3 RWMS waste management activities do not appear to have contributed to the ambient low levels of radionuclides present in Yucca Flat air from the resuspension of particulates from past nuclear testing and from natural sources.

The NTS-wide air monitoring program provides long-term air quality trends. BN (2005h) summarizes the regulatory framework, 2004 annual results, and summarizes annual averages over time to evaluate trends. The NTS conducts radiological air monitoring on and off the NTS to document compliance with the Clean Air Act NESHAP (Title 40 CFR Part 61 Subpart H) (CFR, 1996a) and with DOE Order 5400.5, "Radiation Protection of the Public and the Environment" (DOE, 1993). The NTS also monitors and maintains compliance with the National Ambient Air Quality Standards for six criteria pollutants including particulates. Fugitive dust is managed through best management practices and periodic monitoring. For several years, the nearest air quality monitoring station to the Area 3 RWMS was located in Area 1 at Buster-Jangle Y (BJY).

NNSA/NSO's contractor monitors air quality at four radiological air monitoring stations (U-3ah/at N, U-3bh N, U-3ah/at S, and U-3bh S) installed in the immediate vicinity of the Area 3 RWMS to provide site-specific data for waste operations compliance assessments (the PA and $\mathrm{CA}$ ). Figure 5 shows the station locations. These local stations have not been in operation as long as the regional NTS network, but provide adequate data to characterize air quality in the immediate vicinity of the site. The stations are equipped to collect particulates and atmospheric moisture.

The annual Waste Management Monitoring Reports (WMMRs) document methods, any equipment modifications through time, and annual results for the RWMS monitoring sites. Earlier air data were reportedly published in a series of annual Ecosystem Monitoring Reports (e.g., "1999 Ecosystem Monitoring Report” by BN [1999c]). 
Air quality data have also been reported in detail in the Annual Site Environmental Report (ASER) reports (e.g., BN, 2003c) (the predecessor to the current Nevada Test Site Environmental Report [NTSER] series) (e.g., BN, 2005h). In addition to annual written reports, air quality data are entered in BEIDMS, the Oracle-based relational database developed by BN for management of NTS environmental data (BN, 1999d).

NNSA/NSO's contractor also monitors radon flux density through landfill covers to assess compliance with the DOE performance objectives under DOE Order 435.1 (2001c), and with the regulatory limit for radon emissions from DOE facilities (Title 40 CFR 61, Subpart Q) (CFR, 1996a), which is 20 picoCuries per square meter per second $\left(\mathrm{pCi} / \mathrm{m}^{2} / \mathrm{s}\right)(\mathrm{BN}, 2005 \mathrm{~d})$. The PA assesses compliance of the Area 3 RWMS facility with this limit for exposure of a member of the public for the projected 1,000-year compliance period after landfill closure. Because radon is a common, naturally occurring radionuclide, comparisons of radon flux measurements at selected landfill cover locations and off-site background locations help determine if any of the radon measured in air is potentially attributable to the waste source.

Some of the figures in this section are graphs of average annual data reproduced from the annual NTSER. These graphs indicate the "CL" level. The CL is the NESHAP concentration level for environmental compliance. The NESHAP CL is more conservative or equal to the derived concentration guide standard under DOE Order 5400.5 (1993). Note that data collected from only six critical receptor samplers at locations on the NTS approved by the EPA are used to determine NTS compliance with the NESHAP average annual dose limit to the public of 10 milliroentgen equivalent man per year (mrem/yr) (BN, 2005h). Data from the many other NTS air monitoring stations (including the site-specific ones at the RWMSs) are used to monitor local trends, assess background, and indicate if there are any unplanned releases. Although the stations are not individual points of compliance for NESHAP, comparison of individual station results to the NESHAP CL (or to 10 percent of the CL) is often used as an indicator of potential local problems, and may trigger further investigation. For further details on NTS air monitoring, how results are presented in the annual reports, air quality compliance determination, and data quality objectives, see the latest NTSER (BN, 2005h) and WMMR (BN, 2005d).

\subsubsection{Tritium}

EPA began monitoring air quality for tritium at the NTS and off site of the NTS in 1972, at the same time that monitoring for noble gases was implemented. NTS monitoring by the DOE management and operations (M\&O) contractor, at that time Reynolds Electrical \& Engineering Co., Inc. (REECo), began in September 1977, after EPA detected tritium on the NTS. There was no regulatory requirement for implementing this monitoring. Tritium monitoring may have been implemented later than other air monitoring programs because it is less hazardous than the other types of radionuclides released during nuclear tests (personal communication, Grossman to Wieland, 2006). The BJY monitoring station in Area 1 was the nearest sampling site to the Area 3 RWMS until the Area 3 RWMS stations were established.

Air water vapor tritium sources at the NTS include tritium transpired by plants and evaporated from soil in the vicinity of past nuclear tests, from evaporation ponds receiving tritiated water pumped from contaminated wells and tunnels, and from LLW burial sites (BN, 2005h).

Researchers collect atmospheric moisture samples over two-week periods and analyze them for tritium. Routine monitoring for tritium at the Area 3 RWMS was discontinued in 1997 because 
results through 1997 had indicated no detectable airborne tritium. "However, due to recent and possible future disposal of tritium sources at the Area 3 RWMS, bi-weekly sampling for atmospheric moisture was begun at U-3ah/at S and U-3bh N (Figure 5) on November 8, 2004" (BN, 2005d).

Mean tritium levels for the 2004 samples collected at the Area 3 RWMS monitoring station are summarized in Table 6 below. In 2004, 26 samples were analyzed from BJY and four samples each were analyzed from U-3ah/at S and U-3bh N. The mean detected concentrations found near the Area 3 RWMS were a fraction of a percent of the NESHAP CL for environmental compliance, and significantly lower than tritium levels detected at Sedan N in Area 10 and the Schooner site in Area 20 of the NTS. See BN (2005h) for further details. The tritium concentrations found near the Area 3 and Area 5 RWMSs are also below the DOE-derived concentration guide for tritium, which is the concentration of the radionuclide in air that could be inhaled for one year and not exceed the DOE primary radiation standard to the public of $100-\mathrm{mrem} / \mathrm{yr}$ effective dose equivalent (BN, 2005d).

Figure 7 shows long-term mean annual tritium trends over time. The NTS Administrative Area 1 data (line labeled A1) reflects results at the BJY monitoring station and is most representative of tritium levels at Yucca Flat.

Table 6. Tritium-2004 Mean Analytical Results

\begin{tabular}{|c|c|}
\hline Location & $\begin{array}{c}{ }^{3} \mathrm{H} \\
(p \mathrm{Ci} / \mathrm{ml})\end{array}$ \\
\hline BJY & $1.32 \mathrm{E}-6$ \\
\hline U-3ah/at N & NA \\
\hline U-3ah/at S & $<M D C$ \\
\hline U-3bh N & $<M D C$ \\
\hline U-3bh S & NA \\
\hline $\begin{array}{l}\text { Compliance } \\
\text { Concentration } \\
\text { Limit }\end{array}$ & 1,500 E-6 \\
\hline \multicolumn{2}{|l|}{$\begin{array}{l}\text { Notes: } \\
\text { MDC Minimum }\end{array}$} \\
\hline \multicolumn{2}{|c|}{$\begin{array}{l}\text { Bechtel Nevada, 2005. Nevada Test Site } \\
\text { Evironmental Report 2004. } \\
\text { DOE/NV/11718--1080. Las Vegas, Nevada. } \\
\text { October 2005. }\end{array}$} \\
\hline
\end{tabular}




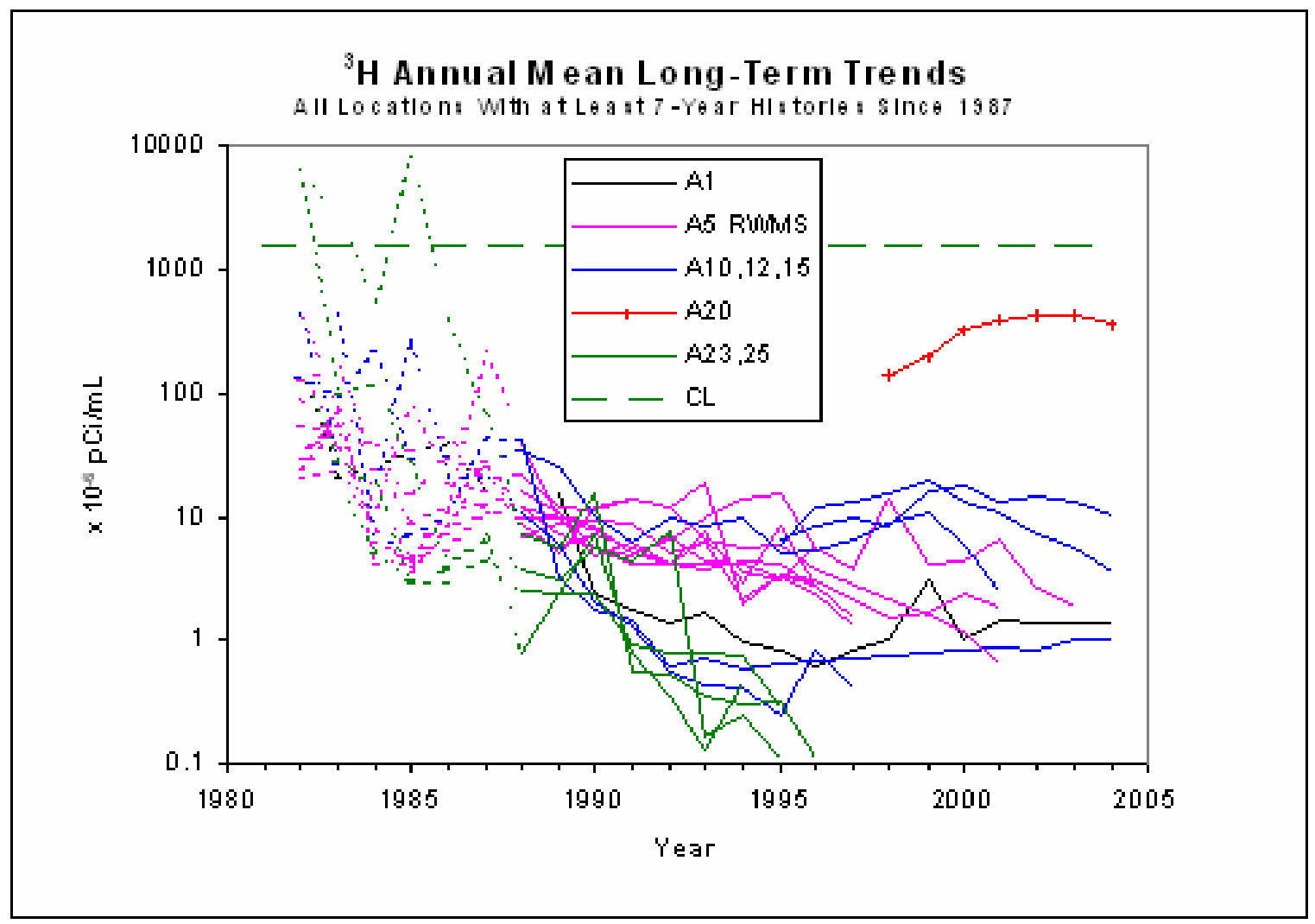

Figure 7. Mean Annual Tritium in Air Moisture Samples. (Source: Bechtel Nevada, 2005. Nevada Test Site Environmental Report 2004. DOE/NV/11718--1080. Las Vegas, Nevada. October 2005. Page 3-16.)

\subsubsection{Particulates}

Weekly samples of airborne particulates are collected on filters and screened for gross alpha and gross beta radioactivity. NSTec analyzes monthly composites of the weekly samples from each station by gamma spectroscopy for gamma-emitting radioactivity and by radiochemical analyses for americium and plutonium (BN, 2005d). Uranium analysis is not part of the regular monitoring suite at the Area 3 RWMS. Air samples from other parts of the NTS where depleted uranium ordnances have been used are analyzed for uranium isotopes (BN, 2005h).

Radionuclide particulate concentrations in air samples at the NTS are attributed to the resuspension of legacy contamination in surface soils from historic nuclear testing. In 2004, the latest published data, the concentrations of man-made radionuclides in the air on the NTS were all well below the federal regulatory limits (BN, 2005h). Because the Area 3 RWMS is in an area with impacted soils from many past tests, the levels of radionuclides in the air at the Area 3 RWMS stations are higher than some of the other monitoring areas of the NTS farther from test areas, although still very low compared to air quality regulatory requirements. 
$\mathrm{BN}$ (2005h) predicts that in the absence of further nuclear testing, radioactivity levels will eventually decrease. Levels of ${ }^{239+240} \mathrm{Pu}$ in air have declined at the NTS over the past 30 years (see Figure 8). ${ }^{241} \mathrm{Am}$ is a daughter product of ${ }^{241} \mathrm{Pu}$ and has a relatively long half-life compared to ${ }^{241} \mathrm{Pu}$. Consequently, concentrations of ${ }^{241} \mathrm{Am}$ in NTS soils (and consequently air) are expected to slowly gradually increase over the next 80 years, then decline (BN, 2005h).

Figure 8 compares highest annual mean ${ }^{239+240} \mathrm{Pu}$ monitoring data for various areas of the NTS. These are the peak concentrations for each area group. The solid black line represents results from Administrative Areas 1 and 3, which reflect air quality conditions in the central Yucca Flat sub-basin, a portion of the NTS where there is significant residual radioactive soil contamination from historic testing. Nuclear testing at the NTS ended in 1992. Note that this figure presents annual averages of many measurements. The figure does not indicate the method minimal detection concentration limits or distinguish the mean data points that fall below the mean method reporting limits.

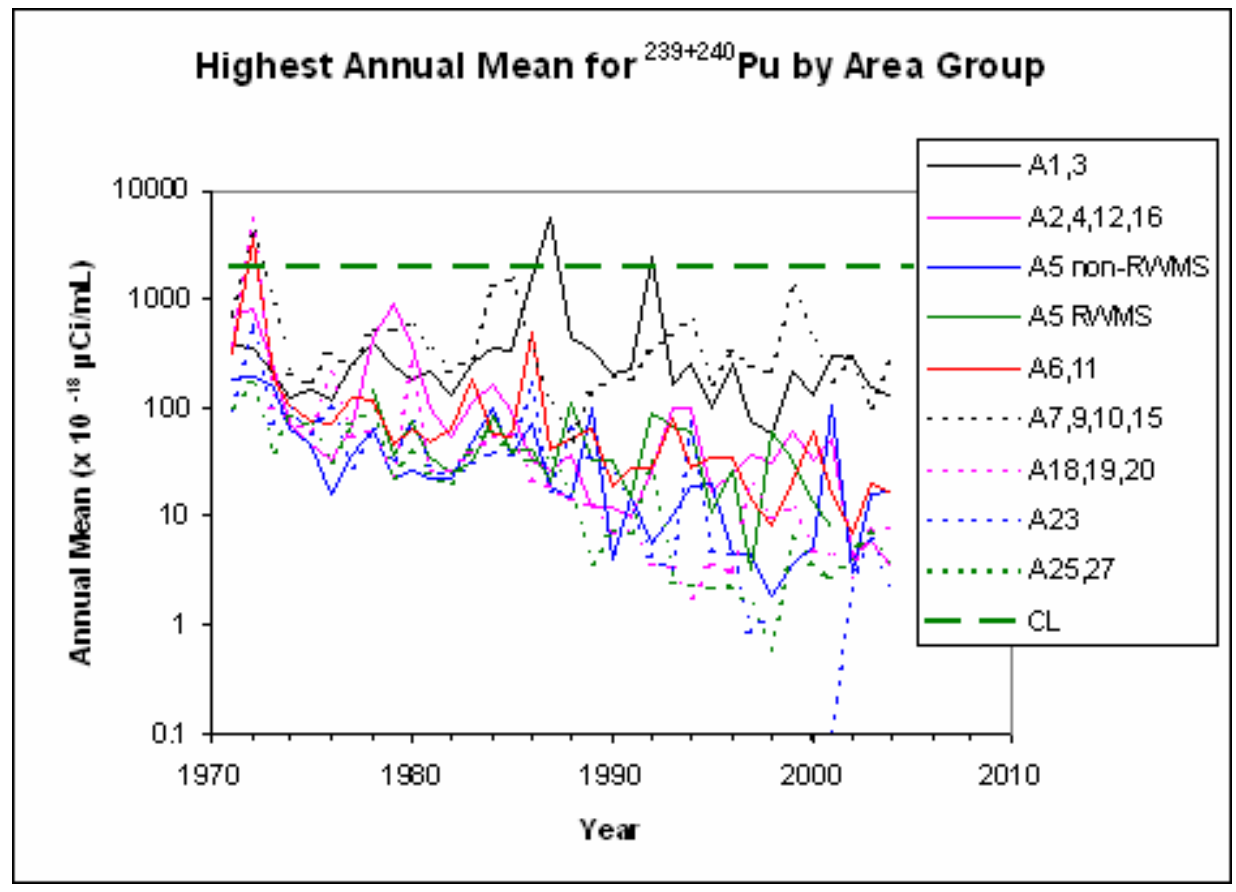

Figure 8. Highest Annual Mean Plutonium in Air Samples (Source: Bechtel Nevada, 2005. Nevada Test Site Environmental Report 2004. DOE/NV/11718--1080. Las Vegas, Nevada. October 2005. Page 3-11.)

Figure 9 shows long-term trends in average annual mean ${ }^{239+240} \mathrm{Pu}$ for monitoring stations that had over 14 years of history as of 2004. This is more representative of average conditions at the NTS. This graph also shows that the areas with residual soil contamination have higher measured air concentrations than other parts of the NTS. 


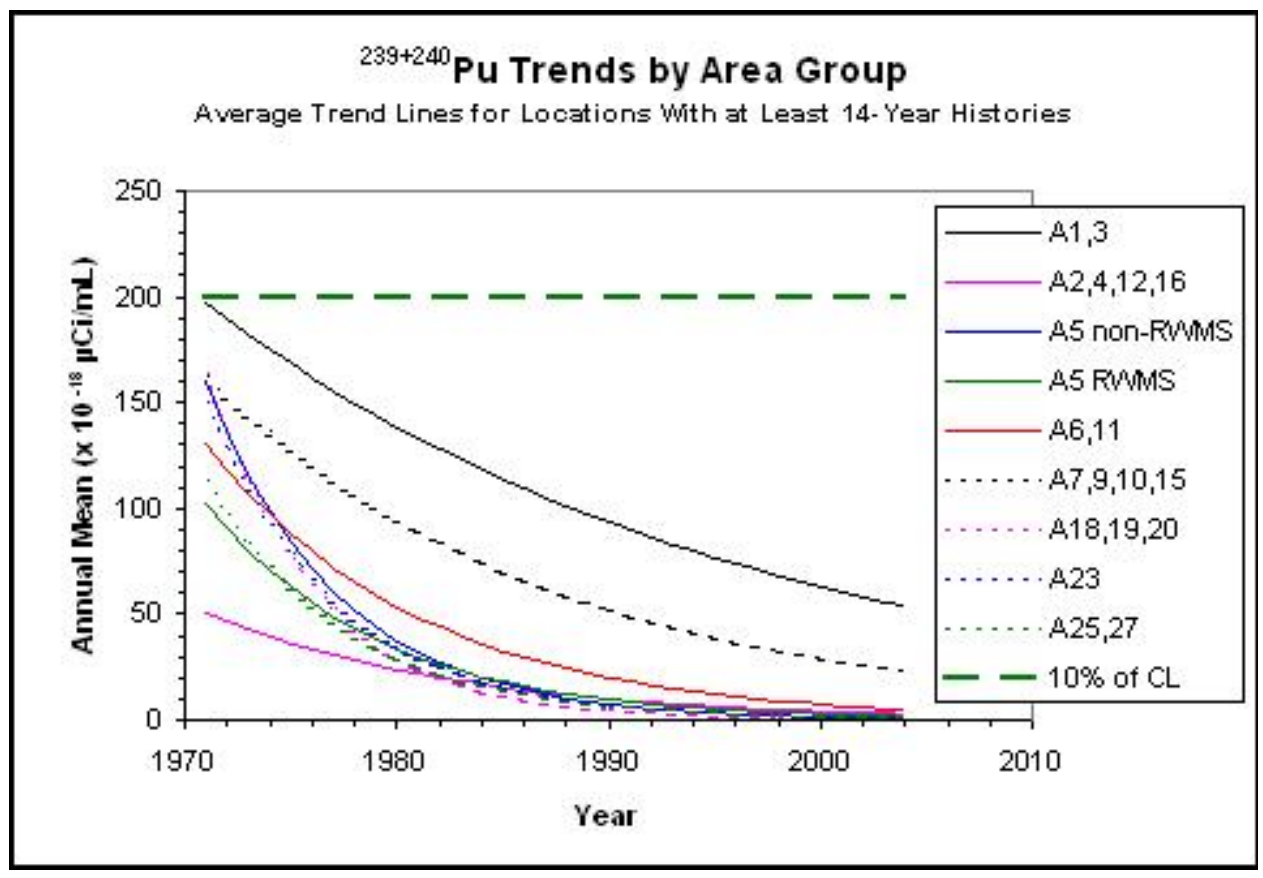

Figure 9. Average Trends Plutonium in Air Samples. (Source: Bechtel Nevada, 2005. Nevada Test Site Environmental Report 2004. DOE/NV/11718--1080. Las Vegas, Nevada. October 2005. Page 3 12.)

Mean annual results for the 2004 monthly samples are presented in Table 7. The 2005 data had not been compiled yet at the time of preparation of this report. $\mathrm{Cs}-137\left({ }^{137} \mathrm{Cs}\right)$ was below the minimum detection limits for all samples. The mean ${ }^{238} \mathrm{Pu}$ concentration from each station was below the mean minimum detection limit, although there were a few low detections in monthly samples over the year. The maximum detectable concentration of ${ }^{238} \mathrm{Pu}$ in air at the Area 3 RWMS in 2004 was less than 1 percent of the compliance concentration limit (BN, 2005h).

There are no regulatory limits for gross alpha and gross beta radioactivity in air samples because these ranges capture naturally occurring radioisotopes as well as regulated man-made ones. However, weekly monitoring may provide an early warning of potential change of conditions.

Five locations at the NTS coinciding with areas of impacted soil from historic testing, including U-3ah/at N and U-3bh N, have consistently had higher levels of gross alpha and gross beta activity compared to other areas of the test site. No increasing trends in gross alpha and gross beta radioactivity have been observed at any monitoring station at the NTS (BN, 2005h). The background activity in air samples is attributable to past nuclear experiments. 
Table 7. Radioactive Particulates 2004 Mean Analytical Results

\begin{tabular}{|l|c|c|}
\hline \multicolumn{1}{|c|}{ Location } & $\begin{array}{c}{ }^{241} \mathrm{Am} \\
(\boldsymbol{\mu C i / m l})\end{array}$ & $\begin{array}{c}{ }^{239+240} \mathrm{Pu} \\
(\boldsymbol{\mu C i} / \mathbf{m l})\end{array}$ \\
\hline BJY & $7.95 \mathrm{E}-18$ & $56.15 \mathrm{E}-18$ \\
\hline U-3ah/at N & $12.79 \mathrm{E}-18$ & $89.47 \mathrm{E}-18$ \\
\hline U-3ah/at S & $20.58 \mathrm{E}-18$ & $119.52 \mathrm{E}-18$ \\
\hline U-3bh N & $14.05 \mathrm{E}-18$ & $83.73 \mathrm{E}-18$ \\
\hline U-3bh S & $8.57 \mathrm{E}-18$ & $40.79 \mathrm{E}-18$ \\
\hline $\begin{array}{l}\text { Compliance } \\
\text { Concentration } \\
\text { Limit }\end{array}$ & $1,900 \mathrm{E}-18$ & $2,000 \mathrm{E}-18$ \\
\hline $\begin{array}{l}\text { Source: } \\
\text { Bechtel Nevada, 2005. Nevada Test Site Environmental } \\
\text { Report 2004. DOE/NV/ 11718--1080. Las Vegas, } \\
\text { Nevada. October 2005. }\end{array}$ \\
\hline
\end{tabular}

\subsubsection{Radon}

Radon flux monitoring at landfill covers and background areas provides an indication of whether radon from waste is migrating to the atmosphere and adding to the natural background levels of radon in the environment. RWMS waste management activities do not appear to have significantly affected radon levels at the NTS, based on monitoring results to date (see past annual WMMRs). All radon flux measurements at both RWMSs were at least five times lower than the $20 \mathrm{pCi} / \mathrm{m}^{2} / \mathrm{s}$ regulatory limit and flux rates from the covers are not higher than those from undisturbed or control locations (written communication, Hudson to Wieland, 2006).

Pit P01U of the Area 5 RWMS has been the primary focus of radon flux monitoring at the NTS RWMSs to date because this disposal cell has had the highest inventory of radium. Performance of the operational cover at $\mathrm{P} 01 \mathrm{U}$ is indicative of the potential performance of similar monolayer soil covers at other waste disposal cells. Radon flux was measured with varying frequency at Pit P01U in 1999 through 2005 to characterize radon flux through the covers and to support interpretation of air monitoring data.

Radon flux was measured at the cover of U-3ax/bl of the Area 3 RWMS in 1999 and 2003. In March 1999, all radon flux measurements at the Area 3 and Area 5 RWMS operational covers and background locations were less than $3 \mathrm{pCi} / \mathrm{m}^{2} / \mathrm{s}$, which is significantly less than the $20 \mathrm{pCi} / \mathrm{m}^{2} / \mathrm{s}$ performance objective under DOE Order 435.1 (2001c). A summary of procedures and results are presented in the 1999 WMMR (BN, 2000). In 2000, 2001, 2002, and 2005, radon flux was measured only at P01U of the Area 5 RWMS. All measurements met the performance objective (BN, 2000; BN, 2002b; BN, 2004a; and written communication, Hudson to Wieland, 2006).

In November 2003, BN researchers measured radon flux at an array of 24 locations on the final cover of closed waste disposal cell U-3ax/bl and at six locations at a background site along the CC Road, about $1.7 \mathrm{~km}$ (1 mi) east of the Area 3 RWMS. In December 2003, radon flux 
similarly was measured at P01U and a background location $0.5 \mathrm{~km}(0.3 \mathrm{mi})$ west of the Area 5 RWMS. Statistical analysis of the results at these sites indicated no significant difference between the average radon flux at the background locations and the flux rates within the RWMSs. The radon fluxes measured at both RWMS sites and background locations were all below $1.7 \mathrm{pCi} / \mathrm{m}^{2} / \mathrm{s}$, which is well below the $20 \mathrm{pCi} / \mathrm{m}^{2} / \mathrm{s}$ performance objective of DOE Order 435.1. Radon concentrations in air were not monitored in 2003 because the radon flux measurements at the covers demonstrated that radon was not migrating upward through the covers from the waste. BN concluded that radon concentrations in air at both sites had been well characterized (BN, 2004a).

In 2004, radon flux was monitored only at the Area 5 RWMS. The north end of P13U was monitored as well as the cover of P01U. "All radon flux measurements are at least five times lower than the regulatory limit and the flux rates from waste caps are not higher than those from undisturbed or control locations" (BN, 2005d).

\subsection{Direct Radiation}

Information for this section is principally derived from the 2004 WMMR (BN, 2005d). Quarterly, a DOE contractor measures ionizing radiation from both natural and man-made sources through a network of TLDs. Nine TLD stations are within or very near the Area 3 RWMS. Figure 5 shows the locations.

The results from TLD stations at the Area 3 RWMS are used to estimate the potential dose to a hypothetical person living year-round at the RWMS, a scenario unlikely to occur while the NTS is maintained as a limited-access federal facility.

Evaluation of any dose contribution from operations at the RWMS is complicated by other sources in the area, particularly surface soil with residual radionuclides from past nuclear testing. The TLD locations designated T3, T3 West, T3A, RWMS-S (or "RWMS South"), and U-3CO N (or "U-3CO North") (see Figure 5), are near to ground zero locations for past atmospheric nuclear experiments (BN, 2005d). Any changes in gamma radiation levels must be carefully evaluated in the context of on-RWMS and near-RWMS activities and operations to determine if these changes may indicate a breach in containment.

Figure 10 summarizes January 1998 through January 2006 exposure rate results from TLD stations located within the Area 3 RWMS boundary; outside of the RWMS, but still within the Yucca Flat test area; and at NTS background locations far from past nuclear tests. Radiation exposure rates at all of these locations are low, less than 2.0 milliroentgens per day ( $\mathrm{mR} /$ day). The lowest exposures were found at the NTS background locations. The highest rates are from a TLD located within the Area 3 RWMS; however, the levels measured at this station are of similar magnitude and only slightly higher than those measured at the other nearby TLD stations in Yucca Flat. The overall declining trend over time in radiation exposure values at the stations located within the RWMS and near to the RWMS may reflect the gradual decay of the residual radioactivity present in Yucca Flat Test Area surface soils. 


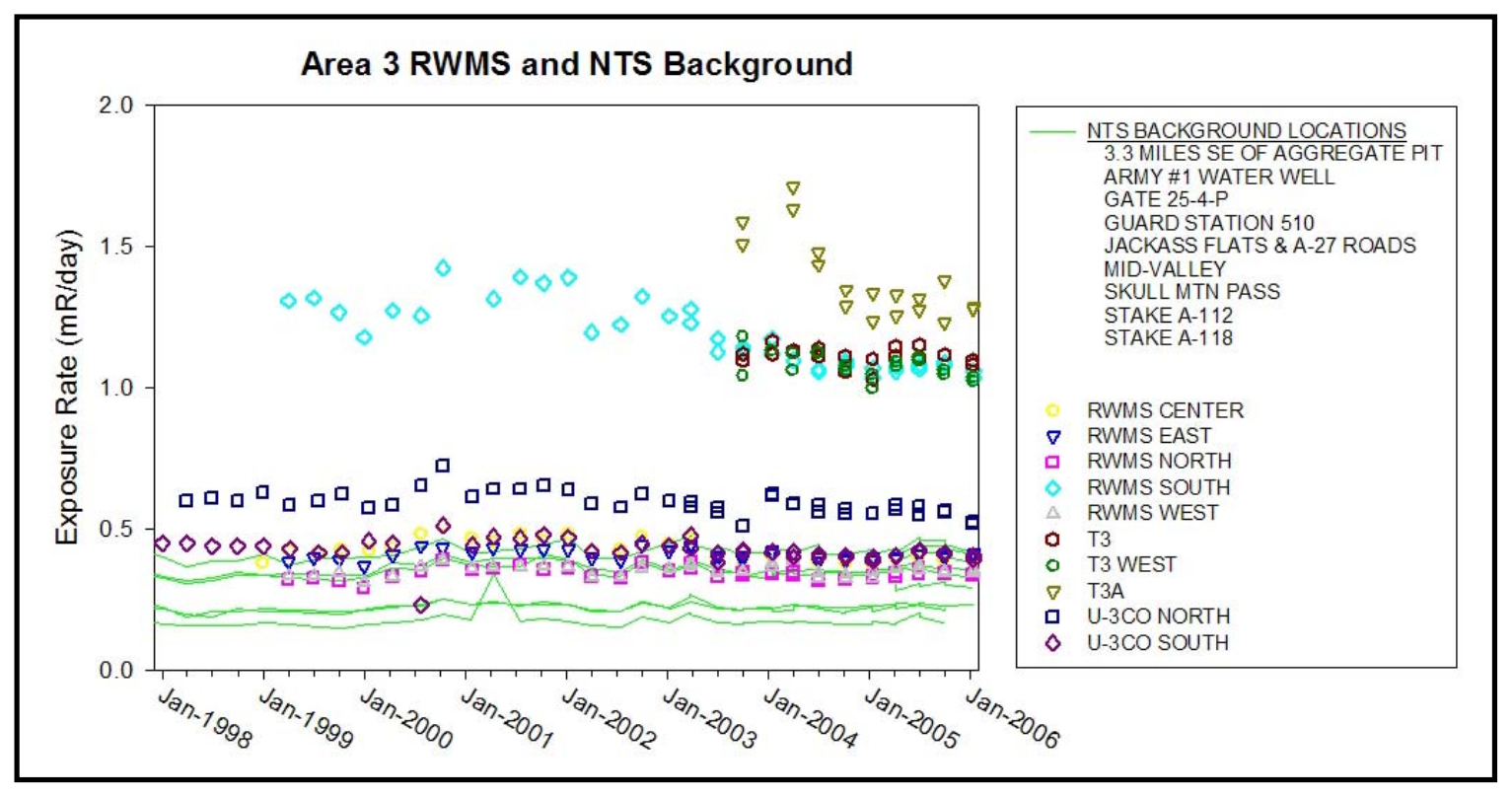

Figure 10. Radiation Exposure Data

The Area 3 RWMS readily and consistently has met the DOE performance objectives set in DOE Order 435.1, "Radioactive Waste Management," which states that LLW disposal facilities shall be sited, designed, operated, maintained, and closed so that a reasonable expectation exists that the dose to representative members of the public shall not exceed $25 \mathrm{mrem} / \mathrm{yr}$ total effective dose equivalent (TEDE) from all exposure pathways, excluding the dose from radon (DOE, 2001c; and $\mathrm{BN}, 2005 \mathrm{~d})$. Radon is a common natural source.

The 2004 average exposure at the RWMS boundaries and inside the RWMSs was $0.36 \mathrm{mR} /$ day and similar magnitude to the average exposure rate at background NTS locations, which was $0.30 \mathrm{mR} /$ day. The net average dose in or at the Area 3 and Area 5 RWMS boundaries is approximately $0.06 \mathrm{mrem} /$ day or $22 \mathrm{mrem} / \mathrm{yr}$ (BN, 2005d). The 2005 calculated average exposure rate was unavailable at the time of preparation of this report, but is expected to be similar. The 2005 data is included in the 2005 WMMR (BN, 2006d). For further information on radiation exposure monitoring, see the annual NTSER (e.g., BN, 2005h) and the annual WMMRs (e.g., BN, 2005d).

\subsection{Biota Radiation}

DOE Order 450.1, "Environmental Protection Program” (DOE, 2003a), includes specific requirements for the protection of natural resources and for evaluation of the potential impacts to biota in the vicinity of DOE activities, including waste management. Details of the monitoring process are specified in the BN Organization Instruction OI-2154.110, "Biota Sampling and Sample Preparation for Animals and Vegetation," for RWMS biota monitoring. The DOE technical standard (DOE-STD-1153-2002, "A Graded Approach for Evaluating Radiation Doses to Aquatic and Terrestrial Biota" [DOE, 2002]) defines conservative protective dose limits. DOE operating policies are designed to ensure that these limits are not exceeded. 
The NTS has a biota monitoring program designed to determine (1) if the absorbed radiation doses to NTS biota are less than the limits set in DOE Order 5400.5 and DOE Standard DOE STD-1153-2002 (< $1 \mathrm{rad}$ per day [rad/day]) for terrestrial plants and aquatic animals, and $<0.1 \mathrm{rad} /$ day for terrestrial animals), and (2) if the potential dose to humans consuming game animals from the NTS is less than the $100 \mathrm{mrem} / \mathrm{yr}$ standard set by DOE Order 5400.5 (1993) (BN, 2005h). The NTS biota monitoring program focuses on areas of the NTS likely to have the highest exposure. There are five sites at the NTS that are routinely sampled at least once every five years. The sites have high known concentrations of radionuclides in soil or surface water and high densities of candidate game animals. The nearest sites to the Area 3 RWMS are Plutonium Valley, about $9 \mathrm{~km}$ (6 mi) away in Area 11; and T2, about $13 \mathrm{~km}$ (8 mi) away in Area 2. Regional monitoring results are presented in the annual NTSER (e.g., BN, 2005h).

Biologists also have collected samples of biota from the Area 3 RWMS. Tritium is the primary radionuclide monitored because of its high mobility as tritiated water. The cycle of plant uptake and transpiration is one of the mechanisms that could transport tritium upward through waste covers and into the atmosphere, in addition to gaseous diffusion, gaseous advection, bioturbation, and evaporation (BN, 2005d). Plant tissue has also been analyzed for alpha- and gamma-emitting radionuclides and strontium-90 $\left({ }^{90} \mathrm{Sr}\right)$.

Plant roots absorb radionuclides from soil water and draw the radionuclides up into the leafy parts of the plant. Potential uptake is affected by root depth, density, and activity; the ability of plants to concentrate radionuclides; plant biomass production and turnover; soil type, climate, and weather. Studies by Sheppard and Evenden (1988), Whicker (1978), and Dreesen and Marple (1979) document the variability in the ability of plants to take up radionuclides. The amount of tritium released into the atmosphere by plant transpiration is affected by several factors including plant size, species, and available moisture.

Vegetation from on and near waste covers, as well as vegetation from control areas far from waste covers, is sampled usually in mid-summer. Timing of the sampling is important because vegetation is forced to remove soil water from greater depths (closer to waste) as surface soils dry out in summer. The plant water is extracted from the vegetation samples by room temperature vacuum distillation and analyzed by liquid scintillation for tritium (BN, 2002b).

If tritium concentrations in vegetation are exceedingly high or if animal burrows on or near waste covers are observed in significant numbers, wild animals and soil from animal burrows may be sampled. Vegetation sampling may be limited year to year, depending on rainfall and waste cover operations during operational closure. Biota monitoring data are included in the annual waste management monitoring reports for the Area 3 and 5 RWMSs.

The most recent biota monitoring at the Area 3 RWMS was conducted in 2005. Samples of small animals and plants were collected from 13 sites on the cover of the closed landfill cell U-3ax/bl. Small mammals were trapped on April 13, 2005, and vegetation was sampled on May 24, 2005. Screening for tritium was conducted on individual plant samples prior to compositing samples for analysis. 
Table 8 summarizes the analytical results of the composite samples from the Area 3 RWMS. Concentrations of radionuclides in the composite plant sample from the Area 3 RWMS were below the sample-specific method detection concentration limits for americium-241 $\left({ }^{241} \mathrm{Am}\right)$, plutonium-239+240 $\left({ }^{239+240} \mathrm{Pu}\right)$, plutonium-238 $\left({ }^{238} \mathrm{Pu}\right)$, and ${ }^{90} \mathrm{Sr}$. The control area composite plant sample contained a low level of ${ }^{90} \mathrm{Sr}$.

The composite animal sample from the Area 3 RWMS contained detectable, but very low, activity levels of ${ }^{241} \mathrm{Am},{ }^{239+240} \mathrm{Pu}$, and ${ }^{90} \mathrm{Sr}$ radionuclides. The control area composite animal sample contained a similar level of ${ }^{90} \mathrm{Sr}$ as the Area 3 RWMS animal sample.

As of March 15, 2006, only preliminary tritium analytical results were available for individual plant samples. For the preliminary data, the range of values of tritium detected in plant samples collected from the $\mathrm{U}-3 \mathrm{ax} / \mathrm{bl}$ landfill cover was 75 to 3,171 net picoCuries per liter (pCi/L). Final validated data and interpretation of the biota monitoring data is presented in the 2005 WMMR (BN, 2006d). Both the composite animal sample and the composite plant sample from the Area 3 RWMS had detectable tritium at concentrations higher than the composite biota samples from the control site. The difference between the tritium level in the U-3ax/bl cover composite animal sample and the control area animal sample was much smaller than the difference between the detected concentrations of tritium in the plants samples. The results suggest that there has been some uptake of tritium by plants and animals, but concentrations are not at levels of concern.

Radionuclide concentrations found in the 2005 biota samples were similar to those found in previous sampling periods (BN, 2001, 2002b; and personal communication, Warren to Wieland, 2006). Further information is in the BEIDMS and in the 2005 WMMR (BN, 2006d). 
Table 8. Composite Biota Samples Collected from U-3ax/bl

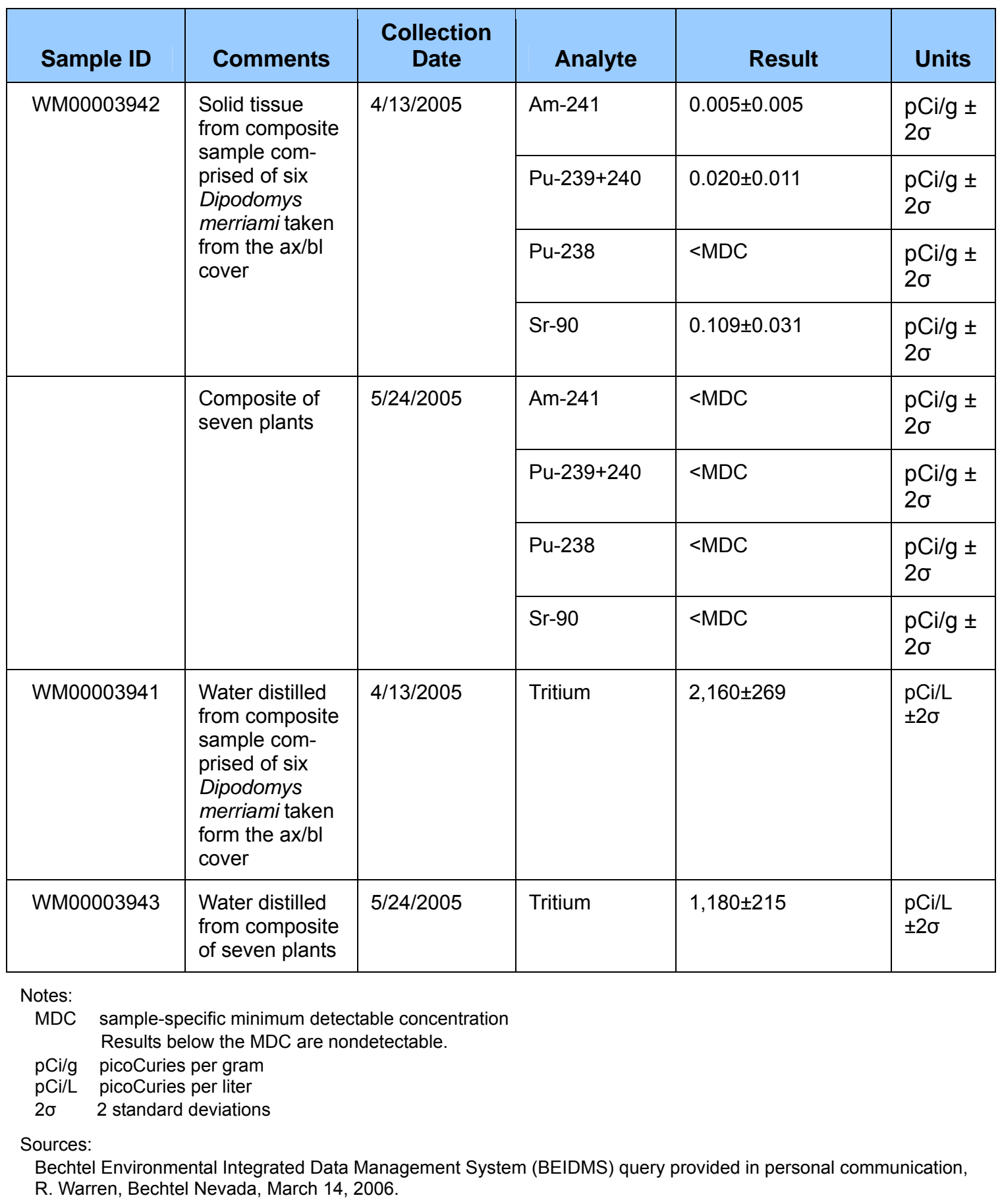

Personal communication, R. Warren, Bechtel Nevada, May 30, 2006.

2005 Waste Management Monitoring Report (BN, 2006d). 


\subsection{NEARBY RADIOLOGICALLY IMPACTED SITES}

Identification of other potential sources of contaminants, particularly radiological contaminants, in the vicinity of the Area 3 RWMS is necessary to:

- $\quad$ evaluate potential impacts from off-site sources,

- $\quad$ ensure that interpretation of monitoring results to confirm performance of the waste containment system takes into account background contaminants,

- $\quad$ ensure worker safety, and

- $\quad$ estimate potential exposure levels for the CA (Section 14.2), which is performed to ensure that the combined effects meet DOE requirements for long-term protection of the public and the environment.

Yucca Flat was the site of 80 atmospheric and 659 underground nuclear tests. Sixty of these nuclear tests were conducted within $400 \mathrm{~m}(1,312 \mathrm{ft})$ of what is now the Area 3 RWMS boundary between 1952 and 1972 (BN, 2005d). The Area 3 RWMS is surrounded by and overlies areas of residual contamination from historic nuclear tests. The nature and boundaries of these residues, the potential for contaminant transport, and the determination of appropriate corrective actions are being actively addressed through several projects within Environmental Management, including the UGTA Project, the Soils Project, the Industrial Sites Project, and the Deactivation and Decommissioning program. These programs have published many reports regarding the contamination sites. Shott et al. (2000) briefly summarizes basic information for the sources considered in the CA. Surface contamination is more likely to be a source factor for future human exposure than the deeply buried underground contamination.

Historic atmospheric nuclear tests at Yucca Flat contaminated surface soils and structures. The last atmospheric test was in 1962. Much of the contamination has decayed away. Cesium-137 $\left({ }^{137} \mathrm{Cs}\right)$ and ${ }^{90} \mathrm{Sr}$ are common residuals (personal communication, Traynor to Wieland, 2006). Europium species residuals are also typical surface contaminants.

Two major ground zeros from atmospheric tests overlap with the current footprint of the Area 3 RWMS. Although there is not much potential for resuspension of radionuclides and the levels do not present a major health risk for workers, the area has radioactivity levels above natural background, so it may be difficult to attribute radionuclides (particularly of cesium, strontium, europium, or plutonium) in biota samples from the landfill cover to the waste. Unless there is a radionuclide type in the landfill waste typically not found in nuclear test residual contamination, contribution from waste operations would likely be indistinguishable from ambient conditions. Air samples might be the most useful monitoring data (personal communication, Lyons to Wieland, 2006).

In the immediate vicinity of some atomic safety tests, which involved detonations without fission, there are localized areas with residual plutonium (personal communication, Traynor to Wieland, 2006). Plutonium from safety shots was dispersed near and within the current Area 3 RWMS footprint. A small area at the north boundary of the Area 3 RWMS east of the entrance was demarcated, fenced, and controlled as a contaminated area. There also used to be an alphaimpacted area at the southwest corner of the Area 3 RWMS, within the berm (personal communication, Lyons to Wieland, 2006). 
Periodic aerial radiological surveys of the NTS and site-specific radiological surveys of work areas provide updated information on the distribution of surface radiological contaminants through time. The likelihood is low that significant amounts of radionuclides would move into the Area 3 RWMS facility through wind and water erosion transport mechanisms (personal communication, Traynor to Wieland, 2006).

The Area 3 RWMS facility is located within a FFACO (NDEP et al., 1996) CAU designated CAU 97-Yucca Flat/Climax Mine. CAU 97 encompasses 720 corrective action sites (CASs) related to nuclear testing within the northeast part of the NTS (see Figure 11). The underground nuclear test sites that formed the collapse sink "craters" within the Area 3 RWMS are designated CASs within CAU 97.

Table 9 summarizes depths and dates of the tests. Figure 12 shows a cross-section of the Area 3 RWMS area and the U-3ah/at and U-3bh waste cell craters with respect to the underground tests, the water table, and the general hydrostratigraphic units.

Postshot drilling program data collected in the 1960s indicate there are radionuclides from the tests in the subsurface. The modern-day distribution of residual contamination from the underground explosions is unknown. The bulk of remaining radiological contamination is likely to be deep within the vadose zone. However, historic data provided by Los Alamos National Laboratory (LANL) staff in a data review of the U-3bh collapse zone for BN (BN, 1996a) suggest that the underground nuclear tests at U-3ah and at U-3bg seeped small amounts of radiation up to the ground surface at the test locations. Consequently, there may be some residual contaminants in shallow alluvium far above these test cavities.

The corrective action investigation for CAU 97-Yucca Flat /Climax Mine is a complex multiyear task in progress. The overall strategy is described in detail in the Corrective Action Investigation Plan (CAIP) (DOE/NV, 2000b). It is unknown if the groundwater directly below the Area 3 RWMS site is impacted by radionuclides from historic testing at Yucca Flat. The tests that formed the craters at the RWMS were above the water table, and have not been targeted for sitespecific groundwater studies to date. Site-specific groundwater investigations for CAU 97 generally have focused on test sites where the detonation occurred below or very close to the water table and the probability of groundwater impact was high. The nearest wells monitored in regional groundwater studies are over one km from the Area 3 RWMS.

Potential contaminant transport from the underground test cavities down to groundwater in the regional carbonate aquifer may be delayed by the formation of puddle glass at the bottom of the test cavities, the presence of zeolites in the rocks and soil, the hydrogeologic properties of the unsaturated zone and the volcanic tuff aquitard, the low regional groundwater gradient, and other factors. However, fractures radiating from the nuclear test could locally enhance transport. 


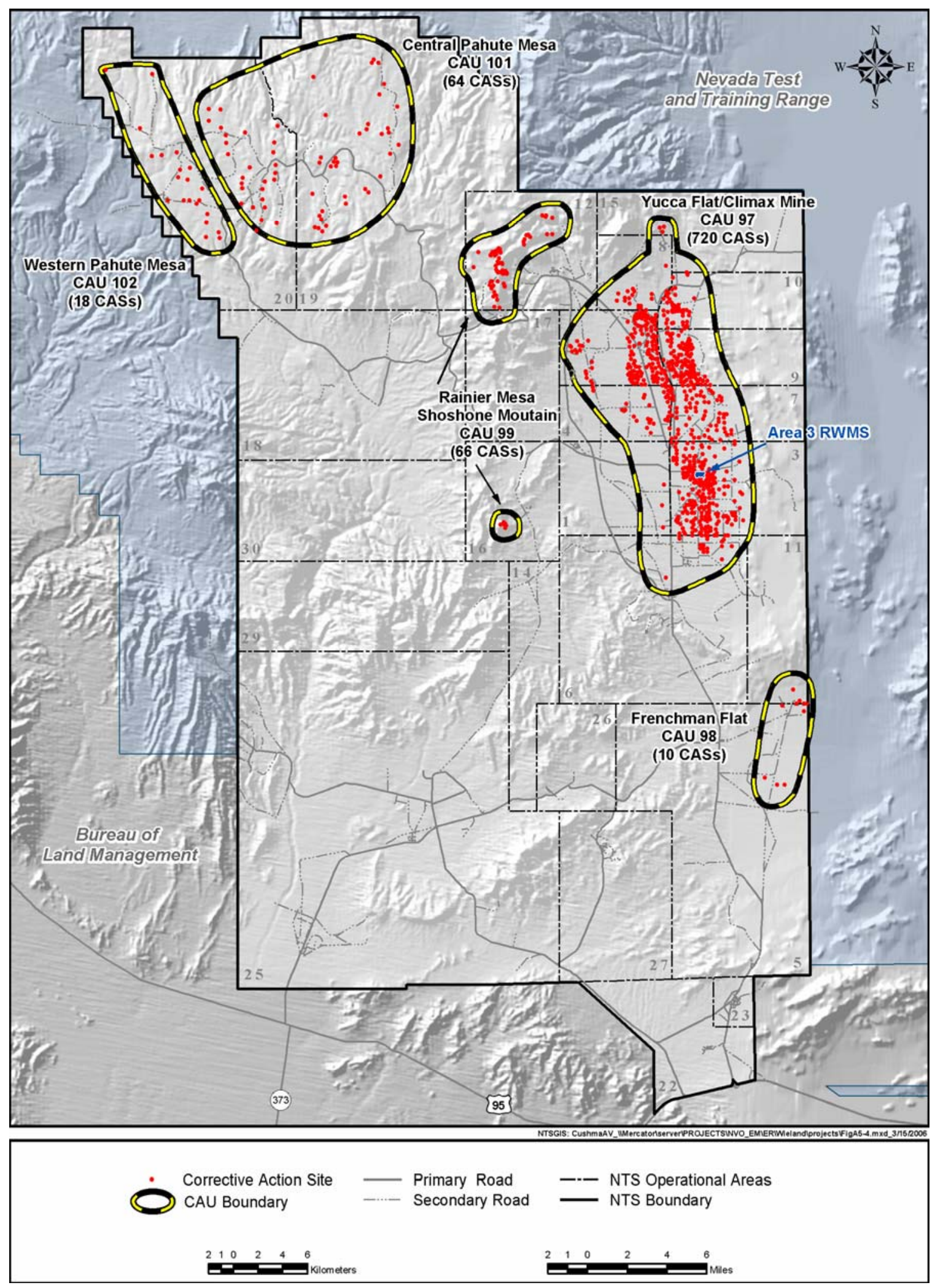

Figure 11

Corrective Action Unit 97 
Table 9

FFACO CAU 97 Corrective Action Sites within the Area 3 RWMS

\begin{tabular}{|c|c|c|c|c|c|c|}
\hline CAS & $\begin{array}{l}\text { Hole } \\
\text { Name }\end{array}$ & Detonation & Date & $\begin{array}{l}\text { Depth of } \\
\text { Burial } \\
\text { (m bgs) }\end{array}$ & $\begin{array}{c}\text { Depth to } \\
\text { Water } \\
\text { (m bgs) }\end{array}$ & $\begin{array}{l}\text { Land Surface } \\
\text { Elevation } \\
\text { (m amsl) }\end{array}$ \\
\hline 03-57-008 & U -3ah & FISHER & $12 / 03 / 61$ & 363.72 & 491.95 & $1,225.3$ \\
\hline $03-57-020$ & $U-3 a t$ & JERBOA & 03/01/63 & 301.14 & 490.58 & $1,223.93$ \\
\hline $03-57-024$ & $U-3 a x$ & PACA & 05/07/62 & 258.32 & 492.05 & $1,225.70$ \\
\hline $03-57-026$ & U -3az & $\begin{array}{l}\text { DORMOUSE } \\
\text { PRIME }\end{array}$ & $04 / 05 / 62$ & 260.91 & 490.43 & $1,224.08$ \\
\hline $03-57-033$ & $U-3 b g$ & ACUSHI & 02/08/63 & 260.91 & 492.23 & $1,225.88$ \\
\hline $03-57-034$ & $U-3 b h$ & HYRAX & $09 / 14 / 62$ & 216.71 & 490.70 & $1,224.35$ \\
\hline $03-57-037$ & $U-3 b l$ & BOBAC & $08 / 24 / 62$ & 206.05 & 491.95 & 1225.6 \\
\hline
\end{tabular}

\footnotetext{
Notes:

CAS Corrective Action Site identification number from the Federal Facility Agreement and Consent Order

$\mathrm{m}$ bgs Meters below ground surface

$\mathrm{m}$ amsl Meters above mean sea level
}

Source:

U.S. DOE Nevada Operations Office, 2000. The Corrective Action Investigation Plan for Corrective Action Unit 97: Yucca Flat/Climax Mine, Nevada Test Site, Nevada. DOE/NV--659. Las Vegas, Nevada. September 2000. Pages 45 and 46. 


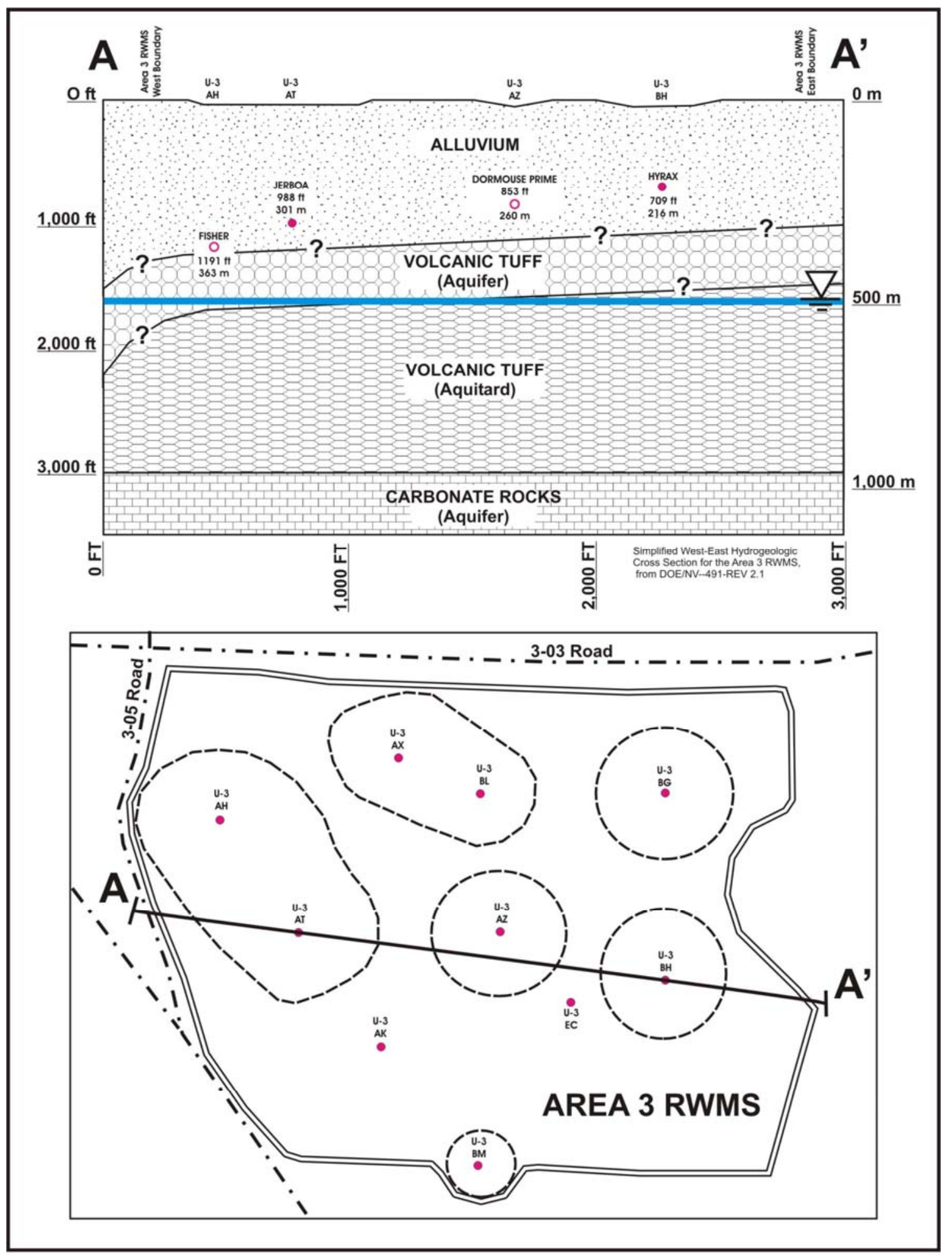

Figure 12

Simplified Cross-Section of the Area 3 RWMS 
This Page Intentionally Left Blank 


\subsection{CONCEPTUAL MODELS AND ASSESSMENTS}

Many models have been developed that have application to the characterization and assessment of the Area 3 RWMS. Some are quite specific to address a single factor, and others are more complex, addressing numerous aspects of the total disposal system and environment. Examples include:

- Hydrogeologic (BN, 2006b; Laczniak et al., 1996; BN, 1998b; Winograd and Thordarson, 1975)

- Unsaturated Flow (Shott et al., 2000; Levitt and Yucel, 2002a)

- Groundwater Recharge (Levitt and Yucel, 2002b)

- Subsidence (Crowe et al., 1999)

- Source Term (Shott et al., 2000; Yucel et al., 1996)

- Transport and Exposure (Shott et al., 2000)

- Inadvertent Human Intrusion (Black et al., 2001)

- Biological (Hooten et al., 2001; Wirth et al., 1999; Hansen and Ostler, 2003)

- General Performance Assessment (Shott et al., 2000; BN 2005a, 2004b, 2003a, 2002a)

Most scenarios for radionuclide release and transport ultimately involve some aspect of the hydrologic system. Additionally, the hydrologic environment affects monitoring, performance assessment, and closure cover design decisions. The hydrologic conceptual model for the Area 3 RWMS, and the performance assessment and composite analysis are briefly described below.

\subsection{Hydrologic Conceptual Model for the Area 3 RWMS}

BN (1998b) identified potential transport processes and presented conceptual hydrogeologic models for the crater environment prior to waste emplacement and after emplacement of the waste and landfill cover, based on the results of the characterization studies of the upper vadose zone. The conceptual model continues to be refined as more data become available. Shott et al. (2000) reviewed the characterization data and drew similar conclusions. The boundaries of some of the zones described below vary by a meter or two in the literature due to interpretation and rounding of values, but all reviewers agree on the overall interpretation of this set of data.

The BN researchers (BN, 1998b; Shott et al., 2000) concluded that the surface 1 to $3 \mathrm{~m}$ ( 3 to $10 \mathrm{ft}$ ) of alluvium is hydrologically active and climate and vegetation strongly control the movement of water. The magnitude and direction of the near-surface liquid and vapor water fluxes varies temporarily and spatially with infiltration events, changes in evaporation and transpiration rates, local soil, and plant cover conditions. The fluxes vary seasonally and often daily. Except for periods following precipitation events, the moisture content in this near-surface zone is quite low and the mean matrix potential profile in the surface soil is upward. Most bioturbation is in the surface $2 \mathrm{~m}(6 \mathrm{ft})$. Below $2 \mathrm{~m}(6 \mathrm{ft})$ to a depth of approximately $5 \mathrm{~m}(16 \mathrm{ft})$, root and animal activity diminish, but can still occur.

Below the near-surface alluvium is a region where relatively steady upward movement of water is occurring in the undisturbed alluvium. In this zone of slow upward moisture movement, 
analyses of stable isotope compositions of soil pore water confirm that evaporation is the dominant process (Tyler et al., 1996). This zone extends to a depth of about $49 \mathrm{~m}(161 \mathrm{ft})$ at the Area 3 RWMS (BN, 1988b; Shott et al., 2000).

Below this zone, water potential measurements indicate the existence of a static zone, which is approximately 49 to $119 \mathrm{~m}$ (160 to $390 \mathrm{ft}$ ) below the ground surface in Area 3 (BN, 2005c). At U-3at and U-3bl, interpretation of matric potential trends suggest that the static zone extends from $50 \mathrm{~m}(164 \mathrm{ft})$ to about $120 \mathrm{~m}$ (394 ft) (Shott et al., 2000). In this static zone, essentially no vertical liquid flow is currently occurring. Below this static zone (below approximately $120 \mathrm{~m}$ [394 ft]), the flow is quasi-steady-state and downward due to gravity. Stable isotope compositions of pore water from these depths indicate that infiltration into this zone occurred under cooler, past climatic conditions (Tyler et al., 1996). Figure 13 is a diagram of this conceptual model. The water table is thought to be within a tuff aquifer unit under the western part of the Area 3 RWMS and in a tuff confining unit under the eastern part of the RWMS, as depicted in Figure 8 (BN, 1998b).

Conceptual flow and transport models have been developed with consideration of the site conditions before waste was emplaced, while waste continues to be disposed, and after emplacement of the closure cap.

While the cap is maintained, it is assumed that the upper 1 to $3 \mathrm{~m}(3.3$ to $9.9 \mathrm{ft})$ of the cover will accommodate episodic infiltration of storm water, evaporation, and most of the bioturbation. Ants and a few shrub roots may extend below this cover to a depth of about $5 \mathrm{~m}(16 \mathrm{ft})$. Water flux in this zone is anticipated to be nearly steady and upward in the surface $5 \mathrm{~m}(16 \mathrm{ft})$. In the zone below the waste, water from infiltration events prior to waste emplacement will continue to redistribute. Because the depth to groundwater from this depth is another approximately $412 \mathrm{~m}$ $(1,353 \mathrm{ft})$ below, the moisture in this zone may never equilibrate. Hydraulic gradients will decrease with time. Water fluxes will remain very small, downward, and outward (BN, 1998b). After active institutional control ends, future subsidence from settling of the waste packages and cover may provide an increase in the potential downward flux as depressions allow storm water to pond longer and cracks transmit more water through the cover. However, modeling indicates that recharge will still not occur (Shott et al., 2000). Layering and slight differences in moisture content may significantly reduce downward flow.

Results of the extensive research, field studies, modeling efforts, and monitoring data summarized in the Area 3 PA (Shott et al., 2000; Levitt and Yucel, 2000a, 2000b; Levitt et al., 1999, 1998) suggest that the potential for recharge is negligible. Recent lysimeter data also suggest that the potential for significant water movement into the waste is low (see Section 12.4.2).

Tracer and tritium data from the characterization of the U-3bh crater site, which was an open crater for over three decades prior to development as a waste disposal cell, shows evidence of infiltration of water to a depth of $69 \mathrm{~m}(226 \mathrm{ft})$. Researchers concluded that data from boring U-3bh-C2 shows three distinct pulses of tritium transport downward and concluded that there is a 


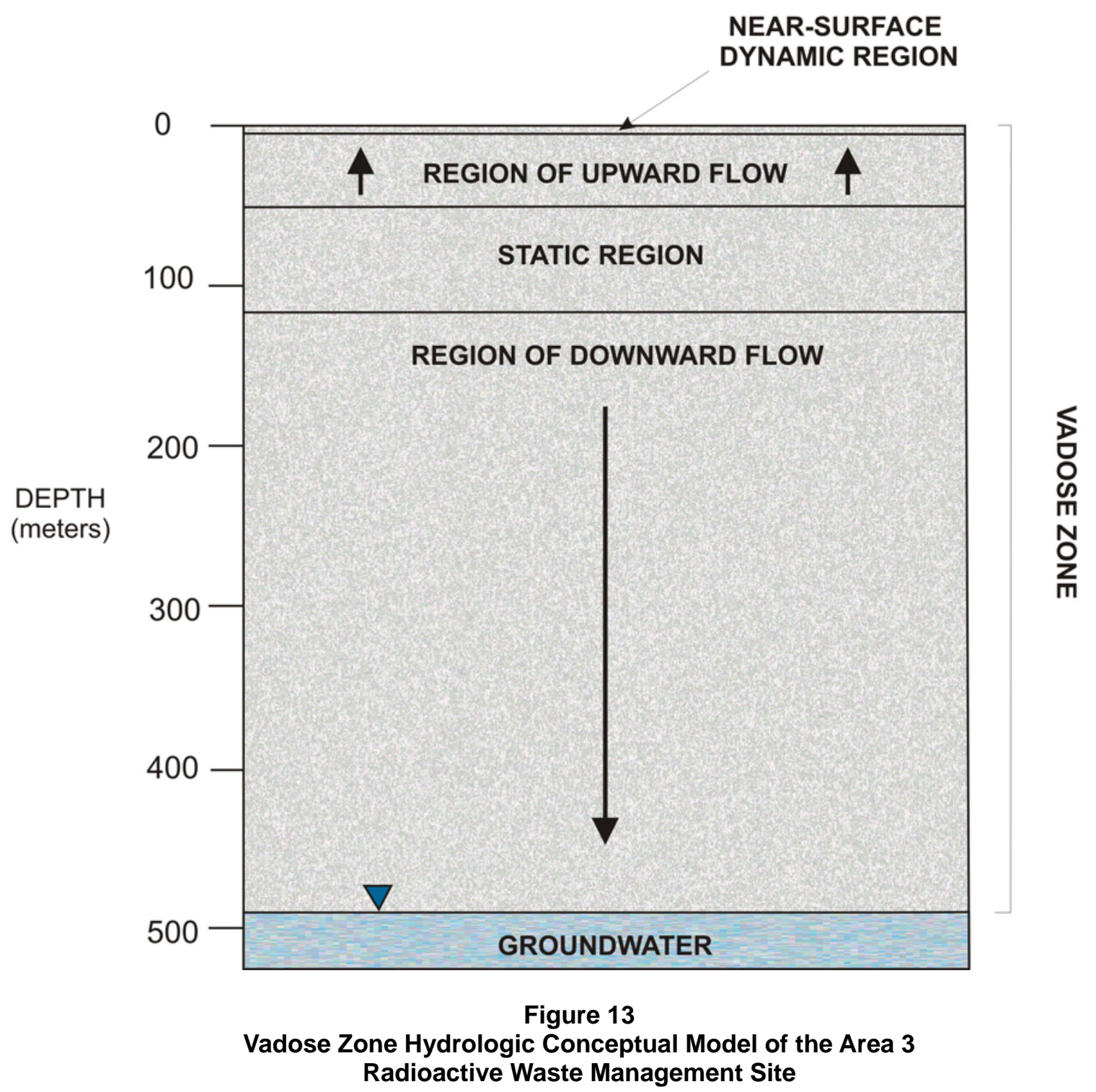

zone varying 10 to $20 \mathrm{~m}$ (33 to $66 \mathrm{ft}$ ) below the crater floor that appears to have had a high frequency of infiltration events represented by alternating zones of depletion and enrichment of stable isotopes with depth. Tritium levels declined as the soil got drier. The researchers identified an interval of about $40 \mathrm{~m}(131 \mathrm{ft})$ characterized by higher water contents that is slowly redistributing (Shott et al., 2000). There are no indications of an increased water content below $70 \mathrm{~m}(231 \mathrm{ft})$ depth (Shott et al., 2000). Modeling suggests that although past infiltration events raised water content in a zone below the crater, little movement is likely to occur after closure while the cover is maintained during the period of institutional control (Shott et al., 2000).

After routine maintenance of the cover ends and subsidence creates sinks and cracks in the cover allowing more ponding and potential infiltration, eventually vertical fluxes will increase. However, even if moisture moves past the static zone, movement to the aquifer would be extremely slow due to the low water content of the alluvium. Layering of units with varying hydraulic properties also slows potential vertical flow. 
Modeling of travel times at the Area 5 RWMS are indicative of what travel rates may be like at the Area 3 RWMS. An unsaturated flow model was used to predict estimated travel times for the unretarded movement of water from the bottom of the static zone to the capillary fringe zone of the groundwater table in the uppermost aquifer at the Area 5 RWMS. The modelers concluded that there is a 95 percent probability that the travel time (under the assumption that horizontal layer thickness is uniformly distributed between 0.6 and $2.6 \mathrm{~m} \mathrm{[1.9}$ and $8.5 \mathrm{ft}]$ ) is between 31,795 to 101,944 years (Shott et al., 1998). The alluvium of Yucca Flat is fairly similar to the alluvium of Frenchman Flat, but the vadose zone at the Area 3 RWMS is significantly thicker than at the Area 5 RWMS. Travel times to groundwater at the Area 3 RWMS are also likely to be very long.

A vadose zone transport model for the Area 3 RWMS was developed based on the hydrologic conceptual model and characterization data. The transport model was used to estimate transport times to groundwater to evaluate if groundwater was a viable pathway for performance assessment and composite analysis. Shott et al. (2000) summarizes the process and results. It is assumed that subsidence occurs at the end of the institutional control period. To bound the fastest rates, the model was run under a set of conservative assumptions reflecting relatively extreme conditions. These assumptions included:

- Maximum subsidence occurs at the disposal cell

- Runoff from a 1,000-year storm event ponds in the subsided cell and the net infiltration from this ponded storm water leads to recharge to the groundwater

- The resultant recharge rate is a steady-state flux rate used to estimated advective transport velocity

- The soil column has a high moisture content throughout, and the high moisture content persists, facilitating flow

- Low values are assigned to distribution coefficient of radionuclides, assuming the soil column is sand

Under these favorable conditions for flow, the time from facility closure to the time when infiltrated water reaches the water table would be 1,200 years. Estimates of the time to reach the water table for each of the radionuclides that may leach from U-3ah/at, considering retardation and soil moisture, were all greater than the post-closure 1,000-year regulatory compliance period under these conservative assumptions. Tritium would reach the groundwater table with the percolating water in 1,200 years, technetium in 2,160 years, and all other radionuclides in excess of 10,000 years (Shott et al., 2000). These modeling results indicate that the groundwater pathway is not a viable pathway for exposure (Shott et al., 2000). Under more realistic conditions, travel times would be even greater than these estimates. The prospect of recharge in the vicinity of the Area 3 RWMS is very low.

Given that the lysimeter data indicate that very little precipitation will percolate through the landfill cover to the waste, even under climate conditions three times as wet as it was in the wet year of 2004, and the modeled slow travel rates at the similar Area 5 RWMS, no recharge is occurring in the vicinity of the Area 3 RWMS under current conditions. 
Even if sufficient water could get into the waste to create a leachate contaminated with radionuclides, and if recharge were to occur, significant decay would occur over the perhaps many thousands of years required to reach the groundwater. Groundwater is an unlikely pathway of contaminant transport at the Area 3 RWMS.

The conceptual model for radionuclide transport and release at the Area 3 RWMS focuses on the upward transport of soluble radionuclides by liquid advection and diffusion with retardation, the movement of soluble and particulate radionuclides by plants and burrowing animals, and the movement of gaseous radionuclides by diffusion and with the liquid phase. The PA model incorporates the hydrological and contaminant transport conceptual models to evaluate potential exposures of people to contaminants in the future under various land use and inadvertent intrusion scenarios.

\subsection{Performance Assessment and Composite Analysis}

\subsubsection{Overview}

A PA is a systematic analysis of potential risks to the public and environment from a LLW management site, and includes a comparison of those risks to the established performance objectives. The applicable radiological performance objectives for long-term protection of the public and the environment from waste operations at the Area 3 RWMS were initially defined in DOE Order 5820.2A "Radioactive Waste Management" (DOE, 1988), which was superseded in 1999 by DOE Order 435.1, and modified in 2001. The related manual, DOE M 435.1-1 (DOE, 2001a), also defines the performance objectives. Regulated LLW under DOE Order 435.1 is limited to waste disposed from September 26, 1988, to the anticipated closure date. Thus, the PA for the Area 3 RWMS is based on disposal inventory since September 1988, and addresses disposal at U-3ah/at and U-3bh. Waste disposal at the U-3ax/bl disposal cell predates the regulatory period.

The CAs are planning tools used by the NNSA/NSO to ensure that the combined effect of all sources of residual radioactive material at a DOE facility will meet requirements for long-term protection of the public and environment. The CA for the Area 3 RWMS takes into account the cumulative risks all potential sources including the waste deposited before September 26, 1988 (at U-3ax/bl), and residual contamination from past atmospheric and underground nuclear tests.

The PA and CA for the Area 3 RWMSs were presented in a single document prepared by BN for the NNSA/NSO (Shott, et al., 1997). DOE Headquarters (HQ) reviewed the assessments taking into consideration recommendations of the Low-Level Waste Disposal Facility Federal Review Group. DOE/HQ issued a Disposal Authorization Statement (DAS) for the Area 3 RWMS on October 20, 1999 (DOE, 1999), and identified several issues to be resolved through a revision of the PA and CA. Revision 2.1 was issued in October 2000 (Shott et al., 2000). NNSA/NSO submitted the revised PA and CA in 2001 to DOE/HQ, and further documentation in a letter report in January 2002. In August 2002, DOE/HQ indicated that all the issues identified in the DAS had been resolved except for topics to be addressed through the maintenance program.

The Maintenance Plan for the Performance Assessments and Composite Analyses for the Area 3 and Area 5 Radioactive Waste Management Sites at the Nevada Test Site (BN, 2002) describes the process to update the PA and CA throughout the operational life of each RWMS. The goal is to reduce uncertainty in the assumptions and input parameters and provide an on-going means to 
accommodate change. The maintenance program includes continued development of assessment and decision tools, reviews, revisions to the assessments as needed, annual summary reports to DOE/HQ, special studies, support to the NTS Radioactive Waste Acceptance Program, revision of the maintenance plan itself as needed, and annual scheduling of task supervision to support execution of the maintenance program. The annual summary reports provide timely periodic review and updates. Annual summary reports were prepared by BN for the NNSA/NSO to document the reviews of the PA and CA for 2001 (BN, 2002a), 2002 (2003a), 2003 (2004b), 2004 (2005a), and 2005 (BN, 2006a). Revisions to the PA and CA are made on an as-needed basis. The DAS (DOE, 1999b) requires a revision of the Area 3 RWMS CA to incorporate results of the Yucca Flat CAU 97 Corrective Action Decision Document (CADD), scheduled for completion in 2020. During the post-closure active management period, PA and CA revisions may continue to be made if environmental monitoring program results indicate that further analyses are warranted.

\subsubsection{General Assumptions and Performance Objectives}

The Area 3 RWMS PA and CA assume that institutional control of Yucca Flat can be maintained for 250 years and that there will be no inadvertent intrusions of the Area 3 RWMS site until active institutional control ends. The 250 -year estimate of institutional control was developed by a panel of subject matter experts. Active institutional control is assumed to be effective in deterring intrusion for at least 100 years after closure in accordance with DOE M 435.1-1 [DOE, 2001a, Chapter IV, Low-Level Waste Requirements, Section P.(2)(h)].

The PA compliance boundary is conservatively assumed to be $100 \mathrm{~m}(328 \mathrm{ft})$ from the edge of the Area 3 RWMS. In reality, future residential use of Yucca Flat is very unlikely because it is extensively cratered from 659 historic underground nuclear experiments. Future agricultural use is also not very likely because of the depth to groundwater and low soil fertility. The compliance period for maintaining performance is 1,000 years based on DOE guidance established in 1996 (DOE, 1996b) and DOE Order 435.1 (DOE, 2001c). The PA and CA models project that compliance will be maintained. For a better understanding of long-term performance in the PA, doses to members of the public and inadvertent human intruders are estimated for longer time periods, but this is not a regulatory requirement for operation or closure.

DOE requires that all releases of radioactive materials be maintained ALARA. The

DOE-defined performance objectives for the Area 3 RWMS PA for a member of the public living just beyond the 100-m (328-ft) site boundary include radiation doses through all pathways, radiation (excluding radon) through air pathways, and radon flux density. The PA evaluates the potential exposures to people in the future for various land-use scenarios, including a member of

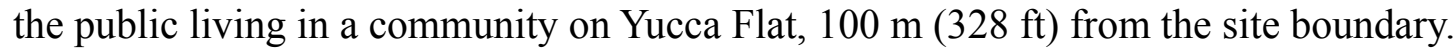

Land-use plans and use restrictions are assumed to prohibit construction and well drilling within the site boundaries in perpetuity, but in case administrative restrictions are ineffective, and any monuments and signs marking the landfill disappear, the PA also models inadvertent intrusions in the landfill area resulting in exhumed contaminants and residency in the resulting contaminated area. The intrusion scenarios include excavation to construct a house with a basement and drilling to install a well.

The PA performance objectives for doses to an inadvertent human intruder assumes the intruder resides within the Area 3 RWMS site boundary after institutional control ends, and exhumes 
buried waste through building a house with a basement and drilling a well through a landfill cell. The inadvertent human intruder performance objectives address groundwater resource protection, acute exposures, and chronic exposures.

For the Area 3 RWMS, the PA and CA (Shott et al., 2000) assume that the closure cover will consist of native alluvium. It is assumed that the cap will erode and subside, resulting in a reduction of cap thickness to $3 \mathrm{~m}(10 \mathrm{ft})$ thickness and development of cracks that will provide a preferential pathway for release of volatile radionuclides from the waste by diffusion. Infiltration through the cap is assumed to increase but, due to the very arid climate, storm water runoff from most rain events will continue to evapotranspire back to the atmosphere. Only runoff from large, infrequent events would penetrate the cap. Conservative modeling of radionuclide transport time suggests that any contamination leached from the waste and carried with the percolating storm water runoff is unlikely to reach the uppermost aquifer within 1,000 years. There is effectively no groundwater pathway for exposure of a member of the public to contaminants from the landfill during the 1,000-year compliance period. Plant uptake of radionuclides, burrowing mammals, and upward advection of solutes in pore water are considered in the exposure scenarios. The PA/CA (Shott et al., 2000) describes the scenarios in detail and summarizes the component models. The PA and CA draw from many of the characterization models cited at the beginning of Section 6.0.

The purpose of the CA is to determine if continuing operation of the Area 3 RWMS poses an acceptable risk to the public, considering potential dose from the total waste inventory (including pre-1988 waste disposed at U-3ax/bl) and from all other interacting sources of radioactive material in the vicinity. It is a very conservative analysis of potential exposure and can be considered a worst case.

A member of the public residing in the vicinity of the Area 3 RWMS may be exposed to residual surface contamination from past nuclear testing in Yucca Flat and Plutonium Valley and to contamination in groundwater from nuclear testing.

Section 5.0 discussed some of the other contamination sources in the vicinity of the site. The CADD has not been developed yet for CAU 97, but it is anticipated that remediation of the groundwater within CAU 97 will not be economically feasible and that an administrative restriction will be implemented to manage the groundwater contamination at the UGTA. The CA assumes that the Area 3 RWMS will be within this restricted containment area.

The model assumes there will be some resuspension and atmospheric dispersion of soil contamination from Yucca Flat and Plutonium Valley. The member of public is assumed to reside within a ground zero soil contamination site created by atmospheric tests.

\subsubsection{General Results}

Performance objectives and results of PA modeling are summarized in Table 10. Based on the PA, the Area 3 RWMS meets regulatory performance objectives by a wide margin.

The dose from all interacting sources to a member of the public is calculated for the Area 3 RWMSs to be on average $2 \mathrm{mrem} / \mathrm{yr}$ and a maximum of $8 \mathrm{mrem} / \mathrm{yr}$ (Shott et al., 2000). The CA performance objective is $100 \mathrm{mrem} / \mathrm{yr}$ to a member of the public with a dose constraint of $30 \mathrm{mrem} / \mathrm{yr}(\mathrm{BN}, 2005 \mathrm{c})$. 
Table 10

Performance Objectives and Results of the

Area 3 RWMS Performance Assessment

\begin{tabular}{|c|c|}
\hline \multicolumn{2}{|c|}{ MEMBER OF PUBLIC } \\
\hline Performance Objective & $\begin{array}{c}\text { Area } 3 \text { RWMS (Base Case) } \\
\text { 1,000-yr analysis; maximum values unless } \\
\text { specified otherwise }\end{array}$ \\
\hline $25 \mathrm{mrem} / \mathrm{yr}$, all paths & $\begin{array}{l}0.0009 \mathrm{mrem} / \mathrm{yr} ; \\
0.00004 \mathrm{mrem} / \mathrm{yr} \text { (mean) }\end{array}$ \\
\hline $\begin{array}{l}10 \mathrm{mrem} / \mathrm{yr} \text {, airborne emissions excluding } \\
\text { radon }\end{array}$ & $\begin{array}{l}0.0004 \mathrm{mrem} / \mathrm{yr} ; \\
0.00003 \mathrm{mrem} / \mathrm{yr} \text { (mean) }\end{array}$ \\
\hline Average annual ${ }^{222} \mathrm{Ra}$ flux $<20 \mathrm{pCi} / \mathrm{m}^{2} / \mathrm{s}$ & $\begin{array}{l}0.1 \mathrm{pCi} / \mathrm{m}^{2} / \mathrm{s} \\
0.02 \mathrm{pCi} / \mathrm{m}^{2} / \mathrm{s} \text { (mean) }\end{array}$ \\
\hline Protect groundwater resources & No Release (mean) \\
\hline $\begin{array}{l}-{ }^{226} \mathrm{Ra}+{ }^{228} \mathrm{Ra} \\
\quad<5 \mathrm{pCi} / \mathrm{L}\end{array}$ & Not Applicable $^{a}$ \\
\hline $\begin{array}{r}\text { - Gross alpha } \\
<15 \mathrm{pCi} / \mathrm{L}\end{array}$ & Not Applicable $^{a}$ \\
\hline $\begin{array}{l}\text { - Man-made beta-gamma emitters } \\
<4 \mathrm{mrem} / \mathrm{yr}\end{array}$ & Not Applicable $^{a}$ \\
\hline \multicolumn{2}{|c|}{ INADVERTENT HUMAN INTRUDER } \\
\hline 500 mrem Acute & $<0.04$ mrem (mean) \\
\hline 100 mrem/yr Chronic & $0.04 \mathrm{mrem} / \mathrm{yr}$ (mean) \\
\hline
\end{tabular}

Modeling results indicate that potential doses to a member of the public at the relevant points of compliance for each pathway and scenario met the performance objectives by wide margins. The Area 3 RWMS also achieves the intruder protection, radon flux density, and groundwater protection objectives by wide margins.

The approved Area 3 RWMS PA model has been integrated into a probabilistic, dynamic modeling platform using the Golder Associates GoldSim computer code. The Annual Summary Reports (e.g., BN, 2006a) document the progress in developing the GoldSim model. The biotic transport model has been refined with the results of new, more detailed studies of plant rooting and animal burrowing characteristics. Closure inventory estimates have been updated. Monitoring results continue to support PA assumptions and models.

The CA for the Area 3 RWMS indicates the combined TEDE for the Area 3 RWMS and surrounding contaminated soil sites will be far below the $100 \mathrm{mrem} / \mathrm{yr}$ chronic exposure dose limit throughout the 1,000-year compliance period. Greater than 80 percent of the dose is attributable to past nuclear testing and not the Area 3 RWMS waste (Shott et al., 2000). Doses for inadvertent intruders at the different waste cells varied slightly but were all low. 
The nature and distribution of plants and animals and their ecological interactions are of interest both as agents of contaminant transport and as potential receivers of contaminants. The type, maturity, and density of vegetation affect runoff characteristics, infiltration characteristics, the temperature of surface soils, wind speeds at ground surface, and consequently the potential for evapotranspiration, soil erosion, and infiltration of rainwater. Vegetation is one factor, among many, affecting the maintenance of landfill covers and potential movement of water within the first few meters of soil and alluvium. Rooting depth is closely tied to soil moisture availability. The potential for plants to enhance vertical movement of water downward towards buried waste is offset by their use of water to live and grow. Decomposition of roots provides channels for water and vapor and may enhance infiltration and percolation through the rooting depth, but plants remove water from the soil, store it in biomass, and transpire moisture back to the atmosphere. Plants can also directly take up radionuclides from the soil, concentrate them in their biomass, and release the radionuclides to the atmosphere via transpiration or to the surface when they decompose.

Plants are often an integral part of a landfill soil closure cover system, whether the plants are intentionally selected and planted in ways to maximize the benefits of the vegetative cover, or the cover is designed to allow the gradual natural population of the area by surrounding species. Plant evapotranspiration minimizes potential water transport through the cover and the plant canopy, and roots help control erosion of the surface by wind and rain. The U-3ax/bl final cover was revegetated with native species.

Fauna has a potential role in transport of near-surface radioactive contaminants through burrowing and the food chain. The depth of burrowing is tied closely to soil conditions and plant rooting depths. Burrowing wildlife affect the permeability of near-surface soil and alluvium.

There have been many characterization studies of the NTS vegetation and wildlife since the 1960s. Recent studies most relevant to the characterization of current communities, evaluation of rooting and burrowing characteristics, and the potential for radioactive contaminants to affect the biota as well as the potential for biota to assist contaminant transport include:

- W. K. Ostler, D. J. Hansen, D. C. Anderson, and D. B. Hall (2000), Classification of Vegetation at the Nevada Test Site

- C. A. Wills and W. K. Ostler (2001), Ecology of the Nevada Test Site: An Annotated Bibliography

- D. J. Hansen and W. K. Ostler (2003), Rooting Characteristics of Vegetation Near Areas 3 and 5 Radioactive Waste Management Sites at the Nevada Test Site

- M. M. Hooten, J. T. Markwiese, T. G. Myles, P. Black, and R. Ryti (2001), A Literature Review of Biotic Components, Processes, and Characteristics Central to biotic Transport Modeling of Soils at the Nevada Test Site

Neptune and Company, Inc., investigations included characterization studies of ant and termite communities in the vicinity of the RWMSs, and an evaluation of the potential for ants and termites to transport contaminants. DOE funded these investigations to help determine rates of 
bioturbation and input parameters for the Area 3 RWMS GoldSim probabilistic transport model. Preliminary results have already been incorporated in the model. Neptune and Company, Inc., is expected to publish a report regarding their recent studies in FY 2006 (personal communication, Hooten to Wieland, 2006).

\subsection{Vegetation}

The Area 3 RWMS is in a transitional area between the Mojave and Great Basin Deserts with high species diversity in mixed shrub communities. In 2001 and 2002, BN biologists conducted field surveys to characterize plant community composition and biomass. Hansen and Ostler (2003) evaluated three study plots near the Area 3 RWMS: Site 3 in a white burrobush-green rabbitbrush plant community $1.9 \mathrm{~km}(1.2 \mathrm{mi})$ northeast, Site 4 in a mixed shrub community $1.5 \mathrm{~km}(0.9 \mathrm{mi})$ northwest, and Site 5 in an Anderson wolfberry-white burrobush plant community $1.9 \mathrm{~km}(1.2 \mathrm{mi})$ northwest of the Area $3 \mathrm{RWMS}$. These study sites were selected to represent the major vegetative associations of the area, relatively undisturbed conditions, a range of biomass values, and because they had similar soils and landforms as at the Area 3 RWMS. The biologists also evaluated sites in big sage brush communities in Area 17 and 18 thought to be representative of plant communities in relatively wetter and cooler conditions. These data are relevant because the climate may become wetter and cooler during the 1,000-year compliance period after closure of the Area 3 RWMS.

The natural vegetation in the vicinity of the Area 3 RWMS is sparse. Total percent shrub cover at three study plots varied from 3.4 percent to 36.9 percent (Hansen and Ostler, 2003). The maximum depth of roots for the species with the highest relative densities and the highest relative abundances were less than $60 \mathrm{~cm}(2 \mathrm{ft})$. Creosote bush had the deepest roots of the shrub species; however, creosote was identified at only one of the three plots with a relative density of 3 percent and abundance of 2 percent. The maximum depth of creosote roots was $180.0 \mathrm{~cm}$ $(5.9 \mathrm{ft})$ (Hansen and Ostler, 2003). This suggests that roots of native shrubs likely to revegetate the covers of the Area 3 RWMS are unlikely to penetrate the covers. Biomass production is correlated with precipitation.

Other studies also indicate roots of shrubland species that grow at the NTS are mostly confined within the top $5 \mathrm{~m}(16.4 \mathrm{ft}$ ) of soil (see Foxx et al. [1984a and 1984b], and Tierney and Foxx [1987]). The roots of Mojave Desert and Transitional Desert plants at the NTS are concentrated near the surface to maximize capture of infiltration (Winkel et al., 1995; Hansen and Ostler, 2003). Availability of oxygen has been found to limit creosote root depths, perhaps even more than the availability of soil moisture (personal communication, Hansen to Wieland).

Wallace and Romney (1972) described root systems of plants excavated from a wash in Rock Valley on the NTS, at a study site selected because of an absence of caliche hardpan, which can restrict rooting depths. Creosote bush roots reached $168 \mathrm{~cm}$ (66 in.) below surface, but over 82 percent of the creosote roots were in the top $30 \mathrm{~cm}$ (12 in.) of soil. About 85 percent of the

Schockley goldenhead roots were in the top $20 \mathrm{~cm}$ (8 in.) of soil, and none reached below a $40 \mathrm{~cm}$ (16 in.) depth. Desertthorn winterfat roots at the Rock Valley site reached $64 \mathrm{~cm}$ (25 in.) below surface.

Wallace et al. (1980) also excavated root systems of several Mojave Desert species at the NTS. The roots were distributed in the top $51 \mathrm{~cm}$ (20 in.), except for fourwing saltbush and shadscale; 
less than 2 percent of the roots of these two species were found below $51 \mathrm{~cm}(20 \mathrm{in}$.). Beatley (1969) noted that winter annuals root in the top $20 \mathrm{~cm}$ (8 in.) of soil. Wirth et al. (1999) also compiled rooting depths of various plant species found on the NTS.

If current conditions continue, slight changes in vegetation will continue due to introduction of exotic species. Exotic annual species, especially grasses with shallow rooting depths, gradually have been displacing annual forbs, native grasses, and some shrubs. The increased litter may provide more fuel for wildfires that burn shrubs (Hansen and Ostler, 2003).

Several studies have estimated the time for disturbed areas to naturally revegetate and the characteristics of communities likely to become established. These studies give an indication of how long it may take a native alluvium landfill cover to revegetate naturally. Sutter et al. (1993) suggest that revegetation of the Area 5 RWMS waste covers, which are similar to those planned for the Area 3 RWMS, whether managed in the beginning or left to occur naturally, likely will progress from bare soil to desert shrubland in less than 50 years. However, many studies suggest that recovery of vegetative cover may take much more time. Webb et al. (2003) looked at changes in plots originally established at the NTS by Dr. Janice Beatley in 1963. The plots had been disturbed by fires and other factors, and were ecologically monitored from 1963 to 1975 and 2000 to 2003. Webb concluded that species compositions of disturbed plots compared to undisturbed plots at the NTS are very different, and that although some vegetative cover will reestablish in 50 years, a millennium may be required for recovery of the native species composition.

Similarly, Ostler et al. (2002) studied recovery of plants at sites disturbed by military activities in the Mojave desert and projected that recovery may require hundreds of years to achieve predisturbance levels of vegetation cover in arid lands.

Angerer et al. (1994) studied plant succession on disturbed sites at Yucca Mountain, Nevada. The study area included the west edge of the NTS. Extrapolation of observations indicated that approximately 845 years would be required for the amount of cover on disturbances to reach that of undisturbed areas. Estimates of individual recovery rates for ten dominant species ranged from 31 years to 1,100 years. The time to develop a plant community very similar to the original undisturbed community would be much greater. Angerer et al. (1994) cites several other studies of plant succession in disturbed areas in the Mojave Desert with similar rates.

Hansen and Ostler (2003) noted that a big sagebrush community could eventually result if the climate became sufficiently cooler and wetter at the Areas 3 and 5 RWMSs; however, piñon and juniper trees are unlikely to become established at the RWMS sites, which have deep soils and are in valley bottoms vulnerable to drought and fire. Therefore, even under wetter, cooler conditions, rooting depths of native plant communities are likely to remain shallow. Additional discussion on NTS vegetation can be found in Wills and Ostler (2001) and in Hansen and Ostler (2003). Planting and irrigation may be used to speed establishment of appropriate vegetation on the landfill covers. Vegetation planting at U-3ax/b1 has been successful (personal communication, Richardson to Wieland, 2006). 


\subsection{Wildlife}

Ants and termites are the most numerous burrowing insects on the NTS (O'Farrell and Emery, 1976). Vertebrates are less numerous and diverse. They include game and fossorial (burrowing) species. Both small and large burrowing mammals are present in the areas of the RWMSs. Rodents are the most common of the mammalian species on the NTS (Allred et al., 1963). For summaries characterizing NTS fauna, see Shott et al. (2000), Winkel et al. (1995), and Thompson (1993).

The annual NTS environmental reports (e.g., BN, 2005h) summarize the monitoring, compliance, survey, habitat restoration, and other activities designed to minimize impacts to wildlife. Biologists have identified 42 animal species on or near the NTS that are protected or managed under federal or state regulations or are considered sensitive species by natural resource experts. Ecological monitoring and regulatory compliance is performed in accordance with the Bechtel Nevada Ecological Monitoring and Compliance Program. Many studies have been conducted to characterize the occurrence, distribution, and susceptibility of plants and animals to potential natural and man-made threats at the NTS. Natural resource goals include protection and conservation of sensitive species and mitigation of potential impacts to those species from NTS activities.

Shott et al. (2000) reviewed many faunal studies and summarized data on population densities and burrowing habits. Rodents are the most abundant burrowing mammals at the NTS (Allred et al., 1963). Typical burrowing depths for the species of mice, rats, and gophers commonly observed at the NTS are less than $1 \mathrm{~m}$ (39 in.). Kit fox burrows have been found as deep as $3 \mathrm{~m}$ $(10 \mathrm{ft})$ at the NTS, but kit foxes have a low population density, so the potential for disturbance of waste by a kit fox burrowing through a landfill cover is low. Shott et al. (2000) concluded that direct intrusion into buried waste by vertebrates is unlikely, but shallow vertebrate burrowing could affect the Area 3 RWMS site performance by mixing surface soils and by altering hydraulic properties and the stability of the landfill cap.

Because invertebrates (especially insects) are more numerous and may burrow to deeper depths, invertebrate burrowing may have a greater potential for release of waste than vertebrate burrowing. However, data on invertebrate populations at the NTS are sparse.

Termites have been known to excavate burrows as deep as $6 \mathrm{~m}(20 \mathrm{ft})$ in the arid southwest; however, because plant roots are a primary food source for termites, their burrowing depths are also closely related to rooting depth. Shrubs with shallow rooting depths predominate around the Area 3 RWMS (see previous section). Some ant species may burrow deeper than termites, yet the overall volume of material likely to be moved to the surface by these insects is small. 


\subsection{CLIMATE AND METEOROLOGY}

The NTS is located between the northern boundary of the Mojave Desert and the southern limits of the Great Basin Desert. The climate of this transitional desert "can be considered typical of either the Dry Mid-Latitude or Dry Subtropical climate zones” (Shott et al., 2000). The climate is arid and characterized by low precipitation, a large diurnal temperature range, a large evaporation rate, and moderate winds. Detailed discussion of climatology and meteorology specific to the Area 3 RWMS are presented in the PA/CA (Shott et al., 2000) and the annual WMMRs (e.g., BN, 2005d). Meteorological data are important because they are used for calculation of PET, a measure of the exchange of water and heat between the earth's surface and the atmosphere, and an important component of the water balance calculation used to evaluate the potential for precipitation to infiltrate and percolate to the buried waste. The monitoring program fulfills basic regulatory requirements for meteorological monitoring per DOE Order 450.1 (DOE, 2003a).

The Air Resources Laboratory, Special Operations and Research Division (ARL/SORD) operates a network of Meteorological Data Acquisition (MEDA) stations at the NTS, including MEDA Station 17, also known as BJY, located about $3.0 \mathrm{~km}$ (1.9 mi) northwest of Area 3 RWMS in Area 1. The BJY station has been used since February 1960 and provides a long-term record of meteorological conditions in the Yucca Flat basin. Data have also been collected for at least 25 years at MEDA Station 03 in north-central Area 3.

In 1995, the Area 3 RWMS meteorological station was installed $30 \mathrm{~m}$ (100 ft) northwest of the boundary of the RWMS to provide site-specific data. The Area 3 RWMS meteorological station is equipped to collect air temperature, relative humidity, and wind speed at heights of $3 \mathrm{~m} \mathrm{(10} \mathrm{ft)}$

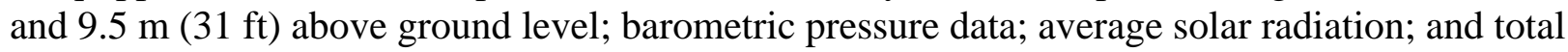
precipitation. The results at the on-site station generally have been very similar to the results at BJY. Figure 5 in Section 4.0, Monitoring Programs, shows the location of the meteorological station and other environmental monitoring stations within the Area 3 RWMS.

\subsection{Precipitation}

Most precipitation in the transitional desert occurs in winter and summer. Winter precipitation is generally associated with transitory low-pressure systems originating from the west and occurring as uniform storms over large areas. Summer precipitation is generally associated with convective storms originating from the south or southwest and occurring as intense local events.

The average annual precipitation recorded at the BJY station for 1961 through 2004 was 163.8 millimeters (mm) (6.45 in.) (ARL/SORD, 2006). The average annual precipitation for 1996 to 2004 at the Area 3 RWMS meteorological station was of similar magnitude, $162 \mathrm{~mm}$ (6.38 in.) (BN, 2005d).

In 2004, net annual rainfall at the Area 3 RWMS was 263 mm (10.35 in.), well above average (BN, 2005d). This precipitation was spread out over the year as many small rainfall events and the potential for significant runoff was low. Precipitation was measurable on over 40 days in 2004. The annual maximum daily rainfall was 26 mm (1.02 in.) on October 20, 2004 (BN, 2005d). This wetter-than-normal period provided an opportunity to evaluate landfill cover performance (see Section 12.4, Water Balance Monitoring and Cover Performance). 


\subsection{Temperature}

Average annual maximum temperature for the MEDA Station 03 in Area 3 for the period 1983 to 2001 was 22.5 degrees Celsius $\left(22.5^{\circ} \mathrm{C}\right)\left(72.5\right.$ degrees Fahrenheit $\left.\left[{ }^{\circ} \mathrm{F}\right]\right)$. The average annual minimum was $4.2^{\circ} \mathrm{C}\left(39.6^{\circ} \mathrm{F}\right)$, and the average annual temperature was $13.4^{\circ} \mathrm{C}\left(56.1^{\circ} \mathrm{F}\right)$. The extreme recorded high for the same time period was $43.3^{\circ} \mathrm{C}\left(110^{\circ} \mathrm{F}\right)$ in July 1998 and the extreme low was $-21.7^{\circ} \mathrm{C}\left(-7^{\circ} \mathrm{F}\right)$ recorded in December 1990 . The average data for the BJY meteorological station located in Area 1, northwest of the Area 3 RWMS, were very similar.

Temperature varies significantly over the year. For example, in 2004, the minimum recorded air temperature at $3 \mathrm{~m}(10 \mathrm{ft})$ above ground surface at the Area 3 RWMS meteorological station was $-13.3^{\circ} \mathrm{C}\left(8.1^{\circ} \mathrm{F}\right)$ and the maximum recorded temperature was $38.9^{\circ} \mathrm{C}\left(100.4^{\circ} \mathrm{F}[\mathrm{sic}]\right)(\mathrm{BN}$, 2005d).

\subsection{Relative Humidity}

Humidity levels affect evaporation rates. The relative humidity near the Area 3 RWMS is fairly low year round. Average relative humidity for the 1983 to 2001 period of record at the Area 3 MEDA station was 54 percent at 4 a.m. and 24 percent at 4 p.m. Results for the BJY MEDA station in Area 1 were similar: for the 1981 to 2001 period of record, relative humidity averaged 53 percent at 4 a.m. and 26 percent at 4 p.m. (ARL/SORD, 2002). See http://www.sord.nv.doe.gov/products/meda_climate_summaries.

\subsection{Potential Evapotranspiration}

Evapotranspiration reduces potential storm water infiltration, which reduces potential for water to percolate through the landfill covers and into the waste deposits. PET is usually many times higher than precipitation at the NTS. Even in 2004, a wet year when precipitation was well above average, annual PET was about six times greater than annual precipitation at the Area 3 RWMS. In 2004, the total calculated PET at the Area 3 RWMS was $159.74 \mathrm{~cm}$ (63 in.), using a modified version of the Doorenbos and Pruitt equation (1977). The equation uses hourly measurements of solar radiation, air temperature, relative humidity, wind speed, and barometric pressure (BN, 2005d).

\subsection{Wind}

Wind enhances evaporation rates and therefore affects the water balance near ground surface. Wind is also a factor for characterizing atmospheric turbulent mixing. The stability of the air near the ground is used in atmospheric dispersion models that are used to evaluate movement of potential contaminants, including radioactively contaminated soil.

The open and sparsely vegetated Yucca Flat basin is often windy. Wind rose diagrams illustrate source wind direction and the occurrence of wind speed groups using hourly wind data measured at a height of $3.0 \mathrm{~m} \mathrm{(10} \mathrm{ft)} \mathrm{above} \mathrm{ground} \mathrm{surface.} \mathrm{Figure} 14$ summarizes hourly wind direction and velocity collected between 1981 through 2004 from the BJY station in Yucca Flat. It was calm for only 2 percent of the hourly readings during the 23 years of record. The wind most often originates from the northwest, north, or southwest and is most frequently in the 1 to

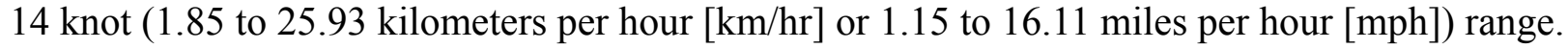




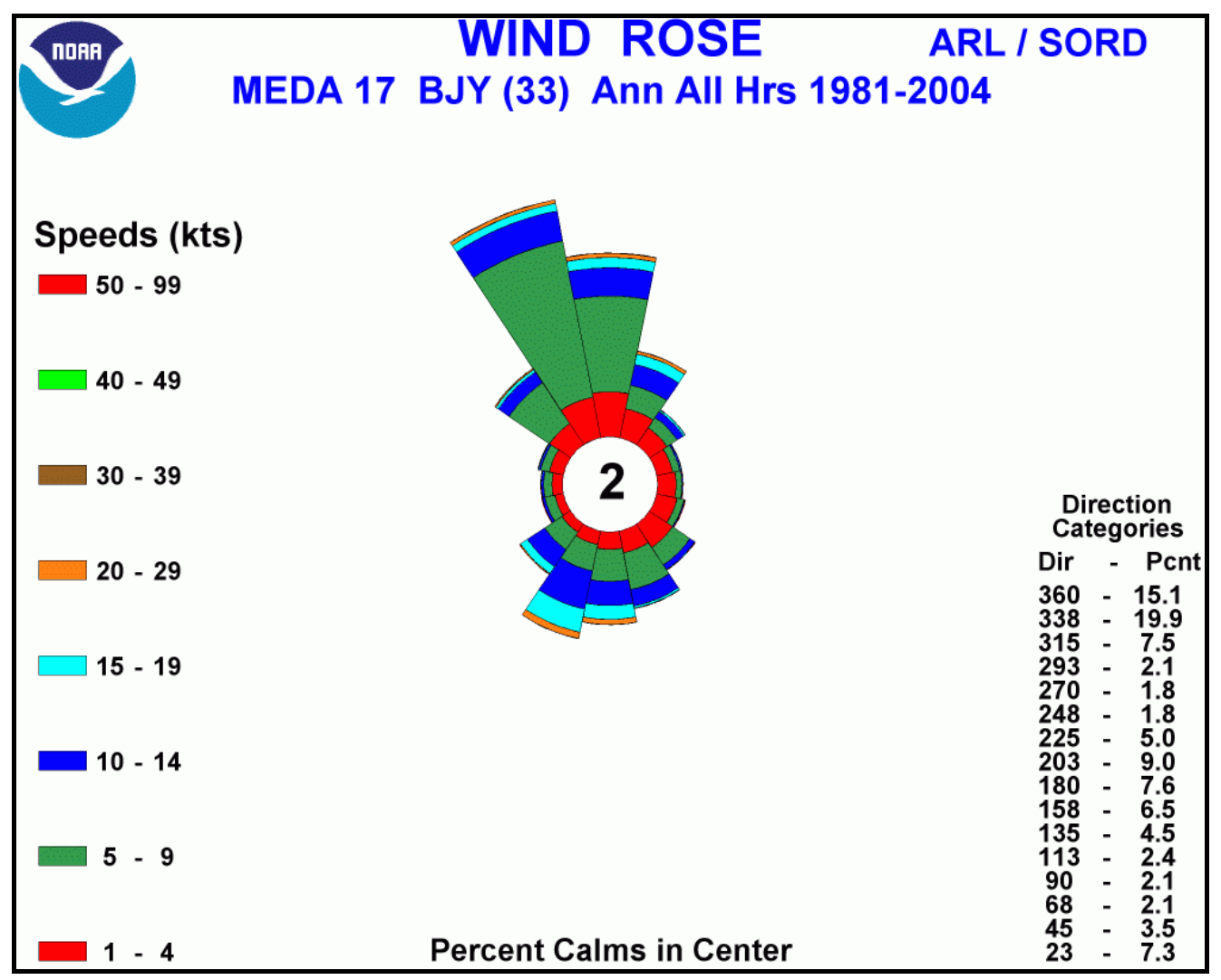

Figure 14

Wind Rose

(Source: Air Resources Laboratory, Special operations and Research Division, undated. Diagram extracted from http://www.sord.nv.doe.gov Web site.)

The highest hourly velocity readings were less than 30 knots $(55.56 \mathrm{~km} / \mathrm{hr}$ or $34.52 \mathrm{mph})$ at this station. In 2004, the average wind speed at the Area 3 RWMS meteorological station was 3.0 meters per second $(\mathrm{m} / \mathrm{s})(6.7 \mathrm{mph})$ and the maximum recorded gust was $20.3 \mathrm{~m} / \mathrm{s}(45.4 \mathrm{mph})$ (BN, 2005d).

There are seasonal and daily wind patterns. In Yucca Flat in the summer, wind is typically from the north between 10 p.m. to 8 a.m. and from the south from 10 a.m. to 8 p.m. In January, the winds are typically from the north from 6 p.m. to 11 a.m., with some southerly winds between 11 a.m. and 5 p.m. The fastest average wind speeds tend to occur in March through June. Peak wind gusts of 80 to $113 \mathrm{kph}(50$ to $70 \mathrm{mph}$ ) have occurred in many areas of the NTS. Higher elevation areas tend to have higher peak wind gusts. Terrain and topography also affect wind patterns at the NTS locally (BN, 2005h). 
This Page Intentionally Left Blank 


\subsection{GEOLOGY}

The structures, stratigraphy, physical, and chemical characteristics of lithologic units constrain potential contaminant and water transport through the subsurface. The USGS, DOE contractors, and other researchers have described the geology of the NTS through many scientific studies. Several bibliographies and general reports briefly summarize the key results of decades of investigations. Useful sources of general geologic information for the Area 3 RWMS include:

- Bibliography of Reports on Studies of the Geology, Hydrogeology and Hydrology at the Nevada Test Site, Nye County, Nevada, from 1951 to 1996 (Seaber et al., 1997) includes bibliographical lists organized by author and by broad subject area.

- Appendix A, Section A.1.1 of the Nevada Test Site Environmental Report 2004 (BN, 2005h) describes the physiographic and geologic setting of the NTS.

- Geology Report, Area 3 Radioactive Waste Management Site DOE/Nevada Test Site, Nye County, Nevada (BN, 1998a) includes results of surficial geologic field studies conducted in FY 1996 and 1997, a literature review and analysis of the Area 3 Fault and East Branch Area 3 Fault, and a summary of local and regional studies of volcanic risk.

- Performance Assessment/Composite Analysis for the Area 3 Radioactive Waste Management Site at the Nevada Test Site, Nye County, Nevada, Revision 2.1 (Shott et al., 2000) includes general information pertinent to potential for contaminant transport and long-term performance of the facility.

Extensive investigations conducted during nuclear testing and recent environmental corrective action investigations characterize the complex regional geology and hydrostratigraphy of Yucca Flat and the impacts of past nuclear experiments on surrounding lithologic units. Researchers recently reviewed data collected from over 1,000 boreholes to develop a hydrostratigraphic framework model of the Yucca Flat region (BN, 2006b).

Since the late 1950s, researchers have drilled hundreds of boreholes and wells within $5 \mathrm{~km}$ ( $3 \mathrm{mi}$ ) miles of the Area 3 RWMS. Although there are no groundwater wells or deep boreholes penetrating the entire vadose zone within the Area 3 RWMS facility, the deeper stratigraphy and structures can be inferred from off-site boreholes. The physical characteristics of the nearsurface alluvium at the Area 3 RWMS were characterized through subsurface studies in the 1990s (see Section 12.1, Hydrogeologic Characterization Study).

General information on regional geologic history, stratigraphy, and structures are presented in Section 9.1. Hydrostratigraphic interpretations and physical and hydrogeologic parameters are presented in Sections 12.0 and 13.0. Potential natural geologic hazards including earthquakes and volcanism are discussed further in Section 10.0.

\section{$9.1 \quad$ Regional Geology}

BN (2006b), BN (2005h), and Shott et al. (2000) briefly summarize the regional geologic history. The complex stratigraphy and structures of the NTS reflect its geologic history. Marine carbonates, shales, sandstones, and conglomerates were deposited in and near shallow seas in the Proterozoic and Paleozoic. These Proterozoic and Paleozoic sedimentary rocks were deformed, folded, and faulted under compression during the Sevier Orogeny. Older rocks were thrust fault 
between 280 and 100 million years ago (Ma) (late Paleozoic Era and most of Mesozoic Era), deformed pre-Tertiary rocks along the western margin of Yucca Flat. Imbricate thrusting in advance of the thrust street created a complex stack of thrust slices. The CP thrust fault formed east of the Belted Range system along an east-dipping high-angle ramp structure. Granitic rocks intruded the deformed Paleozoic rocks in the Mesozoic.

A period of erosion and redeposition occurred in the early Cenozoic. In the middle Cenozoic, there was a period of volcanic activity resulting in deposition of silicious tuffs and lavas and basaltic lavas. The mesas in the northwestern part of the NTS include remnants of the calderas that produced these rocks.

In Miocene to Quaternary times, a period of extensional deformation resulted in development of normal fault-bounded basins and ranges. The basin blocks rotated and dropped with respect to the mountain blocks. The resulting topography characterizes the Basin and Range Physiographic Province in the southwestern United States.

At the NTS, the Basin and Range crustal extension is thought to have occurred in at least two stages. The early phase (about 16 to $14 \mathrm{Ma}$ ) resulted in high-angle, northwest- and northeasttrending normal faults. The second phase (after $11 \mathrm{Ma}$ ) consisted of steeper-dipping north/southtrending normal faults. These normal fault movements began to form the current structural basins.

Generally, movement along west-dipping, high-angle normal faults on the east edges of basins resulted in an eastward tilt of Cenozoic rocks. However reactivation of the earlier CP thrust fault is thought to have resulted in west-tilted Cenozoic rocks in the Yucca Flat structural basin, and the formation of the east-dipping Carpetbag-Topgallant fault system near the center of the present Yucca Flat topographic basin. The Carpetbag-Topgallant fault system forms the eastern edge of a narrow ridge separating the main Yucca Flat basin from a narrow structural basin to the west. Basin development is thought to have continued into the Quaternary (BN, 2006b). Erosion from the mountains has gradually filled the basins with alluvium.

During the late Miocene to the Quaternary, there was no silicious volcanism and very minor basaltic flows near the NTS. There has been no volcanic activity near the Area 3 RWMS since the late Miocene (over $8 \mathrm{Ma}$ ); however, Quaternary basalt flows are present west of the NTS near Yucca Mountain, approximately $42 \mathrm{~km}$ (26 mi) from the Area $3 \mathrm{RWMS}$. The most recent flow in the region, dated to about 80,000 years ago, was southwest of the NTS, at Lathrop Wells.

\subsection{Yucca Flat Stratigraphy and Structures}

Yucca Flat is a fault-bounded structural basin filled with sediment. The mountain ranges and basin basement rock are primarily Paleozoic sedimentary and Tertiary volcanic rock (Shott et al., 2000). The basin is topographically closed. The basin-fill alluvium slopes to the south towards the playa, Yucca Lake. The surface slope at the Area 3 RWMS is about 1 percent (Shott et al., 2000). Figure 15 is a simplified surface geologic map with a few of the major faults. 


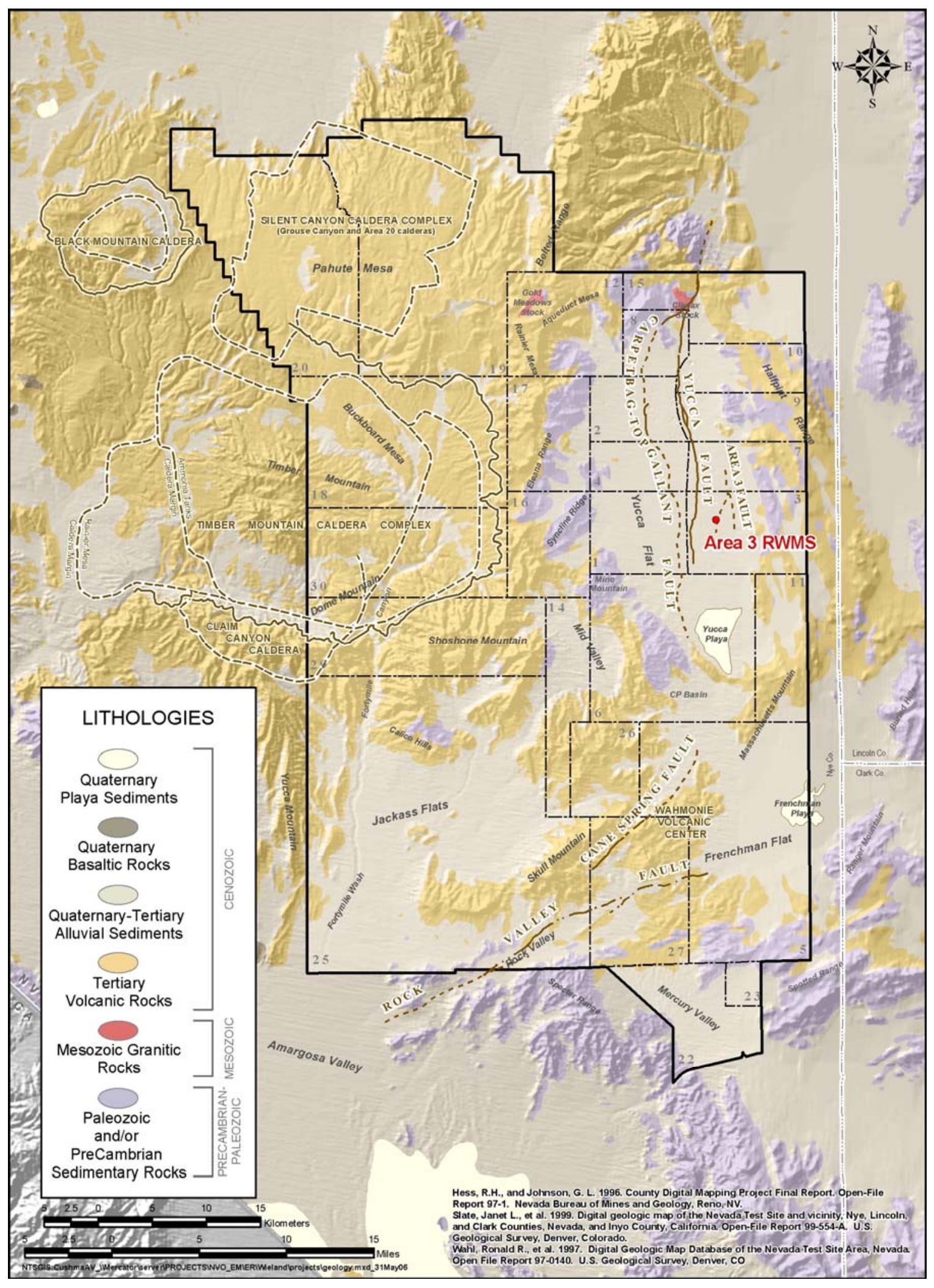

Figure 15

Simplified Geologic Map 
The Area 3 RWMS is on a structural block bounded on the east by the west-dipping Area 3 and East Branch Area 3 Faults and on the west by the east-dipping Yucca Fault. A detailed literature review and data analysis regarding the Area 3 and East Branch Area 3 Faults is presented in the Geology Report (BN, 1998a). The Area 3 Fault has primarily been inferred from explosioninduced fractures and lineaments, and remnants of surface scarps thought to pre-date nuclear testing; however, seismic surveys, borehole data, and gravity surveys do not show conclusive evidence of offsets. Some maps show that the Area 3 fault passes through the east edge of the Area 3 RWMS facility. The Area 3 Fault appears to trend the same direction as surface fractures formed because of nuclear tests, but it is unknown if it was a preexisting tectonic feature reactivated by nuclear testing or if it was originally created because of the nuclear testing (BN, 1998a). Continuity of alloformations in trenches dug across the Area 3 Fault indicates that there has been no vertical displacement since the early Holocene and probably the middle Pleistocene. The lack of major displacement in this time period (possibly over 1 million years), and minimal vertical extent of minor fractures suggest that significant Area 3 Fault movement is unlikely to occur within the 1,000-year regulatory compliance period (BN, 1998a).

Figure 16 shows a simplified stratigraphic section of Yucca Flat at the playa (BN, 2006b). Thick deposits of Tertiary and Quaternary alluvium overlie Miocene volcanics, which overlie carbonates and other basement rock within the basin. These stratigraphic units are generally defined by lithologic characteristics and age. The relationship of these units to hydrostratigraphic units is discussed in Section 13.1, Regional Hydrostratigraphy. Below the Area 3 RWMS, the alluvium is about $300 \mathrm{~m}$ (1,000 ft) thick (Shott et al., 2000).

The complex stratigraphy within the basin has been defined thorough geophysical studies and data from thousands of boreholes drilled over the past 50 years. However, few boreholes near the Area 3 RWMS have been drilled below the Timber Mountain Group, an interbedded layer of ash-flow and bedded tuff ranging in thickness from tens to hundreds of meters where present (Shott et al., 2000). The U-3cn\#5 and ER-3-2 boreholes are less than a mile from the Area 3 RWMS site and provide subsurface information to at least $914.4 \mathrm{~m}(3,000 \mathrm{ft})$ depth. The borehole logs show a thick confining unit of volcanic rock, which acts as a natural aquitard between the shallower, less extensive tuff aquifers and the deeper regional carbonate aquifer. The logs of these deeper boreholes suggest that the distance between the bottom of the shallow waste disposal cells at the Area 3 RWMS and the primary regional carbonate aquifer may be thousands of feet.

Borehole U-3cn\#5, about $1.3 \mathrm{~km}(0.75 \mathrm{mi})$ north of the Area $3 \mathrm{RWMS}$, is one of the deepest boreholes drilled in Yucca Flat. The U-3cn\#5 borehole was completed to a total depth of $924 \mathrm{~m}$ $(3,030 \mathrm{ft})$. At U-3cn\#5, researchers found the top of the Paleozoic carbonates at a depth of $860 \mathrm{~m}(2,821 \mathrm{ft})$ (Shott et al., 2000).

Borehole ER-3-2, located approximately $0.9 \mathrm{~km}(0.6 \mathrm{mi})$ southwest of the Area $3 \mathrm{RWMS}$ boundary, was drilled to a total depth of $914.4 \mathrm{~m}(3,000 \mathrm{ft})$ in 1994. The stratigraphic log indicates $801.9 \mathrm{~m}(2,631 \mathrm{ft})$ of Quaternary and Tertiary alluvium (QTa) overlies Tertiary tuffs of the Timber Mountain Group (see BN, 1999a). The borehole was completed as a monitoring 


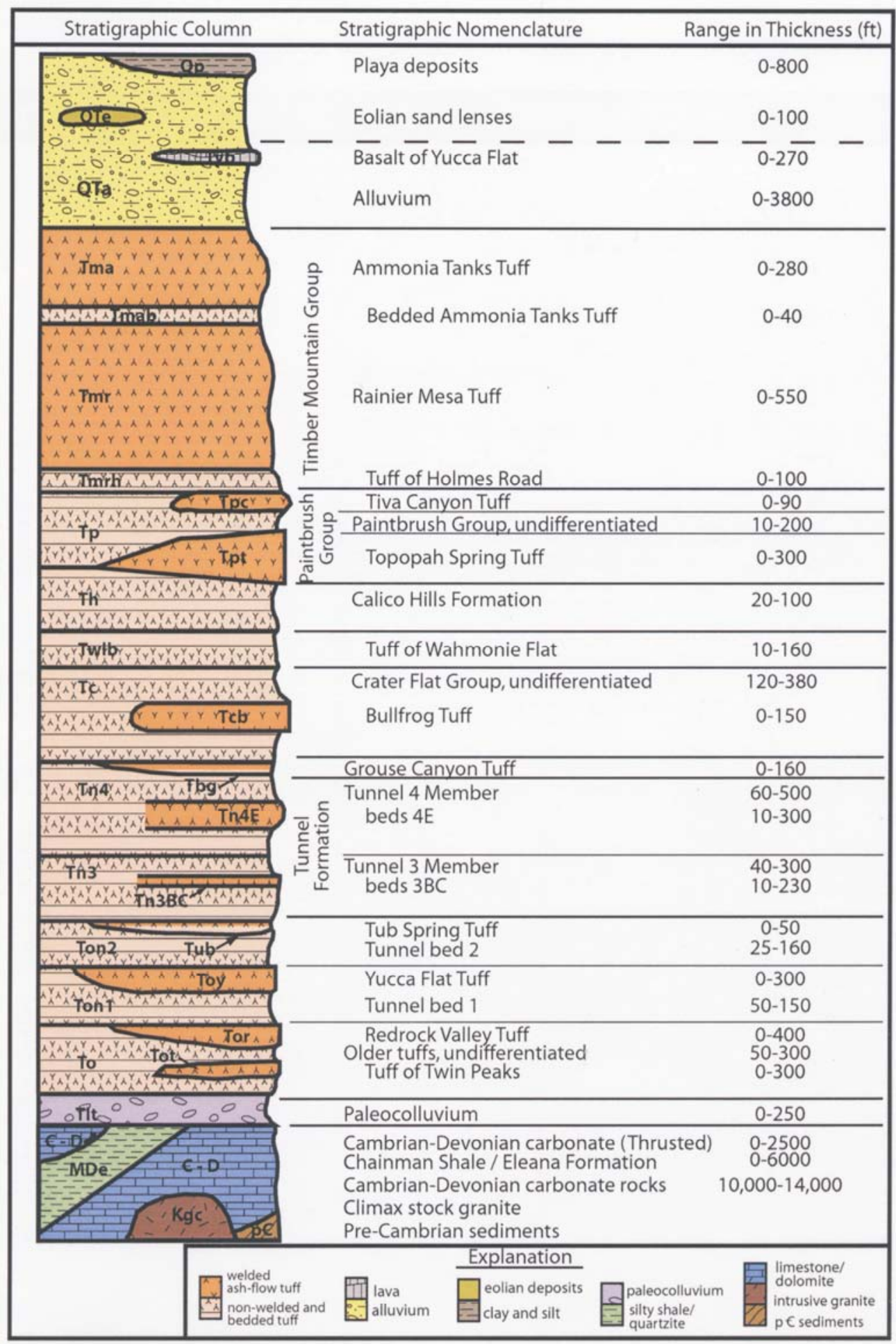

Source: Bechtel Nevada, 2006. A hydrostratigraphic Model and Alternatives for the Groundwater Flow and Contaminant Transport model of Corrective Action 97: Yucca Flat-Climax Mine, Lincoln and Nye Counties, Nevada. DOE/NV/11718--1119. Las Vegas, Nevada, January 2006.

Figure 16 Simplified Stratigraphic Section of Yucca Flat 
well, tapping the volcanic tuff aquifer. Drilling and TDR data indicated a water level depth of $490 \mathrm{~m}(1,608 \mathrm{ft})$. Figure 17 is a reproduction of a west-east geologic cross section through ER-3-2 as presented in BN (1999a). The Paleozoic carbonate rocks are thought to be approximately 1,400 $\mathrm{m}(4,593 \mathrm{ft})$ below ground surface (bgs) at this location.

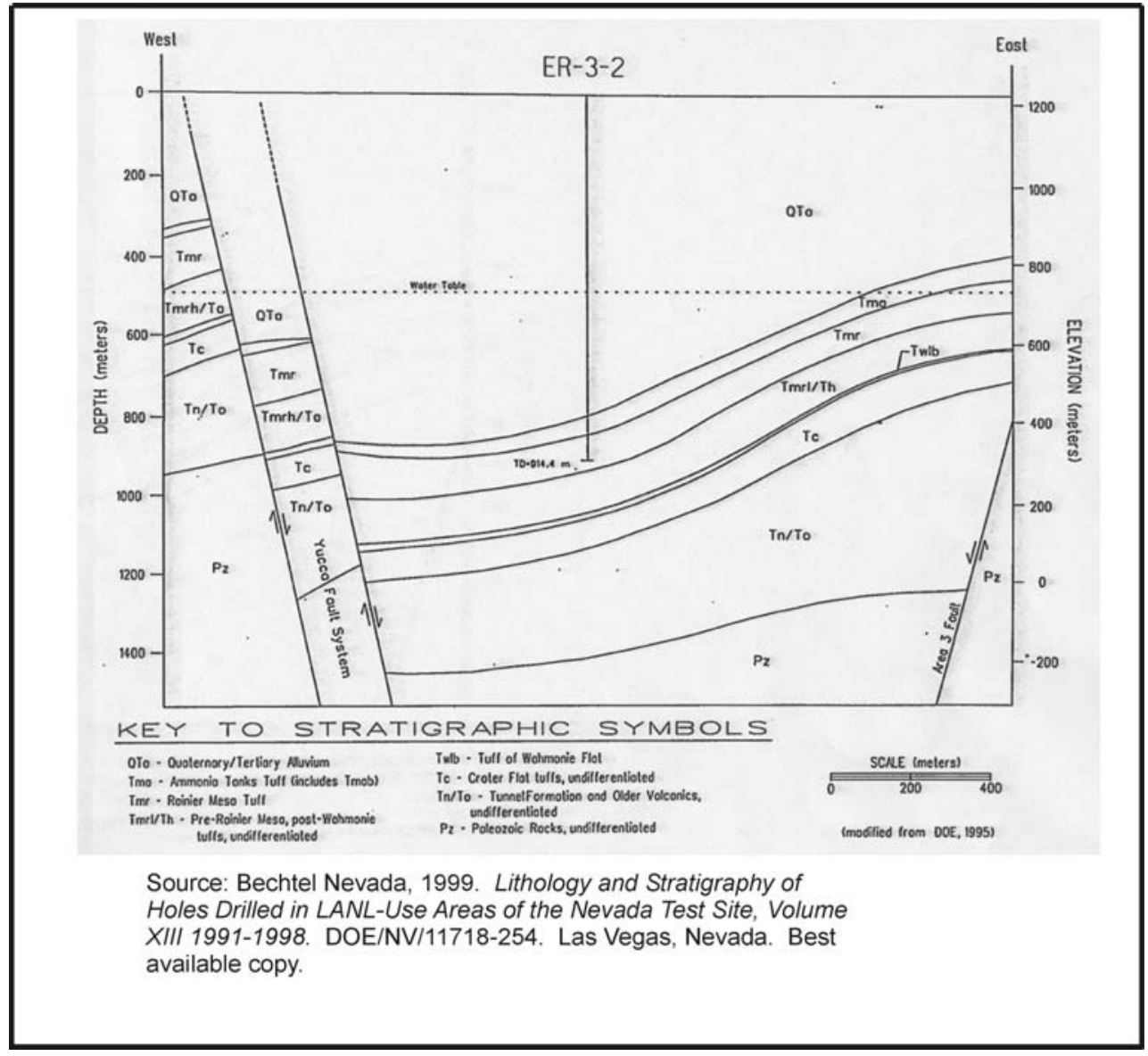

Figure 17

Stratigraphic Cross-Section of Yucca Flat, West-East through Borehole ER-3-2

Regional stratigraphic data indicate that the Area 3 RWMS is situated above a thick section of unsaturated alluvium. The hydrogeologic properties of the upper alluvium are important for evaluating containment performance. Key studies and characteristics are described in Section 12.0, Unsaturated Zone. 
Natural hazards and subsidence are considerations for long-term performance of the facility. The risk of earthquakes, volcanism, and flooding are low. Subsidence is expected. Waste operations and the cover design will help to mitigate the impacts of subsidence on the cover.

\subsection{Seismicity}

Multilayered landfill cell covers have zones of weakness between cover layers that can be disrupted by earth movements. The monolayer-ET design of the existing final U-3ax/bl landfill cell cover and the anticipated similar single-layer design for the final covers at the active $\mathrm{U}-3 \mathrm{ah} / \mathrm{at}$ and $\mathrm{U}-3 \mathrm{bh}$ landfill cells thus provide some intrinsic protection from earthquake damage. At closure, the Area 3 RWMS will have few above-surface structures that could be damaged by earth movements. Damage to fencing, berms, and monitoring stations from shaking is not likely to be significant.

However, fissuring occurred at Yucca Flat in response to past nuclear testing, and the east edge of the Area 3 RWMS facility is also above or adjacent to the Area 3 Fault. Partly because there was concern that large seismic events may have potential to reactivate existing faults or create small fissures in the alluvium, in the late 1990s, BN (1998a) examined evidence of past fault movement in the vicinity of the Area 3 RWMS. The Geology Report, Area 3 Radioactive Waste Management Site, DOE/Nevada Test Site. Nye County Nevada (BN, 1998a) includes a literature and data analysis of unclassified, published and unpublished information regarding the Area 3 and East Branch Area 3 Faults. The report includes a 41-item annotated bibliography spanning 1962 to 1990.

BN (1998a) also excavated trenches and mapped features across the Area 3 Fault to determine if there was evidence of recent fault movement in the shallow subsurface. The investigating geologists concluded that the Area 3 Fault is a plane of weakness that has undergone strain from stress imposed by both past natural events and by underground nuclear testing. Continuity of alloformations in the trenches suggests that there have been no vertical displacements of the Area 3 Fault since the early Holocene and probably since the middle Pleistocene. Minor fractures were observed to have minimal vertical extent. The investigators concluded that “. . . the lack of major displacement within this time frame, and minimal vertical extent of minor features, suggest that waste disposal operations at the Area 3 RWMS will not be substantively impacted by the Area 3 Fault within the regulatory compliance period" (BN, 1998a)

The USGS maintains seismic monitoring stations on and near the NTS. Recent Nevada seismic data can be found at the Web sites of the USGS Earthquake Hazards Program (see http://earthquake.usgs.gov/regional/states.php?region=Nevada) and the Nevada Seismological Laboratory (see www.seismo.unr.edu). The historic record shows that low-magnitude earthquakes are very common at the NTS. Several earthquakes above magnitude 3 on the Richter scale have been recorded. The ICMP (BN, 2005c) and the PA/CA (Shott et al., 2000) briefly summarize past seismic hazard studies. Seismic hazard studies suggest a significant earthquake could occur within the 1,000-year performance compliance period. Shott et al. (1998) calculated the probability that at least one earthquake exceeding magnitude 6.8 on the Richter scale will occur at the NTS in the next 10,000 years to be approximately 0.50 . 


\section{$10.2 \quad$ Volcanism}

Volcanic risk studies indicate that an increase in regional volcanic activity within the next 1,000 years is unlikely (BN, 1998a). Crowe (1990) concluded that the formation of a new volcanic center or cluster of centers would most likely be within the Crater Flat Volcanic Zone. The Area 3 RWMS is about $50 \mathrm{~km}(31 \mathrm{mi})$ from this zone, a thin northwest-trending band that encompasses volcanic rocks dating from about $4.7 \mathrm{Ma}$ to $0.08 \mathrm{Ma}$. The probability of magmatic disruption of the Area 3 RWMS is thought to be less than $3 \times 10^{-9}$ events per year (BN, 1998a using data from Crowe et al., 1998).

The Geology Report (BN, 1998a) examined prospects of future volcanic activity. There are no Pliocene or younger silicic volcanic centers within a 50-km (31-mile) radius of the Area 3 RWMS (BN, 1998a, p. 4). Hazard risk of silicic volcanism occurring during the post-closure 1,000-year compliance period for the Area 3 RWMS is considered negligible.

Hazards of silicic volcanism are considered to be negligible because (Crowe et al., 1983):

- Quaternary silicic volcanism has been restricted to the margins of the Great Basin

- Within the last 10 to 20 million years, there has been a decrease and, in most areas, a cessation of silicic volcanism within the central and southern parts of the Great Basin

- There has been no silicic volcanism in the NTS region for at least 8.5 million years

Another reason that silicic volcanism is unlikely in the near future is that the conditions that provided the source of past silicic volcanism do not currently exist. Past (Cenozoic) silicic volcanism occurred when a tectonic plate margin was subducted, pushed under North America, and melted.

The nearest basalt outcrop to the Area 3 RWMS is the Paiute Ridge basalt, about $6 \mathrm{~km} \mathrm{(4} \mathrm{mi)}$ northeast. The age of this exposed intrusion is about 8.6 Ma. Potassium Argon analysis yielded an age of $8.1 \pm 0.6 \mathrm{Ma}$ for the subsurface basalt unit encountered at borehole UE1h about $5 \mathrm{~km}$ (3.1 mi) from the Area 3 RWMS. No volcanic rocks have been found near or within the NTS that have been dated between 7.3 Ma and 4.7 Ma. The nearest outcrop of Quaternary basalt to the Area 3 RWMS is in Crater Flat, west of the NTS and Yucca Mountain, approximately $51 \mathrm{~km}$ (31 mi) southwest of the Area 3 RWMS (BN, 1998a).

\subsection{Flooding}

BN completed a study to determine if the Area 3 RWMS was within a Federal Emergency Management Agency (FEMA) 100-year flood hazard and to provide estimates of 100-year and 500-year discharges for use in design of flood protection (Miller, 1996). Rainfall/runoff models were used to estimate flood discharges. Curve numbers, depth of precipitation, and lag times were optimized to minimize skew. BN extrapolated the 500-year discharges from the models of 2-, 10-, 25-year, and 100-year return periods. Miller (1996) concluded that the Area 3 RWMS is not located in the FEMA 100-year, 6-hour flood hazard zone of either the Jangle Ridge or Paiute Ridge alluvial fan nearby. Calculated 100-year and 500-year sheetflow depths are less than $0.3 \mathrm{~m}(1 \mathrm{ft})$, so the Area 3 RWMS is also not within 100-year, 6-hour or 500-year, 6-hour sheetflow flood hazard zones. 
Earthen berms surround much of the Area 3 RWMS facility and provide some protection from run-on. Currently, no further flood control structures are required to maintain compliance with DOE facility requirements. An updated flood hazard study is planned for FY 2007, but is not expected to change operations or affect closure of the Area 3 RWMS. 
This Page Intentionally Left Blank 


\subsection{SURFACE WATER}

Surface water is sparse at the NTS and none of it is used for drinking water supply. The Area 3 RWMS is in Yucca Basin, a hydrographically closed sub-basin of the Amargosa sub-basin of the Great Basin. The arid watershed catchment is about $780 \mathrm{~km}^{2}\left(300 \mathrm{mi}^{2}\right)$ (Shott et al., 2000). No surface water flows out. Streams in the region are ephemeral. After precipitation events, runoff collects in the lowest part of the basin on the playa, which is about $8 \mathrm{~km}(5 \mathrm{mi})$ south of the Area 3 RWMS (Shott et al., 2000), and eventually evaporates. For most of the year, Yucca Lake is dry. Locally, natural drainage patterns have been modified by development and past land use including nuclear testing.

Natural perennial surface water is present at several isolated springs at the NTS. The nearest spring to the Area 3 RWMS is Reitman Seep located about $6 \mathrm{~km}$ (4 mi) northeast and upgradient of the Area 3 RWMS, in Area 7 of the NTS (BN, 2005h). Groundwater from the region eventually discharges at springs, located off site of the NTS in Ash Meadows (Laczniak et al., 1996). There are many man-made surface impoundments at the NTS, including sewage lagoons and evaporation ponds, but no active impoundments are located near the Area 3 RWMS. The nearest impoundment is an abandoned reservoir approximately $0.2 \mathrm{~km}(0.1) \mathrm{mi}$. northwest of the Area 3 RWMS (Shott et al., 2000).

The potential for the Area 3 RWMS operations to impact or be impacted by surface water is very low. The margins of the Area 3 RWMS are bermed. These earthen berms mitigate the potential for storm water runoff from surrounding areas to flow into the craters. Potential for runoff away from the craters off site is very low because of the topography. The Area 3 RWMS is not in a 100-Year Flood Hazard Zone (Miller, 1996). Section 10.3, Flooding, has further information. 
This Page Intentionally Left Blank 


\subsection{UNSATURATED ZONE}

The Area 3 RWMS is underlain by a thick, mostly dry vadose zone. At the time of formation, the deepest crater within the area 3 RWMS was only approximately $32.0 \mathrm{~m}(105 \mathrm{ft})$ depth (Planerer, 1996). Depth to water at the Area 3 RWMS is at least $488 \mathrm{~m}(1,600 \mathrm{ft})(\mathrm{BN}, 2005 \mathrm{~d})$. The physical and hydrogeological characteristics of the upper alluvium of the vadose zone and the design of the final cover are significant components of the waste containment system. The arid climate, near-surface water balance, and thick vadose zone prevent recharge and mitigate potential transport of waste contaminants to groundwater. The uppermost part of the vadose zone, the part most relevant to facility performance, has been well characterized.

\subsection{Hydrogeologic Characterization Study}

In the mid-1990s, researchers evaluated hydrogeologic properties of the uppermost part of the unsaturated alluvium at the Area 3 RWMS. A primary objective of this work was to characterize the hydrologic properties of the uppermost part of the disturbed alluvium in the collapse zone between the surface crater and the deep underground test cavity. It had been hypothesized that the alluvium below the craters may have different hydraulic properties than the surrounding, relatively undisturbed alluvium. The study results indicate the alluvium collected from the uppermost part of the collapse zones of U-3at, U-3bh, and U-3bl generally has similar physical properties to samples collected from the undisturbed alluvium. It is assumed that the properties of the collapse zone below the $147.3 \mathrm{~m}$ (483.3 ft) sample depth are similar to the interval characterized. The Area 3 RWMS study provided information required for the conceptual hydrological model. An overview follows.

Seven boreholes were drilled at the Area 3 RWMS facility (Figure 18). Alluvium samples were collected from each boring for testing and analysis. The boreholes are described in Table 11 below. Total vertical depths ranged from $50 \mathrm{~m}$ to $147.3 \mathrm{~m}$ (164 ft to $483.3 \mathrm{ft}) \mathrm{bgs}$.

The researchers collected 19 core samples from an undisturbed area outside of the collapse zones down to a depth of $50 \mathrm{~m}$ (164 ft), 25 samples from adjacent crater walls, 45 samples from the collapse zone of $U-3 b h$, which at the time was an open crater and contained no waste, and 91 samples from intermediate depths within the collapse zones below the waste cells. The interpretation of the boundaries of the collapse zones was based on information about the nuclear tests from LANL and idealized models of collapse chimney shape. The deepest sample thought

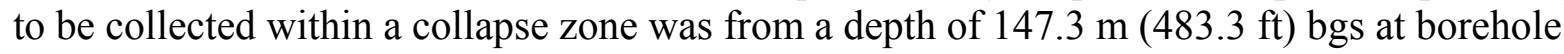
U-3at-D1 (BN, 1998b).

Later, BN (2005g) noted that borehole directional survey data suggest Boring UE-3bl-D1 may or may not have intersected the collapse zone, depending on which idealized model of collapse chimney shape is used. If the chimney was a vertical cone above the cavity, then the boring did not extend deep enough to reach the collapse zone. If the chimney was an inverted cone projected from the edges of the crater down to the cavity, then the boring did intersect the collapse zone. It is not clear from the text of the summary report $(\mathrm{BN}, 1998 \mathrm{~b})$ which way the 


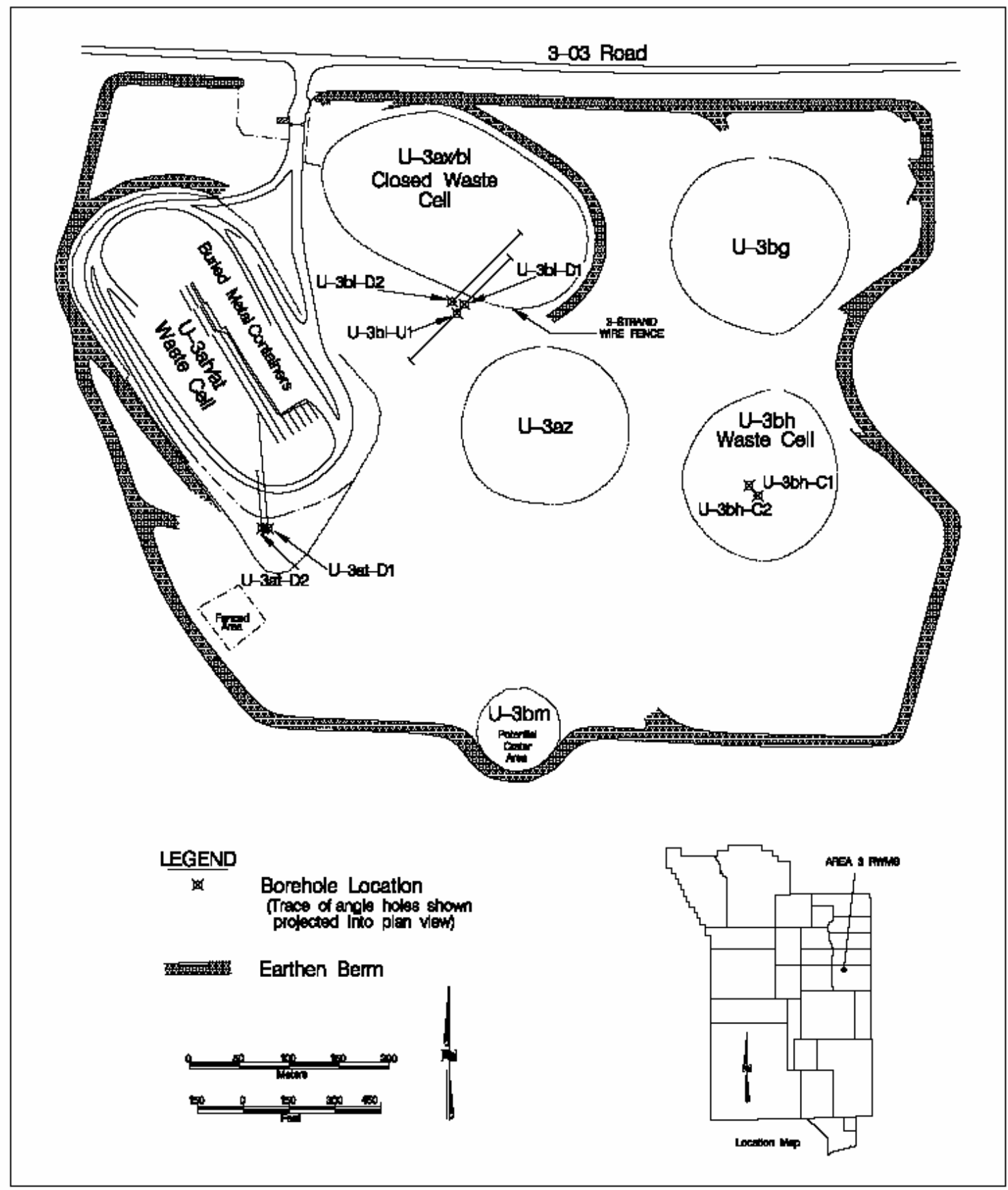

Figure 18

Location of Characterization Boreholes 
Table 11

Area 3 RWMS Characterization Boreholes

\begin{tabular}{|c|c|c|c|l|}
\hline Borehole & Orientation & $\begin{array}{c}\text { Vertical } \\
\text { Depth } \\
\text { (m) }\end{array}$ & $\begin{array}{c}\text { Vertical } \\
\text { Depth } \\
\text { (ft) }\end{array}$ & \multicolumn{1}{|c|}{ Purpose } \\
\hline U-3bh-C1 & Vertical & 64.6 & 212 & $\begin{array}{l}\text { Sample alluvium in the collapse zone below the } \\
\text { crater floor. }\end{array}$ \\
\hline U-3bh-C2 & Vertical & 64.6 & 212 & $\begin{array}{l}\text { Sample alluvium in the collapse zone below the } \\
\text { crater floor. }\end{array}$ \\
\hline U-3bl-D1 & $45^{\circ}$ & 50 & 164 & $\begin{array}{l}\text { Sample alluvium within and outside of the U-3bl } \\
\text { collapse zone. The upper 30 m (vertical) were } \\
\text { deemed undisturbed alluvium. Uncertain if } \\
\text { successfully intercepted the collapse zone. }\end{array}$ \\
\hline U-3bl-D2 & $45^{\circ}$ & 96.6 & 317 & $\begin{array}{l}\text { Sample alluvium within and outside of the U-3bl } \\
\text { collapse zone. }\end{array}$ \\
\hline U-3at-D1 & $35^{\circ}$ or 30** & 147.3 & 483.3 & $\begin{array}{l}\text { Sample alluvium within and outside of the U-3at } \\
\text { collapse zone. The upper 30 m (vertical) were } \\
\text { deemed undisturbed alluvium. }\end{array}$ \\
\hline U-3at-D2 & $30^{\circ}$ & 78.3 & 256.9 & $\begin{array}{l}\text { Sample alluvium within and outside of the U-3at } \\
\text { collapse zone. Drilled and sampled to confirm } \\
\text { that core samples from U-3at-D1 had not been } \\
\text { affected by water condensed in the compressed } \\
\text { air system after indications of moisture were } \\
\text { observed in the 50.9- to 71.6-m interval at } \\
\text { borehole U-3at-D1. }\end{array}$ \\
\hline U-3bl-U1 & $45^{\circ}$ & 50 & 164 & $\begin{array}{l}\text { Drilled away from the U-3bl crater to sample } \\
\text { undisturbed alluvium. }\end{array}$ \\
\hline
\end{tabular}

* Inconsistently described in original data report. 30 degrees per field log in data report.

Sources:

Bechtel Nevada, 2005g. Site Characterization Data from the U3ax/bl Exploratory Boreholes at the Nevada Test Site. DOE/NV/11718--003-REV1. Las Vegas, Nevada. August 2005.

Bechtel Nevada, 2005e. Hydrogeologic Characterization of the U-3at Collapse Zone. DOE/NV/11718--199-Rev.1. Las Vegas, Nevada, August 2005.

Bechtel Nevada, 1998b. Hydrogeologic Characterization of the Unsaturated Zone at the Area 3 Radioactive Waste Management Site, Volume 1 Data Interpretations. DOE/NV/11718-210, UC-721. Las Vegas, Nevada. February 1998.

Bechtel Nevada, 1996a. Hydrogeologic Characterization of U-3bh Collapse Zone. Las Vegas, Nevada. August 1996.

Schmeltzer, J.S., L.E. Barker, and D. O. Blout, 1996. Site Characterization Data from the U3ax/bl Exploratory Boreholes at the Nevada Test Site. DOE/NV/11718-003, UC-702. Bechtel Nevada, Las Vegas, Nevada, April 1996.

samples from this boring were interpreted. A second angle borehole, U-3bl-D2, intercepted the desired interval. Figure 19 shows a profile of the U-3bl-D2 borehole with respect to the potential margins of the collapse zone and cavity of the U-3bl test.

Table 12 summarizes the mean and SD for physical and hydraulic properties and compares the values found for undisturbed alluvium versus the collapse zones below U-3bh and the $\mathrm{U}-3 \mathrm{at} / \mathrm{U}-3 \mathrm{bl}$. U-3bh is distinguished from U-3at and U-3bl because U-3bh was not 


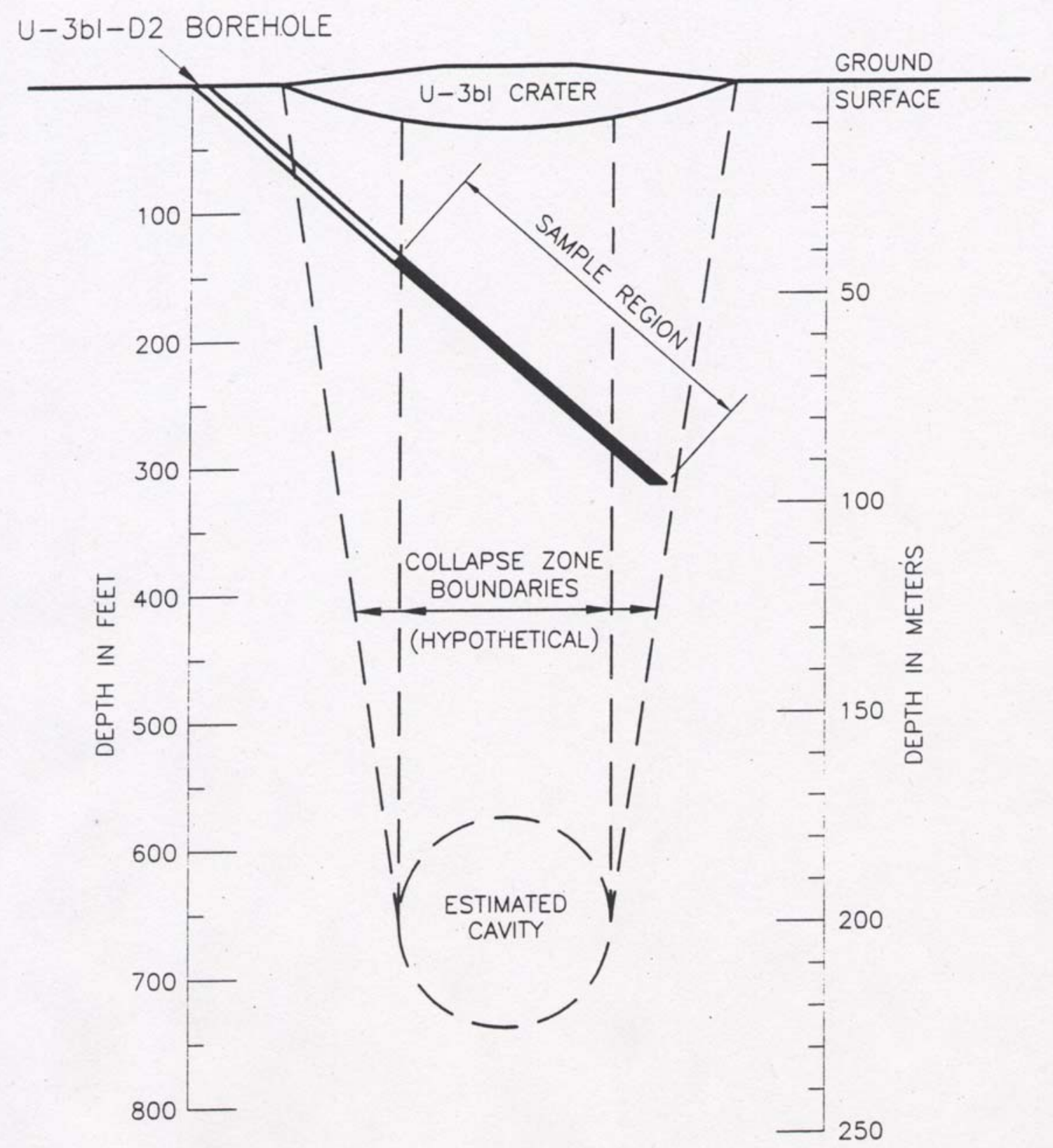

C: \CADD \AREA_3\U3EL_SCH.DWG

Figure 19

Location of U-3bl-D2 Borehole With Respect to Idealized Collapse Zone Boundaries.

(Source: Bechtel Nevada, 1998. Hydrogeologic Characterization of the U-3bl collapse Zone. DOE/NV/11718--197. Las Vegas, Nevada. February 1998. Best available copy.) 
Table 12

Physical and Hydraulic Properties of Area 3 RWMS Characterization Samples

\begin{tabular}{|c|c|c|c|c|c|c|c|c|}
\hline \multirow{2}{*}{ Property } & \multicolumn{2}{|c|}{ Undisturbed } & \multicolumn{2}{|c|}{$\begin{array}{c}\text { U-3bh Collapse } \\
\text { Zone }\end{array}$} & \multicolumn{2}{|c|}{$\begin{array}{l}\text { U-3at and U-3bl } \\
\text { Collapse Zones }\end{array}$} & \multicolumn{2}{|c|}{ Combined } \\
\hline & Mean & SD & Mean & SD & Mean & SD & Mean & SD \\
\hline $\begin{array}{l}\text { Particle Density } \\
{\left[\mathrm{Mg} / \mathrm{m}^{3}\right]}\end{array}$ & 2.49 & 0.0815 & 2.44 & 0.0646 & 2.41 & 0.0876 & 2.44 & 0.0863 \\
\hline $\begin{array}{l}\text { Bulk Density } \\
{\left[\mathrm{Mg} / \mathrm{m}^{3}\right]}\end{array}$ & 1.50 & 0.154 & 1.49 & 0.114 & 1.55 & 0.150 & 1.52 & 0.137 \\
\hline Porosity $\left[\mathrm{m}^{3} / \mathrm{m}^{3}\right]$ & 0.382 & 0.0632 & 0.387 & 0.0466 & 0.364 & 0.0618 & 0.373 & 0.0581 \\
\hline $\begin{array}{l}\text { Sand Fraction } \\
\text { [weight \%] }\end{array}$ & 83.8 & 8.0 & 81.0 & 7.6 & 80.1 & 8.9 & 80.6 & 8.5 \\
\hline $\begin{array}{l}\text { Silt Fraction } \\
\text { [weight \%] }\end{array}$ & 7.3 & 4.2 & 10.2 & 7.3 & 10.3 & 6.8 & 10.1 & 6.8 \\
\hline $\begin{array}{l}\text { Clay Fraction } \\
\text { [weight \%] }\end{array}$ & 8.9 & 4.3 & 8.5 & 2.6 & 9.7 & 4.4 & 9.3 & 4.0 \\
\hline $\begin{array}{l}\text { Natural log } \\
\text { Saturated } \\
\text { Conductivity } \\
{[\mathrm{m} / \mathrm{s}]}\end{array}$ & -11.4 & 1.45 & -11.2 & 1.60 & -12.1 & 1.74 & -11.7 & 1.68 \\
\hline
\end{tabular}

\begin{tabular}{|l|c|c|c|c|c|c|c|c|}
\hline Van Genuchten Parameters: \\
\hline $\begin{array}{l}\text { Natural log of } \alpha \\
{\left[\mathrm{cm}^{-1}\right]}\end{array}$ & -3.34 & 1.37 & -4.42 & 0.89 & -4.42 & 1.06 & -4.18 & 1.18 \\
\hline $\mathrm{n}[$ unitless] & 1.49 & 0.368 & 1.74 & 0.274 & 1.74 & 0.337 & 1.68 & 0.344 \\
\hline$\theta_{\mathrm{r}}\left[\mathrm{m}^{3} / \mathrm{m}^{3}\right]$ & 0.067 & 0.057 & 0.132 & 0.033 & 0.135 & 0.041 & 0.12 & 0.052 \\
\hline
\end{tabular}

$\begin{array}{ll}\text { Notes: } & \\ \mathrm{SD} & \text { standard deviation } \\ \mathrm{Mg} / \mathrm{m}^{3} & \text { megagrams per cubic meter } \\ \mathrm{m}^{3} & \text { cubic meter } \\ \% & \text { percent } \\ \mathrm{m} / \mathrm{s} & \text { meters per second } \\ \mathrm{cm}-1 & 1 / \text { centimeter } \\ \alpha & \text { characteristic inverse length scale } \\ \mathrm{n} & \text { shape factor } \\ \theta_{\mathrm{r}} & \text { residual water content }\end{array}$

Source:

Bechtel Nevada, 1998b. Hydrogeologic Characterization of the Unsaturated Zone at the Area 3 Radioactive Waste Management Site, Volume 1 Data Interpretations. DOE/NV/11718-210, UC-721. Las Vegas, Nevada. February 1998.

developed as a disposal cell until 1997 and represents conditions at the craters before waste emplacement and operational covers. The data show that the physical and hydraulic properties of the upper $147 \mathrm{~m}$ (482 ft) of the collapse zones are generally similar to the alluvium outside of the collapse zones. Saturated hydraulic conductivities and van Genuchten parameter $\alpha$ (characteristic inverse length scale) were found to be lognormally distributed. There were no significant trends with depth for means for particle density, bulk density, porosity, and particle size distribution of the samples of undisturbed alluvium (BN, 1998b). Soil moisture and tracer 
data indicate the extent of past percolation and evapotranspiration. Isotopes yield information on soil water age. Results of this study and vadose zone properties are discussed in more detail later in this chapter.

Some of the characterization boreholes potentially could be used for future monitoring. At least two have been used for moisture monitoring. At the characterization angle boreholes UE-3bl-D1 and UE-3bl-U1, the surface casings have a concrete seal and are capped with waterproof covers. The two boreholes were monitored periodically for soil moisture using a neutron probe until 2000. No instrumentation has been installed and the boreholes remain accessible (BN, 2005g).

Several documents presented the results of the characterization study. The main reports are listed herein and briefly summarized in Appendix A. Schmeltzer et al. (1996) presented initial data from exploratory boreholes at the U-3ax/bl site. The report was put through the DOE Scientific and Technical Information Product process and re-released as Site Characterization Data from the U3ax/bl Exploratory Boreholes at the Nevada Test Site (BN, 2005g).

Hydrogeologic Characterization results were presented in:

Hydrogeologic Characterization of the U-3at Collapse Zone (BN, 1997, 1998e, 2005e)

Hydrogeologic Characterization of the $U$-3bh Collapse Zone (BN, 1996a, 1998c)

Hydrogeologic Characterization of the U-3bl Collapse Zone (BN, 1996b, 1998d)

Hydrogeologic Characterization of the Unsaturated Zone at the Area 3 Radioactive Waste Management Site, Rev 1 (BN, 1998b)

In 1997, the analytical test data for the core samples collected at the boreholes were compiled in a database. The database documentation was published in 2005 as Soil Characterization Database for the Area 3 Radioactive Waste Management Site, Nevada Test Site, Nye County Nevada (Van Remortel et al., 2005). Near-surface soil samples from shallow trenches were also entered into this database.

The following sections summarize some of the other characterization study findings relevant to potential contaminant transport, performance of the containment structure, and closure planning. More detailed discussion is in the data reports listed earlier and the PA/CA.

\subsubsection{Particle Size Distribution and Soil Classification}

Soil classes based on particle size distributions often can be related to physical factors affecting the movement of water and contaminants, including porosity and hydraulic conductivity trends. The uniformity of the lithologies, the stratification, and the lateral extensiveness of layers with different physical characteristics have a significant affect on how liquids, gases, and particles can move through the material.

Based on sieve tests of samples from the seven characterization borings at the Area 3 RWMS, the uppermost $147 \mathrm{~m}$ (482 ft) of alluvium consists of loamy sands to sandy loams under the U.S. Department of Agriculture classification system. No obvious trends with depth were observed (BN, 1998b). Samples from the characterization borings were also characterized by Unified Soil Classification System textural classes. Generally, textural classes ranged from well-graded sand to silty sand. 
Table 12 summarizes mean sand, silt, and clay percentages for subsets of samples from the disturbed collapse zone alluvium and undisturbed alluvium. Mean silt fractions for samples from the collapse zones were about 3 percent higher than the mean silt fractions for undisturbed alluvium samples. At U-3bh, this difference may be due to sediment deposition at the bottom of the crater (BN, 1998b). Sedimentation within the craters can have a significant impact on potential movement of water and contaminants (see 12.2, Other Studies; Wilson et al. [2000] discussion).

Because there are no deep boreholes penetrating the lower half of the vadose zone within the Area 3 RWMS, researchers have looked at data from investigation sites within a few miles of the Area 3 RWMS. Such extrapolations assume that the alluvial characteristics are fairly laterally homogeneous across this region of the basin.

BN (1998b) reported that 17 alluvium samples collected at a depth of $296 \mathrm{~m}$ (971 ft) from the U1a.101 Drift, which is located about $4.8 \mathrm{~km}$ (3 mi) from the Area $3 \mathrm{RWMS}$, contained more silt and clay than the average particle size distribution for the undisturbed and disturbed alluvium characterization samples collected at the Area 3 RWMS down to maximum depth of $148 \mathrm{~m}$ (486 ft).

\subsubsection{Mineral Composition, Geochemistry, and Cation Exchange Capacity}

Mineral composition affects density, which affects how readily alluvial materials will erode. It also can affect soil water chemistry with sufficient residence times. The geochemistry of the native alluvium affects the transport of radionuclides by affecting their solubility and sorption characteristics. Cation exchange capacity (CEC) is the amount of exchangeable ions the soil can absorb in milliequivalents per 100 grams of soil. Generally, the higher the clay content of soils, the higher the CEC, and the greater potential retardation of the movement of certain inorganic contaminants (e.g., lead, cesium, strontium).

The alluvium is generally sandy with variable amounts of silt and clay-size fines. CEC values for samples from borehole UE-3bl-D1 drilled at a 30 degree angle under the waste cell were about one-third greater than the CEC values found for samples from borehole UE-3bl-U1 drilled in undisturbed alluvium. UE-3bl-D1 soil samples may have had a higher fraction of fines; however, the distribution of samples by Unified Soil Classification System names was very similar for the pair of borings. The CEC ranged from 15.8 to 29.4, with a mean of 20.2 for 21 samples from UE-3bl-D1, and ranged from 11.5 to 23.4 with a mean of 15.1 for 23 samples from UE-3bl-U1 (BN, 1996b).

Some of the volcanic tuffs below Yucca Flat contain zeolites as a result of alteration. Zeolites are hydrated aluminosilicate minerals with a porous structure that naturally form where volcanic rocks and ash layers react with alkaline groundwater. Zeolites are able to selectively sorb molecules and ions based on size, and zeolite minerals have high surface areas with many absorption sites. Zeolites naturally remove heavy metals and radioactive species from water and are often used commercially in remediation and containment work. Consequently, the presence of zeolites in the vadose zone below the Area 3 RWMS may provide a natural geochemical impediment to transport of radioactive contaminants. 


\subsubsection{Water Content (Soil Moisture)}

Average volumetric water contents for the U-3bh collapse zone soil samples ranged from 0.13 to 0.19 cubic meter per cubic meter $\left(\mathrm{m}^{3} / \mathrm{m}^{3}\right)$ with water contents of individual samples as high as $0.30 \mathrm{~m}^{3} / \mathrm{m}^{3}$. Detailed water content profiles indicate an overall trend of decreasing water content with depth, superimposed with local peaks. The distribution of soil moisture suggest there were several large infiltration events in the past, but "no indication of increased water content below a depth of $70 \mathrm{~m}(231 \mathrm{ft})$ was found" (Shott et al., 2000).

Average volumetric water contents at the U-3at and U-3bl collapse zones ranged from 0.09 to $0.23 \mathrm{~m}^{3} / \mathrm{m}^{3}$, and individual samples were as high as $0.33 \mathrm{~m}^{3} / \mathrm{m}^{3}$. The variations in water content in the profile are attributed to the layering of horizons with varying permeability. The soil moisture is not "due to current recharge, but is a remnant of recharge during a past cooler, wetter climate" (Shott et al., 2000). Isotopic concentrations in winter rains, which represent precipitation under cooler temperatures, were compared to samples of soil water from the collapse zone samples. The weighted winter mean concentrations of stable isotopes for collapse zone samples

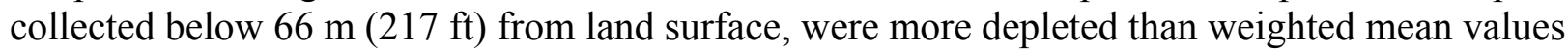
for winter precipitation alone. "These results indicate that the pore water found in the samples from the collapse zones below $66 \mathrm{~m}(217 \mathrm{ft})$ must have infiltrated under cooler past climate conditions" (Shott et al., 2000).

\subsubsection{Water Potential, Water Characteristic Curves, and Unsaturated Hydraulic Conductivity}

Water potential differences help drive the movement of water. Water potential is related to water content by water characteristic curves. The highest potential flow rates are under saturated conditions. At lower moisture levels, the geometry of the small pores, viscosity, surface tension, and other factors increase in importance. Trapped air and vapor in the pores also affect the potential for water movement. Water movement rates in unsaturated conditions are significantly slower than in saturated conditions.

Average matric potential profiles for the undisturbed alluvium samples from the Area 3 RWMS increased from $-6 \mathrm{MPa}$ near the surface to $-1 \mathrm{MPa}$ at $50 \mathrm{~m}(164 \mathrm{ft})$. The near-surface few meters showed the influence of infiltrating precipitation. Below that, a sharp decrease with depth indicates a steady upward flux (BN, 1998b). Tracer profiles also indicated evidence of evaporation in the upper alluvium. For example, the soil moisture found in the soil samples from the characterization borings show a loss of light end isotopes compared to meteoric water.

From about $50 \mathrm{~m}(164 \mathrm{ft})$ to $120 \mathrm{~m}(394 \mathrm{ft}) \mathrm{bgs}$, the matric potential is fairly constant, indicating a static pore water zone. Below about $120 \mathrm{~m}$ (394 ft) bgs, the measured matric potential gradients were high enough for gravity flow. However, estimated vertical flux of moisture in the alluvium below the static zone within the collapse zones of the craters is only 0.35 meters per year $(\mathrm{m} / \mathrm{yr})$, using the highest average water content and mean values of porosity, residual water content, the van Genuchten $\mathrm{n}$ shape factor, and saturated hydraulic conductivity derived from the analysis of samples collected from the U-3at and U-3bl collapse zones (Shott et al., 2000). The deepest alluvial sample collected and analyzed for the characterization study was from a $148 \mathrm{~m}$ (486 ft) depth bgs. It is assumed conditions for gravity flow continue to the groundwater table at about $488 \mathrm{~m}(1,600 \mathrm{ft})$ depth bgs. 
Some of the alluvium core samples from the characterization boreholes in the Area 3 RWMS were tested for hydraulic conductivity over a range of moisture contents. Values of the van Genuchten parameters, which are used to fit a moisture retention curve to the data, appeared to show a trend with depth, but BN (1998b) attributed this apparent trend as an artifact of using different approaches in estimating these parameters with samples from U-3bl-U1 and U-3bl-D1.

Overall, the properties of the uppermost alluvium at the Area 3 RWMS are relatively uniform. The water retention relations (matric potential versus volumetric water content) were typical for soils of sandy texture (e.g., U-3bl-D2). As expected, the siltiest samples generally allowed more water to be held at a given matric potential and generally had lower hydraulic conductivities than the sandier samples.

The measured unsaturated hydraulic conductivities in relation to water content also showed patterns typical of sandy soils. Unsaturated conductivity decreases rapidly as the soil dries. Data from U-3bl are typical. There are no significant trends in water characteristic curves with depth. Variability of moisture content shows differences between alluvium layers (BN, 1998b) and evidence of past episodic infiltration (Shott et al., 2000).

\subsubsection{Effective Permeability}

Effective permeability is a measure of how readily air can move through the alluvium. It is a parameter in evaluating potential transport of gases such as radon. REECo (DOE's contractor) completed air permeability tests on five core samples from borehole UE-3bl-D1 to derive effective permeability. Effective permeability values ranged from $5.9 \times 10^{-13}$ to $1.1 \times 10^{-11} \mathrm{~m}^{2}$. Results from the air permeability test compared to values of effective permeability derived from the saturated conductivity data, yielded similar results, as expected for sandy alluvium. The interaction between the soil and water can reduce permeability (e.g., swelling clays and precipitation), but such interactions are small in sandy soils (BN, 2005g).

\subsubsection{Environmental Tracers}

Environmental tracers are used to estimate vadose-zone water movement, travel times, and recharge. Researchers analyzed samples from the characterization borings to establish profiles for several tracers. Chloride, stable isotopes of oxygen, and tritium were run on most sets of borehole samples from the characterization borings. Due to background tritium residuals from past nuclear testing, tritium was not effective as a tracer for assessing water percolation and estimating pore water age at the Area 3 RWMS. Inorganic carbon distribution and carbonate equivalency evaluations are not tracers, but can corroborate observations of extended evaporative conditions. Development of coatings, nodules, or layers of caliche in the soil can affect transport of water and contaminants.

Chloride and bromide are conservative tracers. Accumulation of chloride and bromide in the near-surface sediments indicates sustained evaporation. Many core samples from the characterization borings at the Area 3 RWMS were analyzed for chloride. Fewer were tested for bromide. The degree of accumulation varied.

The soil chloride profile for borings at U-3bh indicate an accumulation of chloride down to about $45 \mathrm{~m}(148 \mathrm{ft})$ depth. The soil chloride profile for borehole U-3bl-D2 showed little chloride accumulation, yet the calcium chloride equivalent was significantly higher for three samples 
collected from 42.4, 46.0, and $63.4 \mathrm{~m}(139,151$, and $208 \mathrm{ft})$ below the surface. The matrix of the samples was cemented by calcium carbonate and contained weathered caliche fragments (or nodules) (BN, 1998b).

Core samples from the characterization borings were analyzed for stable isotopes of hydrogen and oxygen. Hydrogen and oxygen tracers are part of the water molecules themselves.

Compared to the original rainwater, evaporation results in a preferential reduction in the lightend stable isotopes and an increased proportion of heavy-end stable isotopes in the soil water. The analytical results for the Area 3 RWMS alluvial samples indicated enrichment in heavy isotopes of hydrogen and oxygen in pore water near land surface, attributable to evaporation.

At U-3bh, the effects of evaporation were observed as deep as $45 \mathrm{~m}$ (148.5 ft) bgs. The tracer pattern also reflects the gradual downward movement of storm water runoff (BN, 1998b). Evidence of evaporation extended almost as deep at U-3bl. Core samples collected at U-3bl-D2 below the U-3ax/bl waste disposal cell had very consistent isotope ratios below $39.6 \mathrm{~m} \mathrm{(130} \mathrm{ft),}$ which suggests evaporation is not occurring below that depth. The isotopic compositions also indicated that the samples were more depleted than weighted mean values for NTS winter precipitation. The researchers concluded that the pore water found in samples from the collapse zone below $39.6 \mathrm{~m}$ (130 ft) must have infiltrated in cooler climate conditions (BN, 1998d). BN (1998b) concluded the evaporation rates derived from the stable isotope data reflect the longterm drying of the vadose zone over thousands of years as the system adjusts to the current arid climate.

Deposition of inorganic carbon reflects the geochemistry of the soil and water. Forty-four core samples from UE-3bl-D1 and UE-3bl-U1 were tested for inorganic carbon. The highest values correlated well with the observation of a thin (less than 1 in.) carbonate layer at UE-3bl-D1 and a zone with carbonate coatings on gravel at UE-3bl-U1. There was no evidence of a significant carbonate horizon capable of significantly impeding soil water movement (BN, 2005g).

\subsubsection{Chemical and Radiological Contaminants}

As part of the 1990s characterization of the upper unsaturated zone at the Area 3 RWMS, some alluvium samples were analyzed for potential chemical and radiological contaminants.

The analytical data from samples collected from the two borings drilled at an angle below the closed disposal cell (U-3ax/bl) are relevant to the characterization of the U-3bh and U-3ah/at cells as an indicator of performance of the containment system. Waste disposal records indicate that the U-3ah/at and U-3bh waste disposal cells only received LLW. U-3ax/bl was in operation before the promulgation of RCRA, and received some waste containing hazardous constituents, including lead and cadmium (BN, 1999b).

Selected composite samples of drill cuttings from boreholes U-3bl-D1 and -D2 representing 12-m (40-ft) drilled intervals were analyzed for ${ }^{239+240} \mathrm{Pu}$, gamma emitters, tritium, RCRAregulated metals, and semivolatile organic compounds for the purpose of waste characterization for disposal of the cuttings. Volatile organic compounds (VOCs) were not evaluated because the drilling method used pressurized air and any VOCs present would be likely to volatilize before sample collection. 
No RCRA-regulated materials or radioactive materials above background were found in any of the samples with the exception of small concentrations of tritium. The tritium concentrations were less than 1 percent of the Nuclear Regulatory Commission's limit for effluent released to an unrestricted area (Title 10 CFR 20): $1 \times 10^{6} \mathrm{pCi} / \mathrm{L}(\mathrm{BN}, 2005 \mathrm{~g})$ and were of no environmental concern (CFR, 1991).

The site characterization researchers concluded that "... wastes have not migrated significantly" (BN, 1999b). They also concluded the operational cover would be adequate to accommodate episodic infiltration events, evaporation, and most of the plant and animal activity, but recommended installing a final natural alluvium monolayer cover that will help mitigate the effects of future subsidence.

The distribution and levels of tritium found in soil samples from the seven characterization borings drilled at the Area 3 RWMS suggest that the tritium is from past nuclear testing. Results from some borings are attributed to tritium movement upward through the vadose zone away from the test cavity. Results at others, particularly U-3bh, may show evidence of tritium infiltrating with water. For detailed discussion, see the characterization reports (e.g., BN, 1998b, 1998c, 1998d, and 1998e; 1997b; 1996a, 1996b).

Tritium concentrations were measured in 29 core samples collected in the interval between approximately $42.3 \mathrm{~m}$ (139 ft) depth and $96.5 \mathrm{~m}$ (317 ft) depth from U-3bl-D2. The tritium profile with depth below ground surface shows a gradual decline in tritium levels from $5,880 \mathrm{pCi} / \mathrm{L}$ at $42.3 \mathrm{~m}(139 \mathrm{ft})$ depth to $2,680 \mathrm{pCi} / \mathrm{L}$ at $51.8 \mathrm{~m}(170 \mathrm{ft}) \mathrm{depth}$, then a general increase in tritium levels with a peak of $12,150 \mathrm{pCi} / \mathrm{L}$ found at $75 \mathrm{~m}(246 \mathrm{ft}) \mathrm{depth}$, and then an overall decrease in tritium concentrations with depth in the samples from the bottom $20 \mathrm{~m}(66 \mathrm{ft})$ of the borehole. Smaller fluctuations may reflect layering of the alluvium. BN (1998b, 1998d) concluded that the observed concentrations of tritium in soil at this borehole were two to three orders of magnitude higher than expected from atmospheric deposition of tritium, and the tritium was most likely a product of nuclear testing.

Tritium concentrations were measured in 55 samples collected between $7.94 \mathrm{~m}$ and $146.93 \mathrm{~m}$ (26 ft and $482 \mathrm{ft}$ ) bgs at boring U-3at-D1. Between the surface and about $119 \mathrm{~m}(390 \mathrm{ft})$ depth, concentrations of tritium were below the detection limits, which ranged from 226 to $312 \mathrm{pCi} / \mathrm{L}$

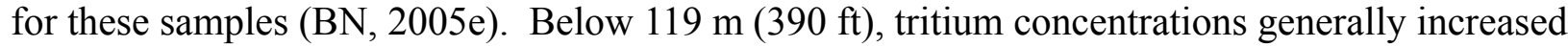
with depth. The highest concentration was detected in the deepest sample, 2,200 pCi/L at 146.93-m (482.0-ft) depth. BN (1998e) attributed this tritium to underground nuclear testing. A detailed review of the characterization data and development of a tritium dispersion model were presented in the characterization report for the closed cell U-3ax/bl, CAU 110 (BN, 1999b).

A second angle boring was drilled below the U-3at crater (U-3at-D2) to confirm that core samples collected from 50.9 to $71.6 \mathrm{~m}$ (16.7 to $235 \mathrm{ft}) \mathrm{bgs}$ at U-3at-D1 had not been impacted by the addition of fluids during drilling. Tritium concentrations were measured in seven cores collected between approximately 47.64 and $63.51 \mathrm{~m}$ (156 and $208 \mathrm{ft}$ ) depth bgs from U-3at-D2 (BN, 1998e). The tritium profile at this borehole was very uniform with depth, with no concentrations found above the detection limits.

Shott et al. (2000, Appendix A1) and BN (1996a, 1998c, 1998b) interpret in detail the hydrogeological results for the characterization borings drilled at U-3bh. Tritium and potential data with respect to depth for the two characterization boreholes drilled and sampled at U-3bh 
are presented in $\mathrm{BN}(1998 \mathrm{c})$. Borehole $\mathrm{U}-3 \mathrm{bh}-\mathrm{C} 1$ results suggest that there was a pulse of tritium transported with infiltrating water to a depth of $69 \mathrm{~m}(226 \mathrm{ft})$ during the 33 years between the nuclear testing and the characterization study testing. At U-3bh-C2, there appears to be three distinct pulses of tritium transport downward. The researchers concluded that there is a zone varying 10 to $20 \mathrm{~m}$ ( 33 to $66 \mathrm{ft}$ ) below the crater floor that appears to have had a high frequency of infiltration events represented by alternating zones of depletion and enrichment of stable isotopes with depth. There is then an interval of about $40 \mathrm{~m}(131 \mathrm{ft})$ characterized by higher water contents that is slowly redistributing.

Although there is evidence of past infiltration at U-3bh, the potential for further transport through the vadose zone is mitigated by current site conditions. DOE subsequently developed the waste disposal cell at U-3bh. The waste deposits and operational covers have significantly reduced the potential for further infiltration through the base of the crater. Furthermore, an unsaturated flow model was used to evaluate potential for recharge (see discussion in Section 6.1, Hydrogeologic Conceptual Model for the Area 3 RWMS), and the results indicate that after closure of the landfill during the period of institutional control, little water movement would occur (Shott et al., 2000, Appendix A1).

\subsection{Other Studies}

The Geology Report, Area 3 Radioactive Waste Management Site, DOE/Nevada Test Site, Nye County, Nevada (BN, 1998a) includes information pertinent to characterization of the vadose zone properties and processes. The report includes an updated geomorphic surface map, crosssections of trenches dug across the Area 3 fault showing detailed allostratigraphic units and structures, an assessment of fault movements, and a map of post-test event test-induced surface fractures. Data from soils samples collected at the trenches are presented in the soil database (Van Remortel et al., 2005). This study is discussed further in the Geology and Natural Hazards sections of this report.

The Area 3 RWMS operational covers consist of similar alluvium and were emplaced by similar methods as the Area 5 RWMS operational covers. A study of the properties of some of the existing soil covers at the 92-acre area of the Area 5 RWMS concluded that the physical properties of the soil covers, which were derived from local alluvium, were very similar to the properties of the surrounding undisturbed alluvium. A summary of the analytical results is in the Area 5 RWMS Characterization Report (BN, 2006c).

Records from the tests provide some characterization data for the deeper layers of unsaturated alluvium at the Area 3 RWMS. For example, postshot drilling records for U-3at indicate that there was a loss of drilling mud circulation at a similar depth in all three postshot boreholes suggesting the presence of a high-porosity or high-permeability zone within the collapse zone somewhere between 231.6 and $246.9 \mathrm{~m} \mathrm{(760} \mathrm{and} 810 \mathrm{ft}$ ) depth (Planerer [1996], as cited in BN [2005e]).

Boring logs and analytical data from investigations of other sites at Yucca Flat provide some insight into the properties and stratigraphy of deeper lithologic units. Deep boreholes nearby include U-3cn\#5 and U1a. Borehole U-3cn\#5, located approximately $1.3 \mathrm{~km}(0.75 \mathrm{mi})$ north of

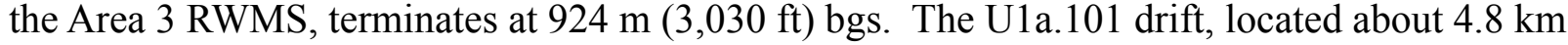
(3 mi) from the Area 3 RWMS, extends $305 \mathrm{~m}$ (1,000 ft) (BN, 2005e). 
The PA/CA and ICMP cite many studies that describe vadose zone processes and characteristics. Section 6.1 briefly discusses the hydrogeologic conceptual model. There are also many studies of structures and features elsewhere at the NTS with potential relevance to vadose zone processes at the Area 3 RWMS. For example, Wilson et al. (2000), building on work by Hockett and French (1998), evaluated recharge at the U-5a subsidence crater in Frenchman Flat in Area 5. This crater was selected as a worst-case example because it had high runoff into the crater and deposits of finer sediments. There also was physical evidence of a large ponding event after crater formation, including a high water mark, gullies, and a coarsening downward sediment profile.

One objective of the Area 5 crater study was to evaluate if the presence of a fine-grained playa region within a crater would focus infiltration outward through the surrounding coarser-grained material, thereby increasing infiltration rates and potentially the potential for recharge. It was hypothesized that if the surface runoff covered only the crater playa area, the low permeability surface would restrict percolation.

The researchers measured hydraulic properties along a transect outside of and within the crater. They used water-flow simulations created with HYDRUS 2-D to model the wetting front advance and potential recharge for various ponding scenarios.

Depth to water at U-5a in Frenchman Flat is much shallower than at the Area 3 RWMS, only $206 \mathrm{~m}$ (676 ft) bgs. For a very large ponding event, simulations predicted potential for recharge in 32 years, but the properties of sediments around the playa perimeter were shown to effectively restrict future recharge by storing water until removal by evapotranspiration. The hydraulic properties of the coarsening downward sequence effectively prohibited recharge from subsequent ponding events. The researchers concluded that subsidence craters may be "self-healing"

through the deposition of sediment and establishment of vegetation (Wilson et al., 2000 [see Abstract]). At the Area 3 RWMS, characterization studies suggest that there is a finer sediment deposit at U-3bh. The fines may slow down and redistribute flow, if any.

BN (1998b) and Shott et al. (2000) identified potential transport processes. Potential transport processes in the vadose zone following closure of the waste disposal cells are thought to include advection and diffusion of gaseous radionuclides, upward advection and diffusion of solutes, plant uptake, and bioturbation. Radionuclides may eventually accumulate in the surface layer of the cap and be released to the atmosphere. Gas and liquid-phase diffusion may occur below the waste. Erosion of the cover by wind and surface water flood events could move contaminated sediments and plant residue away from the waste deposits. Over a longer time frame, sediment is likely to be deposited within the craters and on top of the landfill covers if the final cover is below the crater rim.

Section 12.3, Potential Preferential Pathways, discusses features identified during characterization of the upper vadose zone that may provide preferred pathways, including potentially unplugged boreholes and surface fissures. The following sections summarize characteristics of the shallow to intermediate vadose zone in the vicinity of the Area 3 RWMS. 


\subsection{Potential Preferential Pathways}

Several potential preferential pathways for movement of water or contaminants through the upper vadose zone have been identified over the years. Some have been investigated further through characterization investigations. Despite the presence of multiple near-surface features, there are no confirmed significant pathways that would appreciably accelerate percolation through the thick vadose zone. The likelihood of future groundwater impacts from the operation of the Area 3 RWMS are considered to be low.

In the late 1990s, BN, with input from LANL, reviewed historic data records for at least four nuclear tests to identify locations and status of diagnostic cables, metal cables, conductor casing, boreholes, and other installations associated with the tests that might provide preferential pathways for water or contaminants to move through the upper vadose zone within the Area 3 RWMS (BN, 1998b). A data review prepared in 1994 by Ward L. Hawkins of LANL, and included as Appendix A within the BN report "Hydrogeologic Characterization of U-3bh Collapse Zone" (BN, 1996a), notes that tests at U-3ah and at U-3bg "seeped small amounts of radiation to the ground surface at the test location." This suggests that in the early 1960s, there was at least a temporary pathway for contaminants to reach the ground surface from the test cavity at these two test sites within the Area 3 RWMS.

The BN unsaturated zone study (1998b) concluded that there were 37 downhole cables used for U-3at, 23 for U-3ax, and 38 for U-3bl. No cable information was found for U-3bh. Although there is evidence that cables were pathways for movement of gases under high pressure during some NTS nuclear tests, it is unknown if downhole gas blocks in cables or cable fanouts for these particular holes were used. It is uncertain if the cable remnants at the Area 3 RWMS provide a preferential pathway for the movement of water today.

BN implemented a formal borehole abandonment program at the NTS in 2001 to plug test boreholes and wells that are no longer needed by projects at the NTS. Based on a review of records, approximately 700 wells and boreholes were identified for abandonment. Within the set of boreholes and wells identified for abandonment, prioritization is based on anticipated future use of the vicinity, containment needs, accessibility, and other factors. Although how each borehole is plugged varies with local conditions and programmatic needs, the plugging procedure used at each borehole or well exceeds the Nevada regulatory requirements (Nevada Administrative Code 534.420, Plugging of Well: General Requirements [1997]). Nevada requires a $20-\mathrm{ft}$ cement surface seal, and a seal at the water table if the well or borehole intercepts the water table. Many of the boreholes plugged before initiation of the formal plugging program, and early in the formal program, were completely cemented from the bottom depth to ground surface. Currently, many of the boreholes are cemented $300 \mathrm{ft}$ or more from ground surface. The cement is tremied to ensure no gaps in the seal (personal communications, Gustafson and Wharton to Wieland, 2006).

In the past, researchers at the NTS set shallow conductor casing, typically to $24 \mathrm{~m}(80 \mathrm{ft})$ bgs, in "pre-postshot" holes prior to the nuclear test detonation to help reduce the time to drill "postshot" test holes after the detonation. Sometimes not all of the pre-postshot locations were drilled out for postshot investigations. Some of these shallow pre-postshot locations have been found to have no cap when they were exposed for abandonment. Generally, the postshot 
boreholes are found capped with a blind flange or welded cap. Sometimes, hardware or instrumentation is found in the postshot boreholes and sometimes there is evidence of sloughing of material from sidewalls into the borehole (personal communications, Gustafson and Wharton to Wieland, 2006).

At the U-3at, U-3bh, U-3ax, and U-3bl sites, test researchers backfilled the instrumented satellite holes with sand pack to a certain thickness above the instruments, and then cemented from the sand pack on up to ground surface (BN, 1998b). Three 12-m- (39-ft)-deep instrument holes (U-3bh-1, U-3bh2, and U-3bh3) were cemented, capped, and abandoned without being instrumented prior to the test (BN 1996a). The emplacement holes were stemmed with sand pack. A borehole database maintained by BN (informally known as the "Red Book") indicates that the vertical emplacement holes at the seven craters within the Area 3 RWMS were "expended" or essentially destroyed by the test detonations and subsequent collapse of earth above the device (personal communication, Obi to Wieland, 2006).

Figure 20 shows the abandonment status of test and characterization boreholes, based on data extracted from the Red Book database on April 10, 2006 (personal communication, Obi to Wieland, 2006). Boreholes identified as "active" means that there is no record of the borehole being plugged or expended in the database. The "active" borehole or well is either in active use for monitoring or other uses, was capped to allow for future access, or was abandoned many years ago but no records confirming the plugging have been found.

At the Area 3 RWMS, the condition of the postshot holes within the subsidence craters below the waste cells is unknown. Because of the waste deposits, these boreholes are not accessible to inspect their condition and plug them. Many boreholes within the Area 3 RWMS from the 1960s nuclear tests and some of the characterization borings from the 1990s vadose zone investigations have already been plugged. Some of the characterization borings were capped to allow future access for neutron logging or other purposes.

Ward L. Hawkins of LANL noted in a 1994 data review included as an appendix within BN (1996a) that two of the four vertical postshot holes in the U-3bh crater were abandoned because of drilling problems; however, there are no specific records. Common practice at the time was to install a welded cap, blind flange, or slide valve on the top of the casing.

Under the current plugging program within the Area 3 RWMS, abandonment of at least two of the pre-postshot holes (U-3ax PPS \#3 and U-3ax PPS \#4) was postponed because of their location next to the landfill roadway. The Area 3 RWMS roadway was being used actively at the time they were plugging boreholes in this region. Abandonment of at least one surface borehole also has been postponed because of an active electrical line in the proposed work area. For safety and other reasons, access to each of the subsidence craters at the NTS requires permission from LANL. Although they will be plugged eventually, there are boreholes elsewhere at the NTS that have a higher priority for plugging than the remaining "active" boreholes within the Area 3 RWMS (personal communication, Gustafson to Wieland, 2006). 


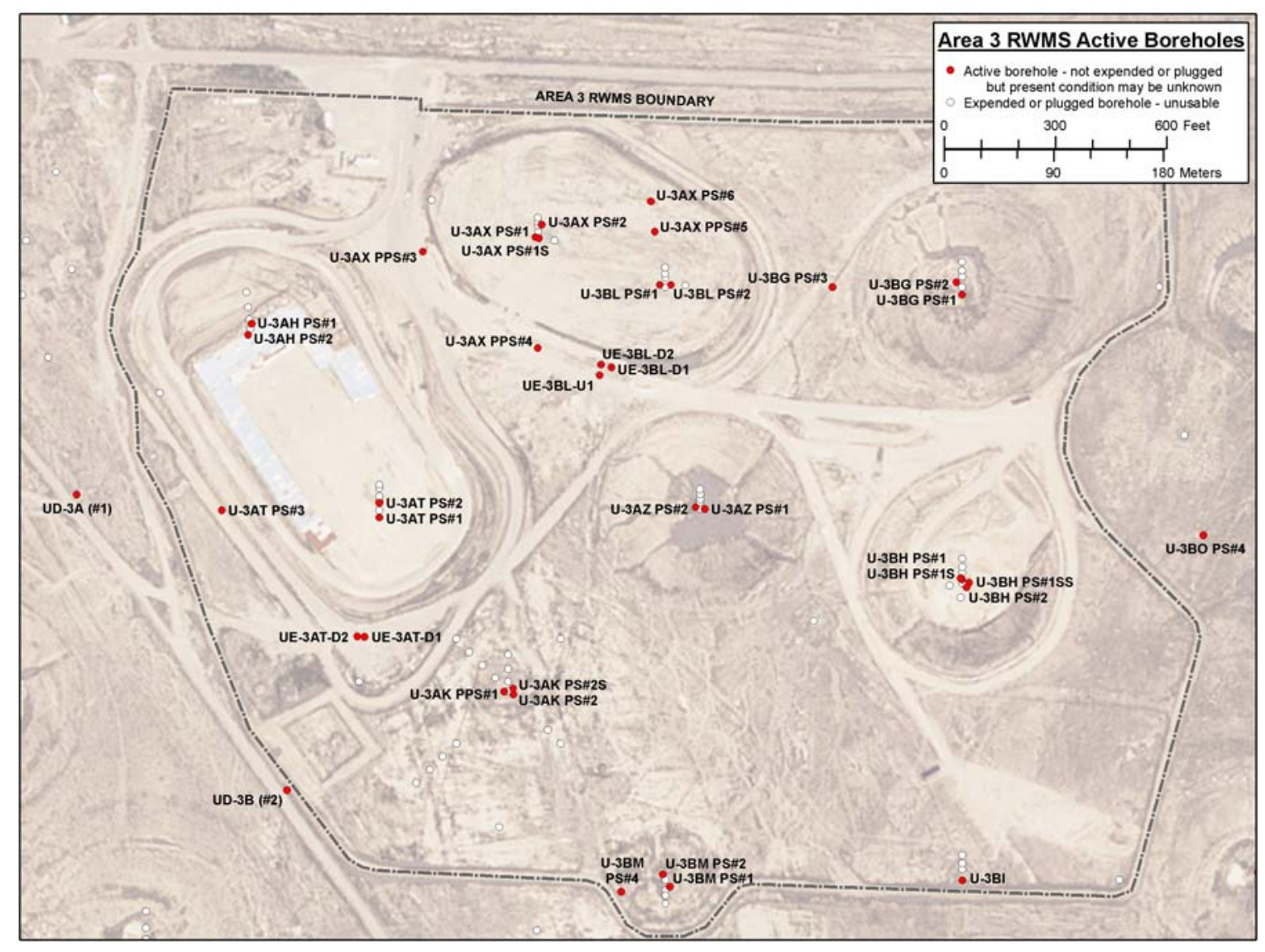

Figure 20

Status of Boreholes in the Area 3 RWMS as of April 10, 2006

The site-specific potential for contaminant transport via these potential upper alluvium preferred pathways has not specifically been assessed or estimated to date; however, no significant further investigation is required because other aspects of the site setting effectively mitigate potential significant transport of contaminants away from the waste deposits. If funding were available, additional conservative modeling runs could potentially provide a worst-case indicator of the effects of preferred pathways, but such modeling is not essential to proceed with closure planning.

Fractures are another type of potential preferred pathway. Surficial geologic studies near the Area 3 RWMS were conducted in FY 1996 and 1997 to determine if future movements along the Area 3 Fault would adversely affect the waste disposal operations of the Area 3 RWMS. The conclusion was that significant movement along the fault in the next 1,000 years was unlikely (see seismic hazard discussion in Section 10.1 of this report for further detail). However, the Geology Report (BN, 1998a) does not discuss if the fault could be an impediment or preferred pathway for infiltrating water.

The Geology Report (BN, 1998a) also provides maps of historic observations of natural and test-induced fractures and lineaments in the Area 3 RWMS vicinity. The depth and current status of these features is unknown. Fractures in unconsolidated alluvium can open and close over time and the surface expression of past features can be obscured by natural processes. It is unknown if any of these features are still observable. The Geology Report (BN, 1998a [Plate 2]) includes 
a map of testing-induced fractures used to help delineate the location of the Area 3 Fault. This map indicates that some historically mapped fractures (apparently associated with testing activities outside of the Area 3 RWMS) extend within the southeast corner of the Area 3 RWMS facility, south of U-3bh.

The Geology Report (BN, 1998a [Plate 4]) also presents a map of pre-testing lineaments and geophysically inferred faults compiled from studies published between 1963 and 1972. The map indicates a set of northeast- to northwest-trending lineaments were identified passing through the current RWMS facility area east of U-3bl, less than $457 \mathrm{~m}(1,500 \mathrm{ft})$ west from the surface trace of the Area 3 fault.

Kao et al. (1994) described fracturing in alluvial soils, past and recent field observations of fractures in Yucca Flat (particularly along the Carpetbag fault and at Yucca Lake), and described possible infiltration behavior. They noted that most of the historic fracture investigations involved fractures less than $20 \mathrm{~m}$ (66 ft) deep. The study noted that Yucca Fault fractures are dynamic: they open and seal, and appear and disappear.

Although shallow surface fractures may provide preferential pathways for infiltration and percolation of surface runoff, they are not likely to significantly affect performance of the Area 3 RWMS. Fractures in unconsolidated alluvium are unlikely to propagate to great depth and also have a tendency to heal over time. Many of the lineaments mapped in the 1960s and early 1970s and attributed to testing have no surface expression today. The nature of the waste, the containers, the arid climate, the physical properties of the alluvium, and other factors help mitigate the potential impacts of surface fracture flow. Further characterization of the surface fractures from nuclear tests in the 1960s does not appear to be necessary to proceed with closure planning for the facility.

\subsection{Water Balance Monitoring and Cover Performance}

Data from the automated waste cover monitoring system at U-3ax/bl indicates the monolayer-ET cover is effective at protecting the waste from infiltrating storm water, and is an indicator of the future performance of similar final covers planned for U-3bh and U-3ah/at. The Area 3 and Area 5 lysimeters are representative analogs for moisture movement through the landfill covers. Further direct instrumentation of landfill covers may not be necessary to demonstrate cover performance (BN, 2005c).

\subsubsection{Automated Waste Cover Monitoring System}

In 2000, BN installed an automated vadose monitoring system at the Area 3 RWMS for evaluating the performance of the U-3ax/bl cover. The system consists of two data loggers, each wired to two arrays of eight TDR probes. Each array nest consists of eight TDR sensors buried at approximately 30-cm (1-ft) intervals starting at about $30 \mathrm{~cm}(1 \mathrm{ft})$ depth down to about $244 \mathrm{~cm}$ $(8 \mathrm{ft})$ depth within the earthen cover. Details of the installation are in the closure plan and closure report for U-3ax/bl (DOE, 2000a; NNSA/NSO, 2001). Figures 5 and 6 in Section 4.0, Monitoring Programs, show the location of monitoring stations at the Area 3 RWMS. The vadose zone stations labeled on Figure 5 are the locations of the surface data loggers. The sensor array nests are not presented on this large-scale depiction. Figure 6 shows the approximate locations of the four nests within the cover. 
Data from the automated cover monitoring system at U-3ax/bl indicate that the vegetated earthen cover has been effective at protecting the waste from infiltrating storm water. Soil moisture content measurements on the $\mathrm{U}-3 \mathrm{x} / \mathrm{bl}$ cover declined as the vegetation became established and grew. Maximum observed percolation depth occurred when the cover was irrigated to enhance survival of seedlings and transplants, before a normal plant cover percentage had been established. Moisture from the irrigation and precipitation percolated approximately $2 \mathrm{~m}(6 \mathrm{ft})$. Evapotranspiration removed the moisture from these depths within several months (BN, 2005d). For further information, see the 2000 and 2001 WMMRs (BN, 2001, 2002b).

The U-3ax/bl cover system is very effective at removing soil moisture now that vegetation is established on the cover. Heavier-than-average precipitation in the fall and winter of 2004 infiltrated the cover and eventually percolated deeper than $152 \mathrm{~cm}(5 \mathrm{ft})$ at the East Nest B TDR array by March 2005. However, this percolating moisture was removed from the cover via evapotranspiration by September 2005 (BN, 2006d).

\subsubsection{Lysimeter Facilities}

In approximately 2000, a drainage lysimeter facility was constructed at the northwest corner of the Area 3 RWMS to gather additional data to help assess the performance of the future monolayer-ET covers planned for the Area 3 RWMS. Pertinent data are also obtained from the Area 5 weighing lysimeter facility at the Area 5 RWMS. Meteorological conditions at the Area 5 RWMS are very similar to the Area 3 RWMS. The Area 3 RWMS is higher in elevation, receives slightly more precipitation, and is a little cooler and windier than the Area 5 RWMS.

\section{Area 3 RWMS}

Figure 5 in Section 4.0, Monitoring Programs, shows the lysimeter facility location. The Area 3 RWMS facility consists of eight drainage lysimeters equipped with soil water content (TDR) and soil water potential (heat dissipation probe) sensors at eight depths ranging from 7.6 to $244 \mathrm{~cm}$ $(0.25$ to $8 \mathrm{ft})$. Drainage from the lysimeters provides an indirect measure of potential moisture movement below the landfill cover. Each lysimeter is approximately $3 \mathrm{~m}(10 \mathrm{ft})$ diameter and $2.4 \mathrm{~m}(8 \mathrm{ft})$ deep with a drain in the bottom. Lysimeters A and B are bare, lysimeters $\mathrm{C}$ and D were allowed to revegetate with invader species, and lysimeters $\mathrm{E}$ and $\mathrm{F}$ were revegetated with native species identical to the revegetation of the final cover at $\mathrm{U}-3 \mathrm{ax} / \mathrm{bl}$. Lysimeters $\mathrm{G}$ and $\mathrm{H}$ are reserved for future investigations, but handled similarly to $\mathrm{C}$ and $\mathrm{D}$. Lysimeters $\mathrm{B}, \mathrm{D}$, and $\mathrm{F}$ are irrigated with three times the average precipitation to simulate a shift to a wetter climate. Data from the U-3ax/bl automated waste cover monitoring system supplements the data from this lysimeter facility.

The lysimeters are effectively analogs for bare and vegetated landfill covers. Lysimeter $\mathrm{E}$ at the Area 3 RWMS is the analog for expected performance of the proposed final monolayer-ET landfill covers. Lysimeter F represents the performance of a cover with native vegetation in wetter climate conditions.

At the Area 3 RWMS, since 2000, the vegetated lysimeters have consistently been drier than the unvegetated lysimeters. Area 3 RWMS monitoring results after two consecutive wetter-thanaverage winters suggest that the evapotranspirative covers are very effective under current climate conditions, and provide significant protection under a potentially wetter climate. 
In 2004, a relatively wet year when the Area 3 RWMS received $263 \mathrm{~mm}$ (10.35 in.) of precipitation, drainage was observed at the bare soil lysimeter irrigated to receive a total of three times natural precipitation as a simulation of conditions under a wetter climate than we have today. The volume of water was equivalent to $12.3 \mathrm{~cm}(0.4 \mathrm{ft})$ of drainage $(\mathrm{BN}, 2005 \mathrm{~d})$. Three times the precipitation that fell in an unusually wet year on bare soil is an extreme scenario compared to the range of likely conditions projected over the next 1,000 years. No drainage was observed at the vegetated lysimeters.

In 2005, there were $219.1 \mathrm{~mm}$ (8.6 in.) of precipitation recorded at the Area 3 lysimeter facility. An additional $508.2 \mathrm{~mm}$ (20 in.) of irrigation water were applied to the irrigated lysimeters B, D, $\mathrm{F}$, and $\mathrm{G}$ to simulate a future wetter climate. Failure of an irrigation solenoid resulted in an unintended application of $507.9 \mathrm{~mm}$ (19.9 in.) of water between June 1 and June 15, 2005, to lysimeter F, the irrigated lysimeter vegetated with native species. Drainage occurred at all of the irrigated lysimeters; 23.7 percent of the precipitation and applied irrigation water drained from lysimeter F. No drainage occurred at the nonirrigated lysimeters. Moisture began to accumulate at the bottom of the unirrigated bare soil lysimeter A, but is slowly being removed by surface evaporation. Moisture also began to accumulate at the bottom of the unirrigated native vegetation lysimeter E, but most of this moisture was removed by evapotranspiration (BN, 2006d).

\section{Area 5 RWMS}

The Area 5 facility consists of two weighing lysimeters, one revegetated with native shrubs and the other bare.

Desotell et al. (2006) summarized and interpreted data collected since 1994 at the weighing lysimeter facility at the Area 5 RWMS in northern Frenchman Flat. The precision weighing lysimeters are $2 \mathrm{~m}(6 \mathrm{ft})$ deep and filled with native fill. One is vegetated and one is bare to simulate cover conditions at the landfills. Calibrated one-dimensional simulations of the lysimeter water balance using UNSAT-H generally agreed with field observations. Thirty-year model simulations conducted to evaluate long-term potential transport of radionuclides via the soil water migration pathway indicated that a 2-m- (6-ft)-thick closure cover with native vegetation will eliminate drainage through the cover and into the waste (Desotell et al., 2006).

Heavier-than-average precipitation occurred in October 2004 through February 2005 when temperatures were cool and evaporation rates lower. Higher than average infiltration over the wet winter resulted in observations of water accumulation at the bottom of the bare (unvegetated) weighing lysimeter at the Area 5 RWMS beginning in March 2005. Thirty-year numerical simulations with a unit gradient bottom boundary were used to estimate the amount of drainage that would have occurred if water could drain from this 2-m- (6-ft)-deep lysimeter. The simulations indicated an average of $1.0 \mathrm{~cm} /$ year would drain from the unvegetated lysimeter (BN, 2006d). This suggests that even without vegetation, a 2-m (6-ft) native alluvial cover provides significant protection from storm water infiltration.

\subsubsection{Conclusions}

A vadose zone monitoring system was installed at $U-3 b w$, about $340 \mathrm{~m}(1,115 \mathrm{ft})$ east of the southeast corner of the Area 3 RWMS (BN, 2005c) to evaluate the dynamic water balance of a typical undeveloped nuclear subsidence crater. Heat dissipation probes were installed in the floor of crater U-3bw to a depth of $4 \mathrm{~m}(13 \mathrm{ft})$ in December 1998. The floor of U-3bw also was 
instrumented with a 3-m (10-ft) meteorology tower and a neutron logging access tube. The U-3bw station was used to monitor depths of infiltration and moisture movement following rainfall, and the runoff due to the topography of the subsidence crater. The U-3bw station currently is not monitored because of monitoring budget priorities (BN, 2006d).

Neutron logging was used to evaluate if there was evidence of moisture movements at deeper levels in the Area 3 RWMS alluvium (BN, 2005c). Cased boreholes angled under the U-3ah/at and the $\mathrm{U}-3 \mathrm{ax} / \mathrm{bl}$ disposal cells provided access for neutron logging. The two characterization boreholes in the floor of the U-3bh crater were also cased and used for neutron probe access until they were abandoned to facilitate further development of the waste disposal cell. From 1998 through 2000, results of deep neutron logging conducted at cased boreholes angled under $\mathrm{U}-3 \mathrm{ah} / \mathrm{at}$, under U-3ax/bl, and vertical borings in the bottom of U-3bh indicate that water contents at depths below about $2 \mathrm{~m}(6 \mathrm{ft})$ generally do not change. A deeper wetting front at U-3bh was attributed to excessive dust control water applications during waste operations, and the water applications were curtailed (BN, 2001).

The soil moisture monitoring results at the Area 3 and 5 RWMSs confirm the effectiveness of monolayer soil covers in the current arid climate to prevent significant transmission of precipitation and runoff through the cover and down into the waste. 


\subsection{SATURATED ZONE}

Groundwater is an unlikely pathway for movement of potential contaminants from the Area 3 RWMS facility. The likelihood of Area 3 RWMS operations to release potential contaminants to groundwater and negatively impact groundwater quality is thought to be very low. Depth to groundwater in the uppermost aquifer is at least $488 \mathrm{~m}(1,600 \mathrm{ft})(\mathrm{BN}, 2005 \mathrm{~d})$. Conservative models of potential vertical groundwater movement, in the absence of preferential pathways, indicate that the potential for recharge in the next tens of thousands of years is extremely low (Shott et al., 2000). The active bulk LLW facility is not a RCRA-regulated hazardous waste treatment storage or disposal facility. Currently, groundwater monitoring is not required at the Area 3 RWMS.

Potential for future introduction of preferential pathways via development of groundwater wells is also thought to be low. The NTS is expected to be under active institutional control for 100 years. Site monuments warning of the presence of the Area 3 RWMS landfill and other surface indications may inhibit inadvertent intrusions for a period after institutional control is lost. The concern is that if someone were to inadvertently drill a well within the Area 3 RWMS, waste may be disturbed, and the drilling operation itself may facilitate movement of contaminants. Depending on the well construction methods, the new well itself could be a preferential pathway for the movement of water and contaminants through the vadose zone. However, Yucca flat is not likely to be an attractive location for future potable water supply development, particularly by a homesteader or a mining or agricultural business, because of existing groundwater contamination from historic underground tests and the depth to water. Future wells, if any, are more likely to be located closer to the mountain front recharge areas to reduce drilling costs and energy requirements to pump the water to ground surface.

The UGTA program and other NTS drilling operations have provided significant information about the regional aquifer system. Groundwater levels and quality at the NTS are monitored under USGS and DOE programs. Figure 21 shows USGS's monitoring well locations within about $5 \mathrm{~km}(3 \mathrm{mi})$ of the Area 3 RWMS. The nearest monitoring well is over $1 \mathrm{~km}(0.6 \mathrm{mi})$ from the Area 3 RWMS. The following sections provide an overview of groundwater characteristics in the vicinity of the Area 3 RWMS.

\subsection{Regional Hydrostratigraphy}

Hydrostratigraphic units are defined by characteristics affecting water flow and are a tool for flow modeling. Definition of hydrostratigraphic units has evolved gradually with the development of regional flow models. Blankennegal and Weir (1973) identified hydrogeologic units at the NTS according to their potential ability to transmit water. Winograd and Thordarson (1975) defined a hydrogeologic framework for regional groundwater flow. Laczniak et al. (1996) presented an updated summary of groundwater flow at the NTS, with focus on the UGTAs, the effects of past testing on groundwater flow, and further data needs for environmental restoration. The conceptual regional groundwater flow model is locally complicated by the impacts of historic underground testing. Test-induced pressure changes may have altered pre-test hydraulic gradients and probably have created local anomalies in vertical and lateral flow rates and flow directions. The consequences of such changes have not been fully determined (Laczniak et al., 1996). 


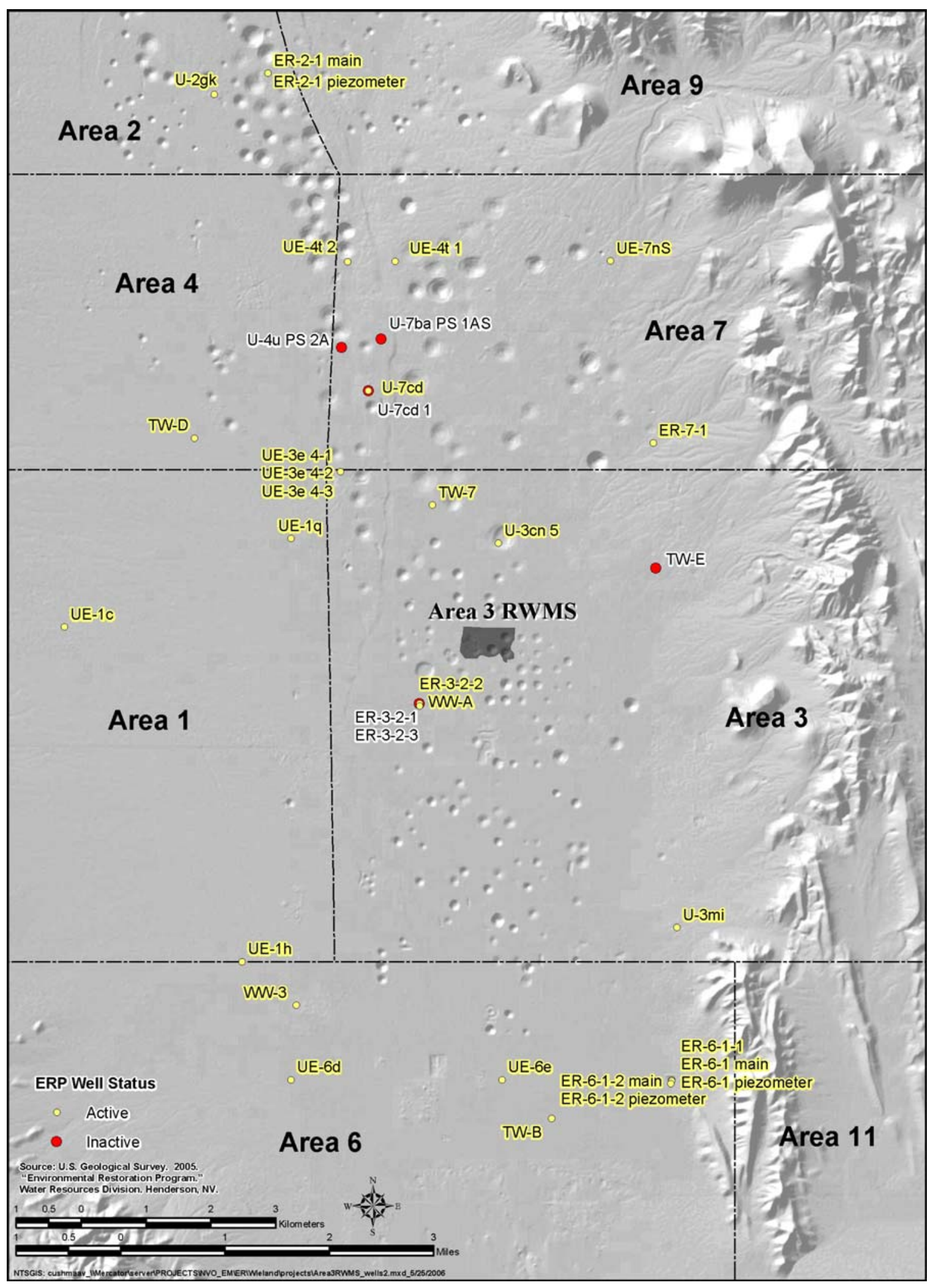

Figure 21

USGS Environmental Restoration Program Monitoring Well Locations 
The Area 3 RWMS is within the Yucca Flat/Climax Mine UGTA, CAU 97. Researchers developed a hydrostratigraphic model for the Yucca Flat and Climax Mine test areas between 1996 and 2005. The UGTA Project hydrogeologic modeling team defined aquifer and confining layer hydrostratigraphic units. IT Corporation published a regional model (IT, 1997, 1996a, 1996b). The final model is described in A Stratigraphic Model and Alternatives for the Groundwater Flow and Contaminant Transport Model of Corrective Action Unit 97: Yucca FlatClimax Mine, Lincoln and Nye Counties, Nevada (BN, 2006b).

Most of the rocks within the Yucca Flat region can be classified into eight hydrogeologic units. Each of these hydrogeologic units consists of one or more hydrostratigraphic units. The definition of these hydrostratigraphic units has evolved over the past decade. The 2004 NTSER (BN, 2005h) and the hydrostratigraphic model report (BN 2006b) contain detailed correlations relating hydrogeologic units to hydrostratigraphic units. Figure 12 in Section 5.0 shows a simplified cross-section of the Area 3 RWMS. Figure 22 shows the hydrostratigraphy in more detail, with major structures. This West-East cross-section of the vicinity of the Area 3 RWMS cutting through U-3ax extracted from the hydrostratigraphy model for CAU 97 also shows the major faults projected through the alluvium to ground surface. The east edge of the Area 3 RWMS facility is thought to overlie the Area 3 fault.

In Yucca Flat, typically unconsolidated to partially consolidated alluvium, colluvium, and thin limited-extent basalt flows compose the Alluvial Aquifer unit. The volcanic rocks are categorized into four hydrogeologic units based on lithologic properties, degree of fracturing, and secondary mineral alteration. Altered and typically zeolotized rocks comprise the Tuff Confining Unit. The unaltered volcanic rocks form the Welded Tuff Aquifer, Vitric Tuff Aquifer, and Lava Flow Aquifer units. A clastic confining unit is present in the west part of Yucca Flat, primarily west of the Topgallant Fault. The Tuff Confining Unit directly overlies the two hydrogeologic units that comprise the Carbonate Aquifer in the area of the Area 3 RWMS (BN, 2005h).

BN (2005h) summarized general hydraulic characteristics of NTS rocks by hydrogeologic unit. Table 13 presents a qualitative summary. The zeolitized nonwelded ash-flow tuffs and bedded tuffs tended to have the lowest transmissivities. The interconnectivity of the pores is poor. These tuffs are relatively incompetent and do not tend to support open fractures. Secondary alteration increases impermeability. The zeolitized tuffs are considered confining units. The moderately to densely welded ash-flow tuffs (Welded Tuff Aquifer), rhyolitic lava flows (Lava Flow Aquifer), and carbonate rocks (carbonate aquifer) are the most transmissive. Groundwater flow through these aquifer units is thought to be largely through interconnected fractures (rather than interstitial pore space).

In Yucca Flat, the welded tuff aquifer is characterized by high fracture permeability. Measurements of saturated hydraulic conductivity in seven welded tuff samples ranged from 0.09 to $1.71 \mathrm{~m} /$ day ( 0.3 to $5.61 \mathrm{ft} /$ day) (Rehfeldt et al., 1995, as cited in Shott et al., 2000). The tuff confining unit is a bedded nonwelded tuff with alteration to zeolite minerals. Measurements of saturated hydraulic conductivity in 34 zeolitized tuff samples ranged from $2 \times 10^{-6}$ to $0.02 \mathrm{~m} /$ day $\left(7 \times 10^{-6}\right.$ to $0.07 \mathrm{ft} /$ day) (Winograd and Thordarson, 1975). The water table at the vicinity of the Area 3 RWMS is in volcanic units below the alluvium. 


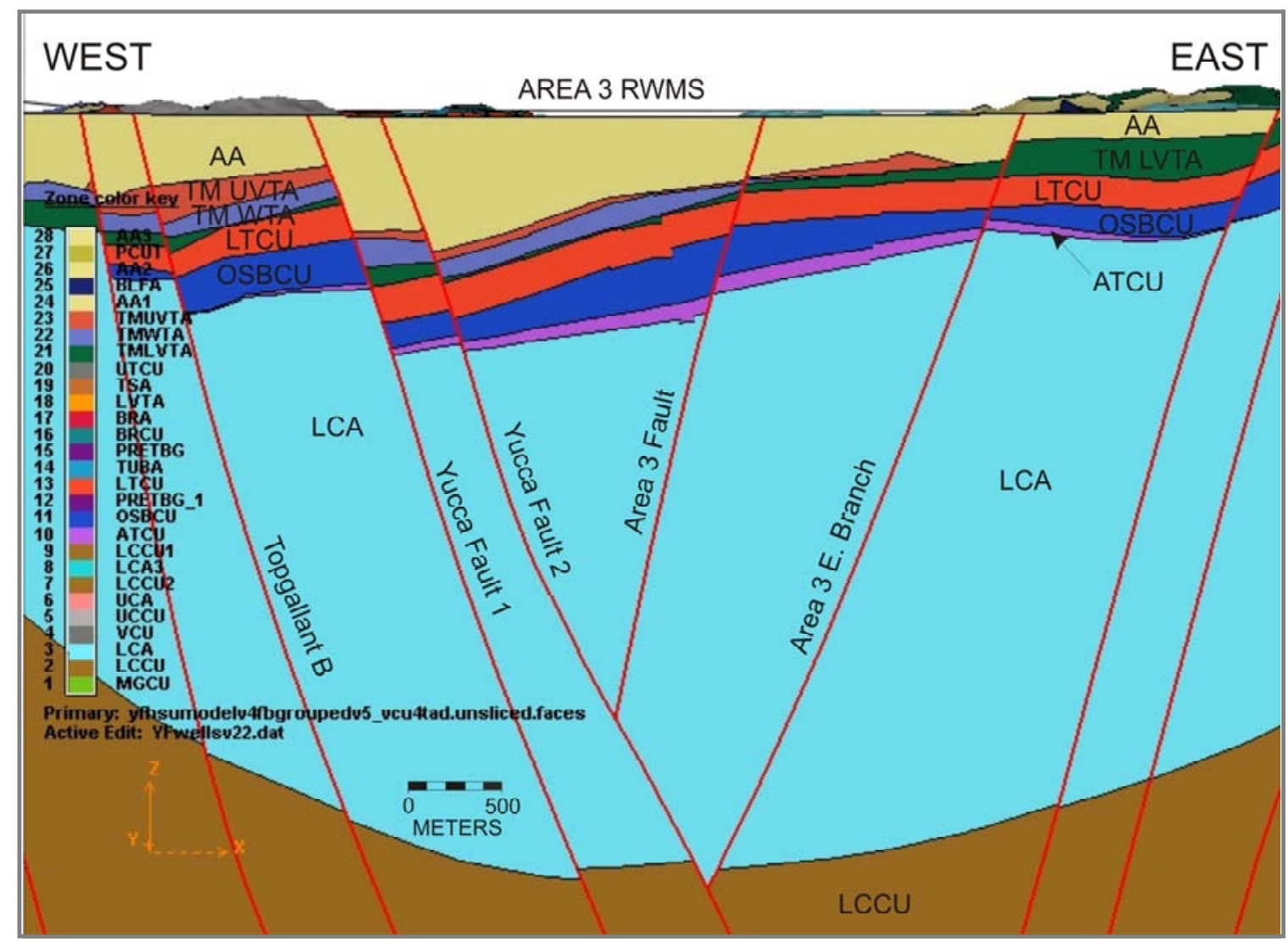

Figure 22

West-East Cross-Section of Area 3 RWMS Showing Hydrostratigraphic Units and Faults

Table 13

Summary of Hydrologic Properties for Hydrogeologic Units in Yucca Flat at the NTS

\begin{tabular}{|l|l|l|}
\hline \multicolumn{1}{|c|}{ Hydrogeologic Unit } & \multicolumn{1}{|c|}{ Fracture Density } & $\begin{array}{l}\text { Relative Hydraulic } \\
\text { Conductivity }\end{array}$ \\
\hline Alluvial Aquifer & Very low & Moderate to very high \\
\hline Vitric Tuff Aquifer & Low & Low to moderate \\
\hline Welded Tuff Aquifer & Moderate to high & Moderate to very high \\
\hline Tuff Confining Unit & Low & Very low \\
\hline Granite Confining Unit & Low to moderate & Very low \\
\hline Carbonate Aquifer & Low to high & Low to very high \\
\hline Clastic Confining Unit & $\begin{array}{l}\text { Moderate (fractures tend } \\
\text { to be sealed by secondary } \\
\text { minerals) }\end{array}$ & Very low to low. \\
\hline
\end{tabular}

Source:

Adapted from Bechtel Nevada, 2005. Nevada Test Site Environmental Report 2004.

DOE/NV/11718--080. Las Vegas, Nevada, October 2005. 
The Lower Carbonate Aquifer (LCA) is the primary regional aquifer. The LCA is highly heterogeneous laterally and vertically across Yucca Flat. Aquifer testing has been used to better define characteristics of the LCA over larger scales within Yucca Flat. Stoller-Navarro Joint Venture conducted hydraulic testing at several wells located in Area 6 and 7 near the edges of the CAU 97 boundary. Ten-day single-well constant rate pumping tests at ER-7-1 and ER-6-2 and a 90-day multiple-well test at well cluster ER-6-1 provided data on the spatial variability of hydraulic properties related to local fracturing and basin-scale faulting across Yucca Flat (Bhark and Ruskauff, 2005). Detailed results of each Yucca Flat pump tests are presented in individual reports (e.g., Stoller-Navarro, 2005). Data documentation packages with detailed flow and transport information will be prepared for the hydrologic models under development for CAU 97 Yucca Flat-Climax Mine (BN, 2006b).

\subsection{Groundwater Levels and Flow}

Yucca Flat has a multiple aquifer system with limited communication between aquifers. Interpretation of measured groundwater levels must take into account which levels of the system are tapped by the wells. Confining units and faults complicate groundwater recharge and flow through the system. Currently, the gradient is fairly flat and stable, but significant fluctuations occurred during underground nuclear testing, which could have locally affected distribution of contaminants from those tests. The rate of regional groundwater flow is slow; therefore, the time for groundwater in vicinity of the Area 3 RWMS to migrate to off-NTS springs or water supply wells is very long. Further details follow.

The USGS monitors water levels at a network of wells on and off of the NTS in cooperation with the DOE. There are currently no water-level monitoring wells very close to the Area 3 RWMS (Figure 21), but groundwater levels at the Area 3 RWMS can be inferred from the regional data. BN (2005d) estimated the thickness of the unsaturated zone at the Area 3 RWMS to be approximately $488 \mathrm{~m}(1,600 \mathrm{ft})$. Other sources suggest the water table is even deeper. BN (1998b) and Shott et al. (2000) estimated depth to water at the Area 3 RWMS to be $492 \mathrm{~m}$ (1,614 ft). The water table is thought to be within a tuff aquifer unit under the western part of the Area 3 RWMS and in a tuff confining unit under the eastern part of the RWMS (see Figure 12 in Section 5.0). Depth to the main regional carbonate aquifer is greater.

The groundwater gradient in this region of Yucca Flat is fairly flat. Water levels reflective of the LCA indicate the groundwater gradient is less than $0.2 \mathrm{~m} / \mathrm{km}(1 \mathrm{ft} / \mathrm{mi})$ between Yucca and Frenchman Flats down to the discharge area, outside of the NTS, in Ash Meadows (Shott et al., 2000).

Table 14 shows depth-to-water measurements collected December 8, 2005, at several wells surrounding the Area 3 RWMS region. In this part of Yucca Flat, a significant aquitard separates the alluvial and tuff aquifer units from the regional carbonate aquifer. Although these wells are completed to different depths, have different screened or open intervals, draw from different aquifer units, are subject to a variety of local pumping and test activities that could affect water levels, and are located miles apart within the basin, the order of magnitude of these depth-towater measurements are quite similar. 
Table 14

Depth to Groundwater at Several Wells in Area 3 of the NTS

\begin{tabular}{|l|c|c|c|c|l|}
\hline \multicolumn{1}{|c|}{ Well } & $\begin{array}{c}\text { Water Level } \\
\text { Measurement } \\
\text { Date }\end{array}$ & $\begin{array}{c}\text { Land-Surface } \\
\text { Altitude } \\
\text { (ft AMSL) }\end{array}$ & $\begin{array}{c}\text { Water Level } \\
\text { Below Land } \\
\text { Surface } \\
\text { (ft) }\end{array}$ & $\begin{array}{c}\text { Water } \\
\text { Elevation } \\
\text { (ft AMSL)* }\end{array}$ & \multicolumn{1}{|c|}{$\begin{array}{c}\text { Primary } \\
\text { Aquifer }\end{array}$} \\
\hline U-3mi & $12 / 08 / 2005$ & 4005.77 & 1557.79 & 2447.98 & Volcanic rocks \\
\hline U-3cn 5 & $12 / 08 / 2005$ & 4009.22 & 1620.15 & 2389.07 & Carbonate rocks \\
\hline WW-A & $12 / 08 / 2005$ & 4006.42 & 1600.40 & 2406.02 & Valley fill deposits \\
\hline TW-7 & $12 / 08 / 2005$ & 4057.76 & 1644.61 & 2413.15 & Volcanic rocks \\
\hline $\begin{array}{c}\text { ER 3-2-2 } \\
\text { (middle) }\end{array}$ & $12 / 08 / 2005$ & 4010.09 & 1604.05 & 2406.04 & Valley fill deposits \\
\hline
\end{tabular}

* Water elevation calculated from land surface elevation and water level depth below land surface data

Source:

U.S. Geological Survey, USGS/USDOE Cooperative Studies Program, Nevada Test Site, Area 3 well data web page. Data accessed on March 9, 2006 http://nevada.usgs.gov/doe\%5Fnv/ntsarea3.cfm

Joseph Fenelon (2005) analyzed Yucca Flat water level data collected between 1951 and 2003 and identified trends. He concluded that some minor natural variations in water levels may result from variations in recharge. Barometric pressure changes and earth tides also cause water level fluctuations throughout Yucca Flat. The impact is largest in wells open to confined aquifers. The combined response is less than $30 \mathrm{~cm}(1 \mathrm{ft})$. Other (minor) potential causes of water level fluctuation in Yucca Flat include establishing equilibrium following well construction or development, pumping or hydraulic testing, and land subsidence (Fenelon, 2005).

Fenelon (2005) concluded that past anthropogenic water-level fluctuations were primarily caused by water withdrawals and nuclear testing. Nuclear tests below or near the water table affected water levels through seismic responses, pore-water pressurization, pore-water depressurization and cavity infilling. Only a few wells are affected by water withdrawals, but approximately 35 percent of the measured water levels in Yucca Flat were affected by nuclear tests, in a database of about 4,000 measurements taken from 1951 to 2003 (Fenelon, 2005). The impacts of nuclear tests on water levels typically dissipated over a few years.

Fenelon (2005) noted that some groundwater mounding attributed to past underground nuclear testing persists in Areas 4 and 9 of the NTS, in the Northern part of Yucca Flat, between the Carpetbag and Yucca faults. In areas where the valley fill deposits are at the water table, groundwater mounding after a nuclear test may be because of decreases in the porosity and permeability of the saturated deposits. In other areas, high-pressure zones occur in the tuff confining unit. The boreholes observed to have had the largest upward movements in water levels tended to be in the volcanics. Vertical water level differences in the carbonate aquifer and valley fill aquifer were typically small in comparison.

It is unknown if there was significant water level mounding after nuclear testing within the area that was later developed as the Area 3 RWMS, but Fenelon noted that there was a maximum change of $107 \mathrm{~m}(350 \mathrm{ft})$ over a 14-year period at monitoring well U-3cn PS 2. The U-3cn test site is only $1.4 \mathrm{~km}(0.9 \mathrm{mi})$ north of the Area 3 RWMS boundary. For tests within or near the 
water table, large water table fluctuations may transport contaminants from the test cavity up above the current water table level. In the Area 3 RWMS part of Yucca Flat, any temporary changes in the water levels from the 1960s tests are thought to have equilibrated.

Laczniak et al. (1996) summarized regional groundwater flow information. Both Yucca flat and Frenchman flat are in the Ash Meadows groundwater sub-basin which covers an area of about $10,360 \mathrm{~km}^{2}\left(4,000 \mathrm{mi}^{2}\right)$, including the eastern half of the NTS. The regional carbonate aquifer is the main aquifer in this sub-basin. Precipitation recharges at the mountain fronts. Regional data indicate that the groundwater slowly moves from the recharge areas toward Frenchman Flat, and then southwest, primarily through the carbonate aquifer. Figure 23 shows the regional groundwater flow pattern for the NTS. The Ash Meadows sub-basin discharges at a ten-mile-long line of springs that generally coincides with the trace of a buried fault, in Ash Meadows, Nevada. The springs are about $64.3 \mathrm{~km}$ (40 mi) downgradient of the Yucca Flat test area (Laczniak et al., 1996).

Estimates of groundwater flow rates vary significantly across Yucca Flat. Porosity, fracturing, head, layering, and faults can affect local flow. Folds and faults compartmentalize the flow system and restrict regional groundwater flow in areas where aquifers juxtapose confining units (Fenelon, 2005). Fractures along some fault zones facilitate leakage across the aquitard. Bhark and Ruskauff (2005) reported that, based on analysis of pump test data from Yucca Flat, on a basin scale, "the data indicate a fracture or high-permeability strip-dominated flow regime created by fault-related features." The north-south-trending faults in Yucca Flat appear to act as both east-west flow barriers and north-south high-permeability conduits. On a smaller, local well scale (tens of meters), the local flow geometry within fault blocks appears to control response (Bhark and Ruskauff, 2005).

Various studies using groundwater age estimates, flow models, and geochemical models agree that the rate of groundwater movement from Yucca Flat and through the rest of the Ash Meadows sub-basin is very slow. The PA/CA summarizes some of the early studies. The complexity of the hydrostratigraphy is documented in the hydrostratigraphic model for CAU 97 (BN, 2006b), which develops five alternative interpretations for major features for use in future regional flow model efforts for the UGTA program.

Groundwater is thought to leave the basin only through the LCA (e.g., Laczniac, 1996). Flow of water into the LCA is constrained by confining units bounding the basin and the leakage through the tuff aquitard from the saturated aquifer units above. Winograd and Thordarson (1975) estimated leakage rates through the tuff confining unit of 0.00015 to $0.061 \mathrm{~m} / \mathrm{yr}(0.0005$ to $0.2 \mathrm{ft} /$ day). The leakage estimates do not take into account fractures (Shott et al., 2000). Estimated total outflow from beneath Yucca Flat is estimated to be $430,000 \mathrm{~m}^{3} / \mathrm{yr}$ (350 acre-ft/yr) (Winograd and Thordarson, 1975) or less than 3 percent of the estimated total outflow at the Ash Meadows discharge area. Yucca Flat outflows are small (despite fractures and good transmissivities) because inflows to Yucca Flat are limited by confining units bounding the basin (Laczniak et al., 1996) and the low head. 


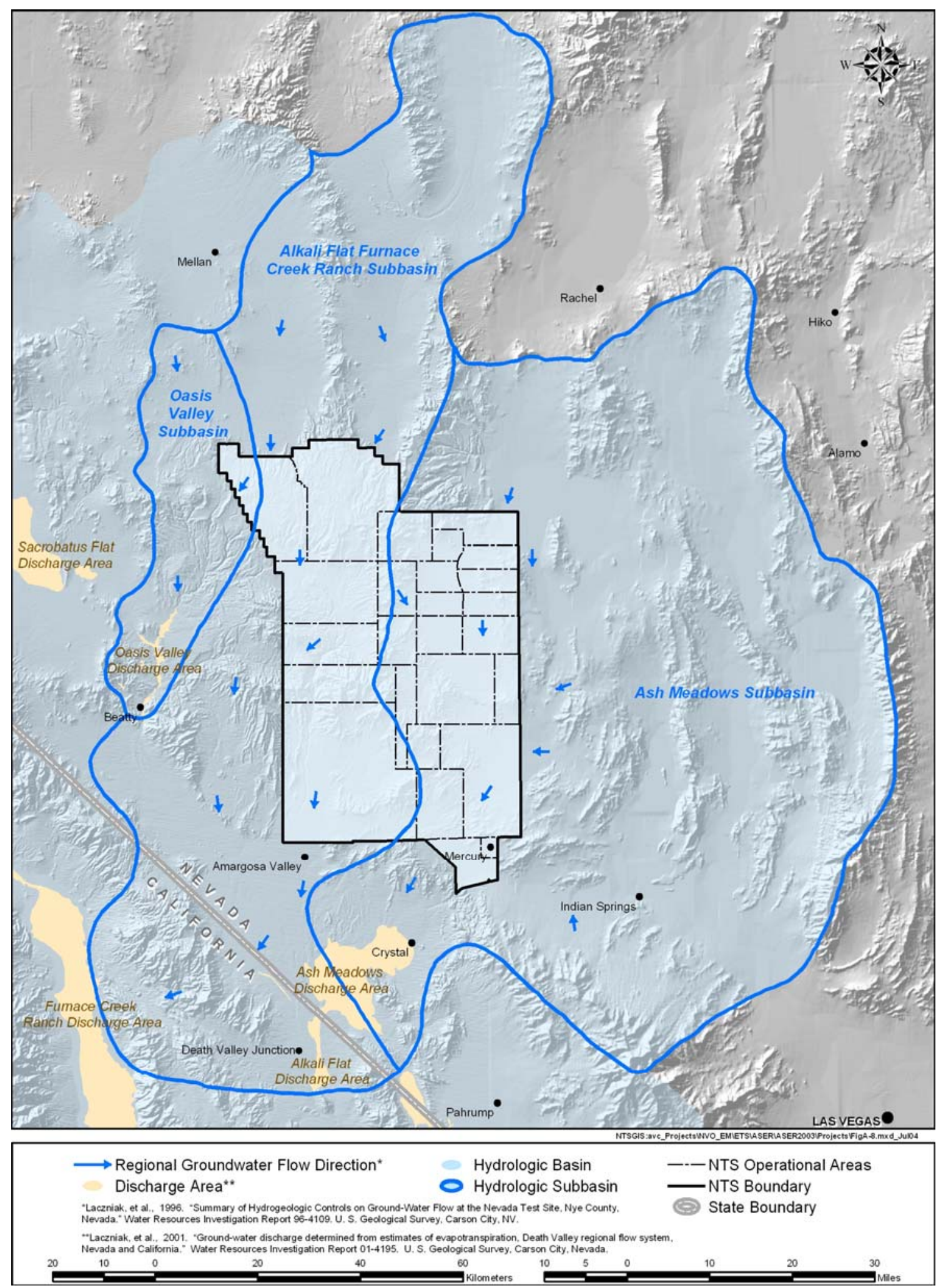

Figure 23

Regional Groundwater Flow and Discharge Areas 
Groundwater pumping from the Ash Meadows sub-basin includes scattered supply wells at the NTS and a few off-site domestic wells. Regional groundwater gradients and flow rates are unlikely to be significantly impacted by current groundwater withdrawal patterns within Yucca Flat.

Recently, Stoller-Navarro (2006) used geochemical and isotopic data to evaluate regional groundwater movement. The researchers reviewed available data from central databases, as well as unpublished and published data from Desert Research Institute (DRI), LANL, and USGS files and identified representative data meeting quality criteria. Using geochemical characteristics, the researchers evaluated inflow to the Yucca Flat basin versus mountain front recharge. Using the PHREEQC model code, they studied rock/water interactions, modeled mixing scenarios, and studied trends along three major flow paths. Using the Netpath model code, they estimated travel velocities between wells along the three major flow paths. In the north part of Yucca Basin, the models yielded estimated linear velocities of 1.3 to $1.9 \mathrm{~m}$ (4.3 to $6.2 \mathrm{ft})$ per year. In the southeast part of the basin, between wells ER-3-1 and WW-C, the modeled transit times ranged from 4.3 to $13 \mathrm{~m} \mathrm{(14.1} \mathrm{to} 43 \mathrm{ft}$ ) per year. Stoller-Navarro (2006) attributed the differences to the distribution of the Lower Clastic Confining Unit (LCCU), which is not present in the southeast part of the basin.

Because the Area 3 RWMS is in the middle of the basin in an area with significant LCCU thickness, linear flow velocity is likely to be more similar to the north basin estimates than to the southeast basin estimates.

The geochemical and isotopic data supported hydrogeologic interpretations of low leakage rates from the upper aquifers through the tuff confining unit to the regional carbonate aquifer. StollerNavarro (2006) observed potential evidence of leakage in west central Yucca Flat between overlying volcanic units and the carbonate hydrostratigraphic units. The researchers noted that the small groundwater flux through the LCA in Yucca Flat may be attributable to the small inflow of groundwater into the basin rather than the hydraulic conductivity of the fractured unit.

Stoller-Navarro (2006) provided age estimates from dissolved carbon-14 $\left({ }^{14} \mathrm{C}\right)$ data. Groundwater age estimates for several samples collected along the east flow path, the path closest to the Area 3 RWMS, ranged from 1,000 to 20,000 years, but none of the well sample locations were in Area 3.

\subsection{Groundwater Chemistry}

Schoff and Moore (1964) described the chemistry of groundwater at the NTS, related water chemistry types to rock type, and inferred evidence of water movement from distributions of major ions and total dissolved solids on a regional basis.

The CAIP for CAU 97 (DOE, 2000b) presents more detailed data specific to Yucca Flat. Yucca Flat groundwaters vary from a mixed calcium-magnesium-sodium water type to a predominately sodium type. Bicarbonate is the predominant anion. Sulfate ranges from 5 to 20 percent and chloride ranges from 5 to 10 percent of the total anionic milliequivalents. Higher sulfate concentrations correlate with higher levels of chloride. The report identifies four water type 
groups based on cation composition within the Yucca Flat data and relates them to aquifer rock types and locations with respect to flow paths. Water from the wells nearest to the Area 3 RWMS appears to be within a mixed hydrochemical facies.

Stoller-Navarro (2006) compiled and evaluated available geochemical and isotopic data from many sources and identified representative data. The researchers used the data to evaluate groundwater movement through and downgradient of the CAU 97 UGTA project.

\subsection{Groundwater Quality}

Yucca Flat was the site of 80 atmospheric and 659 underground nuclear tests. Within just $400 \mathrm{~m}$ $(1,312 \mathrm{ft})$ of the Area 3 RWMS boundary, the United States conducted 60 nuclear weapons tests between 1952 and 1972 (BN, 2005d). Groundwater quality at the NTS has been locally impacted by past underground testing. Some of the historic nuclear tests at the NTS occurred below or near the pre-test water table. The USGS reports that at least 144 and as many as 236 tests at Yucca Flat and Frenchman Flat were detonated at depths sufficient to have directly introduced contaminants to groundwater (Laczniak et al., 1996). Groundwater quality with respect to radionuclides has been assessed and monitored in the Yucca Flat region through several programs and projects since at least the mid-1970s. The impacted groundwater zones are generally highly localized near the test sources.

All of the nuclear tests within the Area 3 RWMS facility boundary were in the vadose zone above the groundwater table. Although there are no site-specific groundwater quality data from the Area 3 RWMS, there are regional data. Appendix B contains water quality data for well U-1EQ northwest of the Area 3 RWMS and USGS well WWA southwest of the site.

The HRMP and the Radionuclide Migration Project have conducted investigations in the immediate vicinity of many nuclear test locations. The HRMP is a very broad water supply management program sponsored by DOE with participation from BN, DRI, EPA, LANL, Lawrence Livermore National Laboratory (LLNL), and the USGS. Objectives pertinent to the Yucca Flat/Climax Mine corrective action investigation include determining the behavior of radionuclides in the NTS underground environment, the impacts of testing on the geology and hydrology, and factors controlling transport of radionuclides by groundwater. The pertinent investigations have been focused on the near-field environment. Radionuclides, primarily tritium, were detected in several emplacement and exploratory boreholes in Yucca Flat (DOE, 2000b).

The nearest HRMP study area to the Area 3 RWMS is in the vicinity of the Bilby test at U-3cn, approximately $1.4 \mathrm{~km}(0.9 \mathrm{mi})$ north of the Area $3 \mathrm{RWMS}$ boundary. The test at U-3cn was detonated below the water table in 1963 and, based on yield, was one of the largest underground tests conducted in Yucca Flat (DOE, 2000b).

LLNL (Rose et al., 2003) summarizes work to define the extent of radionuclide contamination of NTS groundwater from underground nuclear testing. The working point of the Bilby test was within the tuff confining unit just above the LCA. Borehole U-3cn PS\#2 was drilled within the collapse chimney soon after the test and originally completed in the test cavity, but is now open at new perforations made between 512 and $527 \mathrm{~m}$ (1,680 and 1,729 ft) depth. Groundwater samples have been collected sporadically at this well since 1964. A satellite hole near the Bilby test, U-3cn \#5, was completed in the Paleozoic carbonate rocks and has also been periodically 
monitored since the mid-1960s. Based on examination of tritium data from samples collected from these wells in 1997 and 2001, Rose et al. (2003) concluded that little or no contamination is moving downward from the Bilby test cavity to the underlying carbonate aquifer. The CAU 97 CAIP (DOE, 2000b) summarizes historic radionuclide groundwater quality data for wells $\mathrm{U}-3 \mathrm{cn}$ PS2 and U-3en \#5.

The Bilby test contamination source is unlikely to impact groundwater quality at the Area 3 RWMS any time soon because this contamination source is almost one mile upgradient of the Area 3 RWMS, and little of the radionuclide contamination has apparently reached the regional carbonate aquifer yet, where the primary regional groundwater movement occurs. Estimated groundwater flow rates at the NTS are highly variable, but generally low in the tuff confining unit and highest in the carbonate aquifer (see Section 13.2). Zeolites in the ash flow tuff may also impede movement of radionuclides from the source area.

In 1972, DOE initiated the Long-Term Hydrological Monitoring Program. The EPA operated the program under an interagency agreement. In about 1990, DOE's M\&O contractor (REECo) took over the program from the EPA. The program includes routine radiological monitoring of a network of groundwater wells on the NTS and from wells and springs off site of the NTS. The program was replaced by the comprehensive RREMP by 1999 . BN currently implements the RREMP for the DOE. Results are published in the NTS ASER (e.g., BN, 2005d).

The list of analytes and the frequency of sampling have varied over time, but generally there has been at least one analysis per year from each location for gamma-emitting radionuclides and tritium (DOE, 2000b).

Much of the radionuclide residuals left after underground testing are bound up in puddle glass in the cavity and are relatively immobile. Tritium is one of the most mobile and abundant radionuclides. DOE (2000b) summarized tritium data for Yucca Flat and off-site locations collected between 1989 and 1998. They concluded that tritium was not consistently detected in groundwater from any of the off-NTS sampling locations. Tritium has been detected in groundwater from several wells in Yucca Flat, including Water Well A, which is located several miles southwest of the Area 3 RWMS (see Figure 21, USGS Environmental Restoration Program Monitoring Well Locations). The annual average tritium in samples collected from Water Well A in 1994 was $170 \mathrm{pCi} / \mathrm{L}$ (DOE, 2000b).

Groundwater across the NTS is tested biennially for gross alpha, gross beta, gamma spectroscopy, and plutonium under the RREMP (BN, 2003b). Groundwater is also monitored for ${ }^{14} \mathrm{C},{ }^{90} \mathrm{Sr}$, technetium-99, and tritium (BN, 2005h). None of the regional monitoring wells are close to the Area 3 RWMS. BEIDMS contains much of the available groundwater quality data for the NTS. Appendix B contains water quality data for two wells in Yucca Flat closest to the Area 3 RWMS.

There is no facility-specific groundwater monitoring at the Area 3 RWMS. The PA and CA (Shott et al., 2000) indicate that groundwater is not a likely pathway for transport of contaminants from the landfill cells and that recharge is unlikely to occur at the Area 3 RWMS during the 1,000 -year compliance period. Furthermore, there is no regulatory groundwater monitoring requirement for LLW disposal cells. 
There are RCRA groundwater monitoring requirements for hazardous waste facilities, including LLMW disposal sites; however, NDEP approved an exemption from Title 40 CFR 265.310 (CFR, 1999) groundwater monitoring for U-3ax/bl through approval of RCRA Permit HW0021 (NDEP, 2005). The RCRA permit application contained a detailed monitoring waiver petition in accordance with Title 40 CFR 265.90 (c). 


\subsection{CLOSURE PLANNING}

\subsection{Regulatory Context}

The active LLW disposal cells (U-3ah/at and U-3bh) do not accept LLMW; therefore, they are not hazardous waste facilities regulated under RCRA. The active cells also do not accept TRU waste; therefore, they are not subject to Title 40 CFR 191 (CFR, 1996b). LLW with no other hazardous component is self-regulated by the DOE. The current Order governing management of radioactive waste is DOE Order 435.1 (DOE, 2001c). Associated with DOE Order 435.1 are a manual (DOE M 435.1-1 [2001a]) and a guidance document (DOE G 435.1-1 [1999a]) which provide the standards and requirements for closure of LLW disposal cells and for monitoring. The results of the PA and CA are used to determine some of the details of the monitoring plan, including media, locations, radionuclides and other substances to be monitored. A brief summary of the pertinent regulatory requirements is in the ICMP (BN, 2005c).

\subsection{Supporting Documents}

The DOE M 435.1-1 (2001a) and DOE G 435.1-1 (associated with DOE Order 435.1 [2001c]) require development of preliminary closure and monitoring plans to be submitted with the PA and CA. The DAS also requires development of these plans. In 2001, NNSA/NSO's contractor developed the ICMP (BN, 2005c) for closing and monitoring both the Area 3 and the Area 5 RWMSs and, in June 2005, published a revision which had limited distribution. Another update is anticipated later in FY 2006. The ICMP defines the approach and schedule for closure. The preliminary closure and monitoring plans were integrated for efficiency because much of the information to be included in the plans is the same. The cover design and monitoring plan must ensure performance of the cover meets DOE performance standards.

\subsection{Work in Progress}

The existing body of site characterization data provides ample basis for closure planning at the Area 3 RWMS. There are ongoing monitoring programs and studies that will provide additional characterization data, which will primarily support compliance and performance assessments. The 1995 WMMR and the 1995 NTSER will be published in calendar year 2006. Neptune and Co. expects to publish their latest biotic characterization findings this year. Several key characterization reports for the Area 3 RWMS, which were originally prepared by NNSA/NSO contractors for DOE in the 1990s and had very limited distribution, are expected to be formally published by the end of FY 2006. The reports are being reviewed and revised if necessary to bring them up to current DOE publication standards and security classification guidelines.

The ICMP is updated, as needed, in accordance with requirements of the DASs for the RWMSs. The ICMP is a preliminary plan that will serve as a reference document for the development of site-specific closure and post-closure monitoring plans when the facility is closed. 


\subsection{Closure Schedule}

Final closure of the U-3 ah/at and U-3bh disposal cells at the Area 3 RWMS is currently scheduled to be completed in FY 2008. Draft criteria have been developed for the conceptual design of the closure cover.

DOE ordered that the Area 3 RWMS be placed on inactive status as of July 1, 2006. The waste is covered by an operational cover. The Area 3 RWMS has significant remaining capacity and may be reactivated by DOE, if needed, prior to final closure. 


\subsection{POST-CLOSURE MONITORING}

Most of the current monitoring program (Section 4.0) will continue after closure during the period of active institutional control. However, data needs will be evaluated periodically through the PA and CA maintenance process (BN, 2002c); therefore, the composition and frequency of monitoring may change.

The automated vadose zone monitoring system has provided several years of cover moisture conditions data over a broad range of precipitation and vegetation irrigation conditions. Several on-site lysimeters are designed to replicate cover conditions and provide comparable data and are suitable surrogates for monitoring the covers directly. Consequently, to minimize penetrations in the final cover, direct monitoring of the moisture conditions in the future U-3bh and U-3ah/at final landfill covers is not planned or necessary. 
This Page Intentionally Left Blank 


\subsection{CONCLUSIONS AND RECOMMENDATIONS}

Over the past several decades, significant site characterization assessments, environmental monitoring, and contaminant transport modeling have been performed pertinent to the Area 3 RWMS area of Yucca Flat. These data have been used for assessment of Area 3 RWMS facility performance with respect to containment objectives and requirements specified in DOE M 435.1-1 (2001a). The potential pathways for contaminant transport generally have been well defined. A few potential preferred pathways in the uppermost part of the vadose zone have been identified within the Area 3 RWMS: lineaments from past nuclear tests and unplugged inactive borings from past testing. These near-surface potential preferential pathways are not believed to affect the ability of the facility to meet DOE performance criteria. The nature of the waste; containers; the arid climate; physical and chemical properties of the thick, dry vadose zone; the depth to groundwater; and other factors mitigate potential transport of contaminants. The site setting, waste characteristics, proposed cover characteristics, flood mitigation features, and environmental monitoring program help ensure potential exposures of the public and employees are ALARA and meet DOE facility performance objectives.

The data quality objectives for the inputs required to define transport pathways and processes and perform the PA and CA also effectively address characterization data requirements for development of closure plans. Adequate characterization data are available to design the final cover, and develop the closure plan and post-closure monitoring plan. The closure and postclosure monitoring plans may be combined for efficiency.

The nature of the waste is adequately defined to safely close the site without further assessment. Both active cells operated after the implementation of computer database waste tracking systems. The current waste tracking systems are very detailed and accurate.

Much of the radioactive inventory is relatively immobile as activated surfaces of bulk waste or solids sealed within containers. Volatile and soluble nuclides (i.e., radon and tritium, respectively) are the most likely to be released via diffusion and evapotranspiration as cracks in the landfill covers develop and subsidence and erosion of the landfill covers ceases after active maintenance and institutional control of the facility. Reworking of landfill cover soil by burrowing insects and mammals may enhance movement of particulate radionuclides and enhance infiltration of storm water runoff. However, the arid climate will continue to be a significant control on the volumes of water available to pond upon, infiltrate, and percolate through the landfill covers, through the waste, and into surrounding alluvium.

The existing monitoring programs appear to be adequate to assess any potential future releases from the Area 3 RWMS waste disposal cells. These programs should continue to be reevaluated as needed under the PA in accordance with the PA/CA maintenance plan.

Experience gained from construction and management of the U-3ax/bl final closure cover can be applied to closure plans for the active cells. The lysimeter monitoring program is an effective surrogate for direct monitoring of moisture movement through the landfill cell covers.

The principle recommendations are to continue with site monitoring and reporting activities and to proceed with development of the Closure Plan for the Area 3 RWMS. 
This Page Intentionally Left Blank 
ARL/SORD. See Air Resources Laboratory Special Operations and Research Division.

Air Resources Laboratory Special Operations and Research Division, 2006. Extracted on March 23, 2006, from http://www.sord.nv.doe.gov/arlsord-1.htm.

— 2002. November 19, 2002, Climate Summary. Extracted on March 23, 2006, from http://www.sord.nv.doe.gov/home_climate_MEDA.htm.

Allred, D. M., D. M. Beck, and C. D. Jorgensen, 1963. "Biotic Communities of the Nevada Test Site.” Brigham Young University Science Bulletin, Biological Series 2(2), No. 2.

Angerer, J. P., W. K. Ostler, W. D. Gabbert, and B. W. Schultz, 1994. Secondary Succession of Disturbed Sites at Yucca Mountain, Nevada. EG\&G Energy Measurements, Inc., Santa Barbara, CA. December 1994

Barker, L., 1997. Alternative Evaluation Study: Methods to Mitigate/Accommodate Subsidence for the Radioactive Waste Management Sites at the Nevada Test Site, Nye County, Nevada, with Special Focus on Disposal Unit U-3ax/bl. Bechtel Nevada, Las Vegas, NV. September, 1997.

Beatley, J. C., 1969. "Biomass of Desert Winter Annual Plant Populations in Southern Nevada." Oikos, 20:261-274.

Bechtel Nevada, 2006a. Fiscal Year 2005 Annual Summary Report for the Area 3 and Area 5 Radioactive Waste Management Sites at the Nevada Test Site, Nye County, Nevada. Las Vegas, NV. January 24, 2006. Unbound letter report. 10 pages.

—, 2006b. A Hydrostratigraphic Model and Alternatives for the Groundwater Flow and Contaminant Transport Model of Corrective Action Unit 97: Yucca Flat-Climax Mine, Lincoln and Nye Counties, Nevada. DOE/NV/11718--1119. Las Vegas, NV. January 2006.

- 2006c. Characterization Report for the 92-Acre Area of the Area 5 Radioactive Waste Management Site, Nevada Test Site, Nevada. DOE/NV/11718--1154. Las Vegas, NV. June 2006.

—_, 2006d. Nevada Test Site 2005 Waste Management Monitoring Report, Area 3 and Area 5 Radioactive Waste Management Sites. DOE/NV/11718--1241 / DOE/NV/25946-021. Las Vegas, NV. August 2006.

_ 2005a. 2004 Annual Summary Report for the Area 3 and Area 5 Radioactive Waste Management Sites at the Nevada Test Site, Nye County, Nevada. Las Vegas, Nevada. January 2005.

_ _ 2005b. Low-Level Waste Inventory System User's Guide. Las Vegas, NV. March 2005. 
, 2005c. Integrated Closure and Monitoring Plan for the Area 3 and Area 5 Radioactive Waste Management Sites at the Nevada Test Site. DOE/NV/1178--449-Rev2. Las Vegas, NV. June 2005.

- 2005d. Nevada Test Site 2004 Waste Management Monitoring Report, Area 3 and Area 5 Radioactive Waste Management Sites. BN-NTS-05-0025. Las Vegas, Nevada. June 2005.

- 2005e. Hydrogeologic Characterization of the U-3at Collapse Zone. DOE/NV/11718--199-REV1. Las Vegas, NV. August 2005.

, 2005f. Post-Closure Inspection and Monitoring Report for Corrective Action Unit 110: Area 3 WMD U-3ax/bl Crater, Nevada Test Site, Nevada, for the Period July 2004-June 2005. DOE/NV-1075. Las Vegas, NV. August 2005.

- 2005g. Site Characterization Data from the U3ax/bl Exploratory Boreholes at the Nevada Test Site. DOE/NV/11718--003-REV.1. Las Vegas, NV. August 2005.

— 2005h. Nevada Test Site Environmental Report 2004. DOE/NV/11718--1080.

Las Vegas, NV. October 2005.

- 2005i. Radioactive Waste Disposal Operations Five-Year Strategic Plan, Fiscal Year 2006 to Fiscal Year 2010. DOE/NV/11718--1125. Las Vegas, NV. December 2005.

— , 2004a. Nevada Test Site 2003 Waste Management Monitoring Report: Area 3 and Area 5 Radioactive Waste Management Sites, Nevada Test Site. DOE/NV/11718--930. Las Vegas, Nevada. June 2004.

- 2004b. 2003 Annual Summary Report for the Area 3 and Area 5 Radioactive Waste Management Sites at the Nevada Test Site, Nye County, Nevada. Las Vegas, NV. 2004.

— 2003a. 2002 Annual Summary Report for the Area 3 and Area 5 Radioactive Waste Management Sites at the Nevada Test Site, Nye County Nevada, Review of the Performance Assessments and Composite Analyses. Las Vegas, NV. January 2003.

— 2003b. Nevada Test Site Routine Radiological Environmental Monitoring Plan. DOE/NV/11718--804. Las Vegas, NV. June 2003.

— 2003c. Annual Site Environmental Report - 2002, Nevada Test Site. DOE/NV/11718--842. Las Vegas, NV. October 2003.

_ 2002a. 2001 Annual Summary Report for the Area 3 and Area 5 Radioactive Waste Management Sites at the Nevada Test Site, Nye County, Nevada, Review of the Performance Assessments and Composite Analyses. Las Vegas, NV. February 2002.

_ Area 5 Radioactive Waste Management Sites. DOE/NV/11718--718. Las Vegas, NV. June 2002. 
,2002c. Maintenance Plan for the Performance Assessments and Composite Analyses for the Area 3 and Area 5 Radioactive Waste Management Sites at the Nevada Test Site. DOE/NV/11718--491, Rev 1. Las Vegas, NV. September 2002.

, 2001. Nevada Test Site 2000 Waste Management Monitoring Report, Area 3 and Area 5 Radioactive Waste Management Sites. DOE/NV/11718--582. Las Vegas, NV.

June 2001.

, 2000. Nevada Test Site 1999 Waste Management Monitoring Report, Area 3 and Area 5 Radioactive Waste Management Sites. DOE/NV 11718--425. Las Vegas, NV.

May 2000.

1999a. Lithology and Stratigraphy of Holes Drilled in LANL-Use Areas of the Nevada Test Site, Volume XIII 1991-1998. DOE/NV/11718--254. Las Vegas, NV. July 1999.

1999b. Characterization Report for Corrective Action Unit 110: Area 3 U-3ax/bl Disposal Unit Nevada Test Site, Nevada. DOE/NV--580. Las Vegas, NV. November 1999.

1999c. 1999 Ecosystem Monitoring Report: Area 3 and Area 5 Radioactive Waste Management Sites, Nevada Test Site. Unnumbered report. September 1999.

1999d. Bechtel Environmental Integrated Data Management System (BEIDMS). Las Vegas, NV.

1998a. Geology Report, Area 3 Radioactive Waste Management Site, Nye County, Nevada. DOE/NV/11718--195. Report to U.S. Department of Energy, Nevada Operations Office, Las Vegas, NV. January 1998.

, 1998b. Hydrogeologic Characterization of the Unsaturated Zone at the Area 3 Radioactive Waste Management Site. Volume 1: Data Interpretations. Volume 2: Data. DOE/NV/11718--210. Las Vegas, Nevada. February 1998.

1998c. Hydrogeologic Characterization of U-3bh Collapse Zone.

DOE/NV/11718--198. Las Vegas, NV. February 1998. Published as Attachment 2 of Hydrogeologic Characterization of the Unsaturated Zone at the Area 3 Radioactive Waste Management Site. Volume 1: Data Interpretations. Volume 2: Data.

DOE/NV/11718--210. Las Vegas, NV. February 1998.

1998d. Hydrogeologic Characterization of U-3bl Collapse Zone.

DOE/NV/11718--197. Published as Attachment 1 of Hydrogeologic Characterization of the Unsaturated Zone at the Area 3 Radioactive Waste Management Site. Volume 1: Data Interpretations. Volume 2: Data. DOE/NV/11718--210. Las Vegas, NV. February 1998.

1998e. Hydrogeologic Characterization of U-3at Collapse Zone.

DOE/NV/11718--199. Published as Attachment 3 of Hydrogeologic Characterization of the Unsaturated Zone at the Area 3 Radioactive Waste Management Site. Volume 1: Data Interpretations. Volume 2: Data. DOE/NV/11718--210. Las Vegas, NV. February 1998. 
—, 1997. Hydrogeologic Characterization of U-3at Collapse Zone: Data Report. Limited Distribution. Las Vegas, NV.

- 1996a. Hydrogeologic Characterization of U-3bh Collapse Zone. Limited Distribution. Las Vegas, NV. August 1996.

—, 1996b. Hydrogeologic Characterization of U-3bl Collapse Zone. Limited Distribution. Las Vegas, NV.

Becker, B. D., W. A. Clayton, and B. M. Crowe, 2002. Waste Management at the Nevada Test Site Fiscal Year 2001, Current Status. U.S. Department of Energy, DOE/NV11718--714. Las Vegas, NV.

Bhark, E. W., and G. Ruskauff, 2005. “Analysis of Responses from Hydraulic Testing of the Lower Carbonate Aquifer at Yucca Flat, Nevada Test Site, Nye County Nevada.” Presented at AGU Fall Meeting, December 5-9 2005, San Francisco, California. Stoller-Navarro Joint Venture/INTERRA Incorporated, Las Vegas, NV.

Black, P., K. Black, L. Stahl, M. Hooten, T. Stockton, and D. Neptune, 2001. Assessing the Probability of Inadvertent Human Intrusion at the Nevada Test Site Radioactive Waste Management Sites. DOE/NV--593. Las Vegas, NV. March 2001.

Blankennegal, R. K., and J. E. Weir, Jr., 1973. Geohydrology of the Eastern part of Pahute Mesa, Nevada Test Site, Nye County, Nevada. U.S. Geological Survey professional paper 712-B.

BN, see Bechtel Nevada.

CFR, see Code of Federal Regulations.

Clark, D., 2006. Personal communication to Wieland, Subject: None. March 28 and 30, 2006.

Code of Federal Regulations, 2001a. Title 10 CFR 835, “Occupational Radiation Protection,” revised as of January 1, 2001. 58 FR 658485, December 14, 1993, as amended at 63 FR 59679. November 4, 1998.

— June 10, 2001.

—, 2001c. Title 10 CFR 61.55, “Waste Classification,” 47 FR 27463. December 27, 1982; amended at 66 FR 55792, November 2, 2001.

— 1999. Title 40 CFR 265, "Interim Status Standards for Owners and Operators of Hazardous Waste Treatment Storage and Disposal Facilities.” Revised July 1, 1999.

— , 1996a. Title 40 CFR 61, "National Emission Standards for Hazardous Air Pollutants.” Revised July 1, 1996. 
1996b. Title 40 CFR 191, "Environmental Radiation Protection Standards for Management and Disposal of Spent Nuclear Fuel, High-Level, and Transuranic Radioactive Wastes.”

1991. Title 10 CFR 20, "Standards for Protection Against Radiation," 56 FR 23391. May 21, 1991.

Crowe, B. M., K. Leary, R. Jacobson, H. Bensinger, and M. Dolenc, 1999. “An Informal Expert Judgment Assessment of Subsidence Mitigation Options for Low Level Radioactive Waste Management Sites on the Nevada Test Site." In: Proceedings of the Waste Management Conference. LA-UR-99-285 Conf-990201. Los Alamos National Laboratory. Las Vegas, NV.

Crowe, B. M., P. Wallmann, and L. M. Bowker, 1998. "Probabilistic Modeling of Volcanism Data: Final Volcanic Hazard Studies for the Yucca Mountain Site.” In: Perry, F., B. M. Crowe, G. A. Valentine, J. Geissman, L. McFadden, S. Wells, M. Murrell, J. Poths, and L. Bowker, Volcanism Synthesis Report. Los Alamos National Laboratory, Los Alamos, NM.

Crowe, B. M., 1990. "Basaltic Episodes of the Yucca Mountain Region.” In: Proceedings, High-level Radioactive Waste Management, International Conference, Las Vegas, Nevada. American Nuclear Society, La Grange, IL, p.65-73.

Crowe, B. M., M. T. Vaniman, and W. J., Carr, 1983. Status of Volcanic Hazard Studies for the Nevada Nuclear Waste Storage Investigation. LA-9325-MS. Los Alamos National Laboratory, Los Alamos, NM.

Denton, R. C., 2006. Personal communication to Wieland, Subject: Waste Inventory History. July 26, 2006.

Desotell, L. T.; D. B. Hudson; V. Yucel; and J. T. Carilli, 2006. "Use of Long-Term Lysimeter Data in Support of Shallow Land Waste Disposal and Cover Design."

DOE/NV/11718--1148. WM'06 Conference, February 26-March 2, 2006, Tucson, AZ.

DOE, see U.S. Department of Energy, National Nuclear Security Administration Nevada Site Office.

Dolenc, M., 2005. Personal communication to Wieland, Subject: Waste Inventory History and Area 3 RWMS History. July 21, 2005.

Doorenbos, J., and W. O. Pruitt, 1977. Guidelines for Predicting Crop Water Requirements. FAO Irrigation and Drainage Paper No. 24, 2nd ed., FAO Rome, Italy. 156 pp.

Dreesen, D. R., and M. L. Marple, 1979. Uptake of Trace Elements and Radionuclides from Uranium Mill Tailings by Four-Wing Saltbush (Atriplex canescens) and Alkali Sacacton (Sporobolus airoides). LA-UR-79-3045. CONF-791140-1. 
Fenelon, J. M., 2005. Analysis of Ground-Water Levels and Associated Trends in Yucca Flat, Nevada Test Site, Nye County, Nevada, 1951-2003. United States Geological Survey Scientific Investigations Report 2005-5175, Carson City, NV. http://pubs.water.usgs.gov/sir2005/5175.

Foxx, T. S., G.. D. Tierney, and J. M. Williams, 1984a. Rooting Depths of Plants on Low-Level Waste Sites. LA-10253-MS.

— 1984b. Rooting Depths of Plants as Related to Biological and Environmental Factors. LA-10254-MS.

Grossman, R., 2006. Personal communications to Wieland, Subject: Air Quality. February 8, 2006, and April 19, 2006.

Gustafson, D. L., and W. Wharton, 2006. Personal communication to Wieland, Subject: Borehole Abandonment. March 16, 2006.

Hansen, D. J., 2005. Personal communication to Wieland, Subject: Vegetation. September 20, 2005.

Hansen, D. J., and W. K. Ostler, 2003. Rooting Characteristics of Vegetation Near Radioactive Waste Management Sites 3 and 5 at the Nevada Test Site. DOE/NV/11718--595. Report to National Nuclear Security Administration Nevada Operations Office, Las Vegas, NV. September 2003.

Hockett, S. L., and R. H. French, 1998. Evaluation of Recharge Potential at Crater U-5a. Desert Research Institute Publication 45160, DOE/NV/11508--32. Las Vegas, NV.

Hooten, M., 2006. Personal communication to Wieland, Subject: Termite and Ant Studies. April 13, 2006.

Hooten, M. M., J. T. Markwiese, T. G. Myles, P. Black, and R. Ryti , 2001. A Literature Review of Biotic Components, Processes, and Characteristics Central to Biotic Transport Modeling of Soils at the Nevada Test Site. Neptune and Company, Inc., Los Alamos, NM.

Hudson, R., 2006. Written communication to Wieland, Subject: Draft 2005 Waste Management Monitoring Report. May 23, 2006.

IT Corporation, 1997. Groundwater Flow Model Documentation Package (Phase I Data Analysis Documentation, Volume VI). Prepared for DOE/NV. Las Vegas, NV.

— 1996a. Groundwater Flow Model Documentation Package (Phase I Data Analysis Documentation, Volume VI). Prepared for DOE/NV. Las Vegas, NV.

, 1996b. Hydrologic Parameters Data Documentation Package (Phase I Data Analysis Documentation, Volume IV). ITLV/10972-181. Las Vegas, NV. 
Kao, C. S., D. K. Smith, and W. B. McKinnis, 1994. New Observations of Infiltration Through Fractured Alluvium in Yucca Flat, Nevada Test Site: A Preliminary Field Investigation. Lawrence Livermore National laboratory, UCRL-ID-116129. Mercury, NV. February 1994.

Laczniak, R. J., J. C. Cole, D. A. Sawyer, and D. A. Trudeau, 1996. Summary of Hydrogeologic Controls on Ground-Water Flow at the Nevada Test Site, Nye County, Nevada. U.S. Geological Survey Water-Resources Investigations Report 96-4109.

Levitt, D. G., and V. Yucel, 2002a. Infiltration Modeling to Support the Design of Closure Covers at the Radioactive Waste Management Sites at the Nevada Test Site (Abstract). Bechtel Nevada. Las Vegas, NV.

- 2002b. Potential Groundwater Recharge and the Effects of Soil Heterogeneity on Flow at Two Radioactive Waste Management Sites at the Nevada Test Site. DOE/NV/11718--609. Bechtel Nevada. Las Vegas, NV.

Levitt, D. G., M. J. Sully, B. L. Dozier, and C. F. Lohrstorfer, 1999. "Determining the Performance of an Arid Zone Radioactive Waste Site Through Site Characterization, Modeling and Monitoring." DOE/NV/11718--307. In: Proceedings of the Waste Management 1999 Conference, Tucson, Arizona.

Levitt, D. G., B. L. Dozier, J. M. Dixon, and L. T. Desotell, 1998a. "The Influence of Climate and Vegetation as Factors for Waste Cover Design." In: Proceedings of the DOE Nevada Vadose Zone Monitoring Workshop, September 24-25, 1998, Las Vegas, Nevada.

Lyons, C., 2006. Personal communication to Wieland, Subject: Radiologically Contaminated Sites. April 13, 2006.

Miller, J. J., 1996. Flood Assessment for the Area 3 Radioactive Waste Management Site, Nevada Test Site, Nye County, Nevada. Bechtel Nevada. Las Vegas, NV. June 1996.

National Nuclear Security Administration Nevada Site Office, 2005a. FY 2006 Performance Evaluation Plan, Performance Period: October 1, 2005 through June 30, 2006. Las Vegas, NV. March 2005.

— , 2005b. Nevada Test Site Waste Acceptance Criteria. DOE/NV-325, Rev. 6.02. Las Vegas, NV. October 2006.

—, 2001. Closure Report for Corrective Action Unit 110: Areas [report cover typo] 3 RWMS U-3ax/bl Disposal Unit, Nevada Test Site, Nevada. DOE/NV-733, Rev. 1. Environmental Restoration Division. Las Vegas, NV. August 2001.

NDEP, see Nevada Division of Environmental Protection.

Nevada Administrative Code, 1997. NAC 534.420. "Plugging of Well: General Requirements." May 19, 1981. Revised 12/30/97.

Nevada Department of Conservation and Natural Resources, 2002. Nevada Natural Resources Status Report, Nevada Natural Resources Plan. August 2002. Electronic copy accessed 1/9/2006. http://denr.nv.gov/ 
Nevada Division of Environmental Protection, 2005. Permit for a Hazardous Waste Facility, Permit No. HW0021. December 1, 2005.

_ 2000. Permit for a Hazardous Waste Facility, Permit No. NEV HW009. November 2000.

Nevada Division of Environmental Protection, U.S. Department of Energy, and U.S. Department of Defense, 1996. Federal Facility Agreement and Consent Order (FFACO) of 1996. April 1996.

Nevada State Demographer's Office, 2005. "Nevada County Population Estimates. July 1, 1986, to July 1, 2004, Includes Cities and Towns." Prepared for the Nevada Department of Taxation in Conjunction with the Nevada Small Business Development Center. Reno, NV.

NNSA/NSO, see National Nuclear Security Administration Nevada Site Office (U.S. Department of Energy).

Obi, C. M., 2006. Personal communications to Wieland, Subject: Redbook Borehole Database. March 13 and April 11, 2006.

Obi, C. M., G. J. Shott, C. J. Muller, and L. E. Barker, 1996. Preliminary Estimates of Future Waste Subsidence, Hydrogeologic Impact, and Contaminant Concentrations for Area 3 RWMS Disposal Units at the NTS. Bechtel Nevada, Las Vegas, NV. October 1996.

O'Farrell, T. P., and L. A. Emery, 1976. Ecology of the Nevada Test Site: A Narrative Summary and Annotated Bibliography. NVO-167. National Technical Information Service Publication, Springfield, VA.

Ostler, W. K., D. C. Anderson, D. B. Hall, and D. J. Hansen, October 2002. New Technologies to Reclaim Arid Lands Users Manual. DOE/NV/11718--731. Bechtel Nevada, Las Vegas, NV.

Ostler, W. K., D. J. Hansen, D. C. Anderson, and D. B. Hall, 2000. Classification of Vegetation on the Nevada Test Site. DOE/NV/11718--477. Bechtel Nevada, Las Vegas, NV. December 2000.

Planerer, H. N., 1996. Siting Criteria for Angle Drilling Under the U-3ah/at Disposal Unit. Los Alamos National Laboratory Report LA-UR-96-1679. Los Alamos, NM.

Rehfeldt, K., O. Drici, J. Renier, and J. Marie, 1995. Hydraulic Test Parameter Data Task - Data Documentation (Draft). IT Corporation, Las Vegas, NV.

Rose, T. P., A. B. Kersting, L. J. Harris, G. B. Hudson, D. K. Smith, R. W. Williams, D. R. Loewen, E. J. Nelson, P. G. Allen, F. J. Ryerson, G.. A. Pawloski, C. A. Laue, and J. E. Moran, 2003. Hydrologic Resources Management Program and Underground Test Area Project, FY 2001-2002 Progress Report. UCRL-ID-154357. Lawrence Livermore National Laboratory. August 15, 2003. 
Schmeltzer, J. S., L. E. Barker, and D. O. Blout, 1996. Site Characterization Data from the U-3ax/bl Exploratory Boreholes at the NTS. DOE/NV/11718--003. Bechtel Nevada. Las Vegas, NV. April 1996.

Schoff, S. L., and J. E. Moore, 1964. Chemistry and Movement of Ground Water, Nevada Test Site. Report TEI-838. U.S. Department of the Interior Geological Survey. Preliminary report not edited for conformity with Geological Survey format. Prepared on behalf of the U.S. Atomic Energy Commission.

Seaber, P. R., E. D Stowers, and R. H. Pearl, 1997. Bibliography of Reports on Studies of the Geology, Hydrogeology and Hydrology at the Nevada Test Site, Nye County, Nevada, from 1951 to 1996. Publication No. 45156. DOE/NV/11508--25. Water Resources Center of the Desert Research Institute of the University and Community College System of Nevada and the Nevada Operations Office of the Department of Energy, Las Vegas, NV. April 1997.

Sheppard, S. C., and W. G. Evenden, 1988. "Critical Compilation and Review of Plant/Soil Concentration Ratios for Uranium, Thorium, and Lead." Journal of Environmental Radioactivity, 8:255-285.

Shott, G. J., V. Yucel, M. J. Sully, L. E. Barker, S. E. Rawlinson, and B. A. Moore, 2000. Performance Assessment/Composite Analysis for the Area 3 RWMS at the NTS, Nye County, Nevada, Revision 2.1. DOE/NV--491-REV 2.1. Bechtel Nevada, Las Vegas, NV. October 2000.

Shott, G. J., L. E. Barker, S. E. Rawlinson, M. J. Sully, and B. A. Moore, 1998. Performance Assessment of the Area 5 RWMS at the NTS, Nye County, Nevada. DOE/NV/11718--176, Revision 2.1. Bechtel Nevada, Las Vegas, NV. January 1998.

Shott, G. J., V. Yucel, M. J. Sully, L. E. Barker, S. E. Rawlinson, and B. A. Moore, 1997. Performance Assessment/Composite Analysis for the Area 3 RWMS at the NTS, Nye County, Nevada, Revision 2.0. DOE/NV--491. Bechtel Nevada, Las Vegas, NV. September 1997.

Stoller-Navarro, 2006. Geochemical and Isotopic Evaluation of Groundwater Movement in Corrective Action Unit 97: Yucca Flat/Climax Mine, Nevada Test Site, Nevada. S-N/99205-070. Underground Test Area Project. February 2006.

__ 2005. Analysis of Well ER-6-2 Testing, Yucca Flat FY 2004 Testing Program, Nevada Test Site, Nye County, Nevada. S-N/99205--053. Las Vegas, NV. July 2005.

Sutter, G. W., II, R. J. Lemoore, and E. D. Smith, 1993. "Compacted Soil Barriers at Abandoned Landfill Sites are Likely to Fail in the Long Term." Journal of Environmental Quality, 22(2):217-226.

Tierney, G. D., and T. S. Foxx, 1987. Root Lengths of Plant on Los Alamos National Laboratory Lands. LA-10865-MS.

Traynor, J., 2006. Personal communication to Wieland, Subject: Radiologically Contaminated Sites. March 27, 2006. 
Tyler, S. W., J. B. Chapman, S. H. Conrad, D. P. Hammermeister, D. O. Blout, J. J. Miller, M. J. Sully, and J. M Ginanni, 1996. "Soil-Water Flux in the Southern Great Basin, United States: Temporal and Spatial Variations over the Last 120,000 Years." Water Resources Research 32(6):1481-1499.

USGS, see U.S. Geological Survey.

U.S. Census Bureau, 2004. News Release, June 24, 2004, by Robert Bernstein, Public Information Office, Washington, D.C. Electronic version accessed from U.S. Census Bureau web site on 1/9/2006. http://www.census.gov/PressRelease/www/releases/archives/population/001856.html.

-, 2002a. "GCT-PH1. Population, Housing Units, Area, and Density: 2000; Census 2000 Summary File 1 (SF 1) 100-Percent Data; Geographic Area: Nevada-County" data table and also the figure "Population Density by Census Tract" in Census 2000: Nevada profile, Census 2000 Profile C2KPROF/00-NV, August 2002.

, 2002b. Demographic Trends in the 20th Century. Census 2000 Special reports CENSR-4. Washington, D.C. November 2002.

U.S. Department of Energy, 2003a. DOE Order 450.1, "Environmental Protection Program," U.S. Department of Energy, Washington, D.C., January 15, 2003.

—, 2003b. DOE Order 231.1A. "Environmental Safety and Health Reporting." U.S. Department of Energy, Washington, D.C. August 19, 2003.

— , 2002. U.S. DOE Standard DOE-STD-1153-2002, “A Graded Approach for Evaluating Radiation Doses to Aquatic and Terrestrial Biota." U.S. Department of Energy, Washington, D.C. July 2002.

—, 2001a. DOE M 435.1-1, "Radioactive Waste Management Manual.” U.S. Department of Energy, Washington, D.C., June 19, 2001. , 2001b. DOE Order 414.1A, “Quality Assurance.” U.S. Department of Energy, Washington, D.C., September 29, 1999. Change 1 approved July 12, 2001.

—, 2001c. DOE Order 435.1, "Radioactive Waste Management." U.S. Department of Energy, Washington, D.C., August 28, 2001, Change 1. Original Order approved July 9, 1999.

, 2000a. Closure Plan for Corrective Action Unit 110: Area 3 RWMS U-3ax/bl Disposal Site, Nevada Test Site, Nevada. DOE/NV--647. Nevada Operations Office. Las Vegas, NV. August 2000.

Nevada Operations Office, 2000b. The Corrective Action Investigation Plan for Corrective Action Unit 97: Yucca Flat/Climax Mine, Nevada Test Site, Nevada. DOE/NV--659. Nevada Operations Office, Las Vegas, NV. September 2000. 
1999. Disposal Authorization Statement for the Department of Energy, Nevada Operations Office, Area 3 Radioactive Waste Management Site Low-Level Radioactive Waste Disposal Facility. October 20, 1999. http://www.deprep.org/1999/tb99o20a.pdf.

, 1996a. Final Environmental Impact Statement for the Nevada Test Site and Off-Site Locations in the State of Nevada. DOE/EIS-0243. Las Vegas, NV. August 1996.

— 1996b. Guidance for Composite Analysis for the Impact of Interacting Source Terms for the Radiological Protection of the Public from Department of Energy Low-Level Waste Disposal Facilities. Washington, D.C.

- 1993. DOE Order 5400.5, Chg. 2. "Radiation Protection of the Public and the Environment." U.S. Department of Energy, Washington, D.C. January 7, 1993.

— 1988. DOE Order 5820.2A "Radioactive Waste Management." U.S. Department of Energy, Washington, D.C. (superseded by 435.1). September 26, 1988.

U.S. Geological Survey, 2006. USGS/DOE Cooperative Studies program Web site, Nevada Test Site Area 3 well data. Extracted on March 9, 2006, from Internet URL: http://nevada.usgs.gov/doe $\% 5$ Fnv/ntsarea3.cfm.

Van Remortel, R. D., Y. J. Lee, and K. E. Snyder. 2005. Soil Characterization Database for the Area 3 Radioactive Waste Management Site, Nevada Test Site, Nye County, Nevada. DOE/NV/11718--1016. Lockheed Martin Services Group, Las Vegas, NV. January 2005.

Wallace, A., E. M. Romney, and R. B. Hunter, 1980. "The Challenge of a Desert: Revegetation of Disturbed Desert Lands.” In: Great Basin Naturalist Memoirs, No. 4. Brigham Young University.

Wallace, A., and E. M. Romney, 1972. Radioecology and Ecophysiology of Desert Plants at the Nevada Test Site. National Technical Information Service Publication TID-25954, Springfield, VA.

Warren, R., 2006. Personal communications to Wieland, Subject: Biota, TLD, and Radon Monitoring. March 14 and 15, 2006.

Webb, R. H., M. B. Murov, T. C. Esque, D. E. Boyer, L. A. DeFalco, D. F. Haines, D. Oldershaw, S. J. Scoles, K. A Thomas, J. B. Blainey, and P. A. Medica, 2003. Perennial Vegetation Data from Permanent Plots on the Nevada Test Site, Nye County, Nevada. U.S. Geological Survey Open File Report 03-336.

Whicker, F. W., 1978. "Biological Interactions and Reclamation of Uranium Mill Tailings." Symposium on Uranium Mill Tailings Management, Fort Collins, CO. November 20-21, 1978.

Williams, J. M., B. D. Rodriguez, and T. H. Asch, 2005. Magnetotelluric Data, Central Yucca Flat, Nevada Test Site, Nevada. Open-File Report 2005-1238. United States Geological Survey. Reston, VA. 
Wills, C. A., and W. K. Ostler, 2001. Ecology of the Nevada Test Site: An Annotated Bibliography, With Narrative Summary, Keyword Index, and Species List. DOE/NV/11718--594. December 2001.

Wilson, G. V., D. M Ely, S. L. Hockett, and D. R. Gillespie, 2000. "Recharge from a Subsidence Crater at the Nevada Test Site" In: Soil Science Society of America Journal, 64:1570-1581.

Winkel, V. K., J. P. Angerer, D. B. Hall, M. W. Fariss, and K. R. Johnejack, 1995. Plant and Burrowing Animal Characteristics, Integrated Closure Program for the Area 3 and Area 5 Radioactive Waste Management Sites, Nevada Test Site. U.S. Department of Energy, Nevada Operations Office, Las Vegas, NV. March 1995.

Winograd, I. J., and W. Thordarson, 1975. Hydrogeologic and Hydrochemical Framework, South-Central Great Basin, Nevada-California, with Special Reference to the Nevada Test Site. U.S. Geological Survey Professional Paper 712-C.

Wirth, S., T. Brown, and W. Beyler, 1999. Native Plant Uptake Model for Radioactive Waste Disposal Areas at the Nevada Test Site. SAND98-1789. Sandia National Laboratories and IT Corporation, Albuquerque, New Mexico. September 1999.

Yucel, V., G.. J. Shott; and L. E. Barker, 1996. Screening Analysis of Interacting Source Terms for the Area 3 RWMS Facility Composite Analysis. Las Vegas, Nevada. 


\title{
APPENDIX A \\ ANNOTATED BIBLIOGRAPHY OF SELECTED REFERENCES RELEVANT TO THE AREA 3 RADIOACTIVE WASTE MANAGEMENT SITE
}

\author{
Bechtel Nevada, 2006a. Fiscal Year 2005 Annual Summary Report for the Area 3 and \\ Area 5 Radioactive Waste Management Sites at the Nevada Test Site, Nye County, Nevada. \\ Las Vegas, Nevada. January 24, 2006.
}

Annual review of Performance Assessments (PAs) and Composite Analyses (CAs). Evaluates $\mathrm{PA}$ and CA validity with respect to operational changes, monitoring results, research and development results, and updated inventory data. Provides new projections of future inventories at closure.

A preliminary Area 3 Radioactive Waste Management Site (RWMS) PA model was developed using GoldSim ${ }^{\circledR}$. The preliminary model results indicate a high probability of compliance with all performance objectives and the PA results remain valid. The $\mathrm{CA}$ remains valid. The $\mathrm{CA}$ will need to be updated when the Yucca Flat Underground Test Area 1,000-year groundwater contaminant boundary is determined.

Bechtel Nevada, 2006b. A Hydrostratigraphic Model and Alternatives for the Groundwater Flow and Contaminant Transport Model of Corrective Action Unit 97: Yucca Flat-Climax Mine, Lincoln and Nye Counties, Nevada. DOE/NV/11718--1119. Las Vegas, Nevada. January 2006.

Describes the complex three-dimensional hydrostratigraphic framework model for the Yucca Flat and Climax Mine former nuclear testing areas at the Nevada Test Site (NTS). The model uses Earth Vision ${ }^{\circledR}$ software and incorporates diverse geological and geophysical data collected over the past 50 years.

Bechtel Nevada, 2005a. 2004 Annual Summary Report for the Area 3 and Area 5 Radioactive Waste Management Sites at the Nevada Test Site, Nye County, Nevada. Las Vegas, Nevada. January 2005.

Annual review of Performance Assessments and Composite Analyses. Evaluates PA and CA validity with respect to operational changes, monitoring results, research and development results, land-use changes, and updated inventory data. Provides new projections of future inventories at closure.

No significant changes in operation, monitoring results, or research and development results for the Area 3 RWMS that would impact PA validity. No significant changes were identified that alter CA results or conclusions. Current inventory estimates for the Area 3 RWMS differ significantly from the fiscal year (FY) 1996 inventory. Recommended quantitative evaluation of inventory changes using the GoldSim Area 3 RWMS Model in FY 2005. 


\section{Bechtel Nevada, 2005e. Hydrologic Characterization of U-3at Collapse Zone. DOE/NV/11718--199-REV1. Las Vegas, Nevada. August 2005. (Revision of 1997 report by Bechtel Nevada: Hydrogeologic Characterization of U-3at Collapse Zone: Data Report.)}

The subsidence crater was formed by an underground nuclear test in 1963, and has been used for bulk low-level radioactive waste disposal since 1988. Characteristics and properties of the U-3bat crater collapse zone were determined from 56 cores collected from two 30-degree angle boreholes, U-3at-D1 drilled to a total vertical depth of 147.3 meters $(\mathrm{m})$ and U-3at-D2 drilled to a vertical depth of $78.3 \mathrm{~m}$ from the south edge of the crater. Selected alluvial samples were analyzed for particle density, bulk density, water retention, saturated and unsaturated hydraulic conductivity, water content, water potential, chloride, carbonate, stable isotopes, and tritium. Test records were reviewed to identify potential preferential transport pathways.

Physical and hydraulic properties were typical for alluvium at the NTS. Water content ranged from 0.05 to 0.33 cubic meters per cubic meter $\left(\mathrm{m}^{3} / \mathrm{m}^{3}\right)$ and tended to increase with depth. Water potential values ranged from -10.7 MegaPascals to greater than -0.40 MegaPascals (MPa). Below $120.1 \mathrm{~m}$, water potentials were consistently greater than the upper measurable limit. Tritium concentrations in pore water extracted from cores collected from ground surface to a depth of $118.9 \mathrm{~m}$ were below detection limits. Below this depth, concentrations of tritium in pore water generally increased with depth. The maximum detected was 2,200 picoCuries per liter $(\mathrm{pCi} / \mathrm{L})$ tritium in the sample from $146.9 \mathrm{~m}$ below ground surface. The tritium is attributable to past nuclear testing. Stable isotopic composition of pore water samples were more depleted than weighted mean values for winter precipitation, suggesting pore water in alluvium below the U-3at collapse zone below $30 \mathrm{~m}$ must have infiltrated under cooler, past climate conditions. All but one sample plotted below the local meteoric water line, suggesting evaporation. Chloride accumulation in the upper $14.9 \mathrm{~m}$ of the profile is typical of arid regions and indicates a zone of evaporation.

The second boring was drilled, after modifying the process to preclude any potential introduction of fluids, and sampled over the 47.5- to 78.3-m interval to confirm that the drilling process had not introduced water through condensation in the compressed air system or oil to the first borehole. Results for water content, water potential, and stable isotope concentrations tests on core samples from the two borings were consistent.

Geologic descriptions of the core samples detected no evidence of preferential water flow pathways. Thirty-seven downhole cables were required for the underground nuclear test but it is unknown if they currently provide a pathway for water movement through the alluvium. Postshot boreholes from testing may be unplugged. 
Bechtel Nevada, 2005g. Site Characterization Data from the U3ax/bl Exploratory Boreholes at the Nevada Test Site. DOE/NV/11718--003-REV 1. Las Vegas, Nevada. August 2005. (Revision of 1996 report by John S. Schmeltzer, Lawrence E. Barker and Daniel O. Blout.)

Two 45-degree borings (UE-3bl-D1 and UE-3bl-U1) were drilled to approximately $50 \mathrm{~m}$ vertical depth at the Area 3 RWMS to obtain samples and compare hydrogeologic properties of alluvium below the crater with those of adjacent undisturbed alluvium. It is unclear if UE-3bl-D1 intercepted the chimney resulting from underground nuclear testing. Selected core samples were tested for various combinations of tests, including: physical and hydraulic properties (saturated hydraulic conductivity, moisture retention curves, gravimetric and volumetric water content, dry bulk density, porosity, particle size distribution, hydrometer, and particle density), cation exchange capacity, unenriched tritium analysis, water potential, water content, density, stable isotopes, inorganic carbon, chloride-bromide, and air permeability. Selected cuttings samples were checked for gravimetric water content and tritium. Samples and collection equipment were also radiologically surveyed. The boreholes are covered and not instrumented. Soil samples were visually described and classified.

Bechtel Nevada, 1998a. Geology Report, Area 3 Radioactive Waste Management Site, DOE/Nevada Test Site, Nye County, Nevada. DOE/NV/11718--195. Las Vegas, Nevada. January 1998.

Summary of 1996 and 1997 surficial geologic studies. Studies evaluated potential for future volcanism and activity of the Area 3 Fault to impact waste disposal operations at the Area 3 RWMS. Scope included a literature review; excavation and evaluation of two trenches to look for evidence of near-surface movement prior to nuclear testing; and the development of an updated surface geomorphic map with unit names consistent with those used in recent studies of Northern Frenchman Flat.

Local and regional studies of volcanic risk suggest regional volcanic activity within the next 1,000 years is unlikely. There is no evidence of post Miocene volcanism in the area. No major vertical displacement of the Area 3 fault has occurred since the Early Holocene and probably since the Middle Pleistocene. Area 3 RWMS is unlikely to be affected by Area 3 Fault within the 1,000-year regulatory compliance period.

Bechtel Nevada, 1998b. Hydrogeologic Characterization of the Unsaturated Zone at the Area 3 Radioactive Waste Management Site. DOE/NV/11718--210. Las Vegas, Nevada. February 1998.

Compilation and interpretation of characterization data regarding the hydrogeologic properties and processes of the unsaturated zone in the vicinity of the Area 3 RWMS. Evaluation of the characteristics of both undisturbed alluvium and the collapse zones below the craters. Development of a conceptual hydrogeologic model of the unsaturated zone using meteorological data, lysimeter data, 
and borehole core data from seven boreholes drilled in the Area 3 RWMS in the 1980s. Evaluation of the potential for runoff to collect in the subsidence craters and locally enhance infiltration of precipitation. Identification of cables, pipe stems, boreholes, and other features from past testing, which may act as potential preferential pathways for the movement of water down through the alluvium.

\section{Bechtel Nevada, 1996a. Hydrogeologic Characterization of U-3bh Collapse Zone. Las Vegas, Nevada. August 1996.}

The subsidence crater at U-3bh is from a 1962 underground nuclear test.

Characteristics and properties of the U-3bh crater collapse zone were determined from cores collected from two 64.5-m boreholes, U-3bh-C1 and U-3bh-C2. The boreholes were not drilled deeper due to encountered gamma activity attributed to a partial containment failure that allowed short-lived gaseous precursors to migrate upward during formation of the collapse zone following the underground test. Selected cores were analyzed for particle density, particle size, bulk density, water retention, hydraulic conductivity, water content, water potential, chloride, carbonate, stable isotopes, and tritium. Test records were reviewed to identify potential preferential transport pathways.

Particle size distributions, particle density, and dry bulk densities were similar between cores and between boreholes and consistent with values from undisturbed alluvium. Variation of water potential with depth and environmental tracer data suggest there have been multiple infiltration events. The two boreholes showed differences in infiltration histories. Water moved much deeper at $\mathrm{C} 1$ than at $\mathrm{C} 2$ although the alluvium is very similar and the boreholes are less than $14 \mathrm{~m}$ apart. The influence of evaporation on the isotopic composition of pore water was observed in the upper $50 \mathrm{~m}$ at $\mathrm{C} 1$ and $30 \mathrm{~m}$ depth at $\mathrm{C} 2$.

The tritium observed in the upper $62 \mathrm{~m}$ of the U-3bh collapse zone is thought to have been introduced at the surface of the crater and transported downward. Concentrations of tritium were orders of magnitude higher than expected if the only source had been atmospheric deposition. Whether elevated water contents observed in the upper $50 \mathrm{~m}$ were due to precipitation or the introduction of tritiated water is unknown.

\section{Bechtel Nevada, 1996b. Hydrogeologic Characterization of U-3bl Collapse Zone. Las Vegas, Nevada. November 1996.}

The subsidence crater at U-3bl is from a 1962 underground nuclear test, and was developed for disposal of bulk low-level radioactive waste and low-level mixed waste. Characteristics and properties of the U-3bl crater collapse zone were determined from cores collected within the 42- to 96.6-m vertical depth interval from a 45 degree angle boring drilled from the south edge of the crater, U-3bl-D2. Selected cores were analyzed for particle density, particle size, bulk density, water retention, hydraulic conductivity, water content, water potential, chloride, carbonate, stable isotopes, and tritium. Test records and data related to characterization of the collapse zone are provided as a report in an appendix. 
Physical and hydraulic properties were typical of NTS alluvium. Water content values ranged from 0.08 to $0.20 \mathrm{~m}^{3} / \mathrm{m}^{3}$, with a general increase with depth. Water potentials ranged from $-1.9 \mathrm{MPa}$ to $-0.41 \mathrm{MPa}$, and varied, but with an overall trend to increase with depth. Stable isotope compositions of porewater in samples from below $40 \mathrm{~m}$ suggest the water infiltrated under cooler, past climate conditions. Tritium concentrations varied with depth. The highest measured value was $12,150 \mathrm{pCi} / \mathrm{L}$ in a sample from $75.05 \mathrm{~m}$ depth. Concentrations are greater than expected from atmospheric deposition of tritium, but not at a level to raise environmental concerns. Test records indicate postshot holes were probably left unplugged, but with a closure at the top of the surface casing.

Fenelon, J. M., 2005. Analysis of Groundwater Levels and Associated Trends in Yucca Flat, Nevada Test Site, Nye County, Nevada 1951-2003. United States Geological Survey. Scientific Investigations Report 2005-5175 (electronic).

The U.S. Geological Survey (USGS) quality assured and analyzed water level measurement data collected from 216 wells in the Yucca Flat Area between 1951 and 2003. Compiled other data needed to compute hydraulic heads: well completion data, borehole deviations, measuring points, water temperatures, and lithologic units contributing water. Analyzed trends. Water level fluctuations are potentially attributable to: natural variations in recharge, equilibration following well development, withdrawals, recharge, earthquakes, underground nuclear tests, land subsidence, barometric pressure, and earth tides. Hydrogeologic units and discussion are based on 1996 and earlier publications and do not incorporate more recent interpretations. Report includes Microsoft Access ${ }^{\circledR}$ database.

PDF file accessed January 4, 2006, at http://pubs.usgs.gov/sir/2005/5175/

Hansen, D. J., and W. K. Ostler, 2003. Rooting Characteristics of Vegetation Near Area 3 and 5 Radioactive Waste Management Sites at the Nevada test Site. DOE/NV/11718--595. Las Vegas, Nevada. September 30, 2003.

Survey or prior NTS ecological studies and summarization of relevant data, results of recent field studies to measure shrubs by species at three plots near the Area 3 RWMS and two at the Area 5 RWMS, correlation of findings with data elsewhere on the NTS, review of earlier performance assessment documents and evaluation of model assumptions for bioturbation based on current data.

Concluded that if the climate changes to cooler temperatures and higher precipitation, the Area 5 and Area 3 RWMSs would be shrublands not woodlands. Historical and recent site observations of shrub roots suggest that root depth rarely exceeds $2 \mathrm{~m}$ at the NTS, although a few individual roots have been observed as deep as $8 \mathrm{~m}$. Most roots are confined to the near surface, closely correlated to the availability of soil moisture and plant nutrients.

Recommend to reduce uncertainty in transport models through further research to obtain correlation factors for living volume to biomass and root to shoot ratios, additional characterization of rooting profiles, excavation of mature shrubs that had been transplanted onto deeply disturbed soils and study of roots as an analog 
to revegetation of landfill covers, and further characterization of rooting depths of big sagebrush plants in pinyon-juniper/bigsagebrush plants communities to indicate rooting characteristics of this species under future potential cooler wetter climactic conditions.

Miller, J. J., 1996. Flood Assessment for the Area 3 Radioactive Waste Management Site, Nevada Test Site, Nye County, Nevada. Bechtel Nevada, Las Vegas, Nevada. June 30, 1996.

Study was to determine if the Area 3 RWMS was within a Federal Emergency Management Agency (FEMA) 100-year flood hazard and to provide estimates of 100 -year and 500-year discharges for use in design of flood protection. Rainfall/runoff models were used to estimate flood discharges. Curve numbers, depth of precipitation, and lag times were optimized to minimize skew. The 500year discharges were extrapolated from the models of 2-year, 10-year, 25-year, and 100 -year return periods.

Concluded the Area 3 RWMS is not located in the FEMA 100-year, 6-hour flood hazard zone of either the Jangle Ridge or Paiute Ridge alluvial fan. Calculated 100-year and 500-year sheetflow depths are less than $(0.3 \mathrm{~m})$ so the Area 3 RWMS is also not within 100-year, 6-hour or 500-year, 6-hour sheetflow flood hazard zones.

\section{Stoller-Navarro, 2006. Geochemical and Isotopic Evaluation of Groundwater Movement in Corrective Action Unit 97: Yucca Flat/Climax Mine, Nevada Test Site, Nevada. Underground Test Area Project. S-N/99205-070. February 2006.}

Performed comprehensive geochemical evaluation of the groundwater flow system in Corrective Action Unit 97 to identify probable pathways for groundwater flow through the Lower Carbonate Aquifer (LCA) and evaluate transit times between selected sample sites. Geochemical study provides independent verification of flow models. Compiled existing data, constructed mixing models using conservative tracer data (delta deuterium, delta oxygen-18 and chloride) to determine flow paths, evaluated strontium and ${ }^{87} \mathrm{Sr} /{ }^{86} \mathrm{Sr}$ isotopic data to assess flow paths and degree of equilibration with various rock types, modeled geochemical reactions with PHREEQC and NETPATH along flow paths to verify mixing models, and estimated groundwater travel times using carbon isotope data.

Groundwater enters the basin through mountain front recharge and inflow from Emigrant Valley through low-permeability rocks in the Halfpint Range. Groundwater moves southward along the eastern and western sides of the basin. Modeled transit times indicate groundwater flow is very slow. Transit times of 16,000 to 24,000 years between Well UE-10j in northern Yucca Flat to well WW-C in southern Yucca Flat suggest linear groundwater velocity of 1.3 to 1.9 meters per year (m/yr). Between well ER-7-1 and ER-6-1\#2, the 6,500-year transit time yielded a similar flow velocity of $1.7 \mathrm{~m} / \mathrm{yr}$. The small inflows from the north appear to limit the flow rather than the hydraulic conductivity of the LCA. Flow velocities are higher in the southeast part of the basin $(4.3 \mathrm{~m}$ to $13 \mathrm{~m} / \mathrm{yr}$ between well ER-3-1 and WW-C), where there is no lower clastic 
confining unit above the LCA. Geochemical data from some wells in the west central part of the basin show potential evidence of groundwater leakage from the volcanic aquifer down into the LCA. Vertical leakage through the volcanic confining unit and lateral flow through the LCA are slow.

Van Remortel, R. D., Y. J. Lee, and K. E. Snyder, 2005. Soil Characterization Database for the Area 3 Radioactive Waste Management Site, Nevada Test Site, Nye County, Nevada. DOE/NV/11718--1016. Lockheed Martin Services Group, Las Vegas, Nevada. January 2005.

Microsoft EXCEL 5.0 spreadsheet database of site characterization data. The database lists data in parameter groups: sample and site characteristics, United States Department of Agriculture particle size fractions, chemical parameters, and American Society for Testing Materials Unified Soil Classification System particle size fractions. Document includes no analysis or interpretation of the data.

Williams, J. M., B. D. Rodriguez, and T. H. Asch, 2005. Magnetotelluric Data, Central Yucca Flat, Nevada Test Site, Nevada. Open File Report 2005-1238. United States Geological Survey. Reston, Virginia.

One of four data reports documenting magnetotelluric geophysical surveys that the USGS conducted in and near Yucca Flat to characterize the pre-Tertiary confining units. A major goal was to define the thickness and lateral extent of the upper clastic confining unit in Yucca Flat. Presents methods and results without interpretation. 
This Page Intentionally Left Blank 


\section{APPENDIX B \\ GROUNDWATER QUALITY DATA}

Table B-1. STATION ID: USGS WATER WELL A

\begin{tabular}{|c|c|c|c|c|c|c|c|c|c|c|c|c|c|c|}
\hline \multirow[b]{2}{*}{$\begin{array}{l}\text { SAMPLE } \\
\text { DATE }\end{array}$} & \multirow[b]{2}{*}{ SAMPLE ID } & \multirow[b]{2}{*}{\begin{tabular}{|l} 
TOP \\
DEPTH \\
\end{tabular}} & \multirow[b]{2}{*}{\begin{tabular}{|l} 
SAMPLE \\
TYPE
\end{tabular}} & \multirow[b]{2}{*}{$\begin{array}{l}\text { ANALYSIS } \\
\text { CODE }\end{array}$} & \multirow[b]{2}{*}{ METHOD CODE } & \multirow[b]{2}{*}{ ANALYTE NAME } & \multirow[b]{2}{*}{ RESULT } & \multirow[b]{2}{*}{ UNITS } & \multirow[b]{2}{*}{ ERROR } & \multirow{2}{*}{$\begin{array}{l}\text { SAMPLE } \\
\text { QUANTITATION } \\
\text { LIMIT }\end{array}$} & \multirow[b]{2}{*}{$\begin{array}{l}\text { DETECTION } \\
\text { LIMIT }\end{array}$} & \multicolumn{3}{|c|}{ QUALIFIER CODES } \\
\hline & & & & & & & & & & & & LAB & REVIEW & CODE 1 \\
\hline \begin{tabular}{|l|}
$12 / 13 / 1999$ \\
\end{tabular} & EM00001371 & & $\mathrm{N}$ & REG & E310.1 & BICARBONATE & 110 & $M G / L$ & & 2 & & & & \\
\hline 12/13/1999 & EM00001371 & & $\mathrm{N}$ & LR1 & E310.1 & BICARBONATE & 107 & $M G / L$ & & 2 & & & & \\
\hline 12/13/1999 & EM00001371 & & $\mathrm{N}$ & REG & sW6010B & CALCIUM & 22000 & UG/L & & 22.5 & & & & \\
\hline $12 / 13 / 1999$ & EM00001371 & & $\mathrm{N}$ & LR1 & SW6010B & CALCIUM & 22800 & UG/L & & 22.5 & & & & \\
\hline 12/13/1999 & EM00001371 & & $\mathrm{N}$ & REG & E310.1 & CARBONATE (AS CO3) & 2 & $M G / L$ & & 2 & 2 & $\mathrm{U}$ & & \\
\hline 12/13/1999 & EM00001371 & & $\mathrm{N}$ & LR1 & E310.1 & CARBONATE (AS CO3) & 2 & $M G / L$ & & 2 & & $U$ & & \\
\hline \begin{tabular}{|l|}
$12 / 13 / 1999$ \\
\end{tabular} & EM00001372 & & $N$ & & L-E10602PC & CESIUM-137 & 62 & $\mathrm{pCi} / \mathrm{L}$ & 27.2 & & 47.7 & & & \\
\hline 12/13/1999 & EM00001371 & & $\mathrm{N}$ & REG & EPA300.0 & CHLORIDE & 22.3 & $M G / L$ & & 2.5 & 2.5 & & & \\
\hline 12/13/1999 & EM00001371 & & $\mathrm{N}$ & LR1 & EPA300.0 & CHLORIDE & 22.1 & $M G / L$ & & 2.5 & 2.5 & & & \\
\hline \begin{tabular}{|l|}
$12 / 13 / 1999$ \\
\end{tabular} & EM00001371 & & $\mathrm{N}$ & REG & EPA300.0 & FLUORIDE & 0.5 & $M G / L$ & & 0.5 & 0.5 & U & & \\
\hline \begin{tabular}{|l|}
$12 / 13 / 1999$ \\
\end{tabular} & EM00001371 & & $\mathrm{N}$ & LR1 & EPA300.0 & FLUORIDE & 0.5 & MG/L & & 0.5 & 0.5 & $\mathrm{U}$ & & \\
\hline 12/13/1999 & EM00001372 & & $\mathrm{N}$ & & L-E10612PL & GROSS ALPHA & 0.311 & $\mathrm{pCi} / \mathrm{L}$ & 0.905 & & 1.6 & $U$ & & \\
\hline \begin{tabular}{|l|}
$12 / 13 / 1999$ \\
\end{tabular} & EM00001372 & & $N$ & & L-E10612PL & GROSS BETA & 4.47 & $\mathrm{pCi} / \mathrm{L}$ & 0.894 & & 1.31 & & & \\
\hline \begin{tabular}{|l|}
$12 / 13 / 1999$ \\
\end{tabular} & EM00001371 & & $\mathrm{N}$ & REG & SW6010B & MAGNESIUM & 7120 & UG/L & & 33.6 & & & & \\
\hline 12/13/1999 & EM00001371 & & $\mathrm{N}$ & LR1 & SW6010B & MAGNESIUM & 7470 & UG/L & & 33.6 & & & & \\
\hline \begin{tabular}{|l|}
$12 / 13 / 1999$ \\
\end{tabular} & EM00001372 & & $N$ & & L-E10601PL & PLUTONIUM-238 & -0.00129 & $\mathrm{pCi} / \mathrm{L}$ & 0.00347 & & 0.0151 & $U$ & & \\
\hline \begin{tabular}{|l|}
$12 / 13 / 1999$ \\
\end{tabular} & EM00001372 & & $\mathrm{N}$ & & L-E10601PL & PLUTONIUM-239/240 & 0.000271 & $\mathrm{pCi} / \mathrm{L}$ & 0.0064 & & 0.0172 & U & & \\
\hline \begin{tabular}{|l|}
$12 / 13 / 1999$ \\
\end{tabular} & EM00001371 & & $N$ & REG & SW6010B & POTASSIUM & 7740 & UG/L & & 576 & & & & \\
\hline \begin{tabular}{|l|}
$12 / 13 / 1999$ \\
\end{tabular} & EM00001371 & & $N$ & LR1 & SW6010B & POTASSIUM & 7920 & UG/L & & 576 & & & & \\
\hline \begin{tabular}{|l|}
$12 / 13 / 1999$ \\
\end{tabular} & EM00001372 & & $\mathrm{N}$ & & L-E10602PC & POTASSIUM-40 & 330 & $\mathrm{pCi} / \mathrm{L}$ & 243 & & 475 & $\mathrm{U}$ & & \\
\hline 12/13/1999 & EM00001371 & & $\mathrm{N}$ & REG & SW6010B & SODIUM & 48400 & UG/L & & 28.2 & & & & \\
\hline \begin{tabular}{|l|}
$12 / 13 / 1999$ \\
\end{tabular} & EM00001371 & & $N$ & LR1 & SW6010B & SODIUM & 50800 & UG/L & & 28.2 & & & & \\
\hline \begin{tabular}{|l|}
$12 / 13 / 1999$ \\
\end{tabular} & EM00001371 & & $\mathrm{N}$ & REG & EPA300.0 & SULFATE (AS SO4) & 34.5 & MG/L & & 2.5 & 2.5 & & & \\
\hline 12/13/1999 & EM00001371 & & $\mathrm{N}$ & LR1 & EPA300.0 & SULFATE (AS SO4) & 34.4 & $M G / L$ & & 2.5 & 2.5 & & & \\
\hline 12/13/1999 & EM00001371 & & $\mathrm{N}$ & REG & EPA160.1 & TOTAL DISSOLVED SOLIDS & 130 & $M G / L$ & & 5 & 5 & & & \\
\hline
\end{tabular}


Table B-1. STATION ID: USGS WATER WELL A (continued)

\begin{tabular}{|c|c|c|c|c|c|c|c|c|c|c|c|c|c|c|}
\hline $12 / 13 / 1999$ & EM00001371 & & $\mathrm{N}$ & LR1 & EPA160.1 & TOTAL DISSOLVED SOLIDS & 120 & MG/L & & 5 & 5 & & & \\
\hline $12 / 13 / 1999$ & EM00001372 & & $\mathrm{N}$ & & L-E10615PL & TRITIUM & 668 & $\mathrm{pCi} / \mathrm{L}$ & 14 & & 13.7 & & & \\
\hline $2 / 17 / 2000$ & EM00001732 & & $\mathrm{N}$ & & L-E10615PL & TRITIUM & -35.4 & $\mathrm{pCi} / \mathrm{L}$ & 5.49 & & 9.89 & U & & \\
\hline 2/20/2001 & EM00003366 & 1802 & FD & REG & EPA901.1 & ACTINIUM-228 & 29.1 & PCI/L & 27.7 & 0 & 33.5 & $\mathrm{U}$ & u & \\
\hline 2/20/2001 & EM00003367 & 1802 & GRAB & REG & EPA901.1 & ACTINIUM-228 & 7.78 & $\mathrm{PCI} / \mathrm{L}$ & 24.4 & 0 & 23 & $\mathrm{U}$ & $U$ & \\
\hline 2/20/2001 & EM00003367 & 1802 & GRAB & REG & EPA310.1 & $\begin{array}{l}\text { ALKALINITY, BICARBONATE } \\
\text { (AS CACO3) }\end{array}$ & 121 & MG/L & & 1 & 1 & & & \\
\hline 2/20/2001 & EM00003367 & 1802 & GRAB & REG & EPA310.1 & $\begin{array}{l}\text { ALKALINITY, CARBONATE } \\
\text { (AS CACO3) }\end{array}$ & 1 & $\mathrm{MG} / \mathrm{L}$ & & 1 & & $\mathrm{U}$ & U & \\
\hline 2/20/2001 & EM00003366 & 1802 & FD & REG & EPA901.1 & AMERICIUM-241 & -4.71 & $\mathrm{PCI} / \mathrm{L}$ & 17.4 & 0 & 25.3 & $U$ & U & \\
\hline 2/20/2001 & EM00003367 & 1802 & GRAB & REG & EPA901.1 & AMERICIUM-241 & 4.9 & $\mathrm{PCl} / \mathrm{L}$ & 6.19 & 0 & 9.19 & u & u & \\
\hline 2/20/2001 & EM00003366 & 1802 & FD & REG & EPA901.1 & ANTIMONY-125 & 0.727 & $\mathrm{PCI} / \mathrm{L}$ & 11.8 & 0 & 20.6 & $\mathrm{U}$ & U & \\
\hline 2/20/2001 & EM00003367 & 1802 & GRAB & REG & EPA901.1 & ANTIMONY-125 & 3.34 & $\mathrm{PCI} / \mathrm{L}$ & 9.12 & 0 & 15.6 & $\mathrm{U}$ & U & \\
\hline 2/20/2001 & EM00003367 & 1802 & GRAB & REG & EPA200.7 & CALCIUM & 20300 & UG/L & & 11.4 & & & & \\
\hline 2/20/2001 & EM00003367 & 1802 & GRAB & LR1 & EPA200.7 & CALCIUM & 19964 & UG/L & & 11.4 & & & & \\
\hline $2 / 20 / 2001$ & EM00003366 & 1802 & FD & REG & EPA901.1 & CERIUM-144 & -21.3 & $\mathrm{PCI} / \mathrm{L}$ & 26 & 0 & 41.8 & U & U & \\
\hline 2/20/2001 & EM00003367 & 1802 & GRAB & REG & EPA901.1 & CERIUM-144 & 0.482 & $\mathrm{PCI} / \mathrm{L}$ & 16.7 & 0 & 28.6 & $U$ & U & \\
\hline 2/20/2001 & EM00003366 & 1802 & FD & REG & EPA901.1 & CESIUM-134 & 1.78 & $\mathrm{PCI} / \mathrm{L}$ & 3.64 & 0 & 6.96 & U & U & \\
\hline 2/20/2001 & EM00003367 & 1802 & GRAB & REG & EPA901.1 & CESIUM-134 & 1.27 & $\mathrm{PCI} / \mathrm{L}$ & 3.69 & 0 & 5.79 & $U$ & U & \\
\hline 2/20/2001 & EM00003366 & 1802 & FD & REG & EPA901.1 & CESIUM-137 & 0.972 & $\mathrm{PCI} / \mathrm{L}$ & 4.38 & 0 & 7.77 & $U$ & $U$ & \\
\hline 2/20/2001 & EM00003367 & 1802 & GRAB & REG & EPA901.1 & CESIUM-137 & -2.49 & $\mathrm{PCI} / \mathrm{L}$ & 3.83 & 0 & 6.43 & $U$ & U & \\
\hline 2/20/2001 & EM00003367 & 1802 & GRAB & REG & EPA300.0 & CHLORIDE & 24.8 & $\mathrm{MG} / \mathrm{L}$ & & 1.2 & 1.2 & & & \\
\hline 2/20/2001 & EM00003366 & 1802 & FD & REG & EPA901.1 & COBALT-60 & -1.13 & $\mathrm{PCI} / \mathrm{L}$ & 4.5 & 0 & 7.97 & $U$ & $U$ & \\
\hline 2/20/2001 & EM00003367 & 1802 & GRAB & REG & EPA901.1 & COBALT-60 & 1.56 & $\mathrm{PCI} / \mathrm{L}$ & 3.83 & 0 & 7.26 & $U$ & U & \\
\hline 2/20/2001 & EM00003366 & 1802 & FD & REG & EPA901.1 & EUROPIUM-152 & -3.65 & $\mathrm{PCI} / \mathrm{L}$ & 11.7 & 0 & 19.9 & $U$ & U & \\
\hline 2/20/2001 & EM00003367 & 1802 & GRAB & REG & EPA901.1 & EUROPIUM-152 & -4.67 & $\mathrm{PCl} / \mathrm{L}$ & 9.99 & 0 & 14.1 & $\mathrm{U}$ & u & \\
\hline 2/20/2001 & EM00003366 & 1802 & FD & REG & EPA901.1 & EUROPIUM-154 & 0.098 & $\mathrm{PCl} / \mathrm{L}$ & 12.3 & 0 & 22.5 & $\mathrm{U}$ & $U$ & \\
\hline 2/20/2001 & EM00003367 & 1802 & GRAB & REG & EPA901.1 & EUROPIUM-154 & 8.35 & $\mathrm{PCI} / \mathrm{L}$ & 13.1 & 0 & 19.6 & $U$ & U & \\
\hline 2/20/2001 & EM00003366 & 1802 & FD & REG & EPA901.1 & EUROPIUM-155 & 3.63 & $\mathrm{PCI} / \mathrm{L}$ & 13.5 & 0 & 22.8 & $\mathrm{U}$ & $U$ & \\
\hline 2/20/2001 & EM00003367 & 1802 & GRAB & REG & EPA901.1 & EUROPIUM-155 & -4.9 & $\mathrm{PCl} / \mathrm{L}$ & 8.32 & 0 & 14 & $\mathrm{U}$ & $U$ & \\
\hline 2/20/2001 & EM00003367 & 1802 & GRAB & REG & EPA300.0 & FLUORIDE & 2.5 & $\mathrm{MG} / \mathrm{L}$ & & 2.5 & 2.5 & $U$ & U & \\
\hline 2/20/2001 & EM00003367 & 1802 & GRAB & REG & EPA900.0 & GROSS ALPHA & 0.83 & $\mathrm{PCI} / \mathrm{L}$ & 0.769 & 0 & 1.01 & $U$ & $U$ & \\
\hline
\end{tabular}


Table B-1. STATION ID: USGS WATER WELL A (continued)

\begin{tabular}{|c|c|c|c|c|c|c|c|c|c|c|c|c|c|c|}
\hline $2 / 20 / 2001$ & EM00003367 & 1802 & GRAB & REG & EPA900.0 & GROSS BETA & 6.66 & $\mathrm{PCI} / \mathrm{L}$ & 1.58 & 0 & 1.91 & & & \\
\hline $2 / 20 / 2001$ & EM00003366 & 1802 & FD & REG & EPA901.1 & LEAD-212 & 6.87 & $\mathrm{PCl} / \mathrm{L}$ & 14.3 & 0 & 11.1 & U & u & \\
\hline $2 / 20 / 2001$ & EM00003367 & 1802 & GRAB & REG & EPA901.1 & LEAD-212 & 0 & $\mathrm{PCI} / \mathrm{L}$ & 5.38 & 0 & 9.76 & $\mathrm{U}$ & $\mathrm{U}$ & \\
\hline 2/20/2001 & EM00003367 & 1802 & GRAB & REG & EPA200.7 & MAGNESIUM & 7050 & UG/L & & 5.9 & & & & \\
\hline $2 / 20 / 2001$ & EM000003367 & 1802 & GRAB & LR1 & EPA200.7 & MAGNESIUM & 6882 & UG/L & & 5.9 & & & & \\
\hline $2 / 20 / 2001$ & EM00003367 & 1802 & GRAB & REG & HASL300 & PLUTONIUM-238 & 0.0511 & $\mathrm{PCI} / \mathrm{L}$ & 0.0314 & 0 & 0.0131 & & $R$ & \\
\hline 2/20/2001 & EM00003367 & 1802 & GRAB & LR1 & HASL300 & PLUTONIUM-238 & 0.00666 & $\mathrm{PCI} / \mathrm{L}$ & 0.0141 & 0 & 0.0125 & $\mathrm{U}$ & & \\
\hline $2 / 20 / 2001$ & EM000003367 & 1802 & GRAB & REG & HASL300 & PLUTONIUM-238 & 0.0244 & $\mathrm{PCI} / \mathrm{L}$ & 0.0275 & 0 & 0.0244 & & $R$ & \\
\hline $2 / 20 / 2001$ & EM00003367 & 1802 & GRAB & REG & HASL300 & PLUTONIUM-239/240 & -0.00875 & $\mathrm{PCI} / \mathrm{L}$ & 0.0121 & 0 & 0.0419 & $\mathrm{U}$ & $\mathrm{u}$ & \\
\hline $2 / 20 / 2001$ & EM00003367 & 1802 & GRAB & LR1 & HASL300 & PLUTONIUM-239/240 & 0.0166 & $\mathrm{PCI} / \mathrm{L}$ & 0.0164 & 0 & 0.0125 & & & \\
\hline $2 / 20 / 2001$ & EM000003367 & 1802 & GRAB & REG & HASL300 & PLUTONIUM-239/240 & 0 & $\mathrm{PCI} / \mathrm{L}$ & 0.0225 & 0 & 0.062 & $\mathrm{U}$ & & \\
\hline $2 / 20 / 2001$ & EM00003367 & 1802 & GRAB & REG & EPA200.7 & POTASSIUM & 8080 & UG/L & & 20.9 & & & & \\
\hline $2 / 20 / 2001$ & EM00003367 & 1802 & GRAB & LR1 & EPA200.7 & POTASSIUM & 7924 & UG/L & & 20.9 & & & & \\
\hline $2 / 20 / 2001$ & EM000003366 & 1802 & $\mathrm{FD}$ & REG & EPA901.1 & POTASSIUM-40 & 92.1 & $\mathrm{PCI} / \mathrm{L}$ & 50.5 & 0 & 108 & $\mathrm{U}$ & $\mathrm{U}$ & \\
\hline $2 / 20 / 2001$ & EM00003367 & 1802 & GRAB & REG & EPA901.1 & POTASSIUM-40 & 38.7 & $\mathrm{PCI} / \mathrm{L}$ & 56.1 & 0 & 64.6 & $\mathrm{U}$ & U & \\
\hline 2/20/2001 & EM00003366 & 1802 & $\mathrm{FD}$ & REG & EPA901.1 & PROMETHIUM-144 & 0.881 & $\mathrm{PCI} / \mathrm{L}$ & 4.35 & 0 & 7.64 & $\mathrm{U}$ & $U$ & \\
\hline 2/20/2001 & EM00003367 & 1802 & GRAB & REG & EPA901.1 & PROMETHIUM-144 & -0.0465 & $\mathrm{PCI} / \mathrm{L}$ & 3.67 & 0 & 6.4 & $\mathrm{U}$ & $U$ & \\
\hline $2 / 20 / 2001$ & EM000003366 & 1802 & $\mathrm{FD}$ & REG & EPA901.1 & PROMETHIUM-146 & 4.22 & $\mathrm{PCI} / \mathrm{L}$ & 4.36 & 0 & 10.4 & $\mathrm{U}$ & $\mathrm{U}$ & \\
\hline 2/20/2001 & EM00003367 & 1802 & GRAB & REG & EPA901.1 & PROMETHIUM-146 & 4.42 & $\mathrm{PCI} / \mathrm{L}$ & 4.54 & 0 & 6.68 & $\mathrm{U}$ & U & \\
\hline 2/20/2001 & EM00003366 & 1802 & FD & REG & EPA901.1 & RUTHENIUM-106 & 52 & $\mathrm{PCI} / \mathrm{L}$ & 58.2 & 0 & 71.3 & $\mathrm{U}$ & $U$ & \\
\hline 2/20/2001 & EM00003367 & 1802 & GRAB & REG & EPA901.1 & RUTHENIUM-106 & 17.2 & $\mathrm{PCl} / \mathrm{L}$ & 30.4 & 0 & 55.6 & $\mathrm{U}$ & $U$ & \\
\hline 2/20/2001 & EM00003367 & 1802 & GRAB & REG & EPA200.7 & SILICON & 20400 & UG/L & & 5.6 & & & 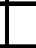 & \\
\hline 2/20/2001 & EM00003367 & 1802 & GRAB & LR1 & EPA200.7 & SILICON & 20006 & UG/L & & 5.6 & & & & \\
\hline 2/20/2001 & EM00003367 & 1802 & GRAB & REG & EPA200.7 & SODIUM & 44700 & UG/L & & 2.6 & & & & \\
\hline $2 / 20 / 2001$ & EM00003367 & 1802 & GRAB & LR1 & EPA200.7 & SODIUM & 43973 & UG/L & & 2.6 & & & & \\
\hline 2/20/2001 & EM00003367 & 1802 & GRAB & REG & EPA300.0 & SULFATE (AS SO4) & 25.4 & MG/L & & 1.2 & 1.2 & & & \\
\hline 2/20/2001 & EM00003366 & 1802 & FD & REG & EPA901.1 & THORIUM-234 & 231 & $\mathrm{PCl} / \mathrm{L}$ & 287 & 0 & 272 & $\mathrm{U}$ & $U$ & \\
\hline $2 / 20 / 2001$ & EM00003367 & 1802 & GRAB & REG & EPA901.1 & THORIUM-234 & 79.7 & $\mathrm{PCI} / \mathrm{L}$ & 127 & 0 & 132 & $\mathrm{U}$ & $\mathrm{U}$ & \\
\hline 2/20/2001 & EM00003367 & 1802 & GRAB & REG & EPA160.1 & TOTAL DISSOLVED SOLIDS & 252 & $\mathrm{MG} / \mathrm{L}$ & & 5 & 5 & & $\mathrm{~J}$ & \\
\hline $2 / 20 / 2001$ & EM00003367 & 1802 & GRAB & LR1 & EPA160.1 & TOTAL DISSOLVED SOLIDS & 239 & $M G / L$ & & 5 & 5 & & . & \\
\hline
\end{tabular}

B-3 
Table B-1. STATION ID: USGS WATER WELL A (continued)

\begin{tabular}{|c|c|c|c|c|c|c|c|c|c|c|c|c|c|c|}
\hline $2 / 20 / 2001$ & EM00003366 & 1802 & FD & REG & EPA906.0 & TRITIUM & 11400 & $\mathrm{PCl} / \mathrm{L}$ & 436 & 0 & 223 & & & \\
\hline $2 / 20 / 2001$ & EM00003367 & 1802 & GRAB & REG & EPA906.0 & TRITIUM & 12100 & $\mathrm{PCl} / \mathrm{L}$ & 454 & 0 & 226 & & & \\
\hline $2 / 20 / 2001$ & EM00003365 & 1802 & EB & REG & EPA906.0 & TRITIUM & 463 & $\mathrm{PCI} / \mathrm{L}$ & 171 & 0 & 259 & & & \\
\hline 2/20/2001 & EM00003366 & 1802 & FD & REG & EPA901.1 & URANIUM-235 & 22.2 & $\mathrm{PCI} / \mathrm{L}$ & 26.9 & 0 & 46 & $\mathrm{U}$ & $U$ & \\
\hline $2 / 20 / 2001$ & EM000003367 & 1802 & GRAB & REG & EPA901.1 & URANIUM-235 & 22.5 & $\mathrm{PCI} / \mathrm{L}$ & 18.5 & 0 & 32.8 & $\mathrm{U}$ & $\mathrm{U}$ & \\
\hline $2 / 20 / 2001$ & EM00003366 & 1802 & FD & REG & EPA901.1 & URANIUM-238 & 0 & $\mathrm{PCI} / \mathrm{L}$ & 287 & 0 & 214 & $\mathrm{U}$ & $\mathrm{U}$ & \\
\hline $2 / 20 / 2001$ & EM00003367 & 1802 & GRAB & REG & EPA901.1 & URANIUM-238 & 79.7 & $\mathrm{PCI} / \mathrm{L}$ & 127 & 0 & 89.3 & $\mathrm{U}$ & $\mathrm{U}$ & \\
\hline $2 / 20 / 2001$ & EM000003366 & 1802 & FD & REG & EPA901.1 & YTTRIUM-88 & -1.8 & $\mathrm{PCl} / \mathrm{L}$ & 4.37 & 0 & 7.62 & $\mathrm{U}$ & $\mathrm{U}$ & \\
\hline $2 / 20 / 2001$ & EM000003367 & 1802 & GRAB & REG & EPA901.1 & YTTRIUM-88 & 1.09 & $\mathrm{PCl} / \mathrm{L}$ & 5.54 & 0 & 6.29 & $\mathrm{U}$ & $\mathrm{U}$ & \\
\hline $1 / 16 / 2002$ & EM00004617 & 1798 & GRAB & REG & EPA906.0 & CARBON-14 & -290 & $\mathrm{pCi} / \mathrm{L}$ & 118 & & 187 & $\mathrm{U}$ & $\mathrm{U}$ & \\
\hline $1 / 16 / 2002$ & EM00004617 & 1798 & GRAB & DUP & EPA906.0 & CARBON-14 & -326 & $\mathrm{pCi} / \mathrm{L}$ & 119 & & 187 & U & & \\
\hline $1 / 16 / 2002$ & EM00004616 & 1798 & FD & REG & DOE RP550 & TECHNETIUM-99 & -2.62 & $\mathrm{pCi} / \mathrm{L}$ & 1.73 & & 5.92 & $U$ & $\mathrm{U}$ & \\
\hline $1 / 16 / 2002$ & EM00004617 & 1798 & GRAB & REG & DOE RP550 & TECHNETIUM-99 & -0.971 & $\mathrm{pCi} / \mathrm{L}$ & 1.8 & & 6.15 & $\mathrm{U}$ & $\mathrm{U}$ & \\
\hline $1 / 16 / 2002$ & EM00004615 & & EB & REG & EPA906.0 & TRITIUM & -8.72 & $\mathrm{PCI} / \mathrm{L}$ & 130 & & 225 & $\mathrm{U}$ & $\mathrm{U}$ & \\
\hline $1 / 16 / 2002$ & EM00004617 & 1798 & GRAB & REG & EPA906.0 & TRITIUM & 6600 & $\mathrm{PCI} / \mathrm{L}$ & 336 & & 225 & & & \\
\hline $1 / 29 / 2003$ & EM00006035 & 1798 & GRAB & REG & EPA901.1 & ACTINIUM-228 & -10.8 & $\mathrm{pCi} / \mathrm{L}$ & 25.6 & & 45 & $\mathrm{U}$ & U & \\
\hline $1 / 29 / 2003$ & EM00006035 & 1798 & GRAB & REG & EPA901.1 & AMERICIUM-241 & -5.89 & $\mathrm{pCi} / \mathrm{L}$ & 25.3 & & 43.4 & $\mathrm{U}$ & $\mathrm{U}$ & \\
\hline $1 / 29 / 2003$ & EM00006035 & 1798 & GRAB & REG & EPA901.1 & ANTIMONY-125 & -9.26 & $\mathrm{pCi} / \mathrm{L}$ & 10.8 & & 19.5 & $\mathrm{U}$ & $\mathrm{U}$ & \\
\hline $1 / 29 / 2003$ & EM00006035 & 1798 & GRAB & REG & SM2320B & BICARBONATE & 130 & MG/L & & 2 & 2 & & 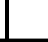 & \\
\hline $1 / 29 / 2003$ & EM00006035 & 1798 & GRAB & REG & EPA200.7 & CALCIUM & 18000 & UG/L & & 10.2 & 10.2 & & & \\
\hline $1 / 29 / 2003$ & EM00006035 & 1798 & GRAB & REG & EERF C01 & CARBON-14 & -77 & $\mathrm{pCi} / \mathrm{L}$ & 110 & & 183 & $\mathrm{U}$ & $U$ & \\
\hline $1 / 29 / 2003$ & EM00006035 & 1798 & GRAB & DUP & EERF C01 & CARBON-14 & -61.1 & $\mathrm{pCi} / \mathrm{L}$ & 110 & & 183 & $\mathrm{U}$ & $\mathrm{U}$ & \\
\hline 1/29/2003 & EM00006035 & 1798 & GRAB & REG & SM2320B & CARBONATE (AS CO3) & 2 & MG/L & & 2 & 2 & $\mathrm{U}$ & $\mathrm{U}$ & \\
\hline $1 / 29 / 2003$ & EM00006035 & 1798 & GRAB & REG & EPA901.1 & CERIUM-144 & -15.1 & $\mathrm{pCi} / \mathrm{L}$ & 20.3 & & 35.5 & $\mathrm{U}$ & $U$ & \\
\hline $1 / 29 / 2003$ & EM00006035 & 1798 & GRAB & REG & EPA901.1 & CESIUM-134 & -2.51 & $\mathrm{pCi} / \mathrm{L}$ & 6.69 & & 11.7 & $\mathrm{U}$ & $\mathrm{U}$ & \\
\hline $1 / 29 / 2003$ & EM00006035 & 1798 & GRAB & REG & EPA901.1 & CESIUM-137 & -0.17 & $\mathrm{pCi} / \mathrm{L}$ & 4.5 & & 7.89 & $\mathrm{U}$ & $U$ & \\
\hline $1 / 29 / 2003$ & EM00006035 & 1798 & GRAB & REG & EPA300.0 & CHLORIDE & 25.1 & MG/L & & 0.25 & 0.25 & & . & \\
\hline $1 / 29 / 2003$ & EM00006035 & 1798 & GRAB & REG & EPA901.1 & COBALT-60 & 0.981 & $\mathrm{pCi} / \mathrm{L}$ & 4.85 & & 8.49 & $\mathrm{U}$ & $\mathrm{U}$ & \\
\hline $1 / 29 / 2003$ & EM00006035 & 1798 & GRAB & REG & EPA901.1 & EUROPIUM-152 & -7.19 & $\mathrm{pCi} / \mathrm{L}$ & 24.8 & & 45.4 & $\mathrm{U}$ & $U$ & \\
\hline $1 / 29 / 2003$ & EM00006035 & 1798 & GRAB & REG & EPA901.1 & EUROPIUM-154 & 5.64 & $\mathrm{pCi} / \mathrm{L}$ & 27.2 & & 47 & $\mathrm{U}$ & $\mathrm{U}$ & \\
\hline
\end{tabular}


Table B-1. STATION ID: USGS WATER WELL A (continued)

\begin{tabular}{|c|c|c|c|c|c|c|c|c|c|c|c|c|c|c|}
\hline $1 / 29 / 2003$ & EM00006035 & 1798 & GRAB & REG & EPA901.1 & EUROPIUM-155 & -4.7 & $\mathrm{pCi} / \mathrm{L}$ & 11.6 & & 20.1 & $\mathrm{U}$ & $\mathrm{U}$ & \\
\hline $1 / 29 / 2003$ & EM00006035 & 1798 & GRAB & REG & EPA300.0 & FLUORIDE & 0.38 & MG/L & & 0.25 & 0.25 & & & \\
\hline $1 / 29 / 2003$ & EM00006035 & 1798 & GRAB & REG & EPA900.0 & GROSS ALPHA & 0.47 & $\mathrm{pCi} / \mathrm{L}$ & 0.661 & & 1.11 & U & |u & \\
\hline $1 / 29 / 2003$ & EM00006035 & 1798 & GRAB & DUP & EPA900.0 & GROSS ALPHA & 1.03 & $\mathrm{pCi} / \mathrm{L}$ & 0.817 & & 1.3 & $\mathrm{U}$ & u & \\
\hline $1 / 29 / 2003$ & EM00006035 & 1798 & GRAB & REG & EPA900.0 & GROSS BETA & 6.9 & $\mathrm{pCi} / \mathrm{L}$ & 1.63 & & 2.01 & & & \\
\hline $1 / 29 / 2003$ & EM00006035 & 1798 & GRAB & DUP & EPA900.0 & GROSS BETA & 5.72 & $\mathrm{pCi} / \mathrm{L}$ & 1.57 & & 2.12 & & & \\
\hline $1 / 29 / 2003$ & EM00006035 & 1798 & GRAB & REG & EPA901.1 & LEAD-212 & 1.81 & $\mathrm{pCi} / \mathrm{L}$ & 8.53 & & 14.3 & U & U & \\
\hline $1 / 29 / 2003$ & EM00006035 & 1798 & GRAB & REG & EPA200.7 & MAGNESIUM & 5850 & UG/L & & 23.9 & 23.9 & & & \\
\hline $1 / 29 / 2003$ & EM00006035 & 1798 & GRAB & REG & ASTMD3972-90M & PLUTONIUM-238 & 0 & $\mathrm{pCi} / \mathrm{L}$ & 0.0223 & & 0.0169 & U & |u & \\
\hline $1 / 29 / 2003$ & EM00006035 & 1798 & GRAB & DUP & ASTMD3972-90M & PLUTONIUM-238 & 0.0117 & $\mathrm{pCi} / \mathrm{L}$ & 0.0179 & & 0.0338 & U & u & \\
\hline $1 / 29 / 2003$ & EM00006035 & 1798 & GRAB & REG & ASTMD3972-90M & PLUTONIUM-239/240 & -0.00674 & $\mathrm{pCi} / \mathrm{L}$ & 0.0223 & & 0.0455 & $\mathrm{U}$ & $\mathrm{U}$ & \\
\hline $1 / 29 / 2003$ & EM00006035 & 1798 & GRAB & DUP & ASTMD3972-90M & PLUTONIUM-239/240 & 0.00418 & $\mathrm{pCi} / \mathrm{L}$ & 0.0165 & & 0.0125 & U & |u & \\
\hline $1 / 29 / 2003$ & EM00006035 & 1798 & GRAB & REG & EPA200.7 & POTASSIUM & 6860 & UG/L & & 422 & 422 & & & \\
\hline $1 / 29 / 2003$ & EM00006035 & 1798 & GRAB & REG & EPA901.1 & POTASSIUM-40 & 5.37 & $\mathrm{pCi} / \mathrm{L}$ & 85.2 & & 147 & $\mathrm{U}$ & $\mathrm{U}$ & \\
\hline $1 / 29 / 2003$ & EM00006035 & 1798 & GRAB & REG & EPA901.1 & PROMETHIUM-144 & -2.19 & $\mathrm{pCi} / \mathrm{L}$ & 4.94 & & 8.75 & $\mathrm{U}$ & |u & \\
\hline $1 / 29 / 2003$ & EM00006035 & 1798 & GRAB & REG & EPA901.1 & PROMETHIUM-146 & 0.805 & $\mathrm{pCi} / \mathrm{L}$ & 5.85 & & 9.99 & U & u & \\
\hline $1 / 29 / 2003$ & EM00006035 & 1798 & GRAB & REG & EPA901.1 & RUTHENIUM-106 & 18.7 & $\mathrm{pCi} / \mathrm{L}$ & 44 & & 74.1 & $\mathrm{U}$ & $\mathrm{U}$ & \\
\hline $1 / 29 / 2003$ & EM00006035 & 1798 & GRAB & REG & EPA200.7 & SILICON & 11700 & UG/L & & 7.3 & 7.3 & & & \\
\hline $1 / 29 / 2003$ & EM00006035 & 1798 & GRAB & REG & EPA200.7 & SODIUM & 46500 & UG/L & & 17.6 & 17.6 & & & \\
\hline $1 / 29 / 2003$ & EM00006035 & 1798 & GRAB & REG & EPA300.0 & SULFATE (AS SO4) & 16.9 & MG/L & & 0.5 & 0.5 & & & \\
\hline $1 / 29 / 2003$ & EM00006035 & 1798 & GRAB & REG & DOE RP550 & TECHNITIUM-99 & 2.3 & $\mathrm{pCi} / \mathrm{L}$ & 3.99 & & 6.56 & $\mathrm{U}$ & $\mathrm{U}$ & \\
\hline $1 / 29 / 2003$ & EM00006035 & 1798 & GRAB & REG & EPA901.1 & THORIUM-234 & 59.5 & $\mathrm{pCi} / \mathrm{L}$ & 92.8 & & 153 & $\mathrm{U}$ & $\mathrm{U}$ & \\
\hline $1 / 29 / 2003$ & EM00006035 & 1798 & GRAB & REG & EPA160.1 & TOTAL DISSOLVED SOLIDS & 231 & $M G / L$ & & 5 & 5 & & . & \\
\hline $1 / 29 / 2003$ & EM00006035 & 1798 & GRAB & REG & EPA906.0 & TRITIUM & 569 & $\mathrm{pCi} / \mathrm{L}$ & 258 & & 385 & & & \\
\hline $1 / 29 / 2003$ & EM00006035 & 1798 & GRAB & DUP & EPA906.0 & TRITIUM & 478 & $\mathrm{pCi} / \mathrm{L}$ & 251 & & 385 & & & \\
\hline $1 / 29 / 2003$ & EM00006033 & & EB & REG & EPA906.0 & TRITIUM & -34.3 & $\mathrm{PCI} / \mathrm{L}$ & 156 & & 270 & $\mathrm{U}$ & $\mathrm{U}$ & \\
\hline $1 / 29 / 2003$ & EM00006035 & 1798 & GRAB & REG & EPA906.0 & TRITIUM & 7200 & $\mathrm{PCI} / \mathrm{L}$ & 367 & & 270 & & & \\
\hline $1 / 29 / 2003$ & EM00006035 & 1798 & GRAB & REG & EPA901.1 & URANIUM-235 & 0.643 & $\mathrm{pCi} / \mathrm{L}$ & 29.9 & & 50.3 & $\mathrm{U}$ & $\mathrm{U}$ & \\
\hline $1 / 29 / 2003$ & EM00006035 & 1798 & GRAB & REG & EPA901.1 & YTTRIUM-88 & 0.979 & $\mathrm{pCi} / \mathrm{L}$ & 8.03 & & 13.7 & $\mathrm{U}$ & $\mathrm{U}$ & \\
\hline $2 / 3 / 2004$ & EM00007332 & 1798 & GRAB & DUP & EPA901.1 & ACTINIUM-228 & 15.2 & $\mathrm{pCi} / \mathrm{L}$ & 20.4 & & 33.5 & U & |u & \\
\hline $2 / 3 / 2004$ & EM00007332 & 1798 & GRAB & REG & EPA901.1 & ACTINIUM-228 & 26.8 & $\mathrm{pCi} / \mathrm{L}$ & 18.9 & & 28.9 & U & U & \\
\hline
\end{tabular}


Table B-1. STATION ID: USGS WATER WELL A (continued)

\begin{tabular}{|c|c|c|c|c|c|c|c|c|c|c|c|c|c|c|}
\hline 2/3/2004 & EM00007332 & 1798 & GRAB & REG & SM2320B & $\begin{array}{l}\text { ALKALINITY, BICARBONATE } \\
\text { (AS CACO3) }\end{array}$ & 146 & MG/L & & 2 & 2 & & & \\
\hline 2/3/2004 & EM00007332 & 1798 & GRAB & REG & SM2320B & $\begin{array}{l}\text { ALKALINITY, CARBOTNATE } \\
\text { (AS CACO3) }\end{array}$ & 2 & MG/L & & 2 & & $u$ & $\mathrm{U}$ & \\
\hline $2 / 3 / 2004$ & EM000007332 & 1798 & GRAB & DUP & EPA901.1 & AMERICIUM-241 & 1.35 & $\mathrm{pCi} / \mathrm{L}$ & 4.35 & & 7.28 & $U$ & $U$ & \\
\hline $2 / 3 / 2004$ & EM00007332 & 1798 & GRAB & REG & EPA901.1 & AMERICIUM-241 & -0.266 & $\mathrm{pCi} / \mathrm{L}$ & 23.8 & & 40.5 & $\mathrm{U}$ & $\mathrm{U}$ & \\
\hline $2 / 3 / 2004$ & EM00007332 & 1798 & GRAB & REG & EPA901.1 & ANTIMONY-125 & 2.24 & $\mathrm{pCi} / \mathrm{L}$ & 11.1 & & 19.8 & $U$ & $\mathrm{U}$ & \\
\hline $2 / 3 / 2004$ & EM000007332 & 1798 & GRAB & DUP & EPA901.1 & ANTIMONY-125 & -2.88 & $\mathrm{pCi} / \mathrm{L}$ & 8.48 & & 14.8 & $U$ & $U$ & \\
\hline $2 / 3 / 2004$ & EM00007332 & 1798 & GRAB & DUP & EPA901.1 & BISMUTH-214 & 15 & $\mathrm{pCi} / \mathrm{L}$ & 8.34 & & 12.7 & $\mathrm{JN}$ & $\mathrm{J}$ & 14 \\
\hline $2 / 3 / 2004$ & EM00007332 & 1798 & GRAB & REG & EPA200.7 & CALCIUM & 17700 & UG/L & & 14.9 & 14.9 & & & \\
\hline $2 / 3 / 2004$ & EM00007332 & 1798 & GRAB & LR1 & EPA200.7 & CALCIUM & 17653 & UG/L & & 14.9 & 14.9 & & & \\
\hline $2 / 3 / 2004$ & EM00007332 & 1798 & GRAB & DUP & EPA901.1 & CERIUM-144 & 2.89 & $\mathrm{pCi} / \mathrm{L}$ & 13.3 & & 22.4 & $U$ & $U$ & \\
\hline $2 / 3 / 2004$ & EM00007332 & 1798 & GRAB & REG & EPA901.1 & CERIUM-144 & 11.4 & $\mathrm{pCi} / \mathrm{L}$ & 21.2 & & 35.2 & $U$ & $\mathrm{U}$ & \\
\hline $2 / 3 / 2004$ & EM00007332 & 1798 & GRAB & REG & EPA901.1 & CESIUM-134 & 0.122 & $\mathrm{pCi} / \mathrm{L}$ & 5.07 & & 8.71 & $U$ & $\mathrm{U}$ & \\
\hline $2 / 3 / 2004$ & EM00007332 & 1798 & GRAB & DUP & EPA901.1 & CESIUM-134 & -3.63 & $\mathrm{pCi} / \mathrm{L}$ & 3.91 & & 6.91 & $U$ & $\mathrm{U}$ & \\
\hline $2 / 3 / 2004$ & EM00007332 & 1798 & GRAB & REG & EPA901.1 & CESIUM-137 & -4.38 & $\mathrm{pCi} / \mathrm{L}$ & 4.44 & & 8.26 & $U$ & $\mathrm{U}$ & \\
\hline $2 / 3 / 2004$ & EM000007332 & 1798 & GRAB & DUP & EPA901.1 & CESIUM-137 & 0.803 & $\mathrm{pCi} / \mathrm{L}$ & 3.53 & & 6.02 & U & $\mathrm{U}$ & \\
\hline $2 / 3 / 2004$ & EM00007332 & 1798 & GRAB & REG & EPA300.0 & CHLORIDE & 22.9 & MG/L & & 1.2 & 1.2 & & & \\
\hline $2 / 3 / 2004$ & EM000007332 & 1798 & GRAB & DUP & EPA901.1 & COBALT-60 & -1.8 & $\mathrm{pCi} / \mathrm{L}$ & 4.42 & & 7.98 & $U$ & $\mathrm{U}$ & \\
\hline $2 / 3 / 2004$ & EM00007332 & 1798 & GRAB & REG & EPA901.1 & COBALT-60 & -1.11 & $\mathrm{pCi} / \mathrm{L}$ & 5.47 & & 9.86 & U & $U$ & \\
\hline $2 / 3 / 2004$ & EM00007332 & 1798 & GRAB & REG & EPA901.1 & EUROPIUM-152 & 12.8 & $\mathrm{pCi} / \mathrm{L}$ & 27.6 & & 46.7 & $U$ & $\mathrm{U}$ & \\
\hline $2 / 3 / 2004$ & EM00007332 & 1798 & GRAB & DUP & EPA901.1 & EUROPIUM-152 & -0.291 & $\mathrm{pCi} / \mathrm{L}$ & 19.6 & & 34.6 & $U$ & $\mathrm{U}$ & \\
\hline $2 / 3 / 2004$ & EM000007332 & 1798 & GRAB & REG & EPA901.1 & EUROPIUM-154 & -13.4 & $\mathrm{pCi} / \mathrm{L}$ & 26.8 & & 48.9 & $\mathrm{U}$ & $\mathrm{U}$ & \\
\hline $2 / 3 / 2004$ & EM00007332 & 1798 & GRAB & DUP & EPA901.1 & EUROPIUM-154 & -7.21 & $\mathrm{pCi} / \mathrm{L}$ & 19.8 & & 35.5 & $U$ & $\mathrm{U}$ & \\
\hline $2 / 3 / 2004$ & EM00007332 & 1798 & GRAB & REG & EPA901.1 & EUROPIUM-155 & -5.15 & $\mathrm{pCi} / \mathrm{L}$ & 13.9 & & 23.8 & $U$ & $\mathrm{U}$ & \\
\hline $2 / 3 / 2004$ & EM00007332 & 1798 & GRAB & DUP & EPA901.1 & EUROPIUM-155 & 0.352 & $\mathrm{pCi} / \mathrm{L}$ & 6.15 & & 10.4 & U & $\mathrm{U}$ & \\
\hline $2 / 3 / 2004$ & EM000007332 & 1798 & GRAB & REG & EPA300.0 & FLUORIDE & 0.42 & MG/L & & 0.25 & 0.25 & & & \\
\hline $2 / 3 / 2004$ & EM00007332 & 1798 & GRAB & REG & EPA900.0 & GROSS ALPHA & 0.926 & $\mathrm{pCi} / \mathrm{L}$ & 0.677 & & 1.2 & $U$ & $\mathrm{U}$ & \\
\hline $2 / 3 / 2004$ & EM00007332 & 1798 & GRAB & DUP & EPA900.0 & GROSS ALPHA & 1.43 & pCi/L & 0.691 & & 1.05 & $B$ & & \\
\hline $2 / 3 / 2004$ & EM00007332 & 1798 & GRAB & DUP & EPA900.0 & GROSS BETA & 7.61 & $\mathrm{pCi} / \mathrm{L}$ & 1.7 & & 1.99 & & & \\
\hline $2 / 3 / 2004$ & EM00007332 & 1798 & GRAB & REG & EPA900.0 & GROSS BETA & 7.04 & $\mathrm{pCi} / \mathrm{L}$ & 1.56 & & 1.73 & & & \\
\hline
\end{tabular}


Table B-1. STATION ID: USGS WATER WELL A (continued)

\begin{tabular}{|c|c|c|c|c|c|c|c|c|c|c|c|c|c|c|}
\hline $2 / 3 / 2004$ & EM00007332 & 1798 & GRAB & REG & EPA901.1 & LEAD-212 & -3.04 & $\mathrm{pCi} / \mathrm{L}$ & 10.3 & & 17.5 & & $\mathrm{U}$ & \\
\hline $2 / 3 / 2004$ & EM00007332 & 1798 & GRAB & DUP & EPA901.1 & LEAD-212 & -3.99 & $\mathrm{pCi} / \mathrm{L}$ & 7.33 & & 12.5 & $\mathrm{U}$ & $\mathrm{U}$ & \\
\hline $2 / 3 / 2004$ & EM000007332 & 1798 & GRAB & REG & EPA200.7 & MAGNESIUM & 5600 & UG/L & & 28.8 & 28.8 & & & \\
\hline $2 / 3 / 2004$ & EM00007332 & 1798 & GRAB & LR1 & EPA200.7 & MAGNESIUM & 5631 & UG/L & & 28.8 & 28.8 & & & \\
\hline $2 / 3 / 2004$ & EM00007332 & 1798 & GRAB & REG & ASTMD3972-90M & PLUTONIUM-238 & 0 & $\mathrm{pCi} / \mathrm{L}$ & 0.0263 & & 0.0197 & $\mathrm{U}$ & $\mathrm{U}$ & \\
\hline $2 / 3 / 2004$ & EM00007332 & 1798 & GRAB & REG & ASTMD3972-90M & PLUTONIUM-239/240 & 0 & $\mathrm{pCi} / \mathrm{L}$ & 0.0263 & & 0.0197 & U & |u & \\
\hline $2 / 3 / 2004$ & EM00007332 & 1798 & GRAB & REG & EPA200.7 & POTASSIUM & 6840 & UG/L & & 513 & 513 & & & \\
\hline $2 / 3 / 2004$ & EM00007332 & 1798 & GRAB & LR1 & EPA200.7 & POTASSIUM & 6692 & UG/L & & 513 & 513 & & & \\
\hline $2 / 3 / 2004$ & EM000007332 & 1798 & GRAB & DUP & EPA901.1 & POTASSIUM-40 & 13.8 & $\mathrm{pCi} / \mathrm{L}$ & 73.1 & & 124 & $\mathrm{U}$ & $\mathrm{U}$ & \\
\hline $2 / 3 / 2004$ & EM00007332 & 1798 & GRAB & REG & EPA901.1 & POTASSIUM-40 & 98.6 & $\mathrm{pCi} / \mathrm{L}$ & 105 & & 170 & $\mathrm{U}$ & $\mathrm{U}$ & \\
\hline $2 / 3 / 2004$ & EM00007332 & 1798 & GRAB & REG & EPA901.1 & PROMETHIUM-144 & -1.1 & pCi/L & 4.92 & & 8.63 & $\mathrm{U}$ & $\mathrm{U}$ & \\
\hline $2 / 3 / 2004$ & EM000007332 & 1798 & GRAB & DUP & EPA901.1 & PROMETHIUM-144 & -0.723 & $\mathrm{pCi} / \mathrm{L}$ & 4.13 & & 7.13 & $\mathrm{U}$ & $\mathrm{U}$ & \\
\hline $2 / 3 / 2004$ & EM00007332 & 1798 & GRAB & REG & EPA901.1 & PROMETHIUM-146 & 0.992 & $\mathrm{pCi} / \mathrm{L}$ & 5.14 & & 8.8 & $\mathrm{U}$ & $\mathrm{U}$ & \\
\hline $2 / 3 / 2004$ & EM00007332 & 1798 & GRAB & DUP & EPA901.1 & PROMETHIUM-146 & 0.213 & $\mathrm{pCi} / \mathrm{L}$ & 3.87 & & 6.64 & $\mathrm{U}$ & $\mathrm{U}$ & \\
\hline $2 / 3 / 2004$ & EM000007332 & 1798 & GRAB & REG & EPA901.1 & RUTHENIUM-106 & -14.3 & $\mathrm{pCi} / \mathrm{L}$ & 40.6 & & 72.3 & $\mathrm{U}$ & $\mathrm{U}$ & \\
\hline $2 / 3 / 2004$ & EM00007332 & 1798 & GRAB & DUP & EPA901.1 & RUTHENIUM-106 & -12.4 & $\mathrm{pCi} / \mathrm{L}$ & 35.5 & & 62 & $\mathrm{U}$ & $\mathrm{U}$ & \\
\hline $2 / 3 / 2004$ & EM00007332 & 1798 & GRAB & REG & EPA200.7 & SILICON & 10600 & UG/L & & 8.3 & 8.3 & & & \\
\hline $2 / 3 / 2004$ & EM000007332 & 1798 & GRAB & LR1 & EPA200.7 & SILICON & 10563 & UG/L & & 8.3 & 8.3 & & & \\
\hline $2 / 3 / 2004$ & EM00007332 & 1798 & GRAB & REG & EPA200.7 & SODIUM & 49100 & UG/L & & 30.2 & 30.2 & & | & \\
\hline $2 / 3 / 2004$ & EM00007332 & 1798 & GRAB & LR1 & EPA200.7 & SODIUM & 49360 & UG/L & & 30.2 & 30.2 & & & \\
\hline $2 / 3 / 2004$ & EM000007332 & 1798 & GRAB & REG & EPA300.0 & SULFATE (AS SO4) & 9.7 & MG/L & & 1.2 & 1.2 & & & \\
\hline $2 / 3 / 2004$ & EM00007332 & 1798 & GRAB & REG & EPA901.1 & THORIUM-234 & -31.3 & $\mathrm{pCi} / \mathrm{L}$ & 84.6 & & 144 & $\mathrm{U}$ & $\mathrm{U}$ & \\
\hline $2 / 3 / 2004$ & EM00007332 & 1798 & GRAB & DUP & EPA901.1 & THORIUM-234 & -9.68 & $\mathrm{pCi} / \mathrm{L}$ & 48.8 & & 81.9 & $\mathrm{U}$ & $\mathrm{U}$ & \\
\hline $2 / 3 / 2004$ & EM000007332 & 1798 & GRAB & REG & EPA160.1 & TOTAL DISSOLVED SOLIDS & 186 & MG/L & & 5 & 5 & & & \\
\hline $2 / 3 / 2004$ & EM00007331 & 1798 & FD & REG & EPA906.0 & TRITIUM & 5490 & $\mathrm{PCI} / \mathrm{L}$ & 309 & & 235 & & $\mathrm{~J}$ & \\
\hline $2 / 3 / 2004$ & EM00007332 & 1798 & GRAB & REG & EPA906.0 & TRITIUM & 5410 & $\mathrm{PCI} / \mathrm{L}$ & 304 & & 230 & & $\mathrm{~J}$ & \\
\hline $2 / 3 / 2004$ & EM000007332 & 1798 & GRAB & DUP & EPA901.1 & URANIUM-235 & 15.3 & $\mathrm{pCi} / \mathrm{L}$ & 18.2 & & 29.8 & $\mathrm{U}$ & $\mathrm{U}$ & \\
\hline $2 / 3 / 2004$ & EM00007332 & 1798 & GRAB & REG & EPA901.1 & URANIUM-235 & -2.16 & $\mathrm{pCi} / \mathrm{L}$ & 24 & & 40.8 & $\mathrm{U}$ & $\mathrm{U}$ & \\
\hline $2 / 3 / 2004$ & EM00007332 & 1798 & GRAB & DUP & EPA901.1 & YTTRIUM-88 & 2.37 & $\mathrm{pCi} / \mathrm{L}$ & 4.82 & & 8.07 & $\mathrm{U}$ & $\mathrm{U}$ & \\
\hline $2 / 3 / 2004$ & EM000007332 & 1798 & GRAB & REG & EPA901.1 & YTTRIUM-88 & -0.704 & $\mathrm{pCi} / \mathrm{L}$ & 8.64 & & 14.9 & $\mathrm{U}$ & $\mathrm{U}$ & \\
\hline $2 / 8 / 2005$ & EM00008643 & 1798 & GRAB & REG & EPA901.1 & ACTINIUM-228 & 18.2 & $\mathrm{PCl} / \mathrm{L}$ & 14.6 & 0 & 29.4 & U & U & \\
\hline
\end{tabular}


Table B-1. STATION ID: USGS WATER WELL A (continued)

\begin{tabular}{|c|c|c|c|c|c|c|c|c|c|c|c|c|c|}
\hline $2 / 8 / 2005$ & EM00008643 & 1798 & GRAB & REG & SM2320B & $\begin{array}{l}\text { ALKALINITY, BICARBONATE } \\
\text { (AS CACO3) }\end{array}$ & 161 & MG/L & & 2 & 0.5 & & \\
\hline 2/8/2005 & EM00008643 & 1798 & GRAB & REG & SM2320B & $\begin{array}{l}\text { ALKALINITY, CARBONATE } \\
\text { (AS CACO3) }\end{array}$ & & MG/L & & 2 & 0.5 & $u$ & $u$ \\
\hline $2 / 8 / 2005$ & EM00008643 & 1798 & GRAB & REG & EPA901.1 & AMERICIUM-241 & -3.84 & $\mathrm{PCI} / \mathrm{L}$ & 25.5 & 0 & 38.8 & $U$ & $\mathrm{U}$ \\
\hline $2 / 8 / 2005$ & EM00008643 & 1798 & GRAB & REG & EPA901.1 & ANTIMONY-125 & 2.65 & $\mathrm{PCI} / \mathrm{L}$ & \begin{tabular}{l|l}
9.7 \\
\end{tabular} & 0 & 18 & U & U \\
\hline $2 / 8 / 2005$ & EM00008643 & 1798 & GRAB & REG & EPA200.7 & CALCIUM & 19500 & UG/L & & 46.8 & 7.8 & & \\
\hline $2 / 8 / 2005$ & EM00008643 & 1798 & GRAB & REG & EERF C01 & CARBON-14 & -70.6 & $\mathrm{PCI} / \mathrm{L}$ & 107 & 0 & 187 & $U$ & U \\
\hline $2 / 8 / 2005$ & EM00008643 & 1798 & GRAB & REG & EPA901.1 & CERIUM-144 & 2.33 & $\mathrm{PCI} / \mathrm{L}$ & 21.4 & 0 & 38.3 & $U$ & $\mathrm{U}$ \\
\hline $2 / 8 / 2005$ & EM00008643 & 1798 & GRAB & REG & EPA901.1 & CESIUM-134 & 1.18 & $\mathrm{PCI} / \mathrm{L}$ & 3.86 & 0 & 7.23 & $u$ & $u$ \\
\hline $2 / 8 / 2005$ & EM00008643 & 1798 & GRAB & REG & EPA901.1 & CESIUM-137 & 1.15 & $\mathrm{PCI} / \mathrm{L}$ & 3.7 & 0 & 6.24 & $U$ & U \\
\hline $2 / 8 / 2005$ & EM00008643 & 1798 & GRAB & REG & EPA300.0 & CHLORIDE & 21.8 & MG/L & & 2.5 & 0.25 & & \\
\hline $2 / 8 / 2005$ & EM00008643 & 1798 & GRAB & REG & EPA901.1 & COBALT-60 & 1.31 & $\mathrm{PCI} / \mathrm{L}$ & 3.65 & 0 & 6.72 & $U$ & 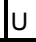 \\
\hline $2 / 8 / 2005$ & EM00008643 & 1798 & GRAB & REG & EPA901.1 & EUROPIUM-152 & -0.308 & $\mathrm{PCI} / \mathrm{L}$ & 10.7 & 0 & 18.2 & $U$ & $\mathrm{U}$ \\
\hline $2 / 8 / 2005$ & EM00008643 & 1798 & GRAB & REG & EPA901.1 & EUROPIUM-154 & -1.92 & $\mathrm{PCI} / \mathrm{L}$ & 9.01 & 0 & 16.7 & U & U \\
\hline $2 / 8 / 2005$ & EM00008643 & 1798 & GRAB & REG & EPA901.1 & EUROPIUM-155 & -0.996 & $\mathrm{PCI} / \mathrm{L}$ & 11.4 & 0 & 20.3 & $U$ & $U$ \\
\hline 2/8/2005 & EM00008643 & 1798 & GRAB & REG & EPA300.0 & FLUORIDE & 0.36 & MG/L & & 0.25 & 0.25 & & \\
\hline $2 / 8 / 2005$ & EM00008643 & 1798 & GRAB & REG & EPA900.0 & GROSS ALPHA & 2.45 & $\mathrm{PCI} / \mathrm{L}$ & 1.12 & 0 & 1.37 & & \\
\hline $2 / 8 / 2005$ & EM00008643 & 1798 & GRAB & REG & EPA900.0 & GROSS BETA & 5.22 & $\mathrm{PCI} / \mathrm{L}$ & 0.868 & 0 & 1.09 & & \\
\hline 2/8/2005 & EM00008643 & 1798 & GRAB & REG & EPA901.1 & LEAD-212 & 5.93 & $\mathrm{PCI} / \mathrm{L}$ & 6.93 & 0 & 12.4 & $U$ & $\mathrm{U}$ \\
\hline $2 / 8 / 2005$ & EM00008643 & 1798 & GRAB & REG & EPA200.7 & MAGNESIUM & 5990 & UG/L & & 34.2 & 5.7 & & \\
\hline $2 / 8 / 2005$ & EM00008643 & 1798 & GRAB & REG & EPA200.7 & POTASSIUM & 7860 & UG/L & & 50.4 & 8.4 & & \\
\hline $2 / 8 / 2005$ & EM00008643 & 1798 & GRAB & REG & EPA901.1 & POTASSIUM-40 & 43.2 & $\mathrm{PCl} / \mathrm{L}$ & 50.3 & 0 & 68.3 & $U$ & $U$ \\
\hline $2 / 8 / 2005$ & EM00008643 & 1798 & GRAB & REG & EPA901.1 & PROMETHIUM-144 & 0.247 & $\mathrm{PCI} / \mathrm{L}$ & 3.96 & 0 & 7.07 & $U$ & $\mathrm{U}$ \\
\hline $2 / 8 / 2005$ & EM00008643 & 1798 & GRAB & REG & EPA901.1 & PROMETHIUM-146 & -0.4 & $\mathrm{PCI} / \mathrm{L}$ & 4.64 & 0 & 8.37 & $\mathrm{U}$ & $\mathrm{U}$ \\
\hline $2 / 8 / 2005$ & EM00008643 & 1798 & GRAB & REG & EPA901.1 & RUTHENIUM-106 & -11.4 & $\mathrm{PCI} / \mathrm{L}$ & 38.9 & 0 & 58.8 & $U$ & $\mathrm{U}$ \\
\hline $2 / 8 / 2005$ & EM00008643 & 1798 & GRAB & REG & EPA200.7 & SILICON & 9510 & UG/L & & 34.8 & 5.8 & $\mathrm{~N}$ & \\
\hline $2 / 8 / 2005$ & EM00008643 & 1798 & GRAB & REG & EPA200.7 & SODIUM & 52300 & UG/L & & 9 & 1.5 & & \\
\hline $2 / 8 / 2005$ & EM00008643 & 1798 & GRAB & REG & EPA905.0 & STRONTIUM-90 & 0.539 & $\mathrm{PCI} / \mathrm{L}$ & 0.481 & 0 & 1.01 & $\mathrm{U}$ & $\mathrm{U}$ \\
\hline $2 / 8 / 2005$ & EM00008643 & 1798 & GRAB & REG & EPA300.0 & SULFATE (AS SO4) & 3.2 & MG/L & & 0.25 & 0.25 & & \\
\hline $2 / 8 / 2005$ & EM00008643 & 1798 & GRAB & REG & HASL300 & TECHNETIUM-99 & 4.32 & $\mathrm{PCI} / \mathrm{L}$ & 6.74 & 0 & 11.4 & $U$ & $\mathrm{U}$ \\
\hline $2 / 8 / 2005$ & EM00008643 & 1798 & GRAB & REG & EPA901.1 & THORIUM-234 & 141 & $\mathrm{PCI} / \mathrm{L}$ & 228 & 0 & 363 & $U$ & $U$ \\
\hline $2 / 8 / 2005$ & EM00008643 & 1798 & GRAB & REG & EPA160.1 & TOTAL DISSOLVED SOLIDS & 222 & MG/L & & 5 & 5 & & \\
\hline
\end{tabular}


Table B-1. STATION ID: USGS WATER WELL A (continued)

\begin{tabular}{|c|c|c|c|c|c|c|c|c|c|c|c|c|c|c|}
\hline $2 / 8 / 2005$ & EM00008641 & & EB & REG & EPA906.0 & TRITIUM & -26.5 & $\mathrm{PCI} / \mathrm{L}$ & 156 & 0 & 271 & $\mathrm{U}$ & $\mathrm{U}$ & \\
\hline $2 / 8 / 2005$ & EM00008642 & 1798 & FD & REG & EPA906.0 & TRITIUM & 4990 & $\mathrm{PCl} / \mathrm{L}$ & 316 & 0 & 301 & & & \\
\hline $2 / 8 / 2005$ & EM00008643 & 1798 & GRAB & REG & EPA906.0 & TRITIUM & 5240 & $\mathrm{PCI} / \mathrm{L}$ & 319 & 0 & 296 & & & \\
\hline 2/8/2005 & EM00008643 & 1798 & GRAB & REG & EPA901.1 & URANIUM-235 & 13.3 & $\mathrm{PCl} / \mathrm{L}$ & 24.3 & 0 & 43.7 & $u$ & U & \\
\hline $2 / 8 / 2005$ & EM00008643 & 1798 & GRAB & REG & EPA901.1 & URANIUM-238 & 141 & $\mathrm{PCI} / \mathrm{L}$ & 228 & 0 & 363 & $U$ & $\mathrm{U}$ & \\
\hline 2/8/2005 & EM00008643 & 1798 & GRAB & REG & EPA901.1 & YTTRIUM-88 & 7.52 & PCI/L & 7.04 & 0 & 6.26 & $x$ & $\mathrm{R}$ & NVP \\
\hline
\end{tabular}


This Page Intentionally Left Blank 
Table B-2. STATION ID: UE-1Q

\begin{tabular}{|c|c|c|c|c|c|c|c|c|c|c|c|c|c|c|}
\hline \multirow[b]{2}{*}{$\begin{array}{l}\text { SAMPLE } \\
\text { DATE }\end{array}$} & \multirow[b]{2}{*}{ SAMPLE ID } & \multirow[b]{2}{*}{$\begin{array}{l}\text { TOP } \\
\text { DEPTH }\end{array}$} & \multirow[b]{2}{*}{$\begin{array}{l}\text { SAMPLE } \\
\text { TYPE }\end{array}$} & \multirow[b]{2}{*}{$\begin{array}{l}\text { ANALYSIS } \\
\text { CODE }\end{array}$} & \multirow[b]{2}{*}{ METHOD } & \multirow[b]{2}{*}{ ANALYTE NAME } & \multirow[b]{2}{*}{ RESULT } & \multirow[b]{2}{*}{ UNITS } & \multirow[b]{2}{*}{ ERROR } & \multirow{2}{*}{$\begin{array}{l}\text { SAMPLE } \\
\text { QUANTITATION } \\
\text { LIMIT }\end{array}$} & \multirow[b]{2}{*}{$\begin{array}{l}\text { DETECTION } \\
\text { LIMIT }\end{array}$} & \multicolumn{3}{|c|}{ QUALIFIER CODES } \\
\hline & & & & & & & & & & & & LAB & REVIEW & CODE 1 \\
\hline $2 / 17 / 2000$ & EM00001729 & & $\mathrm{N}$ & & L-E10615PL & TRITIUM & -1.34 & $\mathrm{pCi} / \mathrm{L}$ & 6.12 & & 10.2 & $U$ & & \\
\hline $1 / 31 / 2001$ & EM00003349 & 2475 & GRAB & REG & EPA901.1 & ACTINIUM-228 & 10.6 & $\mathrm{PCI} / \mathrm{L}$ & 9.88 & 0 & 19.8 & $U$ & $U$ & \\
\hline $1 / 31 / 2001$ & EM00003349 & 2475 & GRAB & LR1 & EPA901.1 & ACTINIUM-228 & 14.2 & $\mathrm{PCI} / \mathrm{L}$ & 12.1 & 0 & 21.8 & $\mathrm{U}$ & & \\
\hline $1 / 31 / 2001$ & EM00003349 & 2475 & GRAB & LR1 & SM2320B & $\begin{array}{l}\text { ALKALINITY, BICARBONATE } \\
\text { (AS CACO3) }\end{array}$ & 190 & MG/L & & 5 & 1 & & QCD & \\
\hline $1 / 31 / 2001$ & EM00003349 & 2475 & GRAB & REG & SM2320B & $\begin{array}{l}\text { ALKALINITY, BICARBONATE } \\
\text { (AS CACO3) }\end{array}$ & 190 & MG/L & & 5 & 1 & & QCD & \\
\hline $1 / 31 / 2001$ & EM00003349 & 2475 & GRAB & LR1 & SM2320B & $\begin{array}{l}\text { ALKALINITY, CARBOINATE } \\
\text { (AS CACO3) }\end{array}$ & 0 & MG/L & & 5 & & U & QCD & \\
\hline $1 / 31 / 2001$ & EM00003349 & 2475 & GRAB & REG & SM2320B & $\begin{array}{l}\text { ALKALINITY, CARBONATE } \\
\text { (AS CACO3) }\end{array}$ & 0 & MG/L & & 5 & & u & QCD & \\
\hline $1 / 31 / 2001$ & EM00003349 & 2475 & GRAB & REG & EPA901.1 & AMERICIUM-241 & 5.71 & $\mathrm{PCI} / \mathrm{L}$ & 12.1 & 0 & 22.1 & $U$ & $U$ & \\
\hline $1 / 31 / 2001$ & EM00003349 & 2475 & GRAB & LR1 & EPA901.1 & AMERICIUM-241 & -0.915 & $\mathrm{PCI} / \mathrm{L}$ & 20.8 & 0 & 35.5 & $\mathrm{U}$ & & \\
\hline $1 / 31 / 2001$ & EM00003349 & 2475 & GRAB & REG & EPA901.1 & ANTIMONY-125 & -0.315 & $\mathrm{PCI} / \mathrm{L}$ & 6.99 & 0 & 12.4 & $\mathrm{U}$ & $U$ & \\
\hline $1 / 31 / 2001$ & EM00003349 & 2475 & GRAB & LR1 & EPA901.1 & ANTIMONY-125 & -3.26 & $\mathrm{PCI} / \mathrm{L}$ & 7.93 & 0 & 13.5 & $\mathrm{U}$ & & \\
\hline $1 / 31 / 2001$ & EM00003349 & 2475 & GRAB & LR1 & EPA200.7 & CALCIUM & 20 & MG/L & & 0.2 & 0.03 & & QCD & \\
\hline $1 / 31 / 2001$ & EM00003349 & 2475 & GRAB & REG & EPA200.7 & CALCIUM & 20 & MG/L & & 0.2 & 0.03 & & QCD & \\
\hline $1 / 31 / 2001$ & EM00003349 & 2475 & GRAB & REG & EPA901.1 & CERIUM-144 & -6.31 & $\mathrm{PCI} / \mathrm{L}$ & 17.4 & 0 & 29.5 & $U$ & $U$ & \\
\hline $1 / 31 / 2001$ & EM00003349 & 2475 & GRAB & LR1 & EPA901.1 & CERIUM-144 & 15.6 & $\mathrm{PCI} / \mathrm{L}$ & 19.7 & 0 & 31.1 & $\mathrm{U}$ & & \\
\hline $1 / 31 / 2001$ & EM00003349 & 2475 & GRAB & REG & EPA901.1 & CESIUM-134 & -1.54 & $\mathrm{PCI} / \mathrm{L}$ & 2.81 & 0 & 4.7 & $\mathrm{U}$ & $\mathrm{U}$ & \\
\hline $1 / 31 / 2001$ & EM00003349 & 2475 & GRAB & LR1 & EPA901.1 & CESIUM-134 & -1.98 & $\mathrm{PCI} / \mathrm{L}$ & 3.28 & 0 & 4.61 & $\mathrm{U}$ & & \\
\hline $1 / 31 / 2001$ & EM00003349 & 2475 & GRAB & REG & EPA901.1 & CESIUM-137 & 3.82 & $\mathrm{PCI} / \mathrm{L}$ & 4.18 & 0 & 4.75 & $\mathrm{U}$ & $\mathrm{U}$ & \\
\hline $1 / 31 / 2001$ & EM00003349 & 2475 & GRAB & LR1 & EPA901.1 & CESIUM-137 & 4.77 & $\mathrm{PCI} / \mathrm{L}$ & 4.86 & 0 & 5.06 & $U$ & & \\
\hline $1 / 31 / 2001$ & EM00003349 & 2475 & GRAB & LR1 & EPA300.0 & CHLORIDE & 17 & MG/L & & 1 & 0.1 & & QCD & \\
\hline $1 / 31 / 2001$ & EM00003349 & 2475 & GRAB & REG & EPA300.0 & CHLORIDE & 17 & MG/L & & 1 & 0.1 & & QCD & \\
\hline $1 / 31 / 2001$ & EM00003349 & 2475 & GRAB & REG & EPA901.1 & COBALT-60 & -0.0112 & $\mathrm{PCI} / \mathrm{L}$ & 2.95 & 0 & 4.75 & $\mathrm{U}$ & $\mathrm{U}$ & \\
\hline $1 / 31 / 2001$ & EM00003349 & 2475 & GRAB & LR1 & EPA901.1 & COBALT-60 & -1.98 & $\mathrm{PCI} / \mathrm{L}$ & 2.95 & 0 & 4.9 & $\mathrm{U}$ & & \\
\hline $1 / 31 / 2001$ & EM00003349 & 2475 & GRAB & REG & EPA901.1 & EUROPIUM-152 & 2.23 & $\mathrm{PCI} / \mathrm{L}$ & 7.7 & 0 & 12.2 & $\mathrm{U}$ & $\mathrm{U}$ & \\
\hline $1 / 31 / 2001$ & EM00003349 & 2475 & GRAB & LR1 & EPA901.1 & EUROPIUM-152 & -1.82 & $\mathrm{PCI} / \mathrm{L}$ & 8.18 & 0 & 14.2 & $\mathrm{U}$ & & \\
\hline $1 / 31 / 2001$ & EM00003349 & 2475 & GRAB & REG & EPA901.1 & EUROPIUM-154 & 1.96 & $\mathrm{PCI} / \mathrm{L}$ & 8.43 & 0 & 15.9 & $\mathrm{U}$ & $U$ & \\
\hline $1 / 31 / 2001$ & EM00003349 & 2475 & GRAB & LR1 & EPA901.1 & EUROPIUM-154 & -0.948 & $\mathrm{PCI} / \mathrm{L}$ & 7.77 & 0 & 14.2 & $\mathrm{U}$ & & \\
\hline
\end{tabular}


Table B-2. STATION ID: UE-1Q (continued)

\begin{tabular}{|c|c|c|c|c|c|c|c|c|c|c|c|c|c|c|}
\hline $1 / 31 / 2001$ & EM00003349 & 2475 & GRAB & REG & EPA901.1 & EUROPIUM-155 & 3.33 & $\mathrm{PCI} / \mathrm{L}$ & 12.4 & 0 & 15.2 & $\mathrm{U}$ & $\mathrm{U}$ & \\
\hline $1 / 31 / 2001$ & EM00003349 & 2475 & GRAB & LR1 & EPA901.1 & EUROPIUM-155 & -7.38 & $\mathrm{PCI} / \mathrm{L}$ & 11.3 & 0 & 16.2 & $\mathrm{U}$ & & \\
\hline $1 / 31 / 2001$ & EM00003349 & 2475 & GRAB & LR1 & EPA300.0 & FLUORIDE & 0.5 & MG/L & & 0.1 & 0.04 & & QCD & \\
\hline $1 / 31 / 2001$ & EM00003349 & 2475 & GRAB & REG & EPA300.0 & FLUORIDE & 0.51 & MG/L & & 0.1 & 0.04 & & QCD & \\
\hline $1 / 31 / 2001$ & EM00003349 & 2475 & GRAB & LR1 & EPA900.0 & GROSS ALPHA & 6.13 & PCI/L & 3.03 & 0 & 1.13 & & & \\
\hline $1 / 31 / 2001$ & EM00003349 & 2475 & GRAB & REG & EPA900.0 & GROSS ALPHA & 6.77 & $\mathrm{PCI} / \mathrm{L}$ & 4.58 & 0 & 1.52 & & & \\
\hline $1 / 31 / 2001$ & EM00003349 & 2475 & GRAB & REG & EPA900.0 & GROSS ALPHA & 6.77 & $\mathrm{PCI} / \mathrm{L}$ & 4.58 & 0 & 1.52 & & & \\
\hline $1 / 31 / 2001$ & EM00003349 & 2475 & GRAB & LR1 & EPA900.0 & GROSS ALPHA & 6.13 & $\mathrm{PCI} / \mathrm{L}$ & 3.03 & 0 & 1.13 & & & \\
\hline $1 / 31 / 2001$ & EM00003349 & 2475 & GRAB & LR1 & EPA900.0 & GROSS BETA & 14.5 & $\mathrm{PCI} / \mathrm{L}$ & 2.26 & 0 & 1.82 & & & \\
\hline $1 / 31 / 2001$ & EM00003349 & 2475 & GRAB & REG & EPA900.0 & GROSS BETA & 12.5 & $\mathrm{PCI} / \mathrm{L}$ & 2.2 & 0 & 2.11 & & & \\
\hline $1 / 31 / 2001$ & EM00003349 & 2475 & GRAB & REG & EPA900.0 & GROSS BETA & 12.5 & $\mathrm{PCI} / \mathrm{L}$ & 2.2 & 0 & 2.11 & & & \\
\hline $1 / 31 / 2001$ & EM00003349 & 2475 & GRAB & LR1 & EPA900.0 & GROSS BETA & 14.5 & $\mathrm{PCI} / \mathrm{L}$ & 2.26 & 0 & 1.82 & & & \\
\hline $1 / 31 / 2001$ & EM00003349 & 2475 & GRAB & REG & EPA901.1 & LEAD-212 & 4.3 & $\mathrm{PCI} / \mathrm{L}$ & 10.5 & 0 & 7.93 & $U$ & $\mathrm{U}$ & \\
\hline $1 / 31 / 2001$ & EM00003349 & 2475 & GRAB & LR1 & EPA901.1 & LEAD-212 & 5.25 & $\mathrm{PCI} / \mathrm{L}$ & 9.3 & 0 & 8.85 & $\mathrm{U}$ & & \\
\hline $1 / 31 / 2001$ & EM00003349 & 2475 & GRAB & LR1 & EPA200.7 & MAGNESIUM & 14 & MG/L & & 0.1 & 0.02 & & QCD & \\
\hline $1 / 31 / 2001$ & EM00003349 & 2475 & GRAB & REG & EPA200.7 & MAGNESIUM & 14 & $M G / L$ & & 0.1 & 0.02 & & QCD & \\
\hline $1 / 31 / 2001$ & EM00003349 & 2475 & GRAB & REG & HASL300 & PLUTONIUM-238 & 0.0126 & $\mathrm{PCI} / \mathrm{L}$ & 0.0247 & 0 & 0.0482 & $U$ & $\mathrm{U}$ & \\
\hline $1 / 31 / 2001$ & EM00003349 & 2475 & GRAB & REG & HASL300 & PLUTONIUM-239/240 & 0 & $\mathrm{PCI} / \mathrm{L}$ & 0.0175 & 0 & 0.0482 & U & U & \\
\hline $1 / 31 / 2001$ & EM00003349 & 2475 & GRAB & LR1 & EPA200.7 & POTASSIUM & 15 & $M G / L$ & & 5 & 0.4 & & QCD & \\
\hline $1 / 31 / 2001$ & EM00003349 & 2475 & GRAB & REG & EPA200.7 & POTASSIUM & 16 & MG/L & & 5 & 0.4 & & QCD & \\
\hline $1 / 31 / 2001$ & EM00003349 & 2475 & GRAB & REG & EPA901.1 & POTASSIUM-40 & 44.6 & $\mathrm{PCI} / \mathrm{L}$ & 52.8 & 0 & 53.3 & U & $\mathrm{U}$ & \\
\hline $1 / 31 / 2001$ & EM00003349 & 2475 & GRAB & LR1 & EPA901.1 & POTASSIUM-40 & 8.75 & $\mathrm{PCI} / \mathrm{L}$ & 62.9 & 0 & 47.6 & U & & \\
\hline $1 / 31 / 2001$ & EM00003349 & 2475 & GRAB & REG & EPA901.1 & PROMETHIUM-144 & 0.348 & PCI/L & 3.02 & 0 & 5.3 & U & $\mathrm{U}$ & \\
\hline $1 / 31 / 2001$ & EM00003349 & 2475 & GRAB & LR1 & EPA901.1 & PROMETHIUM-144 & 0.609 & $\mathrm{PCI} / \mathrm{L}$ & 2.98 & 0 & 5.23 & U & & \\
\hline $1 / 31 / 2001$ & EM00003349 & 2475 & GRAB & REG & EPA901.1 & PROMETHIUM-146 & -0.577 & $\mathrm{PCI} / \mathrm{L}$ & 4.06 & 0 & 6.25 & U & $\mathrm{U}$ & \\
\hline $1 / 31 / 2001$ & EM00003349 & 2475 & GRAB & LR1 & EPA901.1 & PROMETHIUM-146 & -1.62 & $\mathrm{PCI} / \mathrm{L}$ & 3.88 & 0 & 6.56 & $U$ & & \\
\hline $1 / 31 / 2001$ & EM00003349 & 2475 & GRAB & REG & EPA901.1 & RUTHENIUM-106 & 4.48 & $\mathrm{PCI} / \mathrm{L}$ & 27.5 & 0 & 48.8 & U & $\mathrm{U}$ & \\
\hline $1 / 31 / 2001$ & EM00003349 & 2475 & GRAB & LR1 & EPA901.1 & RUTHENIUM-106 & 5.11 & $\mathrm{PCI} / \mathrm{L}$ & 44.2 & 0 & 45.2 & U & & \\
\hline $1 / 31 / 2001$ & EM00003349 & 2475 & GRAB & LR1 & EPA200.7 & SODIUM & 65 & $M G / L$ & & 1 & 0.1 & & QCD & \\
\hline $1 / 31 / 2001$ & EM00003349 & 2475 & GRAB & REG & EPA200.7 & SODIUM & 67 & MG/L & & 1 & 0.1 & & QCD & \\
\hline $1 / 31 / 2001$ & EM00003349 & 2475 & GRAB & LR1 & EPA300.0 & SULFATE & 27 & $M G / L$ & & 1 & 0.6 & & QCD & \\
\hline $1 / 31 / 2001$ & EM00003349 & 2475 & GRAB & REG & EPA300.0 & SULFATE & 27 & $M G / L$ & & 1 & 0.6 & & QCD & \\
\hline $1 / 31 / 2001$ & EM00003349 & 2475 & GRAB & REG & EPA901.1 & THORIUM-234 & 133 & $\mathrm{PCI} / \mathrm{L}$ & 105 & 0 & 195 & $\mathrm{U}$ & $\mathrm{U}$ & \\
\hline $1 / 31 / 2001$ & EM00003349 & 2475 & GRAB & LR1 & EPA901.1 & THORIUM-234 & 192 & $\mathrm{PCI} / \mathrm{L}$ & 252 & 0 & 313 & U & & \\
\hline
\end{tabular}

B-12 
Table B-2. STATION ID: UE-1Q (continued)

\begin{tabular}{|c|c|c|c|c|c|c|c|c|c|c|c|c|c|c|}
\hline $1 / 31 / 2001$ & EM00003349 & 2475 & GRAB & LR1 & EPA160.1 & TOTAL DISSOLVED SOLIDS & 270 & MG/L & & 20 & 10 & & QCD & \\
\hline $1 / 31 / 2001$ & EM00003349 & 2475 & GRAB & REG & EPA160.1 & TOTAL DISSOLVED SOLIDS & 270 & MG/L & & 20 & 10 & & QCD & \\
\hline $1 / 31 / 2001$ & EM00003348 & & EB & REG & EPA906.0 & TRITIUM & 518 & $\mathrm{PCI} / \mathrm{L}$ & 151 & 0 & 226 & & & \\
\hline $1 / 31 / 2001$ & EM00003349 & 2475 & GRAB & REG & EPA906.0 & TRITIUM & -127 & $\mathrm{PCI} / \mathrm{L}$ & 142 & 0 & 258 & $U$ & $u$ & \\
\hline $1 / 31 / 2001$ & EM00003349 & 2475 & GRAB & REG & EPA901.1 & URANIUM-235 & 5.51 & $\mathrm{PCI} / \mathrm{L}$ & 25.8 & 0 & 27.6 & U & U & \\
\hline $1 / 31 / 2001$ & EM00003349 & 2475 & GRAB & LR1 & EPA901.1 & URANIUM-235 & -4.93 & $\mathrm{PCI} / \mathrm{L}$ & 19.5 & 0 & 32 & $U$ & & \\
\hline $1 / 31 / 2001$ & EM00003349 & 2475 & GRAB & REG & EPA901.1 & URANIUM-238 & 133 & $\mathrm{PCI} / \mathrm{L}$ & 105 & 0 & 195 & $u$ & $u$ & \\
\hline $1 / 31 / 2001$ & EM00003349 & 2475 & GRAB & LR1 & EPA901.1 & URANIUM-238 & 192 & $\mathrm{PCI} / \mathrm{L}$ & 252 & 0 & 273 & $u$ & & \\
\hline $1 / 31 / 2001$ & EM00003349 & 2475 & GRAB & REG & EPA901.1 & YTTRIUM-88 & -0.177 & $\mathrm{PCI} / \mathrm{L}$ & 3.95 & 0 & 7.45 & $U$ & $u$ & \\
\hline $1 / 31 / 2001$ & EM00003349 & 2475 & GRAB & LR1 & EPA901.1 & YTTRIUM-88 & -0.592 & $\mathrm{PCI} / \mathrm{L}$ & 4.74 & 0 & 7.59 & $U$ & & \\
\hline $1 / 15 / 2002$ & EM00004611 & 2475 & GRAB & REG & EPA906.0 & CARBON-14 & -231 & $\mathrm{pCi} / \mathrm{L}$ & 116 & & 187 & $U$ & U & \\
\hline $1 / 15 / 2002$ & EM00004610 & 2475 & $F D$ & REG & DOE RP550 & TECHNETIUM-99 & -1.11 & $\mathrm{pCi} / \mathrm{L}$ & 1.76 & & 6.01 & $U$ & $U$ & \\
\hline $1 / 15 / 2002$ & EM00004611 & 2475 & GRAB & REG & DOE RP550 & TECHNETIUM-99 & -1.04 & $\mathrm{pCi} / \mathrm{L}$ & 1.65 & & 5.63 & $U$ & $u$ & \\
\hline $1 / 15 / 2002$ & EM00004609 & & EB & REG & EPA906.0 & TRITIUM & 4.36 & $\mathrm{PCI} / \mathrm{L}$ & 131 & & 225 & $U$ & $U$ & \\
\hline $1 / 15 / 2002$ & EM00004609 & & EB & LR1 & EPA906.0 & TRITIUM & 6.55 & $\mathrm{PCI} / \mathrm{L}$ & 131 & & 225 & $U$ & & \\
\hline $1 / 15 / 2002$ & EM00004611 & 2475 & GRAB & REG & EPA906.0 & TRITIUM & -24 & $\mathrm{PCI} / \mathrm{L}$ & 130 & & 225 & $U$ & $\mathrm{U}$ & \\
\hline 10/16/2002 & EM00005396 & & GRAB & REG & EPA901.1 & ACTINIUM-228 & 5.06 & $\mathrm{pCi} / \mathrm{L}$ & 11.2 & & 18.5 & $U$ & $U$ & \\
\hline 10/16/2002 & EM00005396 & & GRAB & DUP & EPA901.1 & ACTINIUM-228 & 0.0291 & $\mathrm{pCi} / \mathrm{L}$ & 24 & & 41.5 & $U$ & & \\
\hline 10/16/2002 & EM00005396 & & GRAB & REG & EPA310.1 & $\begin{array}{l}\text { ALKALINITY, BICARBONATE } \\
\text { (AS CACO3) }\end{array}$ & 169 & MG/L & & 2 & 0.5 & & & \\
\hline $10 / 16 / 2002$ & EM00005396 & & GRAB & REG & EPA310.1 & $\begin{array}{l}\text { ALKALIINITY, CARBOINATE } \\
\text { (AS CACO3) }\end{array}$ & 1 & MG/L & & 1 & 0.5 & $u$ & $\mathrm{U}$ & \\
\hline 10/16/2002 & EM00005396 & & GRAB & REG & EPA901.1 & AMERICIUM-241 & 8.69 & $\mathrm{pCi} / \mathrm{L}$ & 12 & & 19.6 & $U$ & $U$ & \\
\hline 10/16/2002 & EM00005396 & & GRAB & DUP & EPA901.1 & AMERICIUM-241 & -16.1 & $\mathrm{pCi} / \mathrm{L}$ & 26 & & 45.9 & $\mathrm{u}$ & & \\
\hline 10/16/2002 & EM000005396 & & GRAB & REG & EPA901.1 & ANTIMONY-125 & 1.56 & $\mathrm{pCi} / \mathrm{L}$ & 4.63 & & 8.44 & $U$ & $\mathrm{U}$ & \\
\hline $10 / 16 / 2002$ & EM00005396 & & GRAB & DUP & EPA901.1 & ANTIMONY-125 & -1.5 & $\mathrm{pCi} / \mathrm{L}$ & 10.4 & & 18.3 & $U$ & & \\
\hline $10 / 16 / 2002$ & EM00005396 & & GRAB & REG & EPA200.7 & CALCIUM & 20700 & UG/L & & 11.7 & 11.7 & & & \\
\hline 10/16/2002 & EM00005396 & & GRAB & LR1 & EPA200.7 & CALCIUM & 20686 & UG/L & & 11.7 & 11.7 & & & \\
\hline 10/16/2002 & EM00005396 & & GRAB & REG & EERF C01 & CARBON-14 & 56.5 & $\mathrm{pCi} / \mathrm{L}$ & 103 & & 170 & $U$ & $\mathrm{~J}$ & 8 \\
\hline 10/16/2002 & EM00005396 & & GRAB & DUP & EERF C01 & CARBON-14 & 133 & $\mathrm{pCi} / \mathrm{L}$ & 106 & & 170 & $U$ & $\mathrm{~J}$ & 8 \\
\hline 10/16/2002 & EM00005396 & & GRAB & REG & EPA901.1 & CERIUM-144 & 2.39 & $\mathrm{pCi} / \mathrm{L}$ & 11.9 & & 19.8 & $U$ & $\mathrm{U}$ & \\
\hline 10/16/2002 & EM00005396 & & GRAB & DUP & EPA901.1 & CERIUM-144 & 8.49 & $\mathrm{pCi} / \mathrm{L}$ & 20 & & 33.6 & $U$ & & \\
\hline $10 / 16 / 2002$ & EM00005396 & & GRAB & REG & EPA901.1 & CESIUM-134 & 0.622 & $\mathrm{pCi} / \mathrm{L}$ & 3.2 & & 5.3 & $U$ & $\mathrm{U}$ & \\
\hline $10 / 16 / 2002$ & EM00005396 & & GRAB & DUP & EPA901.1 & CESIUM-134 & -1.17 & $\mathrm{pCi} / \mathrm{L}$ & 4.52 & & 7.95 & $U$ & & \\
\hline $10 / 16 / 2002$ & EM00005396 & & GRAB & REG & EPA901.1 & CESIUM-137 & -0.0662 & $\mathrm{pCi} / \mathrm{L}$ & 2.03 & & 3.42 & $U$ & $U$ & \\
\hline 10/16/2002 & EM00005396 & & GRAB & DUP & EPA901.1 & CESIUM-137 & 1.91 & $\mathrm{pCi} / \mathrm{L}$ & 4.26 & & 7.2 & $u$ & & \\
\hline
\end{tabular}

B-13 
Table B-2. STATION ID: UE-1Q (continued)

\begin{tabular}{|c|c|c|c|c|c|c|c|c|c|c|c|c|c|}
\hline 10/16/2002 & EM00005396 & GRAB & REG & EPA300.0 & CHLORIDE & 19 & MG/L & & 1.2 & 0.25 & & & \\
\hline 10/16/2002 & EM00005396 & GRAB & LR1 & EPA300.0 & CHLORIDE & 18.1 & MG/L & & 1.2 & 0.25 & & & \\
\hline $10 / 16 / 2002$ & EM00005396 & GRAB & REG & EPA901.1 & COBALT-60 & -0.794 & $\mathrm{pCi} / \mathrm{L}$ & 2.13 & & 3.67 & U & U & \\
\hline $10 / 16 / 2002$ & EM00005396 & GRAB & DUP & EPA901.1 & COBALT-60 & 3.36 & $\mathrm{pCi} / \mathrm{L}$ & 4.12 & & 6.68 & U & & \\
\hline 10/16/2002 & EM00005396 & GRAB & REG & EPA901.1 & EUROPIUM-152 & 5.44 & $\mathrm{pCi} / \mathrm{L}$ & 10.5 & & 17.4 & U & $\mathrm{U}$ & \\
\hline 10/16/2002 & EM00005396 & GRAB & DUP & EPA901.1 & EUROPIUM-152 & -4.11 & $\mathrm{pCi} / \mathrm{L}$ & 21.6 & & 39.8 & u & & \\
\hline $10 / 16 / 2002$ & EM00005396 & GRAB & REG & EPA901.1 & EUROPIUM-154 & 3.1 & $\mathrm{pCi} / \mathrm{L}$ & 11.3 & & 18.9 & U & $\mathrm{U}$ & \\
\hline 10/16/2002 & EM00005396 & GRAB & DUP & EPA901.1 & EUROPIUM-154 & -8.87 & $\mathrm{pCi} / \mathrm{L}$ & 18.7 & & 35.6 & $U$ & & \\
\hline 10/16/2002 & EM00005396 & GRAB & REG & EPA901.1 & EUROPIUM-155 & -0.0287 & $\mathrm{pCi} / \mathrm{L}$ & 7.11 & & 11.9 & $U$ & $\mathrm{U}$ & \\
\hline 10/16/2002 & EM00005396 & GRAB & DUP & EPA901.1 & EUROPIUM-155 & -2.09 & $\mathrm{pCi} / \mathrm{L}$ & 10.9 & & 18.9 & $U$ & & \\
\hline 10/16/2002 & EM00005396 & GRAB & REG & EPA300.0 & FLUORIDE & 0.46 & $\mathrm{MG} / \mathrm{L}$ & & 0.25 & 0.25 & & & \\
\hline 10/16/2002 & EM00005396 & GRAB & LR1 & EPA300.0 & FLUORIDE & 0.45 & MG/L & & 0.25 & 0.25 & & & \\
\hline 10/16/2002 & EM00005396 & GRAB & REG & EPA900.0 & GROSS ALPHA & 4.02 & $\mathrm{pCi} / \mathrm{L}$ & 1.77 & & 2.39 & & & \\
\hline 10/16/2002 & EM00005396 & GRAB & DUP & EPA900.0 & GROSS ALPHA & 4.7 & $\mathrm{pCi} / \mathrm{L}$ & 1.63 & & 1.88 & & & \\
\hline 10/16/2002 & EM00005396 & GRAB & REG & EPA900.0 & GROSS BETA & 9.31 & $\mathrm{pCi} / \mathrm{L}$ & 1.97 & & 2.09 & & & \\
\hline 10/16/2002 & EM00005396 & GRAB & DUP & EPA900.0 & GROSS BETA & 9.48 & $\mathrm{pCi} / \mathrm{L}$ & 1.99 & & 2.09 & & & \\
\hline 10/16/2002 & EM00005396 & GRAB & REG & EPA901.1 & LEAD-212 & -2.73 & $\mathrm{pCi} / \mathrm{L}$ & 5.41 & & 9.04 & $U$ & $U$ & \\
\hline 10/16/2002 & EM00005396 & GRAB & DUP & EPA901.1 & LEAD-212 & -0.223 & $\mathrm{pCi} / \mathrm{L}$ & 8.71 & & 15 & U & & \\
\hline 10/16/2002 & EM00005396 & GRAB & REG & EPA200.7 & MAGNESIUM & 13400 & UG/L & & 7.7 & 7.7 & & & \\
\hline 10/16/2002 & EM00005396 & GRAB & LR1 & EPA200.7 & MAGNESIUM & 13353 & UG/L & & 7.7 & 7.7 & & & \\
\hline 10/16/2002 & EM00005396 & GRAB & REG & ASTMD3972-90M & PLUTONIUM-238 & 0.000953 & $\mathrm{pCi} / \mathrm{L}$ & 0.0189 & & 0.044 & $\mathrm{U}$ & $\mathrm{U}$ & \\
\hline 10/16/2002 & EM00005396 & GRAB & REG & ASTMD3972-90M & PLUTONIUM-239/240 & -0.00286 & $\mathrm{pCi} / \mathrm{L}$ & 0.0189 & & 0.0314 & $U$ & $U$ & \\
\hline 10/16/2002 & EM00005396 & GRAB & REG & EPA200.7 & POTASSIUM & 11800 & UG/L & & 28.1 & 28.1 & & & \\
\hline 10/16/2002 & EM00005396 & GRAB & LR1 & EPA200.7 & POTASSIUM & 11813 & UG/L & & 28.1 & 28.1 & & & \\
\hline 10/16/2002 & EM00005396 & GRAB & REG & EPA901.1 & POTASSIUM-40 & -40.3 & $\mathrm{pCi} / \mathrm{L}$ & 45.4 & & 76.2 & $U$ & $\mathrm{U}$ & \\
\hline 10/16/2002 & EM00005396 & GRAB & DUP & EPA901.1 & POTASSIUM-40 & 72.3 & $\mathrm{pCi} / \mathrm{L}$ & 86.7 & & 141 & $\mathrm{U}$ & & \\
\hline 10/16/2002 & EM00005396 & GRAB & REG & EPA901.1 & PROMETHIUM-144 & 2.56 & $\mathrm{pCi} / \mathrm{L}$ & 2.1 & & 3.33 & $U$ & $\mathrm{U}$ & \\
\hline 10/16/2002 & EM00005396 & GRAB & DUP & EPA901.1 & PROMETHIUM-144 & -2.19 & $\mathrm{pCi} / \mathrm{L}$ & 4.54 & & 8.16 & $U$ & & \\
\hline 10/16/2002 & EM00005396 & GRAB & REG & EPA901.1 & PROMETHIUM-146 & 0.699 & $\mathrm{pCi} / \mathrm{L}$ & 2.27 & & 3.8 & $U$ & $U$ & \\
\hline 10/16/2002 & EM00005396 & GRAB & DUP & EPA901.1 & PROMETHIUM-146 & -3.2 & $\mathrm{pCi} / \mathrm{L}$ & 5.1 & & 9.16 & $U$ & & \\
\hline 10/16/2002 & EM00005396 & GRAB & REG & EPA901.1 & RUTHENIUM-106 & -16.1 & $\mathrm{pCi} / \mathrm{L}$ & 20 & & 34.2 & $U$ & $U$ & \\
\hline 10/16/2002 & EM00005396 & GRAB & DUP & EPA901.1 & RUTHENIUM-106 & 4.65 & $\mathrm{pCi} / \mathrm{L}$ & 40.1 & & 69.5 & U & & \\
\hline $10 / 16 / 2002$ & EM00005396 & GRAB & REG & EPA200.7 & SILICON & 19800 & UG/L & & 6.9 & 6.9 & & $\mathrm{~J}$ & 25 \\
\hline
\end{tabular}

B-14 
Table B-2. STATION ID: UE-1Q (continued)

\begin{tabular}{|c|c|c|c|c|c|c|c|c|c|c|c|c|c|c|}
\hline $10 / 16 / 2002$ & EM00005396 & & GRAB & LR1 & EPA200.7 & SILICON & 19930 & UG/L & & 6.9 & 6.9 & & $\mathrm{~J}$ & 25 \\
\hline 10/16/2002 & EM00005396 & & GRAB & REG & EPA200.7 & SODIUM & 50000 & UG/L & & 5.3 & 5.3 & & & \\
\hline 10/16/2002 & EM00005396 & & GRAB & LR1 & EPA200.7 & SODIUM & 50117 & UG/L & & 5.3 & 5.3 & & & \\
\hline 10/16/2002 & EM00005396 & & GRAB & REG & EPA300.0 & SULFATE (AS SO4) & 27.2 & MG/L & & 1.2 & 0.25 & & & \\
\hline 10/16/2002 & EM00005396 & & GRAB & LR1 & EPA300.0 & SULFATE (AS SO4) & 26.6 & MG/L & & 1.2 & 0.25 & & & \\
\hline 10/16/2002 & EM00005396 & & GRAB & REG & DOE RP550 & TECHNETIUM-99 & 7.67 & $\mathrm{pCi} / \mathrm{L}$ & 5.12 & & 8.02 & $2 \mid U$ & U & \\
\hline 10/16/2002 & EM00005396 & & GRAB & DUP & DOE RP550 & TECHNETIUM-99 & 5.77 & $\mathrm{pCi} / \mathrm{L}$ & 5.11 & & 8.19 & 9 & & \\
\hline 10/16/2002 & EM00005396 & & GRAB & REG & EPA901.1 & THORIUM-234 & -6.54 & $\mathrm{pCi} / \mathrm{L}$ & 61.8 & & 103 & \begin{tabular}{l|l}
3 & $U$ \\
\end{tabular} & $U$ & \\
\hline 10/16/2002 & EM00005396 & & GRAB & DUP & EPA901.1 & THORIUM-234 & 36.8 & $\mathrm{pCi} / \mathrm{L}$ & 92.5 & & 162 & 2 U & & \\
\hline $10 / 16 / 2002$ & EM00005396 & & GRAB & REG & EPA160.1 & TOTAL DISSOLVED SOLIDS & 270 & MG/L & & 5 & 5 & 5 & & \\
\hline 10/16/2002 & EM00005396 & & GRAB & LR1 & EPA160.1 & TOTAL DISSOLVED SOLIDS & 272 & MG/L & & 5 & 5 & 5 & & \\
\hline $10 / 16 / 2002$ & EM00005763 & & EB & REG & EPA906.0 & TRITIUM & 134 & $\mathrm{PCI} / \mathrm{L}$ & 149 & & 243 & $\begin{array}{l}3 \\
\end{array}$ & $\mathrm{U}$ & \\
\hline $10 / 16 / 2002$ & EM00005763 & & EB & LR1 & EPA906.0 & TRITIUM & -93.2 & $\mathrm{PCI} / \mathrm{L}$ & 137 & & 243 & 3 & & \\
\hline $10 / 16 / 2002$ & EM00005764 & & FD & REG & EPA906.0 & TRITIUM & -31.8 & $\mathrm{PCI} / \mathrm{L}$ & 140 & & 243 & $\begin{array}{l}3 \\
\end{array}$ & $U$ & \\
\hline 10/16/2002 & EM00005396 & & GRAB & REG & EPA906.0 & TRITIUM & 66.4 & $\mathrm{PCl} / \mathrm{L}$ & 156 & & 260 & $0 \mid u$ & U & \\
\hline $10 / 16 / 2002$ & EM00005396 & & GRAB & LR1 & EPA906.0 & TRITIUM & 274 & $\mathrm{PCI} / \mathrm{L}$ & 165 & & 261 & \begin{tabular}{l|l}
1 & $B$ \\
\end{tabular} & & \\
\hline 10/16/2002 & EM00005396 & & GRAB & REG & EPA906.0 & TRITIUM & 66.4 & $\mathrm{PCI} / \mathrm{L}$ & 156 & & 260 & 0.0 & $U$ & \\
\hline $10 / 16 / 2002$ & EM00005396 & & GRAB & LR1 & EPA906.0 & TRITIUM & 274 & $\mathrm{PCI} / \mathrm{L}$ & 165 & & 261 & \begin{tabular}{l|l}
1 & $B$ \\
\end{tabular} & & \\
\hline $10 / 16 / 2002$ & EM00005396 & & GRAB & REG & EPA901.1 & URANIUM-235 & 14.2 & $\mathrm{pCi} / \mathrm{L}$ & 11 & & 17.5 & 5 & $U$ & \\
\hline 10/16/2002 & EM00005396 & & GRAB & DUP & EPA901.1 & URANIUM-235 & -2.01 & $\mathrm{pCi} / \mathrm{L}$ & 22.6 & & 38.6 & $\begin{array}{l}6 \\
\end{array}$ & & \\
\hline 10/16/2002 & EM00005396 & & GRAB & REG & EPA901.1 & YTTRIUM-88 & 2.1 & $\mathrm{pCi} / \mathrm{L}$ & 2.7 & & 4.41 & 1 U & $U$ & \\
\hline $10 / 16 / 2002$ & EM00005396 & & GRAB & DUP & EPA901.1 & YTTRIUM-88 & -1.13 & $\mathrm{pCi} / \mathrm{L}$ & 10.1 & & 17.4 & 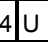 & & \\
\hline $1 / 21 / 2003$ & EM00006029 & 2475 & GRAB & DUP & EPA901.1 & ACTINIUM-228 & -7.83 & $\mathrm{pCi} / \mathrm{L}$ & 26 & & 45.9 & \begin{tabular}{l|l}
9 & $U$ \\
\end{tabular} & $\mathrm{U}$ & \\
\hline $1 / 21 / 2003$ & EM00006029 & 2475 & GRAB & REG & EPA901.1 & ACTINIUM-228 & 13.2 & $\mathrm{pCi} / \mathrm{L}$ & 14.3 & & 23.1 & $1 \mathrm{U}$ & $U$ & \\
\hline $1 / 21 / 2003$ & EM00006029 & 2475 & GRAB & DUP & EPA901.1 & AMERICIUM-241 & 2.02 & $\mathrm{pCi} / \mathrm{L}$ & 5.05 & & 8.48 & 8 & $U$ & \\
\hline $1 / 21 / 2003$ & EM00006029 & 2475 & GRAB & REG & EPA901.1 & AMERICIUM-241 & 1.12 & $\mathrm{pCi} / \mathrm{L}$ & 4.9 & & 8.23 & \begin{tabular}{|l|l}
3 & $U$ \\
\end{tabular} & $U$ & \\
\hline $1 / 21 / 2003$ & EM00006029 & 2475 & GRAB & REG & EPA901.1 & ANTIMONY-125 & -0.219 & $\mathrm{pCi} / \mathrm{L}$ & 6.7 & & 13 & $\begin{array}{l}3 \\
\end{array}$ & $U$ & \\
\hline $1 / 21 / 2003$ & EM00006029 & 2475 & GRAB & DUP & EPA901.1 & ANTIMONY-125 & -6.61 & $\mathrm{pCi} / \mathrm{L}$ & 11.1 & & 19.9 & $\begin{array}{l}9 \\
\end{array}$ & $U$ & \\
\hline $1 / 21 / 2003$ & EM00006029 & 2475 & GRAB & REG & SM2320B & BICARBONATE & 176 & $\mathrm{MG} / \mathrm{L}$ & & 2 & 2 & 2 & $\mathrm{R}$ & 2 \\
\hline $1 / 21 / 2003$ & EM00006029 & 2475 & GRAB & REG & EPA200.7 & CALCIUM & 21100 & UG/L & & 10.2 & 10.2 & & & \\
\hline $1 / 21 / 2003$ & EM00006029 & 2475 & GRAB & REG & EERF C01 & CARBON-14 & 0 & $\mathrm{pCi} / \mathrm{L}$ & 110 & & 183 & \begin{tabular}{l|l}
3 & $U$ \\
\end{tabular} & $U$ & \\
\hline $1 / 21 / 2003$ & EM00006029 & 2475 & GRAB & REG & SM2320B & CARBONATE (AS CO3) & 2 & $M G / L$ & & 2 & & 2 U & $R$ & 2 \\
\hline $1 / 21 / 2003$ & EM00006029 & 2475 & GRAB & DUP & EPA901.1 & CERIUM-144 & 4.26 & $\mathrm{pCi} / \mathrm{L}$ & 16.8 & & 28.4 & $\begin{array}{l}4 \\
\end{array}$ & $U$ & \\
\hline $1 / 21 / 2003$ & EM00006029 & 2475 & GRAB & REG & EPA901.1 & CERIUM-144 & 5.03 & $\mathrm{pCi} / \mathrm{L}$ & 14.5 & & 24.3 & $\begin{array}{l}3 \\
\end{array}$ & U & \\
\hline
\end{tabular}

B-15 
Table B-2. STATION ID: UE-1Q (continued)

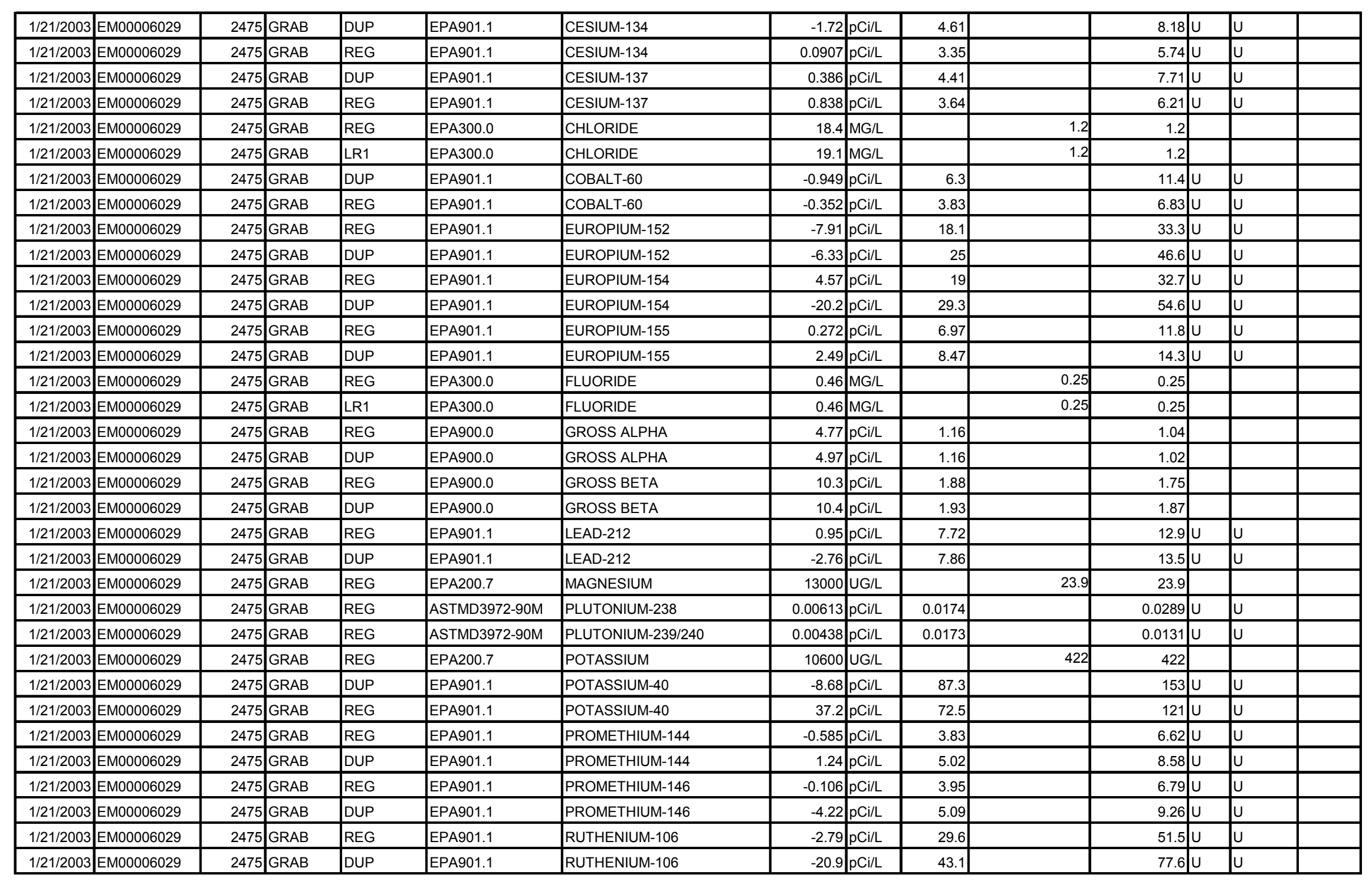

B-16 
Table B-2. STATION ID: UE-1Q (continued)

\begin{tabular}{|c|c|c|c|c|c|c|c|c|c|c|c|c|c|c|}
\hline $1 / 21 / 2003$ & EM00006029 & 2475 & GRAB & REG & EPA200.7 & SILICON & 19900 & UG/L & & 7.3 & 7.3 & & & \\
\hline $1 / 21 / 2003$ & EM00006029 & 2475 & GRAB & REG & EPA200.7 & SODIUM & 53900 & UG/L & & 17.6 & 17.6 & & & \\
\hline $1 / 21 / 2003$ & EM00006029 & 2475 & GRAB & REG & EPA300.0 & SULFATE (AS SO4) & 27.6 & MG/L & & 1.2 & 1.2 & & $R$ & 2 \\
\hline $1 / 21 / 2003$ & EM00006029 & 2475 & GRAB & LR1 & EPA300.0 & SULFATE (AS SO4) & 27.8 & MG/L & & 1.2 & 1.2 & & $R$ & 2 \\
\hline $1 / 21 / 2003$ & EM00006029 & 2475 & GRAB & REG & DOE RP550 & TECHNITIUM-99 & -0.593 & $\mathrm{pCi} / \mathrm{L}$ & 2.13 & & 3.6 & $U$ & $\mathrm{U}$ & \\
\hline $1 / 21 / 2003$ & EM00006029 & 2475 & GRAB & DUP & DOE RP550 & TECHNITIUM-99 & -0.017 & $\mathrm{pCi} / \mathrm{L}$ & 2.24 & & 3.76 & $\mathrm{U}$ & $\mathrm{U}$ & \\
\hline $1 / 21 / 2003$ & EM00006029 & 2475 & GRAB & REG & EPA901.1 & THORIUM-234 & -19.7 & $\mathrm{pCi} / \mathrm{L}$ & 52.1 & & 87.7 & $\mathrm{U}$ & U & \\
\hline $1 / 21 / 2003$ & EM00006029 & 2475 & GRAB & DUP & EPA901.1 & THORIUM-234 & 85.5 & $\mathrm{pCi} / \mathrm{L}$ & 31.1 & & 39 & $\mathrm{JN}$ & & \\
\hline $1 / 21 / 2003$ & EM00006029 & 2475 & GRAB & REG & EPA160.1 & TOTAL DISSOLVED SOLIDS & 281 & MG/L & & 5 & 5 & & $R$ & 2 \\
\hline $1 / 21 / 2003$ & EM00006029 & 2475 & GRAB & LR1 & EPA160.1 & TOTAL DISSOLVED SOLIDS & 276 & MG/L & & 5 & 5 & & $R$ & 2 \\
\hline $1 / 21 / 2003$ & EM00006027 & & EB & REG & EPA906.0 & TRITIUM & -2.29 & $\mathrm{PCI} / \mathrm{L}$ & 158 & & 270 & $\mathrm{U}$ & $\mathrm{U}$ & \\
\hline $1 / 21 / 2003$ & EM00006027 & & EB & LR1 & EPA906.0 & TRITIUM & -126 & $\mathrm{PCI} / \mathrm{L}$ & 152 & & 270 & $U$ & & \\
\hline $1 / 21 / 2003$ & EM00006028 & 2475 & FD & REG & EPA906.0 & TRITIUM & 115 & $\mathrm{PCI} / \mathrm{L}$ & 322 & & 541 & $\mathrm{U}$ & U & \\
\hline $1 / 21 / 2003$ & EM00006029 & 2475 & GRAB & REG & EPA906.0 & TRITIUM & 101 & $\mathrm{PCI} / \mathrm{L}$ & 163 & & 270 & $\mathrm{U}$ & $\mathrm{U}$ & \\
\hline $1 / 21 / 2003$ & EM00006029 & 2475 & GRAB & DUP & EPA901.1 & URANIUM-235 & -1.43 & $\mathrm{pCi} / \mathrm{L}$ & 24 & & 40.8 & $U$ & $\mathrm{U}$ & \\
\hline $1 / 21 / 2003$ & EM00006029 & 2475 & GRAB & REG & EPA901.1 & URANIUM-235 & -6.76 & $\mathrm{pCi} / \mathrm{L}$ & 18.5 & & 31.5 & $U$ & U & \\
\hline $1 / 21 / 2003$ & EM00006029 & 2475 & GRAB & DUP & EPA901.1 & YTTRIUM-88 & 0.886 & $\mathrm{pCi} / \mathrm{L}$ & 4.91 & & 8.59 & $\mathrm{U}$ & $\mathrm{U}$ & \\
\hline $1 / 21 / 2003$ & EM00006029 & 2475 & GRAB & REG & EPA901.1 & YTTRIUM-88 & 2.68 & $\mathrm{pCi} / \mathrm{L}$ & 5.77 & & 9.63 & $U$ & $\mathrm{U}$ & \\
\hline $9 / 3 / 2003$ & EM00006769 & & GRAB & REG & EPA901.1 & ACTINIUM-228 & -5.34 & $\mathrm{pCi} / \mathrm{L}$ & 24.8 & & 43.4 & $U$ & U & \\
\hline 9/3/2003 & EM00006769 & & GRAB & DUP & EPA901.1 & ACTINIUM-228 & 3.65 & $\mathrm{pCi} / \mathrm{L}$ & 25.9 & & 44.3 & $\mathrm{U}$ & U & \\
\hline 9/3/2003 & EM00006769 & & GRAB & REG & SM2320B & $\begin{array}{l}\text { ALKALINITY, BICARBONATE } \\
\text { (AS CACO3) }\end{array}$ & 154 & MG/L & & 2 & 0.5 & & & \\
\hline $9 / 3 / 2003$ & EM00006769 & & GRAB & LR1 & SM2320B & $\begin{array}{l}\text { ALKALINITY, BICARBONATE } \\
\text { (AS CACO3) }\end{array}$ & 155 & MG/L & & 2 & 0.5 & & & \\
\hline $9 / 3 / 2003$ & EM00006769 & & GRAB & REG & SM2320B & $\begin{array}{l}\text { ALKALINITY, CARBONATIE } \\
\text { (AS CACO3) }\end{array}$ & 2 & MG/L & & 2 & 0.5 & U & u & \\
\hline 9/3/2003 & EM00006769 & & GRAB & LR1 & SM2320B & $\begin{array}{l}\text { ALKALINITY, CARBOINATIE } \\
\text { (AS CACO3) }\end{array}$ & 2 & MG/L & & 2 & 0.5 & u & U & \\
\hline $9 / 3 / 2003$ & EM00006769 & & GRAB & REG & EPA901.1 & AMERICIUM-241 & 19.6 & $\mathrm{pCi} / \mathrm{L}$ & 20.1 & & 32.3 & $U$ & U & \\
\hline $9 / 3 / 2003$ & EM00006769 & & GRAB & DUP & EPA901.1 & AMERICIUM-241 & -40.2 & $\mathrm{pCi} / \mathrm{L}$ & 30.3 & & 52.8 & $U$ & U & \\
\hline $9 / 3 / 2003$ & EM00006769 & & GRAB & REG & EPA901.1 & ANTIMONY-125 & -7.03 & $\mathrm{pCi} / \mathrm{L}$ & 12.5 & & 22.1 & $\mathrm{U}$ & $\mathrm{Uu}$ & \\
\hline $9 / 3 / 2003$ & EM00006769 & & GRAB & DUP & EPA901.1 & ANTIMONY-125 & -6.4 & $\mathrm{pCi} / \mathrm{L}$ & 12 & & 21.2 & $U$ & $\mathrm{U}$ & \\
\hline $9 / 3 / 2003$ & EM00006769 & & GRAB & REG & EPA200.7 & CALCIUM & 18200 & UG/L & & 12.2 & 12.2 & & & \\
\hline $9 / 3 / 2003$ & EM00006769 & & GRAB & LR1 & EPA200.7 & CALCIUM & 19055 & UG/L & & 12.2 & 12.2 & & & \\
\hline $9 / 3 / 2003$ & EM00006769 & & GRAB & REG & EERF C01 & CARBON-14 & 66.1 & $\mathrm{pCi} / \mathrm{L}$ & 108 & 177 & 177 & $\mathrm{U}$ & U & \\
\hline
\end{tabular}

B-17 
Table B-2. STATION ID: UE-1Q (continued)

\begin{tabular}{|c|c|c|c|c|c|c|c|c|c|c|c|c|c|}
\hline 9/3/2003 & EM00006769 & GRAB & REG & EPA901.1 & CERIUM-144 & -17.3 & $\mathrm{pCi} / \mathrm{L}$ & 26.4 & & 46.3 & $\mathrm{U}$ & $U$ & \\
\hline 9/3/2003 & EM00006769 & GRAB & DUP & EPA901.1 & CERIUM-144 & -10.6 & $\mathrm{pCi} / \mathrm{L}$ & 21.8 & & 37.5 & $U$ & U & \\
\hline 9/3/2003 & EM00006769 & GRAB & REG & EPA901.1 & CESIUM-134 & -2.21 & $p C i / L$ & 6.81 & & 11.9 & $U$ & $u$ & \\
\hline 9/3/2003 & EM00006769 & GRAB & DUP & EPA901.1 & CESIUM-134 & 1.74 & $\mathrm{pCi} / \mathrm{L}$ & 7.55 & & 12.6 & $U$ & $U$ & \\
\hline $9 / 3 / 2003$ & EM00006769 & GRAB & REG & EPA901.1 & CESIUM-137 & -6.3 & $p C i / L$ & 5.37 & & 9.83 & $U$ & U & \\
\hline 9/3/2003 & EM00006769 & GRAB & DUP & EPA901.1 & CESIUM-137 & -3.94 & $p C i / L$ & 5.38 & & 9.65 & $U$ & U & \\
\hline 9/3/2003 & EM00006769 & GRAB & REG & EPA300.0 & CHLORIDE & 12.1 & MG/L & & 5 & 0.25 & & & \\
\hline 9/3/2003 & EM00006769 & GRAB & REG & EPA901.1 & COBALT-60 & -4.7 & $\mathrm{pCi} / \mathrm{L}$ & 5.76 & & 10.8 & $U$ & $U$ & \\
\hline 9/3/2003 & EM00006769 & GRAB & DUP & EPA901.1 & COBALT-60 & 1.79 & $\mathrm{pCi} / \mathrm{L}$ & 6.15 & & 10.6 & $\mathrm{U}$ & U & \\
\hline 9/3/2003 & EM00006769 & GRAB & REG & EPA901.1 & EUROPIUM-152 & 21.9 & $\mathrm{pCi} / \mathrm{L}$ & 32 & & 52.7 & $U$ & $U$ & \\
\hline 9/3/2003 & EM00006769 & GRAB & DUP & EPA901.1 & EUROPIUM-152 & 0.778 & $\mathrm{pCi} / \mathrm{L}$ & 30.1 & & 53 & $\mathrm{U}$ & $U$ & \\
\hline 9/3/2003 & EM00006769 & GRAB & REG & EPA901.1 & EUROPIUM-154 & 21.9 & $\mathrm{pCi} / \mathrm{L}$ & 27.7 & & 45.1 & $\mathrm{U}$ & $U$ & \\
\hline 9/3/2003 & EM00006769 & GRAB & DUP & EPA901.1 & EUROPIUM-154 & -13 & $\mathrm{pCi} / \mathrm{L}$ & 30.7 & & 55.2 & $U$ & $U$ & \\
\hline 9/3/2003 & EM00006769 & GRAB & REG & EPA901.1 & EUROPIUM-155 & -2.16 & $\mathrm{pCi} / \mathrm{L}$ & 13 & & 22.7 & U & U & \\
\hline 9/3/2003 & EM00006769 & GRAB & DUP & EPA901.1 & EUROPIUM-155 & 2.07 & $\mathrm{pCi} / \mathrm{L}$ & 12.3 & & 20.8 & $U$ & $U$ & \\
\hline 9/3/2003 & EM00006769 & GRAB & REG & EPA300.0 & FLUORIDE & 0.36 & MG/L & & 0.25 & 0.25 & & & \\
\hline 9/3/2003 & EM00006769 & GRAB & DUP & EPA900.0 & GROSS ALPHA & 1.43 & $\mathrm{pCi} / \mathrm{L}$ & 0.817 & 1.33 & 1.33 & $\mathrm{~B}$ & & \\
\hline 9/3/2003 & EM00006769 & GRAB & REG & EPA900.0 & GROSS ALPHA & 1.6 & $\mathrm{pCi} / \mathrm{L}$ & 0.881 & 1.44 & 1.44 & $B$ & & \\
\hline 9/3/2003 & EM00006769 & GRAB & DUP & EPA900.0 & GROSS BETA & 7.43 & $p C i / L$ & 1.77 & 2.16 & 2.16 & & & \\
\hline 9/3/2003 & EM00006769 & GRAB & REG & EPA900.0 & GROSS BETA & 6.34 & $\mathrm{pCi} / \mathrm{L}$ & 1.67 & 2.31 & 2.31 & & & \\
\hline 9/3/2003 & EM00006769 & GRAB & REG & EPA901.1 & LEAD-212 & -2.53 & $\mathrm{pCi} / \mathrm{L}$ & 7.09 & & 12.4 & $U$ & $U$ & \\
\hline 9/3/2003 & EM00006769 & GRAB & DUP & EPA901.1 & LEAD-212 & 0.874 & $\mathrm{pCi} / \mathrm{L}$ & 8.7 & & 14.6 & $U$ & $U$ & \\
\hline 9/3/2003 & EM00006769 & GRAB & REG & EPA200.7 & MAGNESIUM & 14100 & UG/L & & 27.2 & 27.2 & & & \\
\hline 9/3/2003 & EM00006769 & GRAB & LR1 & EPA200.7 & MAGNESIUM & 14049 & UG/L & & 27.2 & 27.2 & & & \\
\hline 9/3/2003 & EM00006769 & GRAB & REG & ASTMD3972-90M & PLUTONIUM-238 & 0.00683 & $\mathrm{pCi} / \mathrm{L}$ & 0.0286 & & 0.0205 & $\mathrm{U}$ & U & \\
\hline 9/3/2003 & EM00006769 & GRAB & DUP & ASTMD3972-90M & PLUTONIUM-238 & -0.00743 & $\mathrm{pCi} / \mathrm{L}$ & 0.0357 & & 0.0569 & U & U & \\
\hline 9/3/2003 & EM00006769 & GRAB & DUP & ASTMD3972-90M & PLUTONIUM-239/240 & 0.00743 & $\mathrm{pCi} / \mathrm{L}$ & 0.0357 & & 0.0568 & $\mathrm{U}$ & 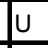 & \\
\hline 9/3/2003 & EM00006769 & GRAB & REG & ASTMD3972-90M & PLUTONIUM-239/240 & -0.00492 & $\mathrm{pCi} / \mathrm{L}$ & 0.0286 & & 0.0474 & $\mathrm{U}$ & U & \\
\hline 9/3/2003 & EM000066769 & GRAB & REG & EPA200.7 & POTASSIUM & 8550 & UG/L & & 430 & 430 & & & \\
\hline 9/3/2003 & EM00006769 & GRAB & LR1 & EPA200.7 & POTASSIUM & 8287 & UG/L & & 430 & 430 & & & \\
\hline 9/3/2003 & EM00006769 & GRAB & REG & EPA901.1 & POTASSIUM-40 & -0.576 & $\mathrm{pCi} / \mathrm{L}$ & 83 & & 143 & $\mathrm{U}$ & U & \\
\hline 9/3/2003 & EM00006769 & GRAB & DUP & EPA901.1 & POTASSIUM-40 & 64.8 & $p C i / L$ & 122 & & 203 & U & U & \\
\hline 9/3/2003 & EM00006769 & GRAB & REG & EPA901.1 & PROMETHIUM-144 & 0.743 & $\mathrm{pCi} / \mathrm{L}$ & 6.24 & & 10.6 & $\mathrm{U}$ & $U$ & \\
\hline 9/3/2003 & EM00006769 & GRAB & DUP & EPA901.1 & PROMETHIUM-144 & 3.32 & $\mathrm{pCi} / \mathrm{L}$ & 5.52 & & 9.14 & $U$ & U & \\
\hline
\end{tabular}

B-18 
Table B-2. STATION ID: UE-1Q (continued)

\begin{tabular}{|c|c|c|c|c|c|c|c|c|c|c|c|c|c|c|}
\hline $9 / 3 / 2003$ & EM00006769 & & GRAB & REG & EPA901.1 & PROMETHIUM-146 & 0.0534 & $\mathrm{pCi} / \mathrm{L}$ & 5.6 & & $9.69 \mathrm{U}$ & $\bar{U}$ & $\mathrm{U}$ & \\
\hline 9/3/2003 & EM00006769 & & GRAB & DUP & EPA901.1 & PROMETHIUM-146 & 0 & $\mathrm{pCi} / \mathrm{L}$ & 5.86 & & $10.1 \mathrm{U}$ & U & $\mathrm{U}$ & \\
\hline 9/3/2003 & EM00006769 & & GRAB & REG & EPA901.1 & RUTHENIUM-106 & 26.8 & $\mathrm{pCi} / \mathrm{L}$ & 47.5 & & $79 \mid u$ & U & U & \\
\hline 9/3/2003 & EM00006769 & & GRAB & DUP & EPA901.1 & RUTHENIUM-106 & 10.7 & $\mathrm{pCi} / \mathrm{L}$ & 43.7 & & $74.5 \mathrm{U}$ & $U$ & $\mathrm{U}$ & \\
\hline 9/3/2003 & EM00006769 & & GRAB & REG & EPA200.7 & SILICON & 3670 & UG/L & & 17.8 & 17.8 & & & \\
\hline 9/3/2003 & EM00006769 & & GRAB & LR1 & EPA200.7 & SILICON & 3672 & UG/L & & 17.8 & 17.8 & & & \\
\hline 9/3/2003 & EM00006769 & & GRAB & REG & EPA200.7 & SODIUM & 43500 & UG/L & & 22.6 & 22.6 & & & \\
\hline 9/3/2003 & EM00006769 & & GRAB & LR1 & EPA200.7 & SODIUM & 43332 & UG/L & & 22.6 & 22.6 & & & \\
\hline 9/3/2003 & EM00006769 & & GRAB & REG & EPA300.0 & SULFATE (AS SO4) & 25.9 & MG/L & & 5 & 0.25 & & & \\
\hline 9/3/2003 & EM000066769 & & GRAB & DUP & DOE RP550 & TECHNETIUM-99 & 3.92 & $\mathrm{pCi} / \mathrm{L}$ & 3.77 & 6.08 & $6.08 \mathrm{U}$ & $U$ & $\mathrm{U}$ & \\
\hline 9/3/2003 & EM00006769 & & GRAB & REG & DOE RP550 & TECHNETIUM-99 & 3.13 & $\mathrm{pCi} / \mathrm{L}$ & 3.74 & 6.09 & $6.09 \mathrm{U}$ & $U$ & $\mathrm{U}$ & \\
\hline 9/3/2003 & EM00006769 & & GRAB & REG & EPA901.1 & THORIUM-234 & 8.6 & $\mathrm{pCi} / \mathrm{L}$ & 88.6 & & $150 \mathrm{U}$ & $U$ & $\mathrm{U}$ & \\
\hline 9/3/2003 & EM00006769 & & GRAB & DUP & EPA901.1 & THORIUM-234 & -69.3 & $\mathrm{pCi} / \mathrm{L}$ & 111 & & $188 \mathrm{U}$ & $U$ & $\mathrm{U}$ & \\
\hline 9/3/2003 & EM00006769 & & GRAB & REG & EPA160.1 & TOTAL DISSOLVED SOLIDS & 227 & MG/L & & 5 & 5 & & & \\
\hline 9/3/2003 & EM00006769 & & GRAB & REG & EPA906.0 & TRITIUM & -83.4 & $\mathrm{PCI} / \mathrm{L}$ & 145 & & $253 \mathrm{U}$ & U & $\mathrm{U}$ & \\
\hline 9/3/2003 & EM00006769 & & GRAB & REG & EPA901.1 & URANIUM-235 & 11.4 & $\mathrm{pCi} / \mathrm{L}$ & 28.1 & & 474 & $U$ & $\mathrm{U}$ & \\
\hline 9/3/2003 & EM00006769 & & GRAB & DUP & EPA901.1 & URANIUM-235 & -7.61 & $\mathrm{pCi} / \mathrm{L}$ & 28.6 & & \begin{tabular}{ll|l}
48.5 & $\mathrm{U}$ \\
\end{tabular} & $U$ & $\mathrm{U}$ & \\
\hline 9/3/2003 & EM00006769 & & GRAB & REG & EPA901.1 & YTTRIUM-88 & -1.5 & $\mathrm{pCi} / \mathrm{L}$ & 6.51 & & $11.5 \mathrm{U}$ & U & $\mathrm{U}$ & \\
\hline 9/3/2003 & EM00006769 & & GRAB & DUP & EPA901.1 & YTTRIUM-88 & 4.56 & $\mathrm{pCi} / \mathrm{L}$ & 6.4 & & $10.5 \mathrm{U}$ & U & $\mathrm{U}$ & \\
\hline 9/9/2003 & EMBESST001 & & GRAB & REG & EPA906.0 & TRITIUM & -140 & $\mathrm{PCI} / \mathrm{L}$ & 141 & & $251 \mathrm{U}$ & $U$ & $\mathrm{U}$ & \\
\hline $2 / 4 / 2004$ & EM00007326 & & EB & REG & EPA906.0 & TRITIUM & 430 & $\mathrm{PCI} / \mathrm{L}$ & 158 & & 235 & & $\mathrm{~J}$ & 7 \\
\hline $2 / 4 / 2004$ & EM00007327 & 2475 & FD & REG & EPA906.0 & TRITIUM & 403 & $\mathrm{PCI} / \mathrm{L}$ & 155 & & 233 & & $\mathrm{~J}$ & 7 \\
\hline $2 / 4 / 2004$ & EM00007328 & 2475 & GRAB & REG & EPA906.0 & TRITIUM & 347 & $\mathrm{PCI} / \mathrm{L}$ & 148 & & 225 & & $\mathrm{~J}$ & 7 \\
\hline $2 / 9 / 2005$ & EM00008639 & 2475 & GRAB & REG & EPA901.1 & ACTINIUM-228 & 4.84 & $\mathrm{PCI} / \mathrm{L}$ & 17 & 0 & $28.5 \mathrm{U}$ & $U$ & $\mathrm{U}$ & \\
\hline 2/9/2005 & EM00008639 & 2475 & GRAB & LR1 & EPA901.1 & ACTINIUM-228 & 0.363 & $\mathrm{PCI} / \mathrm{L}$ & 18.2 & 0 & $19.4 \mathrm{U}$ & $U$ & $\mathrm{U}$ & \\
\hline 2/9/2005 & EM00008639 & 2475 & GRAB & REG & SM2320B & $\begin{array}{l}\text { ALKALINITY, BICARBONATE } \\
\text { (AS CACO3) }\end{array}$ & 190 & MG/L & & 2 & 0.5 & & & \\
\hline 2/9/2005 & EM00008639 & 2475 & GRAB & REG & SM2320B & $\begin{array}{l}\text { ALKALINITY, CARBONATE } \\
\text { (AS CACO3) }\end{array}$ & 2 & MG/L & & 2 & $0.5 \mathrm{U}$ & U & $\mathrm{U}$ & \\
\hline 2/9/2005 & EM00008639 & 2475 & GRAB & REG & EPA901.1 & AMERICIUM-241 & 8.39 & $\mathrm{PCI} / \mathrm{L}$ & 19.2 & 0 & $33.8 \mathrm{U}$ & $U$ & $\mathrm{U}$ & \\
\hline $2 / 9 / 2005$ & EM00008639 & 2475 & GRAB & LR1 & EPA901.1 & AMERICIUM-241 & -11.2 & $\mathrm{PCI} / \mathrm{L}$ & 28 & 0 & \begin{tabular}{ll|l}
30.3 & $\mathrm{U}$ \\
\end{tabular} & $U$ & $\mathrm{U}$ & \\
\hline 2/9/2005 & EM00008639 & 2475 & GRAB & REG & EPA901.1 & ANTIMONY-125 & 4.71 & $\mathrm{PCI} / \mathrm{L}$ & 9.34 & 0 & $17.4 \mathrm{U}$ & $U$ & $U$ & \\
\hline 2/9/2005 & EM00008639 & 2475 & GRAB & LR1 & EPA901.1 & ANTIMONY-125 & 2.16 & $\mathrm{PCI} / \mathrm{L}$ & 7.28 & 0 & $12.5 \mathrm{U}$ & U & $U$ & \\
\hline 2/9/2005 & EM00008639 & 2475 & GRAB & REG & EPA200.7 & CALCIUM & 22900 & UG/L & & 46.8 & \begin{tabular}{l|l}
7.8 \\
\end{tabular} & & & \\
\hline 2/9/2005 & EM00008639 & 2475 & GRAB & LR1 & EPA200.7 & CALCIUM & 22775 & UG/L & & 46.8 & 7.8 & & & \\
\hline $2 / 9 / 2005$ & EM00008639 & 2475 & GRAB & REG & EERF C01 & CARBON-14 & -60.9 & $\mathrm{PCI} / \mathrm{L}$ & 106 & 0 & $186 \mathrm{U}$ & $U$ & $\mathrm{U}$ & \\
\hline
\end{tabular}

B-19 
Table B-2. STATION ID: UE-1Q (continued)

\begin{tabular}{|c|c|c|c|c|c|c|c|c|c|c|c|c|c|c|}
\hline $2 / 9 / 2005$ & EM00008639 & 2475 & GRAB & LR1 & EERF C01 & CARBON-14 & -9.52 & $\mathrm{PCI} / \mathrm{L}$ & 110 & 0 & 189 & $U$ & $U$ & \\
\hline 2/9/2005 & EM00008639 & 2475 & GRAB & REG & EPA901.1 & CERIUM-144 & 22.6 & $\mathrm{PCI} / \mathrm{L}$ & 17 & 0 & 38.4 & $u$ & u & \\
\hline 2/9/2005 & EM00008639 & 2475 & GRAB & LR1 & EPA901.1 & CERIUM-144 & -6.05 & $\mathrm{PCI} / \mathrm{L}$ & 18.1 & 0 & 30.5 & $U$ & $U$ & \\
\hline 2/9/2005 & EM00008639 & 2475 & GRAB & REG & EPA901.1 & CESIUM-134 & 0.19 & $\mathrm{PCI} / \mathrm{L}$ & 4.26 & 0 & 6.74 & $U$ & $U$ & \\
\hline 2/9/2005 & EM00008639 & 2475 & GRAB & LR1 & EPA901.1 & CESIUM-134 & 1.63 & $\mathrm{PCI} / \mathrm{L}$ & 3.32 & 0 & 5.74 & $u$ & u & \\
\hline 2/9/2005 & EM00008639 & 2475 & GRAB & REG & EPA901.1 & CESIUM-137 & -0.686 & $\mathrm{PCI} / \mathrm{L}$ & 3.73 & 0 & 6.5 & $U$ & $\mathrm{U}$ & \\
\hline 2/9/2005 & EM00008639 & 2475 & GRAB & LR1 & EPA901.1 & CESIUM-137 & -0.92 & $\mathrm{PCI} / \mathrm{L}$ & 2.69 & 0 & 4.67 & $U$ & $U$ & \\
\hline 2/9/2005 & EM00008639 & 2475 & GRAB & REG & EPA300.0 & CHLORIDE & 18.3 & MG/L & & 2.5 & 0.25 & & & \\
\hline 2/9/2005 & EM00008639 & 2475 & GRAB & REG & EPA901.1 & COBALT-60 & 0.743 & $\mathrm{PCI} / \mathrm{L}$ & 8.44 & 0 & 7.58 & $U$ & $U$ & \\
\hline 2/9/2005 & EM00008639 & 2475 & GRAB & LR1 & EPA901.1 & COBALT-60 & 0.229 & $\mathrm{PCI} / \mathrm{L}$ & 2.75 & 0 & 4.93 & $U$ & $U$ & \\
\hline 2/9/2005 & EM00008639 & 2475 & GRAB & REG & EPA901.1 & EUROPIUM-152 & -8.52 & $\mathrm{PCI} / \mathrm{L}$ & 9.27 & 0 & 15.3 & $U$ & $U$ & \\
\hline 2/9/2005 & EM00008639 & 2475 & GRAB & LR1 & EPA901.1 & EUROPIUM-152 & 3.89 & $\mathrm{PCI} / \mathrm{L}$ & 10.1 & 0 & 13.4 & $U$ & $U$ & \\
\hline 2/9/2005 & EM00008639 & 2475 & GRAB & REG & EPA901.1 & EUROPIUM-154 & 2.82 & $\mathrm{PCI} / \mathrm{L}$ & 11.3 & 0 & 22 & $U$ & $U$ & \\
\hline 2/9/2005 & EM00008639 & 2475 & GRAB & LR1 & EPA901.1 & EUROPIUM-154 & 3.6 & $\mathrm{PCI} / \mathrm{L}$ & 6.88 & 0 & 13.1 & $U$ & $U$ & \\
\hline 2/9/2005 & EM00008639 & 2475 & GRAB & REG & EPA901.1 & EUROPIUM-155 & 0.576 & $\mathrm{PCI} / \mathrm{L}$ & 11.6 & 0 & 19.7 & $U$ & $U$ & \\
\hline 2/9/2005 & EM00008639 & 2475 & GRAB & LR1 & EPA901.1 & EUROPIUM-155 & 8.37 & $\mathrm{PCI} / \mathrm{L}$ & 10.6 & 0 & 16 & $U$ & $\mathrm{U}$ & \\
\hline 2/9/2005 & EM00008639 & 2475 & GRAB & REG & EPA300.0 & FLUORIDE & 0.48 & $\mathrm{MG} / \mathrm{L}$ & & 0.25 & 0.25 & & & \\
\hline 2/9/2005 & EM00008638 & 2475 & $F D$ & REG & EPA900.0 & GROSS ALPHA & 5.72 & $\mathrm{PCI} / \mathrm{L}$ & 1.42 & 0 & 1.27 & & & \\
\hline 2/9/2005 & EM00008639 & 2475 & GRAB & REG & EPA900.0 & GROSS ALPHA & 8.06 & $\mathrm{PCI} / \mathrm{L}$ & 1.69 & 0 & 1.32 & & & \\
\hline 2/9/2005 & EM00008639 & 2475 & GRAB & LR1 & EPA900.0 & GROSS ALPHA & 6.26 & $\mathrm{PCI} / \mathrm{L}$ & 1.49 & 0 & 1.25 & & & \\
\hline 2/9/2005 & EM00008638 & 2475 & $F D$ & REG & EPA900.0 & GROSS BETA & 7.02 & $\mathrm{PCI} / \mathrm{L}$ & 0.907 & 0 & 0.973 & & & \\
\hline 2/9/2005 & EM00008639 & 2475 & GRAB & REG & EPA900.0 & GROSS BETA & 7.27 & $\mathrm{PCI} / \mathrm{L}$ & 0.902 & 0 & 0.872 & & & \\
\hline 2/9/2005 & EM00008639 & 2475 & GRAB & LR1 & EPA900.0 & GROSS BETA & 8.43 & $\mathrm{PCI} / \mathrm{L}$ & 1.01 & 0 & 1.09 & & & \\
\hline 2/9/2005 & EM00008639 & 2475 & GRAB & REG & EPA901.1 & LEAD-212 & 0.952 & $\mathrm{PCI} / \mathrm{L}$ & 10.2 & 0 & 9.87 & $U$ & $U$ & \\
\hline 2/9/2005 & EM00008639 & 2475 & GRAB & LR1 & EPA901.1 & LEAD-212 & 10.6 & $\mathrm{PCI} / \mathrm{L}$ & 5.3 & 0 & 9.42 & $x$ & $R$ & LA \\
\hline 2/9/2005 & EM00008639 & 2475 & GRAB & REG & EPA200.7 & MAGNESIUM & 13200 & UG/L & & 34.2 & 5.7 & & & \\
\hline 2/9/2005 & EM00008639 & 2475 & GRAB & LR1 & EPA200.7 & MAGNESIUM & 13070 & UG/L & & 34.2 & 5.7 & & & \\
\hline 2/9/2005 & EM00008639 & 2475 & GRAB & REG & EPA200.7 & POTASSIUM & 10900 & UG/L & & 50.4 & 8.4 & & & \\
\hline 2/9/2005 & EM00008639 & 2475 & GRAB & LR1 & EPA200.7 & POTASSIUM & 10790 & UG/L & & 50.4 & 8.4 & & & \\
\hline 2/9/2005 & EM00008639 & 2475 & GRAB & REG & EPA901.1 & POTASSIUM-40 & 25 & $\mathrm{PCI} / \mathrm{L}$ & 70.1 & 0 & 60.1 & $U$ & $U$ & \\
\hline $2 / 9 / 2005$ & EM00008639 & 2475 & GRAB & LR1 & EPA901.1 & POTASSIUM-40 & 71.7 & $\mathrm{PCI} / \mathrm{L}$ & 35.6 & 0 & 71.4 & $x$ & $R$ & LA \\
\hline $2 / 9 / 2005$ & EM00008639 & 2475 & GRAB & REG & EPA901.1 & PROMETHIUM-144 & 1.22 & $\mathrm{PCI} / \mathrm{L}$ & 3.77 & 0 & 6.88 & $U$ & $\mathrm{U}$ & \\
\hline 2/9/2005 & EM00008639 & 2475 & GRAB & LR1 & EPA901.1 & PROMETHIUM-144 & 2.55 & $\mathrm{PCI} / \mathrm{L}$ & 2.34 & 0 & 4.39 & $U$ & $U$ & \\
\hline 2/9/2005 & EM00008639 & 2475 & GRAB & REG & EPA901.1 & PROMETHIUM-146 & 0.851 & $\mathrm{PCI} / \mathrm{L}$ & 4.13 & 0 & 7.56 & $U$ & $\mathrm{U}$ & \\
\hline 2/9/2005 & EM00008639 & 2475 & GRAB & LR1 & EPA901.1 & PROMETHIUM-146 & 1.57 & $\mathrm{PCI} / \mathrm{L}$ & 3.49 & 0 & 6.03 & $U$ & u & \\
\hline
\end{tabular}


Table B-2. STATION ID: UE-1Q (continued)

\begin{tabular}{|c|c|c|c|c|c|c|c|c|c|c|c|c|c|c|}
\hline $2 / 9 / 2005$ & EM00008639 & 2475 & GRAB & REG & EPA901.1 & EUROPIUM-155 & 0.576 & $\mathrm{PCI} / \mathrm{L}$ & 11.6 & 0 & 19.7 & $\mathrm{U}$ & $\mathrm{U}$ & \\
\hline 2/9/2005 & EM00008639 & 2475 & GRAB & LR1 & EPA901.1 & EUROPIUM-155 & 8.37 & $\mathrm{PCI} / \mathrm{L}$ & 10.6 & 0 & 16 & u & U & \\
\hline 2/9/2005 & EM00008639 & 2475 & GRAB & REG & EPA300.0 & FLUORIDE & 0.48 & $\mathrm{MG} / \mathrm{L}$ & & 0.25 & 0.25 & & & \\
\hline 2/9/2005 & EM00008638 & 2475 & FD & REG & EPA900.0 & GROSS ALPHA & 5.72 & $\mathrm{PCI} / \mathrm{L}$ & 1.42 & 0 & 1.27 & & & \\
\hline 2/9/2005 & EM00008639 & 2475 & GRAB & REG & EPA900.0 & GROSS ALPHA & 8.06 & $\mathrm{PCI} / \mathrm{L}$ & 1.69 & 0 & 1.32 & & & \\
\hline 2/9/2005 & EM00008639 & 2475 & GRAB & LR1 & EPA900.0 & GROSS ALPHA & 6.26 & $\mathrm{PCI} / \mathrm{L}$ & 1.49 & 0 & 1.25 & & & \\
\hline 2/9/2005 & EM00008638 & 2475 & FD & REG & EPA900.0 & GROSS BETA & 7.02 & $\mathrm{PCI} / \mathrm{L}$ & 0.907 & 0 & 0.973 & & & \\
\hline 2/9/2005 & EM00008639 & 2475 & GRAB & REG & EPA900.0 & GROSS BETA & 7.27 & $\mathrm{PCI} / \mathrm{L}$ & 0.902 & 0 & 0.872 & & & \\
\hline 2/9/2005 & EM00008639 & 2475 & GRAB & LR1 & EPA900.0 & GROSS BETA & 8.43 & $\mathrm{PCI} / \mathrm{L}$ & 1.01 & 0 & 1.09 & & & \\
\hline 2/9/2005 & EM00008639 & 2475 & GRAB & REG & EPA901.1 & LEAD-212 & 0.952 & $\mathrm{PCI} / \mathrm{L}$ & 10.2 & 0 & 9.87 & $\mathrm{U}$ & $\mathrm{U}$ & \\
\hline 2/9/2005 & EM00008639 & 2475 & GRAB & LR1 & EPA901.1 & LEAD-212 & 10.6 & $\mathrm{PCI} / \mathrm{L}$ & 5.3 & 0 & 9.42 & $x$ & $R$ & LA \\
\hline 2/9/2005 & EM00008639 & 2475 & GRAB & REG & EPA200.7 & MAGNESIUM & 13200 & UG/L & & 34.2 & 5.7 & & & \\
\hline 2/9/2005 & EM00008639 & 2475 & GRAB & LR1 & EPA200.7 & MAGNESIUM & 13070 & UG/L & & 34.2 & 5.7 & & & \\
\hline 2/9/2005 & EM00008639 & 2475 & GRAB & REG & EPA200.7 & POTASSIUM & 10900 & UG/L & & 50.4 & 8.4 & & & \\
\hline 2/9/2005 & EM00008639 & 2475 & GRAB & LR1 & EPA200.7 & POTASSIUM & 10790 & UG/L & & 50.4 & 8.4 & & & \\
\hline $2 / 9 / 2005$ & EM00008639 & 2475 & GRAB & REG & EPA901.1 & POTASSIUM-40 & 25 & $\mathrm{PCI} / \mathrm{L}$ & 70.1 & 0 & 60.1 & $U$ & $\mathrm{U}$ & \\
\hline 2/9/2005 & EM00008639 & 2475 & GRAB & LR1 & EPA901.1 & POTASSIUM-40 & 71.7 & $\mathrm{PCI} / \mathrm{L}$ & 35.6 & 0 & 71.4 & $x$ & $R$ & LA \\
\hline 2/9/2005 & EM00008639 & 2475 & GRAB & REG & EPA901.1 & PROMETHIUM-144 & 1.22 & $\mathrm{PCI} / \mathrm{L}$ & 3.77 & 0 & 6.88 & $U$ & 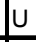 & \\
\hline 2/9/2005 & EM00008639 & 2475 & GRAB & LR1 & EPA901.1 & PROMETHIUM-144 & 2.55 & $\mathrm{PCI} / \mathrm{L}$ & 2.34 & 0 & 4.39 & $\mathrm{U}$ & $u$ & \\
\hline 2/9/2005 & EM00008639 & 2475 & GRAB & REG & EPA901.1 & PROMETHIUM-146 & 0.851 & $\mathrm{PCI} / \mathrm{L}$ & 4.13 & 0 & 7.56 & $\mathrm{U}$ & U & \\
\hline 2/9/2005 & EM00008639 & 2475 & GRAB & LR1 & EPA901.1 & PROMETHIUM-146 & 1.57 & $\mathrm{PCI} / \mathrm{L}$ & 3.49 & 0 & 6.03 & U & $\mathrm{U}$ & \\
\hline
\end{tabular}




\section{Notes:}

Data extracted from Bechtel Environmental Integrated Data Management System (BEIDMS) Version 3.8 on March 8, 2006.

Field names modified and reformatted as needed for clarity.

Top Depth is the groundwater sample collection depth in feet.

\section{Acronyms, Abbreviations, and Codes}

Sample Type

$\mathrm{N}$

GRAB

FD

EB

Analysis Code

DUP

LR1

REG

Units

MG/L

$P C i / L$

UG/L
Normal sample (same as grab)

Normal grab sample

Field Duplicate

Equipment Blank

Duplicate Analysis, same as LR1

ab replicate analysis

Regular analysis

Milligrams per liter

PicoCuries per liter

Micrograms per liter
Lab and review qualification codes

B Compound was also detected in method blank.

$\mathrm{J}$ Result is less than the contractually required detection

limit (estimated).

JN Analyte has been tentatively identified; associated

numerical value is estimated.

$\mathrm{N} \quad \mathrm{I}$ : Spiked recovery not within control limits; $\mathrm{O}$

presumptive evidence of presence.

QCD Quality Control Deficiency

$\mathrm{R} \quad$ Data rejected.

$U$ Result is less than minimum detectable activity.

$X \quad$ Other flag which must be defined in case narrative.

Code 1 qualifier

2 Sample preservation problem

$7 \quad$ Lab blanks

$8 \quad$ Matrix spike

14 Other

25 ICS recovery

I Matrix Interference

LA Low abundance

NVP No valid peak 


\section{DISTRIBUTION}

U.S. Department of Energy

1 copy

National Nuclear Security Administration

Nevada Site Office

Technical Library

P.O. Box 98518, M/S 505

Las Vegas, NV 89193-8518

U.S. Department of Energy

1 сору

National Nuclear Security Administration

Nevada Site Office

Public Reading Facility

c/o Nuclear Testing Archive

P.O. Box 98521, M/S 400

Las Vegas, NV 89193-8521

U.S. Department of Energy

1 electronic copy

Office of Scientific and Technical Information

P.O. Box 62

Oak Ridge, TN 37831-0062

E. Frank Di Sanza, Federal Project Director

1 сору

Office of Environmental Management

Waste Management Project

U.S. Department of Energy

National Nuclear Security Administration

Nevada Site Office

P.O. Box 98518

Las Vegas, NV 89193-8518

Jhon Carilli, LLW Federal Sub-Project Director

4 copies

Office of Environmental Management

Waste Management Project

U.S. Department of Energy

National Nuclear Security Administration

Nevada Site Office

P.O. Box 98518, M/S 505

Las Vegas, NV 89193-8518

James Cebe

Office of Environmental Management

1 copy

Waste Management Project

U.S. Department of Energy

National Nuclear Security Administration

Nevada Site Office

P.O. Box 98518, M/S 505

Las Vegas, NV 89193-8518 
Bruce M. Crowe

1 copy

Stoller-Navarro Joint Venture/

Battelle Memorial Institute

U.S. Department of Energy

National Nuclear Security Administration

Nevada Site Office

P.O. Box 98518, M/S 505

Las Vegas, NV 89193-8518

Terry Brooker

1 copy

National Security Technologies, LLC

P.O. Box 98521, M/S NLV022

Las Vegas, NV 89193-8521

Lloyd Desotell

1 copy

National Security Technologies, LLC

P.O. Box 98521, M/S NLV083

Las Vegas, NV 89193-8521

Steve Nacht

National Security Technologies, LLC

1 copy

P.O. Box 98521, M/S NLV083

Las Vegas, NV 89193-8521

Radioactive Waste Program

1 copy

National Security Technologies, LLC

P.O. Box 98521, M/S NLV083

Las Vegas, NV 89193-8521

Stuart Rawlinson

National Security Technologies, LLC

P.O. Box 98521, M/S NTS416

Las Vegas, NV 89193-8521

Gregory J. Shott

National Security Technologies, LLC

P.O. Box 98521, M/S NLV083

Las Vegas, NV 89193-8521

Denise Wieland

1 copy

National Security Technologies, LLC

P.O. Box 98521, M/S NTS416

Las Vegas, NV 89193-8521 
Vefa Yucel

1 copy

National Security Technologies, LLC

P.O. Box 98521, M/S NLV083

Las Vegas, NV 89193-8521

Environmental Management Library

1 copy

National Security Technologies, LLC

1 electronic copy

P.O. Box 98518, M/S NLV094

Las Vegas, NV 89193-8521 
This Page Intentionally Left Blank 